\title{
Maturation of GABAergic signaling during brainstem development
}

\author{
Dissertation \\ zur Erlangung des Doktorgrades \\ der Mathematisch-Naturwissenschaftlichen Fakultäten \\ der Georg-August-Universität zu Göttingen
}

\author{
vorgelegt von \\ Evangelia Tantalaki \\ aus Thessaloniki, Griechenland
}

Göttingen 2007 
D7

Referent: Prof. Dr. Ralf Heinrich

Institute for Zoology, Anthropology and Developmental Biology

Department of Neurobiology

Korreferent: Prof. Dr. Erwin Neher

Max Planck Institute for biophysical Chemistry

Tag der mündlichen Prüfung: 
To Christodoulia \& Maria Ilia 



\section{Table of contents}

Table of contents .. $\mathrm{i}$

1.1 G protein coupled receptors (GPCRs) .................................................

1.1.1 Evolution \& structural classification of GPCRs .....................................2

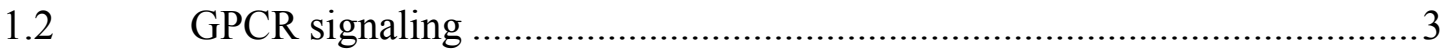

1.2.1 GPCR signaling specificity through $\mathrm{G}$ protein variability.........................4

1.2.2 GPCR signaling specificity through the complexity of the GPCRs............5

1.2.3 GPCR signaling specificity through ligands heterogeneity ........................5

1.2.4 GPCR signaling specificity in a cell- or tissue-dependent manner...............7

1.2.5 GPCR signaling specificity through GIPs ........................................

1.2.5.1 Specificity arising within membrane microdomains ................................ 8

1.2.5.2 Association with other signaling or structural proteins ............................ 8

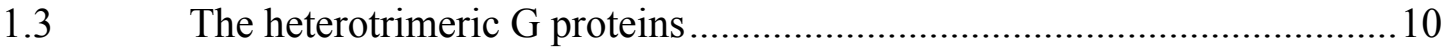

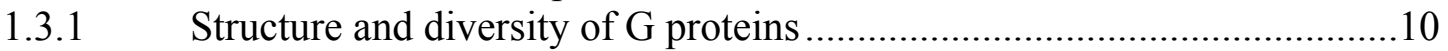

1.3.1.1 The complexity of the stimulatory $\mathrm{G}\left(\mathrm{G} \alpha_{\mathrm{s}}\right)$ protein ............................... 13

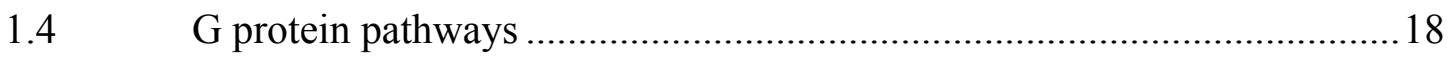

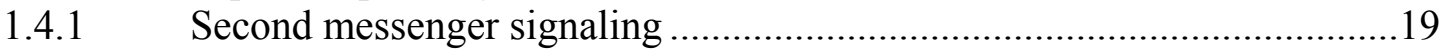

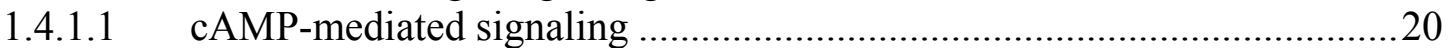

1.4.1.2 Other second messenger signaling pathways........................................20

1.4.2 Non second messenger signaling cascades/ MAPK .................................21

1.4.3 Cross-talk between GPCR pathways ......................................................21

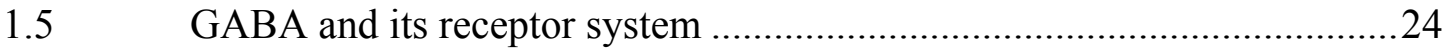

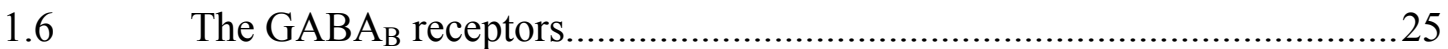

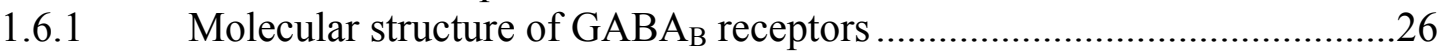

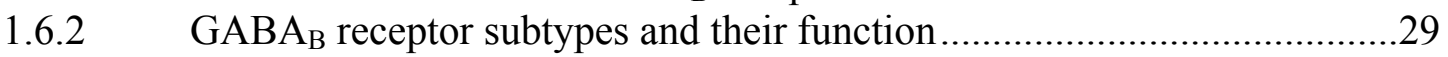

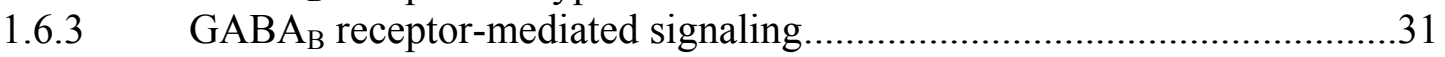

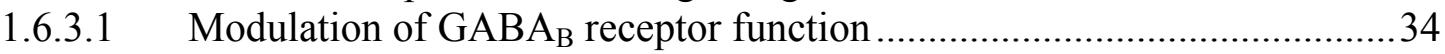

1.7 Changes in the distribution of the GABAergic system............................36

1.7.1 Distribution of $\mathrm{GABA}_{\mathrm{A}}$ receptor variants during brain development.........36

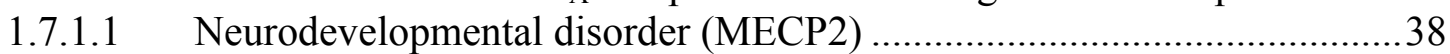

1.7.2 Distribution of $\mathrm{GABA}_{\mathrm{B}}$ receptor variants during brain development.........39

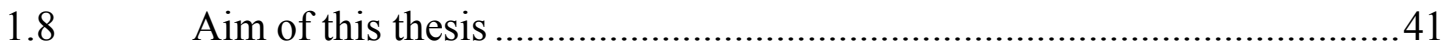

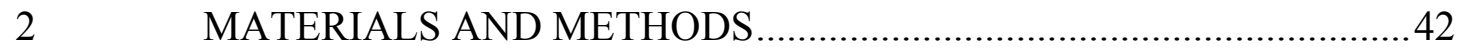

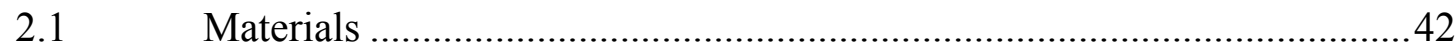

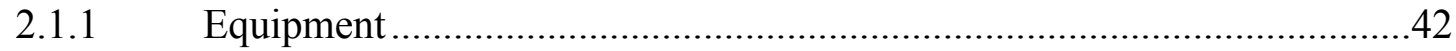

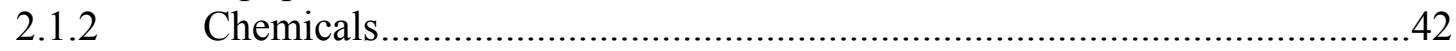




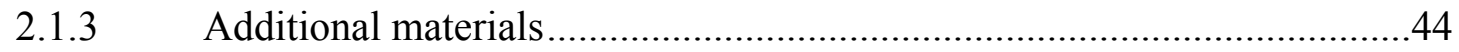

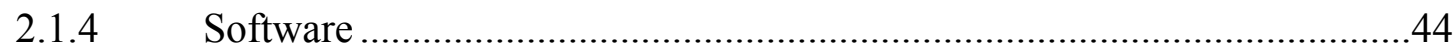

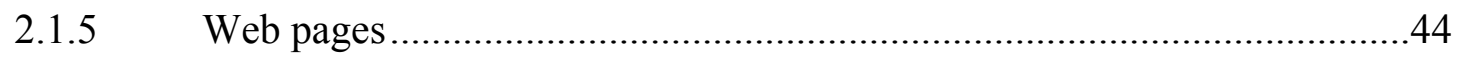

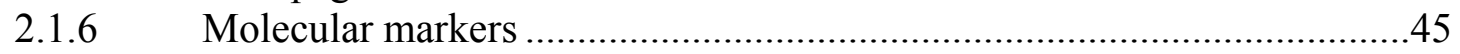

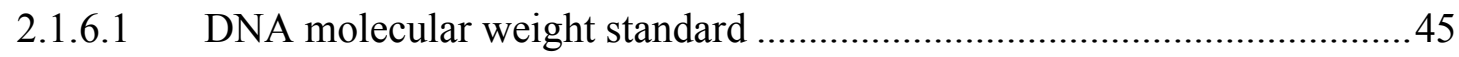

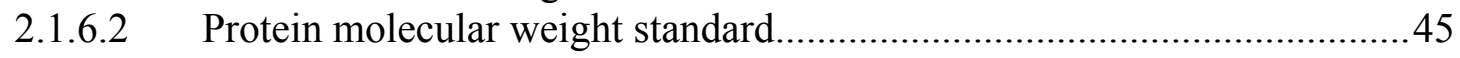

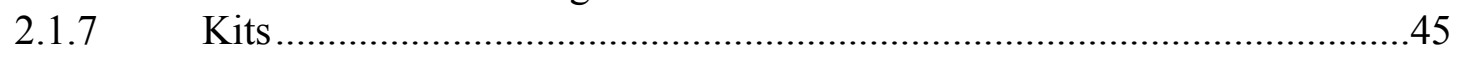

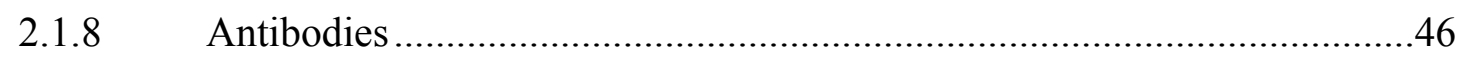

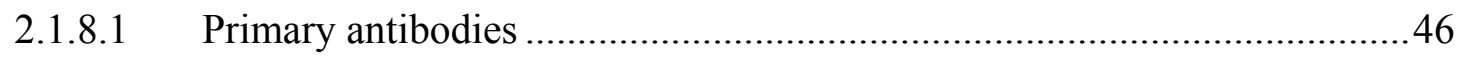

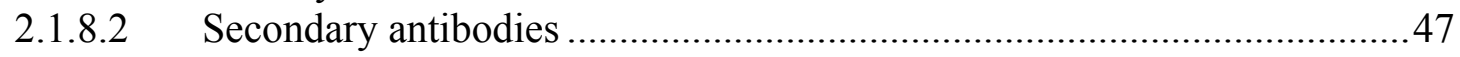

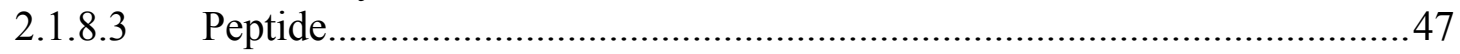

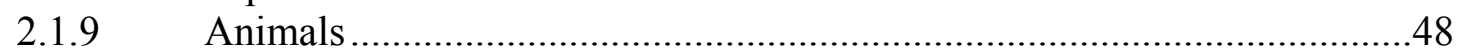

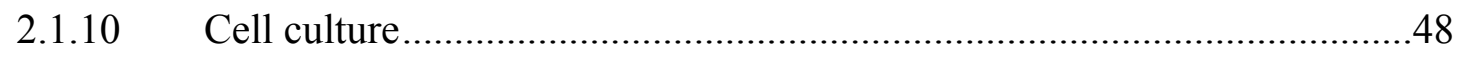

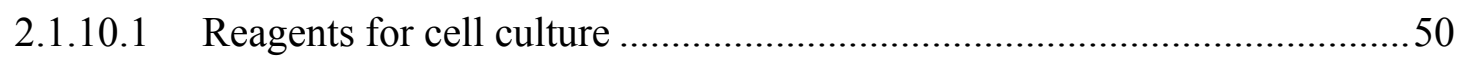

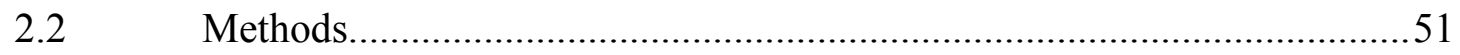

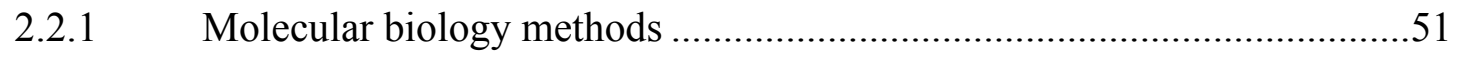

2.2.1.1 Isolation of total RNA from mice brainstem ......................................51

2.2.1.2 Reverse transcription-polymerase chain reaction (RT-PCR) ...................52

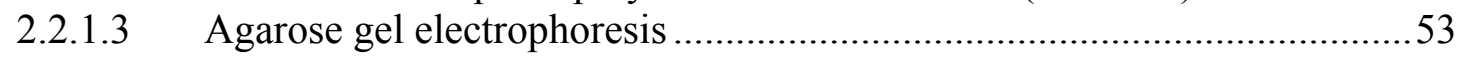

2.2.1.4 Extraction of the DNA fragments from agarose gels..............................54

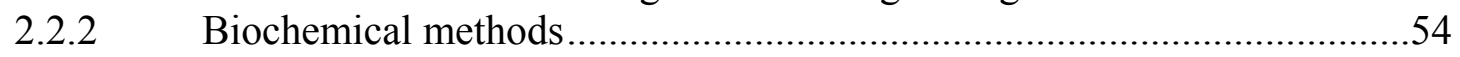

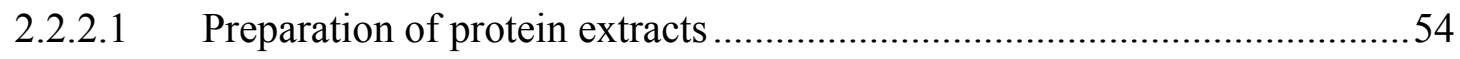

2.2.2.2 Determination of protein concentration ...............................................55

2.2.2.3 Sodium Dodecyl Sulfate-Polyacrylamide gel Electrophoresis (SDS-

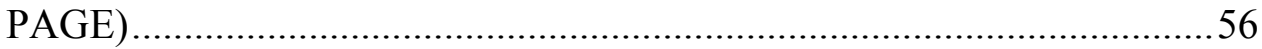

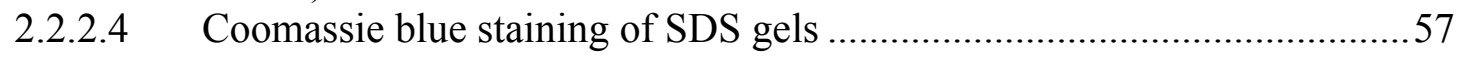

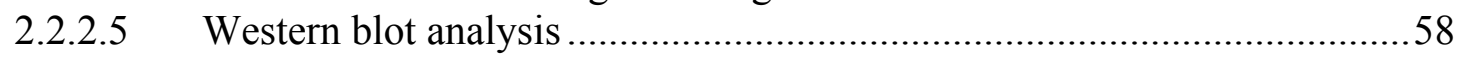

2.2.2.6 Staining membranes with Ponceau S ...................................................5

2.2.2.7 Immunodetection of proteins in western blot using horse-radisch peroxidase-conjugated antibodies....................................................59

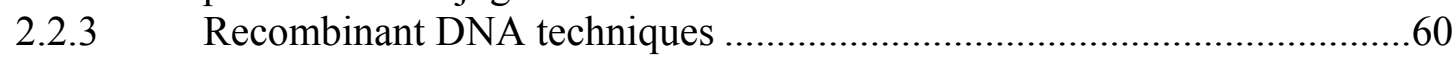

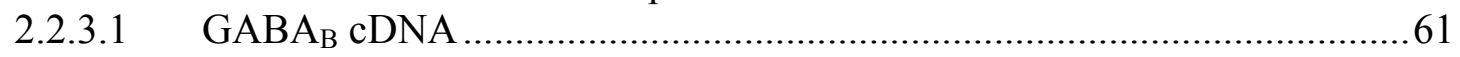

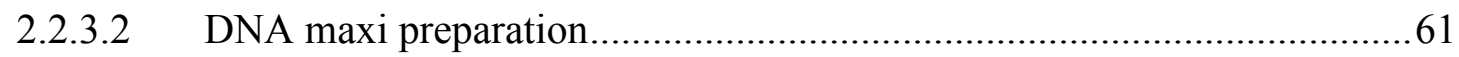

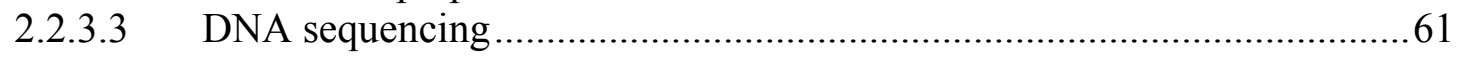

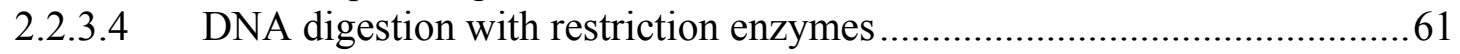

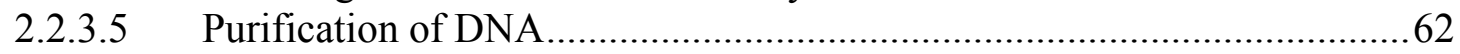

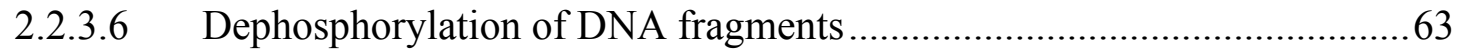

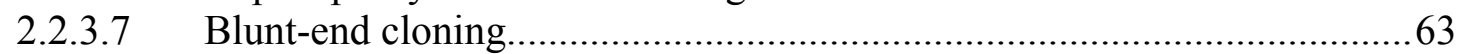

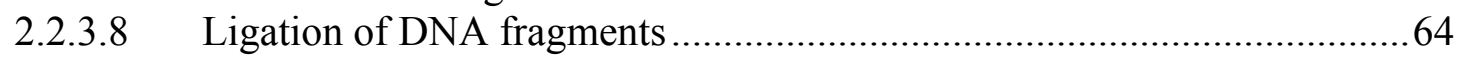

2.2.3.9 Transformation of competent cells by electroporation .............................66

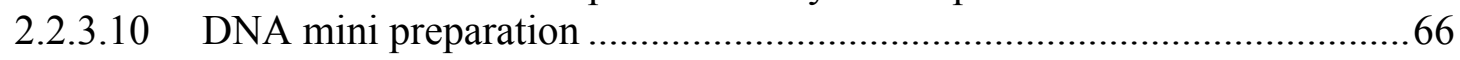

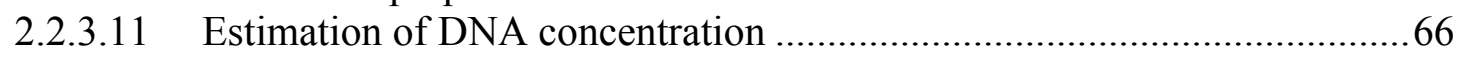

2.2.4 Culture of HEK293 cells stably transfected with $\mathrm{GABA}_{\mathrm{B}} \mathrm{R} 1 \alpha$ and

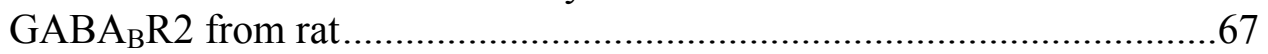

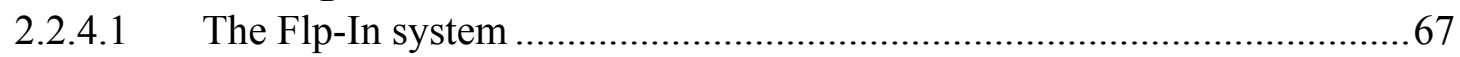

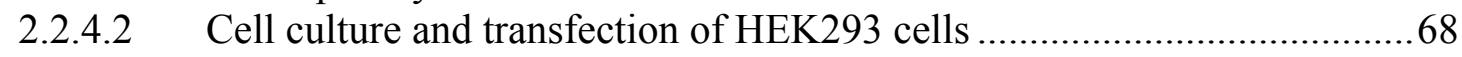

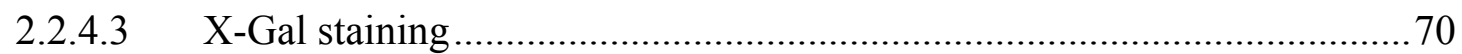

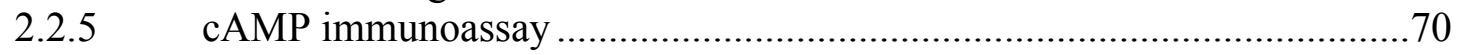

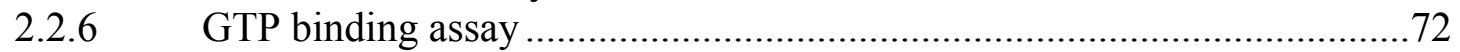


2.2.6.1 Immunoprecipitation of $\left[{ }^{35} \mathrm{~S}\right] \mathrm{GTP} \gamma \mathrm{S}$-labelled $\mathrm{G}$ proteins........................72

2.2.6.2 Immunoprecipitation of Eu-GTP-labelled G proteins. ..............................73

3 RESULTS

3.1 Cloning and expression of $\mathrm{GABA}_{\mathrm{B}} \mathrm{R} 1 \mathrm{a}$ and $\mathrm{GABA}_{\mathrm{B}} \mathrm{R} 2$ from rat in HEK 293 cells .................................................................................... 74

3.2 Ontogenetic development of the $\mathrm{GABA}_{\mathrm{B}}$ receptor in mouse brain ............75

3.3 Changes in the $\mathrm{GABA}_{\mathrm{B}}$ receptor signaling in the developing mouse brainstem.....

3.4 Maturation of the mouse brain is associated with a differential expression of variants of $\mathrm{G}$ protein alpha subunits

3.4.1 Distribution of the $\mathrm{G \alpha}_{\mathrm{i} / \mathrm{o}}$ and $\mathrm{G} \alpha_{\mathrm{q} / 11}$ proteins in adult and P0 mouse

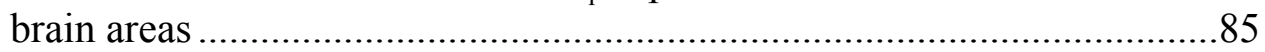

3.4.2 Distribution of the $\mathrm{G} \alpha_{\mathrm{s}}$ protein subtypes in adult and P0 mouse brain

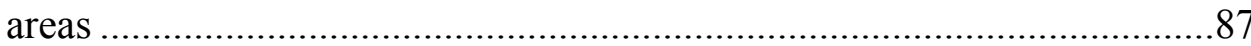

3.5 cAMP levels in mouse brainstem after activation with baclofen ..............91

3.6 Developmental changes of the GABAergig system ...............................92

3.6.1 A disruption in the balance between excitatory and inhibitory receptors: Neurodevelopmental disorder (MECP2).................................92

4.1 Developmental changes of the GABAergig system 94

4.1.1 Differential $\mathrm{GABA}_{\mathrm{B}}$-receptor-mediated modulation during brainstem

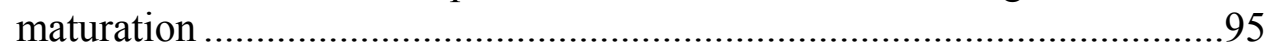

4.1.2 Diversity of $\mathrm{GABA}_{\mathrm{B}}$ receptor signaling through $\mathrm{G}$ protein variability .....96

4.2 Changes in the $\mathrm{GABA}_{\mathrm{A}}$ receptor signaling in the developing mouse brainstem in the model of Rett syndrome 


\section{List of abbreviation}

aa

ad

app.

ATP

bp

BSA

C

cAMP

cDNA

CNS

C-terminus

DEPC

DMSO

DNA

dNTP

E. coli

EDTA

EST

et al.

$\mathrm{EtBr}$

$\mathrm{EtOH}$

GDP

GTP

GABA

GIPs

GPCR

HEPES

HRP

HSP70

$\mathrm{IgG}$

IP

$\mathrm{kb}$ amino acid

"till end volume"

approximately

adenosine triphosphate

base pair(s)

bovine serum albumin

Celsius

cyclic adenosine monophosphate

complementary DNA

central nervous system

carboxy-terminus

diethylpyrocarbonate

dimethylsulphoxide

deoxyribonucleic acid

deoxynucleoside triphosphate

Escherichia coli

ethylenediaminetetraacetic acid

expressed sequence tag

and others

ethidiumbromide

ethanol

guanosine diphosphate

guanosine triphosphate

$\gamma$-amino butyric acid

GPCR interacting proteins

G protein coupled receptors

$N$-hydroxyethylpiperazine- $N^{\prime}$-2-ethanosulphonic acid horseradish peroxidase

heat shock protein 70

immunoglobulin $\mathrm{G}$

immunoprecipitation

kilo base 


$\begin{array}{ll}\text { kbp } & \text { kilo basepair } \\ \text { kDa } & \text { kilo dalton } \\ \mathrm{M} & \text { molar } \\ \mathrm{mA} & \text { milli ampere } \\ \text { MAPK } & \text { Mitogen-Activated Protein Kinase } \\ \text { MeCP2 } & \text { methyl-CpG-binding protein 2 } \\ \text { mM } & \text { milli molar } \\ \text { mRNA } & \text { messenger RNA } \\ \text { n } & \text { number in study or group } \\ \text { nM } & \text { nano molar } \\ \text { NMDA } & N \text {-methyl-d-aspartate } \\ \text { NP-40 } & \text { nonidet P-40 } \\ \text { OD } & \text { optical density } \\ \text { PAGE } & \text { polyacrylamide gel electrophoresis } \\ \text { PBS } & \text { phosphate buffered saline } \\ \text { PCR } & \text { polymerase chain reaction } \\ \text { PMSF } & \text { phenylmethylsulfonyfluoride } \\ \text { RNase } & \text { ribonuclease } \\ \text { rpm } & \text { rounds per minute } \\ \text { RT } & \text { room temperature } \\ \end{array}$

RT-PCR reverse transcript polymerase chain reaction

SDS-PAGE sodiumdodecylsulfate -polyacrylamide gel

sec second

TBE tris borate EDTA buffer

TBS tris-buffered saline

TEMED tetramethylendiamine

Tris tris-(hydroxymethyl)-aminomethan

Tween 20 polyoxyethylene sorbitane monolaurate

U Unit, enzyme activity

$\mathrm{v} / \mathrm{v} \quad$ volume per volume

Vol. volumes

$\mathrm{w} / \mathrm{v} \quad$ weight per weight

X-gal 5-bromo-4-chloro-3-indoyl-D-galactopyranoside 


\section{INTRODUCTION}

\subsection{G protein coupled receptors (GPCRs)}

The nervous system process a multitude of signals from the environment and within its cells. The ability of an organism to function normally depends on the capacity of nervous system cells to communicate effectively with each other and their environment. Specialized proteins called receptors, which are very specific to the signals they receive, regulate the signaling pathways. In terms of their structural and functional features, transmembrane receptors can be categorized as either ionotropic (transmitter-gated ion channels) or metabotropic receptors. To the metabotropic receptors belong the: G protein coupled receptors, Guanylyl cyclase receptors and Tyrosine Kinases receptors.

G protein coupled receptors (GPCRs) form one of the largest superfamilies of cellsurface receptors whose primary function is to transduce extracellular stimuli into intracellular signals. The chemical diversity of the GPCRs ligants is exceptional and includes endogenous ligants such as hormones and neurotransmitters and neuromodulators such as biogenic amines, amino acids, peptides, glycoproteins, prostanoids, phospholipids, nucleosides and nucleotides, ions (Gether 2000; Howard, McAllister et al. 2001; Lee, George et al. 2001) and exogenious ligants, such as odors, pheromones, light, or tastes (Firestein 2000). Despite the remarkable structural diversity of their activating ligands, all GPCRs are predicted to share a common molecular architecture consisting of a single protein chain (300-1000 amino acids) that crosses the membrane seven times (seven-transmembrane $\mathrm{G}$ protein Coupled Receptors, 7-TM GPCRs) (Ulloa-Aguirre, Stanislaus et al. 1999). The seven transmembrane $\alpha$-helical segments (TM I-VII), usually consisting of 20 to 27 amino acids each, are connected by three intracellular (i1, i2 and i3) and three extracellular (e1, e2 and e3) loops (Baldwin 1993), with the amino terminus located on the extracellular side and the carboxy terminus on the intracellular side (Wess 1997). The $\mathrm{N}$-terminal segment is the site of glycosylation and ligand binding, the C-terminal segment allows palmitoylation and phosphorylation as prerequisites for 
desensitization and internalization (Liebmann and Bohmer 2000). The intracellular loops transmit the signal from the receptor to $G$ protein.

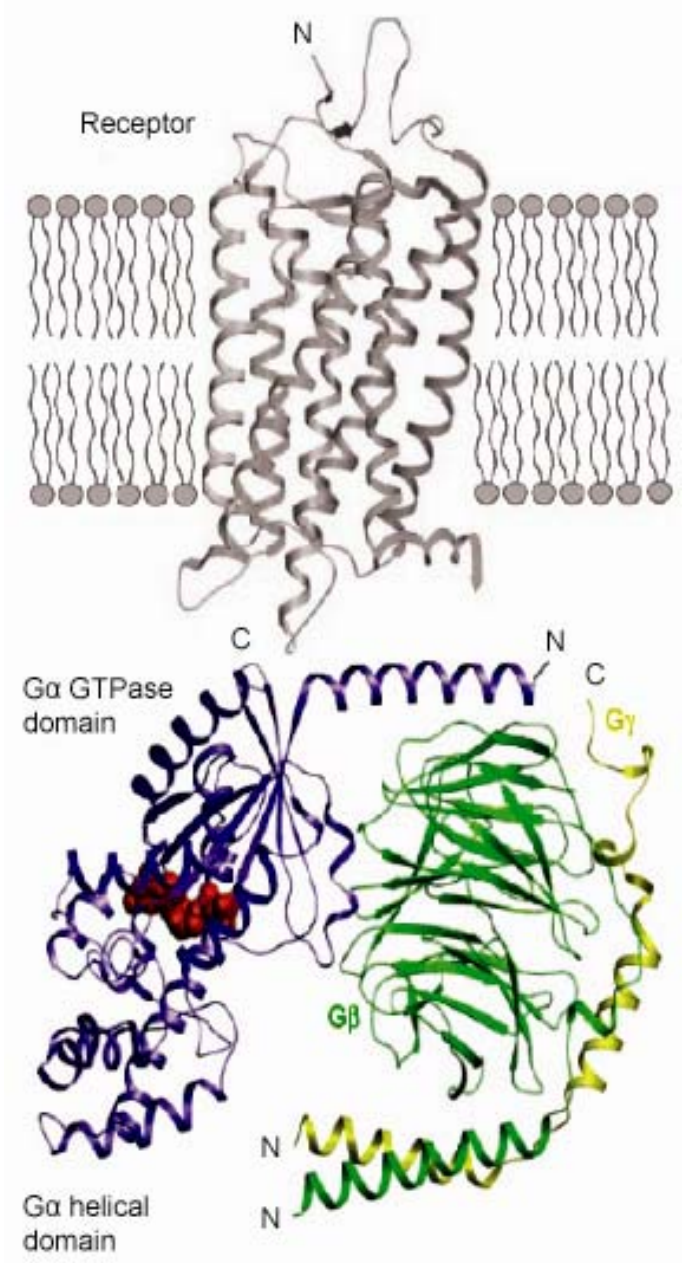

Figure 1.1. GPCR and $G$ protein complex. Ribbon model of bovine rhodopsin, showing the seven transmembrane spanning $\alpha$-helices (gray), which has been cross linked to several sites on the $G$ protein. The N-terminal and the C-terminal ends of the $\mathrm{G} \alpha$ (blau), G $\beta$ (green) and $\mathrm{G} \gamma$ (yellow) subunits are marked with the letters $\mathrm{N}$ and $\mathrm{C}$ respectively. The GDP molecule is buried between the GTPase and helical domain of Ga. Adapted and modified from (Lambright, Sondek et al. 1996).

The structure of the GPCRs has been confirmed by analysis of the crystal structure of Rhodopsin (Baldwin 1993; Palczewski, Kumasaka et al. 2000) that has been extensively used as template for homology-based modelling of GPCRs (see Figure 1.1) (Orry and Wallace 2000).

\subsubsection{Evolution \& Structural Classification of GPCRs}

GPCRs are the oldest known signal transducers present in the genome of plants (Plakidou-Dymock, Dymock et al. 1998), yeast (Dohlman, Thorner et al. 1991) and slime mold (Dictyostelium discoideum) (Devreotes 1994), as well as in protozoa and the earliest diploblastic metazoan (Vernier, Cardinaud et al. 1995; New and Wong 
1998). In vertebrates, the GPCR family contains $1000-2000$ members ( $>1 \%$ of the genome) including $>1000$ coding for odorant and pheromone receptors (Bockaert and Pin 1999). In a recent analysis of the GPCRs in the human genome, more than 800 GPCRs were listed (Fredriksson, Hoglund et al. 2003). Of this total, 701 were in the rhodopsin family (type A) (Fredriksson, Lagerstrom et al. 2003).

A study similar to that of Fredriksson et al. (Fredriksson, Hoglund et al. 2003), showed that the repertoire of GPCRs for endogenous ligands consist of 367 receptors in human and 392 in mice [endoGPCR refers to GPCRs for endogenous (nonolfactory) ligands]. In view of the known existence of alternatively spliced variants and editing isoforms of GPCRs, it is likely that the true number of GPCRs will never be known and is much higher than estimated. (Kroeze, Sheffler et al. 2003).

All GPCR members have seven transmembrane domains but, on the base of shared sequence motifs, they are grouped into six classes: A, B, C, D, E and the frizzled/smoothened family (Horn, Weare et al. 1998).

Family A is by far the largest and the most studied. It includes biogenic amine receptors (adrenergic, serotonin, dopamine, muscarinic, histamine), adenosine, cannabionoid, melanocortin, olfactory receptors, melatonin receptors plus others.

Family B receptors include approximately 20 different receptors for a variety of peptide hormones and neuropeptides, such as calcitonin and glucagon.

Family $\mathrm{C}$ receptors are characterized by an exceptionally long amino terminus (500600 amino acids). The receptors include the Metabotropic glutamate and $\gamma$ aminobutyric acid (GABA) receptors, the calcium receptors, the vomeronasal, mammalian pheromone receptors, and the recently identified putative taste receptors (Gether 2000; Sadee, Hoeg et al. 2001).

Yeast pheromone receptors make up two minor unrelated subfamilies, family D and family E. In Dictyostlium Discoideum four different cAMP receptors constitute yet another minor, but unique, subfamily of GPCRs (Family F).

\subsection{GPCR signaling}

GPCRs have been named based on their ability to recruit and regulate the activity of intracellular Heterotrimeric G proteins (Gether 2000). When a ligand such as a 
hormone, neurotransmitter, or glycoprotein interacts with a heptahelical receptor on the surface of the cell, the ligand either stabilizes or induces a conformation in the receptor that activates a heterotrimeric $\mathrm{G}$ protein (composed of $\alpha, \beta$, and $\gamma$-subunits) on the inner membrane surface of the cell. In the inactive heterotrimeric state, GDP is

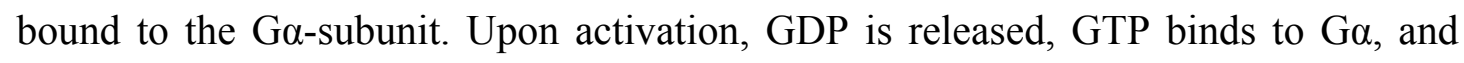
subsequently G $\alpha$-GTP dissociates from G $\beta \gamma$ and from the receptor (see Figure 1.1) Both the G $\alpha-G T P$ and the G $\beta \gamma$ dimer activate a number of enzyme activities (effectors) or ionic channels which regulate the intracellular concentrations of secondary messengers such as cAMP, cGMP, diacylglycerol (DAG), IP3, arachidonic acid, sodium, potassium or calcium cations (Gilman 1987; Sprang 1997). Different GPCR subtypes couple to different $\mathrm{G} \alpha$ subfamilies $\left(\mathrm{G} \alpha_{\mathrm{s}}, \mathrm{G} \alpha_{\mathrm{i} / \mathrm{o}}, \mathrm{G} \alpha_{\mathrm{q}}\right.$, and $\left.\mathrm{G} \alpha_{12 / 13}\right)$, thus exerting different downstream effects on a cell (Hamm 1998; Cabrera-Vera, Vanhauwe et al. 2003; Kurose 2003).

The mechanism by which GPCRs transduce extracellular messages into intracellular cellular responses was initially envisioned as a simple model. Recently, this view has been extended in order to explain the complexity of the GPCR signaling. Thus, it has become more important to investigate further the role of the $G$ protein variability, the GPCRs diversity, and the ligants heterogeneity, for the receptor modulation. Furthermore, GPCRs interact not only with G proteins but also with a variety of other proteins. The later interaction influences the signal variability too.

\subsubsection{GPCR signaling specificity through $G$ protein variability}

There are at least 21 different $\alpha, 5$ different $\beta$, and 13 different $\gamma$ subunits in human (Downes and Gautam 1999; Venter, Adams et al. 2001) to which GPCRs can be coupled (Hermans 2003; Wong 2003). The influence of the different G protein subtypes in the mechanisms of signaling has been demonstrated, based on the $\beta 2$ adrenoceptor receptors. Seifert et al. (Seifert, Wenzel-Seifert et al. 1998) proposed that the structural differences between two different splice variants of $G \alpha_{s}$-protein might influence the binding of $\beta 2$-adrenoceptor to $\mathrm{G} \alpha_{\mathrm{s}}$-protein.

Another layer of complexity arises from the ability of each $G$ protein to activate multiple downstream effectors. Both $G \alpha$ and $G \beta \gamma$ subunits contribute to the modulation, in a synergistic or antagonistic fashion, of either the same or unrelated 
effectors, resulting in dual intracellular signaling. An example is the simultaneous $\mathrm{G \alpha}_{\mathrm{i} / \mathrm{o}}$-mediated inhibition of adenylate cyclase via the $\mathrm{G} \alpha$ subunit and stimulation of phospholipase $C \beta$ via the G $\beta \gamma$ subunit (Exton 1996). In Addition, single GPCRs are able to activate simultaneous multiple $G$ protein pools. Dual coupling to $G \alpha_{\mathrm{s}}$ and $\mathrm{G} \alpha_{\mathrm{q} / 11}$ (Jin, Wang et al. 2001) or to $\mathrm{G} \alpha_{\mathrm{i} / \mathrm{o}}$ and $\mathrm{G} \alpha_{\mathrm{q} / 11}$ (Offermanns, Heiler et al. 1994) has now been reported for many GPCRs. In some cases, a single receptor has been found to simultaneously activate members of three or even four unrelated classes of $\mathrm{G}$ protein $\left(\mathrm{G} \alpha_{\mathrm{s}}, \mathrm{G} \alpha_{\mathrm{i} / \mathrm{o}}, \mathrm{G} \alpha_{\mathrm{q} / 11}\right.$, and $\left.\mathrm{G} \alpha_{12}\right)$ (Laugwitz, Allgeier et al. 1996).

\subsubsection{GPCR signaling specificity through the complexity of the GPCRs.}

The existence of receptor subtypes represents the second level of specificity in GPCR signal transduction. Through a variety of mechanisms, genes encoding GPCRs have duplicated and spread throughout eukaryotic genomes. Thus, at least 5 closely related human genes encode muscarinic cholinergic receptors, 5 encode dopamine receptors, and at least 15 encode serotonin receptors (Felder, Graul et al. 1999). A number of GPCR genes exist as a single exon but many GPCR genes are multiexonic. This indicates the existence of splice variants with distinct functions, as has been demonstrated for the prostaglandin EP3 receptor subtype. Alternative splicing of EP3 yields at least 4 isoforms that differ in their $\mathrm{C}$-terminus and couple to different $\mathrm{G}$ proteins and second messengers (Namba, Sugimoto et al. 1993). In addition Pindon et al. (Pindon, van Hecke et al. 2002) demonstrated that the human 5-HT4a receptor binds to $\mathrm{G} \alpha_{\mathrm{s}}$-protein, whereas it's C-terminal splice variant 5-HT4b receptor binds to both $G \alpha_{\mathrm{i}^{-}}$and $\mathrm{G} \alpha_{\mathrm{s}}$-proteins, when expressed in HEK293 cells. Many more splice variants can be expected that have yet to be studied; for a review, see (Gudermann, Kalkbrenner et al. 1996; Sadee, Hoeg et al. 2001).

\subsubsection{GPCR signaling specificity through ligands heterogeneity}

Ligants interact with different extracellular and/or transmembrane domains of GPCRs, in order to convey their messages to the interior of the cell. For each of the ligands, exist distinct binding sites in the GPCRs, either embedded within the pocket formed by the 7-TM bundle within the membrane (biogenic amines), or at pockets 
formed by the extracellular loops (peptides). For the metabotropic glutamate and GABA receptors, the ligand-binding sites are contained within the large extracellular domain characterizing family C receptors (Coughlin 1994).

The binding modes for agonists acting at GPCRs are almost as diverse as the nature of their ligands. Even various agonists acting at the same receptor may not necessarily share an overlapping binding site (Schwartz and Rosenkilde 1996). Thus, liganddependant stimulation can activate coupling to different $\mathrm{G}$ protein subtypes. In case of $\beta 2$-adrenergic receptor, the antagonist ICI-118-551, which behaves as an inverse agonist for coupling to $\mathrm{G} \alpha_{\mathrm{s}}$, act as an agonist for $\beta 2$-adrenergic receptor coupling to $\mathrm{G} \alpha_{\mathrm{i}}$ (Gong, Sun et al. 2002). An example for ligand-dependant stimulation has been showed from Heubach et al. (Heubach, Ravens et al. 2004), where binding of $\beta 2$ adrenoceptor to either $\mathrm{G} \alpha_{\mathrm{i}}$ or $\mathrm{G} \alpha_{\mathrm{s}}$ depends on whether the receptor has been activated by epinephrine or norepinephrine; or in the example of Houston et al. where structurally distinct ligands modulate differently $\left(\mathrm{G} \alpha_{i}\right.$ or $\mathrm{G} \alpha_{0}$ coupling) the cannabimimeric $\mathrm{CB}_{1}$ receptor (Houston and Howlett 1998). Lastly, the idea that a given receptor can be coupled to two different pathways depending on the duration of activation (and therefore potential desensitization) has also been reported in the case of mGluRs (Pin 1998).

Despite all this ligand-binding dependant GPCR signaling experiments, they appear cases of spontaneous basal signaling activity in the absence of agonists (also referred to as constitutive activity) (Lefkowitz, Cotecchia et al. 1993). Constitutive activity of wild-type $\beta 2$ adrenergic (Chidiac, Hebert et al. 1994), serotonin (Barker, Westphal et al. 1994), bradykinin (Leeb-Lundberg, Mathis et al. 1994), d-opioid (Costa and Herz 1989), and muscarinic (Jakubik, Bacakova et al. 1995) receptors has been reported. It has also been observed that discrete mutations are able to dramatically increase this constitutive agonist-independent receptor activity (Kjelsberg, Cotecchia et al. 1992; Samama, Cotecchia et al. 1993). The majority of the constitutively activating mutations were initially identified after mutational substitutions in the C-Terminal part of the third intracellular loop of the adrenergic receptors (Kjelsberg, Cotecchia et al. 1992; Samama, Cotecchia et al. 1993), but currently activating mutations have been identified in almost any receptor domain in an increasing number of receptors [representative examples in (Porter, Hwa et al. 1996; Burstein, Spalding et al. 1998; Hjorth, Orskov et al. 1998)]. 


\subsubsection{GPCR signaling specificity in a cell- or tissue-dependent manner}

The signal transduction also depends on the cell or tissue. Studies on the pleiotropic hormone bradykinin have shown that it is capable of activating different $G$ proteins and multiple signaling pathways (Table 1) according to the cell or tissue that they are expressed.

Table 1.1. Typical bradykinin signaling pathways: multiple coupling and cell specificity

\begin{tabular}{|c|c|c|c|}
\hline Cell/Tissue & Effector & Mechanism & Ref. \\
\hline $\begin{array}{l}\text { A431 cells, guinea } \\
\text { pig ileum, others }\end{array}$ & PLCb (stimulation) & via $G \alpha_{\mathrm{q} / 11}$ & (Tilly, van Paridon et al. 1987) \\
\hline $\begin{array}{l}\text { fibroblasts, rat } \\
\text { myometrial cells }\end{array}$ & PLA2 (stimulation) & $\begin{array}{l}\text { partially via } \\
G \alpha_{i}\end{array}$ & (Tropea, Munoz et al. 1992) \\
\hline A431 cells & $\mathrm{AC}$ (stimulation) & via $G \alpha_{s}$ & (Liebmann, Graness et al. 1996) \\
\hline $\begin{array}{l}\text { airway smooth } \\
\text { muscle cells }\end{array}$ & $\mathrm{AC}$ (stimulation) & $\begin{array}{l}\text { via } \mathrm{G} \alpha_{\mathrm{q} / 11}, \\
\text { PKC, MAPK, } \\
\text { PLA2, PGE2 }\end{array}$ & (Pyne, Tolan et al. 1997) \\
\hline Rat uterus, GPI & AC (inhibiton) & via $G \alpha_{i}$ & (Liebmann, Graness et al. 1995) \\
\hline
\end{tabular}

\subsubsection{GPCR signaling specificity through GIPs}

Recent studies have shown that GPCR signaling exhibits greater diversity than previously appreciated. It is now evident that signaling specificity of a GPCR is not only dependent of the nature of the heterotrimeric G proteins, ligands, and GPCR subtypes, but also on the nature of the GPCR interacting proteins (GIP) (Hall and Lefkowitz 2002; Bockaert, Marin et al. 2003; Kroeze, Sheffler et al. 2003). The nature of these GIPs is different, depending on the cell in which the receptor is expressed (Bockaert, Fagni et al. 2004). There are several types of GIPs. Some are transmembrane proteins such as another GPCR (homodimerization and heterodimerization), ionic channels, ionotropic receptors, single transmembrane proteins and soluble proteins. GIPs are implicated in (a) targeting of GPCRs to specific cellular compartment, (b) association with other signaling or structural 
proteins, and (c) the fine-tuning of their signal transduction, including desensitization and resensitization.

\subsubsection{Specificity arising within membrane microdomains}

Experimental evidence indicates that GPCRs, G proteins, and effectors are not randomly distributed in the plasma membrane. Indeed, it has been suggested that GPCR signaling mainly occurs within specialized microdomains, implying that the efficiency and specificity of signal transduction are dictated by the stoichiometry of transducer elements within spatially discrete membrane regions (Neubig 1994; Ostrom, Post et al. 2000; Ostrom 2002). Thus the same receptor may regulate a $\mathrm{Ca}^{2+}$ channel through one $\mathrm{G}$ protein at a nerve terminal and regulate PLC $\beta$ at a distal dendrite through another $G$ protein. One of the most studied forms of membrane microdomain are regions of high-density cholesterol, gangliosides, and sphingolipids, referred to as caveolae or lipid rafts (Galbiati, Razani et al. 2001).

\subsubsection{Association with other signaling or structural proteins}

In addition to G proteins, GPCRs are known to interact with many other proteins, some of which may also have signaling functions (Heuss and Gerber 2000). Receptor associated proteins include arrestins, protein kinases and phosphatases, PDZ-domain binding proteins (Bockaert and Pin 1999) and various modifying enzymes, for example those introducing palmitoyl residues into the C-terminus.

\section{a. Interaction with other GPCR (homodimerization and heterodimerization of GPCR)}

Most GPCRs are predicted to form homodimers or heterodimers (Chabre et al. 2003; Liang et al. 2003), an idea first proposed by Rodbell (1992). The molecular mechanisms of dimer formation seem to differ considerably among the receptors.

The importance of the heterodimerization has been demonstrated (Kaupmann, Malitschek et al. 1998; White, Wise et al. 1998; Jones, Borowsky et al. 1998; Kuner, Kohr et al. 1999), based on the $\mathrm{GABA}_{\mathrm{B}}$ receptors. The functional $\mathrm{GABA}_{\mathrm{B}}$ receptor is a heterodimers, composed of the $\mathrm{GABA}_{\mathrm{B}} \mathrm{R} 1$ (GB1) and $\mathrm{GABA}_{\mathrm{B}} \mathrm{R} 2$ (GB2) subunits (Jones, Borowsky et al. 1998; Kuner, Kohr et al. 1999). Formation of the GB1-GB2 
dimer within the endoplasmatic reticulum (ER) is needed for the trafficking to the membrane (GB1 is retained within the ER via a RXR (R) motif within its Cterminus).

Another example which shows the importance of the GPCR dimerization has been also demonstrated based on the $\beta 2$-adrenergic receptor; a peptide corresponding to the sixth TM of the $\beta 2$-adrenergic receptor inhibits both receptor dimerization and activation (Hebert, Moffett et al. 1996), suggesting that GPCR dimerization may be important for $\mathrm{G}$ protein activation.

\section{b. Interaction with ionic channels and ionotropic receptors}

An example which shows the fine-tuning of GPCRs through their interaction with ionotropic receptors is the interaction between the dopamine D5 receptor and the ionotropic $\mathrm{GABA}_{\mathrm{A}}$ receptors. Both receptors are localized in dentritic shafts and the cell soma/axon hillock area. The C-terminus of D5 (but not D1) receptors interacts with the second intracellular (i2) loop of $\mathrm{GABA}_{\mathrm{A}}$ receptor $\gamma 2$ subunit. This leads to a mutually inhibitory interaction between $\mathrm{D} 5$ and $\mathrm{GABA}_{\mathrm{A}}$ receptors (Liu, Wan et al. 2000).

\section{c. Interaction with single transmembrane proteins and soluble proteins}

A final source of GPCR signaling diversity arises from data suggesting that GPCRs transmit "G protein-independent" signals and that coupling to certain non-G protein effectors exhibits features consistent with agonist-specific trafficking.

The intracellular domains of several GPCRs have been shown to bind to proteins that might function as alternative GPCR signal transducers, among which include GEFs for small G proteins, nonreceptor tyrosine kinases, and several proteins that function as adaptors or scaffolds (Miller and Lefkowitz 2001; Maudsley, Martin et al. 2005). For example the $\mathrm{C}$-termini of $\mathrm{GABA}_{\mathrm{B}} \mathrm{R} 1$ and $\mathrm{GABA}_{\mathrm{B}} \mathrm{R} 2$ receptors, which contribute to their heterodimerization, are engaged in an interaction with the leucine zipper domain of cAMP-responsive element binding protein 2 (CREB2, also called $\mathrm{ATF}_{4}$ ) and $\mathrm{ATF}_{\mathrm{x}}$ (Nehring, Horikawa et al. 2000; White, McIllhinney et al. 2000; Vernon, Meyer et al. 2001). CREB2 and $\mathrm{GABA}_{\mathrm{B}}$ receptors are colocalized in soma and dendrites of cultured hippocampal neurons. $\mathrm{GABA}_{\mathrm{B}}$ receptors activate CREB2 translocation to the nucleus and gene transcription in heterologous systems (White, McIllhinney et al. 2000). 


\section{d. Desensitization and internalization as a modifier of signal quality}

Desensitization has been show to play a role not only in limiting signal duration and intensity, but also in the determination of signal quality. Desensitization is initiated by receptor phosphorylation. Daaka et al. (Daaka, Luttrell et al. 1997) showed that this receptor phosphorylation modifies the coupling specificity of the $\beta 2$-adrenergic receptor. Activation of $\beta 2$-adrenoceptor causes primarily an increase of the level of PKA by Gs-mediated signaling pathway. The elevation of PKA phosphorylates the

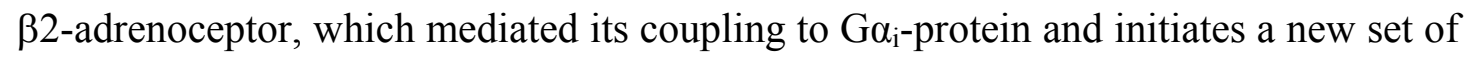
signaling events.

\subsection{The heterotrimeric $G$ proteins}

Heterotrimeric G proteins are part of the GTPase superfamily that also includes small GTP-binding proteins and many factors involved in protein synthesis (s. chapter 1.4). "G protein" usually refers to the membrane-associated heterotrimeric G proteins, sometimes referred to as the "large" G proteins. These proteins are activated by $\mathrm{G}$ protein coupled receptors and are composed of three subunits: alpha $(\alpha)$, beta $(\beta)$ and $\operatorname{gamma}(\gamma)$.

When a ligand binds to a $\mathrm{G}$ protein coupled receptor (GPCR) on the exterior surface of a cell, it induces a conformational change in the GPCR and that activates the bound heterotrimeric G protein. The G protein then releases the GDP from the Ga subunit, and binds a GTP. This exchange triggers the dissociation of the $\mathrm{G} \alpha$ subunit, the $\mathrm{G} \beta \gamma$

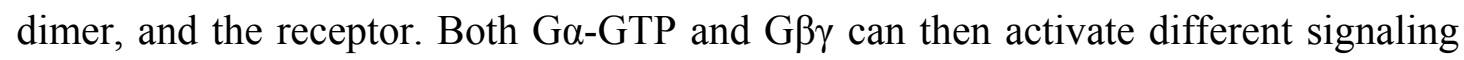
cascades and effector proteins, while the receptor is able to activate the next G protein (s. chapter 1.4). The G $\alpha$ subunit will eventually hydrolyze the attached GTP to GDP, allowing it to reassociate with G $\beta \gamma$ and starting a new cycle.

\subsubsection{Structure and diversity of $G$ proteins}

Heterotrimeric $\mathrm{G}$ proteins consist of $\alpha, \beta$ and $\gamma$ subunits (encoded by distinct genes) each of which has multiple isoforms. In addition, there are many splice variants for some of these isoforms, which together can make up hundreds of combinations of $G$ 
proteins. The specific combination of $\alpha, \beta$ and $\gamma$ subunits affects not only which receptor it can bind to, but also which downstream target is affected, providing the means to target specific physiological processes in response to specific external stimuli (Yan, Kalyanaraman et al. 1996; Scott, Huang et al. 2001).

Table 1.2. Classification of $\mathbf{G} \alpha$-subtypes and their effectors (Burstein, Spalding et al. 1998)

\begin{tabular}{|c|c|c|}
\hline Family & Subtyp & Effector \\
\hline $\mathrm{G} \alpha_{\mathrm{s}}$ & $\begin{array}{l}\mathrm{G} \alpha_{\mathrm{s}(\mathrm{S})} \\
\mathrm{G} \alpha_{\mathrm{s}(\mathrm{L})} \\
\mathrm{G} \alpha_{\text {olf }}\end{array}$ & $\begin{array}{l}\uparrow \mathrm{AC} \\
\uparrow \mathrm{GTPase} \text { of tubulin } \\
\uparrow \mathrm{src} \\
\uparrow \mathrm{AC}\end{array}$ \\
\hline $\mathrm{G} \alpha_{\mathrm{i}}$ & $\begin{array}{l}\mathrm{G} \alpha_{\mathrm{i} 1} \\
\mathrm{G} \alpha_{\mathrm{i} 2} \\
\mathrm{G} \alpha_{\mathrm{i} 3} \\
\mathrm{G} \alpha_{\mathrm{oA}} \\
\mathrm{G} \alpha_{\mathrm{oB}} \\
\mathrm{G} \alpha_{\mathrm{z}} \\
\mathrm{G} \alpha_{\mathrm{t} 1} \\
\mathrm{G} \alpha_{\mathrm{t} 2} \\
\mathrm{G} \alpha_{\mathrm{g}}\end{array}$ & $\begin{array}{l}\downarrow \text { AC } \\
\text { Rap 1GAP } \\
\text { GRIN } 1 \text { and } 2 \\
\uparrow \text { GTPase of tubulin } \\
\uparrow \text { src } \\
\mathrm{Ca}^{2+} \text { and } \mathrm{K}^{+} \text {channels } \\
\uparrow \text { cGMP-PDE } \\
\text { Unknown }\end{array}$ \\
\hline $\mathrm{G} \alpha_{\mathrm{q}}$ & $\begin{array}{l}\mathrm{G} \alpha_{\mathrm{q}} \\
\mathrm{G} \alpha_{11} \\
\mathrm{G} \alpha_{14} \\
\mathrm{G} \alpha_{15} \text { or }{ }_{16}\end{array}$ & $\begin{array}{l}\uparrow \mathrm{PLC} \beta s \\
\uparrow \text { Bruton's tyrosine kinase }\left(\mathrm{G} \alpha_{\mathrm{q}}\right)\end{array}$ \\
\hline $\mathrm{G} \alpha_{12}$ & $\begin{array}{l}\mathrm{G} \alpha_{12} \\
\mathrm{G} \alpha_{13}\end{array}$ & $\begin{array}{l}\uparrow \text { NHE-1 } \\
\uparrow \mathrm{PLD} \\
\uparrow \mathrm{p} 115 \mathrm{RhoGEF} \\
\uparrow \mathrm{iNOS}\end{array}$ \\
\hline
\end{tabular}

PDE, Phosphodiesterase E; iNOS, inducible nitric oxide synthetase; NHE, $\mathrm{Na}^{+} / \mathrm{H}^{+}$exchanger; PLD, phospholipase D; GEF, guanine nucleotide exchange factor; $\mathrm{G} \alpha_{\mathrm{s}(\mathrm{s})}, \mathrm{G} \alpha_{\mathrm{s}}$ short ; $\mathrm{G} \alpha_{\mathrm{s}(\mathrm{L})}$, $\mathrm{G} \alpha_{\mathrm{s}}$ long.

Crystallographic studies of $G$ proteins have shown that the alpha subunit of heterotrimeric $\mathrm{G}$ proteins consists of two domains; a GTPase domain and an alphahelical domain (see Figure 1.1). The GTPase domain consists of five helices surrounding a six-stranded beta sheet with five strands running parallel and one strand antiparallel to the others. The GTPase domain hydrolyzes GTP and contains site for binding to the G $\beta \gamma$ dimmer, heptahelical receptors and downstream effector proteins (Clapham and Neer 1997). The helical domain is composed of six $\alpha$-helices. This 
domain is responsible for increasing the affinity of $\mathrm{G} \alpha$ for guanine nucleotides (Remmers, Engel et al. 1999), for increasing the GTP hydrolysis activity of the protein (Markby, Onrust et al. 1993) and it may also play a significant role in coupling specific $\mathrm{G}$ proteins to specific effectors.

The structure of the beta subunit is a "beta propeller" protein, with seven distinct beta sheet domains arranged like blades on a propeller and an $\alpha$-helical conformation at the $\mathrm{N}$-terminus which forms a coiled coil that is essential for the interaction with the $\gamma$ subunit (Fong, Amatruda et al. 1987). The gamma subunit is composed of two $\alpha$ helices connected by a loop, where the $\mathrm{N}$-terminal helix interacts with the $\mathrm{N}$-terminus of the beta subunit and the C-terminal helix (Sondek, Bohm et al. 1996).

$\mathrm{G}$ proteins are named after their $\alpha$ subunits. On a basis of sequence identity, at least $21 \alpha$ subunits encoded by 16 genes, with several alternatively spliced isoforms, have been identified and classified into four subfamilies: (i) $\mathrm{G} \alpha_{\mathrm{s}}$ and (ii) $\mathrm{G} \alpha_{\mathrm{i} / \mathrm{o}}$, which stimulate and inhibit respectively adenylate cyclase, (iii) $\mathrm{G} \alpha_{\mathrm{q} / 11}$ which stimulate phospholipase $\mathrm{C}$, and (iv) the less characterized $\mathrm{G} \alpha_{12 / 13}$ subfamily that activates the $\mathrm{Na}^{+} / \mathrm{H}^{+}$exchanger pathway (Hamm 1998). Members of this family range in size from 39-52 $\mathrm{kDa}$ and share between $35 \%$ and $95 \%$ sequence identity (Downes and Gautam 1999). The $G \alpha_{i}$ class was named for the ability of some of its members to inhibit adenylyl cyclase and includes $\alpha_{\mathrm{i}-1}, \alpha_{\mathrm{i}-2}, \alpha_{\mathrm{i}-3}$, which are products of different genes. There is no evidence for alternatively spliced products being encoded by these genes; $\mathrm{G} \alpha_{0}$ (for o "other" because its function was unclear) is a predominantly neural $\alpha$ subunit, which is also a product of a separate gene that can be spliced to generate at least two polypeptides, $\alpha_{\mathrm{o} 1}, \alpha_{\mathrm{o} 2}$; the rod transducin $\alpha$ subunits $\alpha_{\mathrm{t} 1}$ and $\alpha_{\mathrm{t} 2}$, which transduce visual signals in conjunction with rhodopsin in the retina. $\mathrm{G} \alpha_{\mathrm{t}}$ triggers the breakdown of cyclic GMP; $\mathrm{G} \alpha_{z}$ and $\mathrm{G} \alpha_{\text {gust }}$ (gustducin). All the members of this class, except $\alpha_{z}$, can be modified by pertussis toxin.

The $\mathrm{G} \alpha_{\mathrm{s}}$ class was first recognized by its ability to activate adenylyl cyclase and includes the $\mathrm{G} \alpha_{\mathrm{s}}$ and $\mathrm{G} \alpha_{\mathrm{olf}}$ (an $\alpha$ subunit from olfactory neuroepithelium which couples to olfactory receptors).

The $\mathrm{G} \alpha_{\mathrm{q}}$ class includes $\mathrm{G} \alpha_{\mathrm{q}}, \mathrm{G} \alpha_{11}, \mathrm{G} \alpha_{14}, \mathrm{G} \alpha_{15}$ and $\mathrm{G} \alpha_{16}$. Members of this class activate phospholipase C (see chapter 1.4.1.1) (Strathmann and Simon 1990).

The fourth class includes $\alpha_{12}$ and $\alpha_{13}$, important for regulating the cytoskeleton, cell junctions, and other processes related to movements 
G $\beta \gamma$ is a tightly complexed dimer that dissociates only under denaturing conditions. It can act as a signaling molecule itself, by activating other second messengers or by gating ion channels directly (Ikeda and Dunlap 1999). Both G $\beta$ and $G \gamma$ subunits also consist of multiple proteins. There are currently five $\mathrm{G} \beta$ and $12 \mathrm{G} \gamma$ subunits (Clapham and Neer 1997). The five $\beta$ subtypes identified so far in mammals have a molecular mass close to $35-36 \mathrm{kDa}$, and are encoded by 5 genes having a 50-83\% identity between them. The two G $\beta$ subclasses based on amino acid homology are the $\beta 1-\beta 4$ and $\beta 5$. The $\gamma$ subunit is a relatively diverse group of much smaller proteins of 8-10 $\mathrm{kDa}$ each. These proteins all undergo posttranslational modifications, leading to further diversity within this subunit family. The 12 mammalian $\gamma$ subunit types are encoded by 12 genes: $\gamma 1$ to 12 (Gautam, Downes et al. 1998). The existence of 12 different $\gamma$ subunits, five different $\beta$ and at least $20 \alpha$ subunits and many splice variants indicates that there are many possibilities for different combinations. But, in fact, not all the possible pairs can be formed. For example by transient expression in COS cells, $\beta 1$ is able to interact with $\gamma 1$ and $\gamma 2$, but the very similar $\beta 2$ molecule is able to form a dimer only with $\gamma 2$ (Pronin and Gautam 1992). In addition, some subunits are very cell-specific, for example, the $\alpha$ subunits on specialized sensory systems, including olfactory, visual and lingual tissues $\left(\mathrm{G} \alpha_{\text {olf }} /\right.$ Olfactory neuroepithelium, $\mathrm{G} \alpha_{\mathrm{t} 1} /$ rod photoreceptors; $\mathrm{G} \alpha_{\mathrm{t} 2} /$ cone photoreceptors and $\mathrm{G} \alpha_{\text {gust }} /$ taste buds) with highly restricted distribution patterns, or the $\mathrm{G} \alpha_{0}$ predominantly expressed in brain and the $\mathrm{G} \alpha_{15}$ in hematopoietic cells. The $\beta 5, \gamma 3$ and $\beta 4$, are mainly expressed in the nervous system.

\subsubsection{The complexity of the stimulatory $G\left(G \alpha_{s}\right)$ protein}

In contrast to the members of the $\mathrm{G} \alpha_{\mathrm{i}}, \mathrm{G} \alpha_{\mathrm{q}}$ and $\mathrm{G} \alpha_{12}$ subfamilies, the $\mathrm{G} \alpha_{\mathrm{s}}$ gene is located in a rather complex genomic locus (GNAS). Gnas is a complex imprinted gene (genes whose expression is determined by the parent that contributed them) whose major gene products are generated by at least four alternative promoters and first exons that splice onto a common exon (exon 2) (Weinstein, Yu et al. 2001).

There has been a continuous stream of new data, as well as some conflicting reports based on the localisation, function and the number of the alternative splice variants of the Gnas gene products. The human $G \alpha_{\mathrm{s}}$ gene (GNAS1), is located on human 
chromosome 20q13.2 while its mouse ortholog (Gnas) is located in a distal portion of chromosome 2 (Blatt, Eversole-Cire et al. 1988; Holmes, Williamson et al. 2003).

A

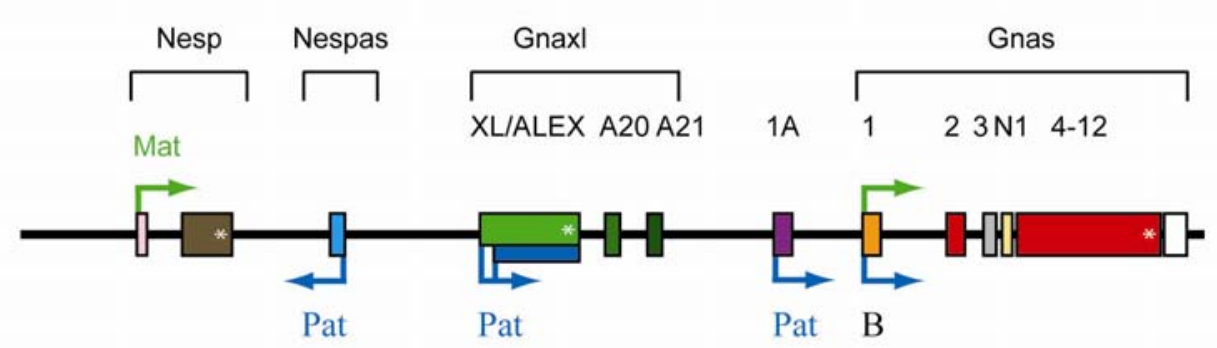

B
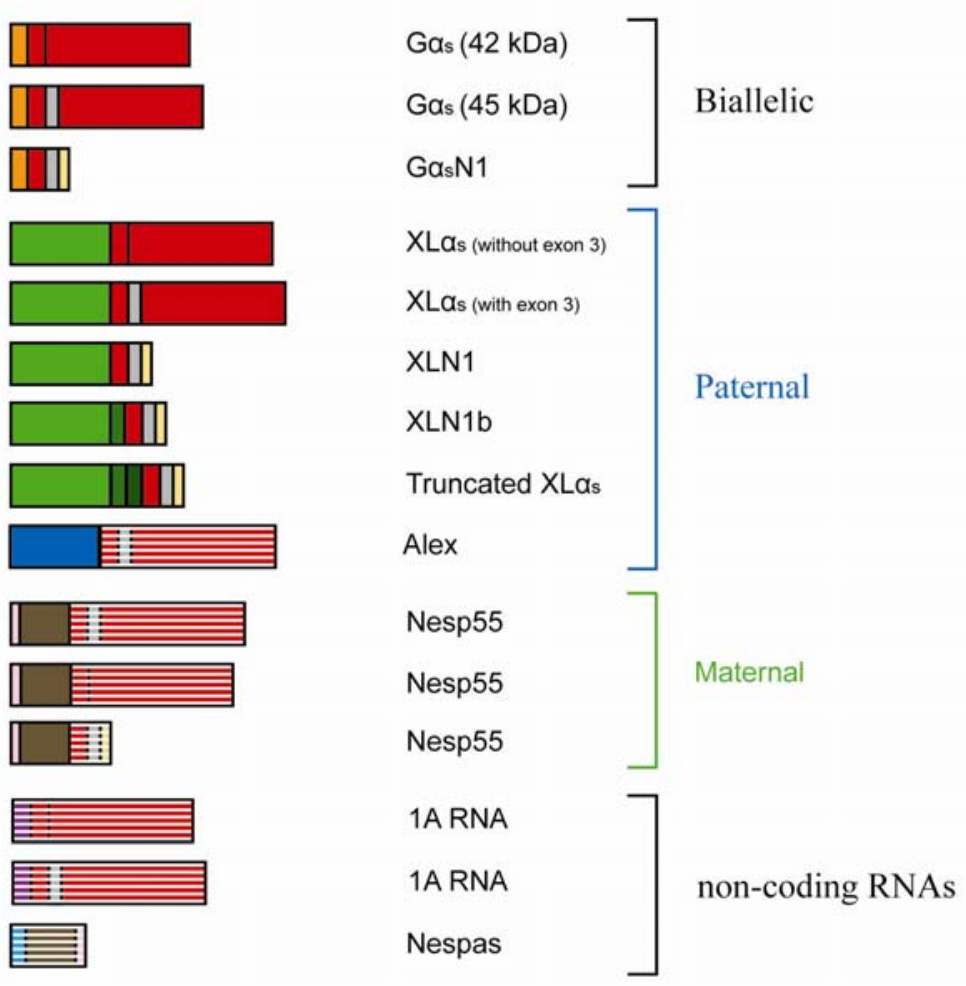

Figure 1.2. Scheme of the imprinted Gnas locus of the mouse. Promoters and the direction of transcription are shown by the arrows; Mat (maternal), Pat (paternal) and $\mathrm{B}$ (biallelic). The Gnas promoter (encoding $\mathrm{G} \alpha_{\mathrm{s}}$ ) is biallelically expressed. The neural-specific form is marked as GasN1. Gnasxl encodes an N-terminal variant of $\mathrm{G}_{\mathrm{s}}$ (XLas) and, truncated proteins (XLN1, XLN1b, truncated XLas). The Nesp55 protein is encoded by a single upstream Nesp exon. Nespas and exon 1A transcripts produce non-coding RNAs. Asterisks indicate stop codons (A) Intron-exon organization. Neither exons (coding regions, colored; noncoding regions, striped) nor introns (interbox distances) are in scale; however, their relative positions reflect their positions in the genome.

(B) Transcripts and their translation products (Figure modified from reference Plagge et. al 2004, Holmes et. al. 2003, Weinstein et al. 2001 and Abramowitz et.al. 2004.) 
As originally described (Kozasa, Itoh et al. 1988), the Gnas locus encodes the $\alpha$ subunit of the stimulatory guanine nucleotide-binding protein $G \alpha_{s}$, as well as NESP55, a chromogranin-like neuroendocrine secretory protein (Hayward, Moran et al. 1998), and XLas, a large $\mathrm{G} \alpha_{\mathrm{s}}$ variant (Kehlenbach, Matthey et al. 1994; Hayward, Moran et al. 1998). In addition, the GNAS locus yields two, paternally derived, noncoding RNAs: the A/B transcript (also called 1A) (Liu, Yu et al. 2000), and the antisence (AS) transcript (called Nespas in mice) (Wroe, Kelsey et al. 2000).

The canonical Gnas consists of 13 exons in human and 12 exons in mouse and it encodes the $\alpha$ subunit of the $G \alpha_{s}$. G $\alpha_{s}$ is an essential intermediate in growth, differentiation and homeostatic pathways and is biallelically expressed in most tissues (Hayward, Moran et al. 1998) (see Figure 1.2).

$\mathrm{G}_{\mathrm{s}}$ exist as two splice variants, GasL (394 aa) and GasS (379 aa) (Seifert, WenzelSeifert et al. 1998; Abramowitz, Grenet et al. 2004) depending on the inclusion or not of the 15 amino acids exon 3. The 15 amino acid insert in the Gs $\alpha \mathrm{L}$ is localized between the Ras-like domain and the $\alpha$-helical domain (see Figure 1.1), a position in which the guanine nucleotide-binding site is embedded. In fact it has been show that GasL releases GDP twice as fast as GasS. This structural difference, between the two $\mathrm{G}_{\mathrm{s}}$ splice variants (GasL and GasS), has important consequences for the functional properties of a GPCR. For example $\beta 2$-adrenoreceptor fused to GasL exhibits higher apparent constitutive (agonist-independent) activity than the $\beta 2 \mathrm{AR}$ fused to GasS (Seifert, Wenzel-Seifert et al. 1998; Seifert 2001; Wenzel-Seifert, Kelley et al. 2001). The distribution of long (GasL) and short (GasS) variants of the $\alpha$ subunit of the stimulatory $\mathrm{G}$ protein $\left(\mathrm{G} \alpha_{\mathrm{s}}\right)$ change under a wide range of metabolic conditions, such as cellular differentiation, ontogenetic development and ageing (Novotny and Svoboda 1998). These distributional differences suggest that these alternative $G \alpha_{s}$ isoforms have distinct roles in signaling (Jones, Masters et al. 1990).

GasL and GasS proteins have been reported to migrate in polyacrylamide gels with apparent values of $52 \mathrm{kDa}$ and $45 \mathrm{kDa}$ by some authors (Jones and Reed 1987), or 45 $\mathrm{kDa}$ and $42 \mathrm{kDa}$ by others (Milligan, Mitchell et al. 1990; McFarlane-Anderson, Bailly et al. 1992), depending on the materials and experimental conditions used (Novotny and Svoboda 1998). 
Another neural-specific splice variant is the GsaN1. Exon N1 is an alternative terminal exon between exons 3 and 4 (see Figure 1.2). Splicing to exon N1 leads to the generation of a truncated transcript (GasN1) which does not encode full-length $\mathrm{G} \alpha_{\mathrm{s}}$ (Liu, Yu et al. 2000), there importance, if any, is unknown (Plagge, Gordon et al. 2004).

A large variant of $\mathrm{G} \alpha_{\mathrm{s}}$, termed XLas (for extra large), is derived from GNAS through the use of an alternative promoter and first exon that splices onto the common exon 2. XLas is expressed only from the paternal allele (Hayward, Moran et al. 1998; Hayward and Bonthron 2000) and have a molecular mass of 78 kDa (Klemke, Pasolli et al. 2000; Pasolli, Klemke et al. 2000). The C-terminal domain of XL $\alpha$ s is identical to $\mathrm{G} \alpha_{\mathrm{s}}$ and is encoded by exons 2-13 (41 kDa) of the $\mathrm{G} \alpha_{\mathrm{s}}$ gene, and, hence, contains most of the functional domains of $\mathrm{G} \alpha_{\mathrm{s}}$ including receptor and effector binding sites (Kehlenbach, Matthey et al. 1994). The long aminoterminal extension (37 kDa) is encoded by XLas exon of the $\mathrm{G} \alpha_{\mathrm{s}}$ gene. While RT-PCR experiments suggest that XLas is widely distributed, Northern analysis, immunoblotting, and in situ hybridization experiments demonstrate that XLas expression is limited to neural and endocrine tissue (Kehlenbach, Matthey et al. 1994; Pasolli, Klemke et al. 2000; Pasolli and Huttner 2001). XLas shares many, but not all, functional properties of $\mathrm{G} \alpha_{\mathrm{s}}$. It forms a heterotrimer with $\beta \gamma$ subunits; it binds GTP and undergoes a conformational change upon GTP binding; it activates, when in the GTP state, adenylyl cyclase (Klemke, Pasolli et al. 2000; Bastepe, Gunes et al. 2002) and mediate receptor-stimulated cAMP production (Klemke, Pasolli et al. 2000; Bastepe, Gunes et al. 2002). However, several different methods failed to demonstrate efficient coupling of XLas to different G protein coupled receptors (Klemke, Pasolli et al. 2000). Recent findings indicate that XLas, at least in vitro, is capable of functionally coupling to receptors that normally act via $\mathrm{G} \alpha_{\mathrm{s}}$ (Bastepe, Gunes et al. 2002). Thus, the biological role(s) of XLas within the cell remains obscure. Some findings show that XLas (or possibly XLN1) appears to play a primary role as a negative regulator of sympathetic nervous system activity or that the alternative truncated Gnasxl product XLN1 is a dominant-negative inhibitor of $G \alpha_{\mathrm{s}}$ signaling. (Xie, Plagge et al. 2006). In addition XLas and $\mathrm{G} \alpha_{\mathrm{s}}$ exert antagonistic functions (Plagge, Gordon et al. 2004). 
The XLas promoter generates also at least three additional transcripts. The neuralspecific truncated form of XLas (XLN1) produced by splicing to exon N1 (Pasolli, Klemke et al. 2000). It remains unknown whether the resultant truncated protein has any biological function or it can act as a dominant negative inhibitor of $\mathrm{G} \alpha_{\mathrm{s}}$ or XLas signaling (Xie, Plagge et al. 2006).

In addition two small exons of 91 and $67 \mathrm{bp}$ in length (referred to as A20 and A21) downstream of the XLas exon, express two extra truncated forms of XLas: XLN1a and XLN1b (Weinstein, Yu et al. 2001). While most XLas transcripts do not contain exons A20 and A21, a small proportion of XLas transcripts have A20 alone (Pasolli, Klemke et al. 2000) or both A20 and A21 (Hayward and Bonthron 2000) (see Figure 1.2). A role for these transcripts, if any, remains to be determined (Weinstein, Yu et al. 2001).

Another GNAS protein product is the neuroendocrine secretory protein 55 (Nesp55), a chromogranin-like polypeptide (Hayward, Moran et al. 1998). Nesp55 is expressed specifically in endocrine cells and the nervous system, from the maternal GNAS allele (Hayward, Moran et al. 1998; Bastepe, Frohlich et al. 2005). Nesp55 has a predicted size of approximately $27-29 \mathrm{kDa}$, which due to addition of keratin sulfate glycosaminoglycan chains, appears on immunoblots with a molecular mass of 55 $\mathrm{kDa}$. The entire coding sequence for NESP55 is contained within the upstream exon, and therefore $\mathrm{G} \alpha_{\mathrm{s}}$ exons 2-13 are within the 3'-untranslated region of the Nesp55 transcripts (Hayward, Moran et al. 1998). Nesp imprinting is established later in development, either by the action of paternal antisense Nespas transcripts or other mechanisms (Liu, Chen et al. 2005). The function of Nesp55 is not well understood, but it is regarded as a marker for the constitutive secretory pathway (Chen, Perrin et al. 2005).

In addition, there are paternally expressed, non-coding antisense transcripts, Nespas (Wroe, Kelsey et al. 2000), that start approximately $2 \mathrm{~kb}$ upstream of the Gnasxl initiation site (Abramowitz, Grenet et al. 2004) and overlap the Nesp protein coding exon. Nespas function as a switch to enhance Gnasxl expression and to repress Gnas expression on the paternal allele (Williamson, Turner et al. 2006).

Further analysis of the locus has revealed the presence of additional transcripts, which lack coding potential. An alternative first exon (variously called exon 1A or exon A/B) had been identified upstream of exon 1. This exon generates ubiquitously 
expressed transcripts, expressed only from the paternal allele, that are presumed to be untranslated (Liu, Yu et al. 2000; Weinstein, Chen et al. 2002).

It is possible that the transcript level of exon $1 \mathrm{~A}$ is important in modulating that of Gnas. Recent research shows that the 1 A region can suppress $G \alpha_{\mathrm{s}}$ expression from the paternal allele in a tissue-specific manner (Liu, Chen et al. 2005).

Additional complexity arises because the XL $\alpha$ s-coding transcript contains a second overlapping and conserved ORF (open reading frame), which encodes a completely unrelated and paternally expressed protein termed Alex (Freson, Jaeken et al. 2003; Plagge, Gordon et al. 2004). Alex has the ability to interact with XLas, and inhibits its adenylyl cyclase-stimulating function (Freson, Jaeken et al. 2003; Plagge, Gordon et al. 2004).

\subsection{G protein pathways}

$\mathrm{G}$ protein coupled receptors produce their physiological effects, as the name indicates, via interaction with $\mathrm{G}$ proteins (Heterotrimeric and small $\mathrm{G}$ proteins). The complexity of GPCR signaling raise through the G protein-dependent and G protein-independent signaling (see chapter 1.2.5) but also through cross-talk between G protein coupled receptors and their intracellular second messenger pathways. Cross-talk between different pathways may occur at the level of receptors, $G$ proteins, effectors or second messengers and may serve to fine-tune cell signaling.

$\mathrm{G}$ proteins are so-named because of their ability to bind the guanine nucleotides, guanosine triphosphate (GTP) and guanosine diphosphate (GDP). There are two families of $G$ proteins.

The large family of 'small' G proteins or small GTPases, which lack $\beta \gamma$ subunits, includes the Ras family (signal transduction), the Rho/Rac family (cytoskeleton), the $\mathrm{Rab}$ and Sar1/Arf families (vescicle trafficking), and the Ran family (nuclear import/export) (Takai, Kaibuchi et al. 1994).

The second $\mathrm{G}$ protein family is the membrane-associated heterotrimeric $\mathrm{G}$ proteins or 'large' G proteins. These proteins are activated by $\mathrm{G}$ protein coupled receptors and are made up of alpha $(\alpha)$, beta $(\beta)$ and gamma $(\gamma)$ subunits. 


\subsubsection{Second messenger signaling}

The heterotrimeric $\mathrm{G}$ protein activation produces cellular responses through a variety of second messenger cascades (second messenger pathways). Four major types of $\mathrm{G}$ proteins, $\mathrm{G} \alpha_{\mathrm{s}}, \mathrm{G} \alpha_{\mathrm{i} / \mathrm{o}}, \mathrm{G} \alpha_{\mathrm{q}}$, and $\mathrm{G} \alpha_{12}$, are involved in transduction of signals produced by neurotransmitter binding, and for each one of them exists multiple subtypes.

In G-protein-mediated pathways (Gilman 1987), the hormone, neurotransmitter or drugs (first messenger) binding induces conformational change of the receptor, which induces dissociation of trimeric $\mathrm{G}$ protein-complex (non-active) into the free (active)

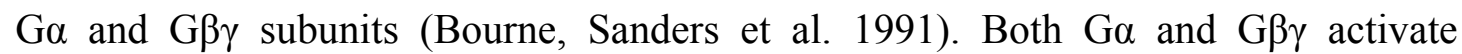
directly (Matsuda, Lee et al. 1992; Lu, Lee et al. 1999; Akam, Challiss et al. 2001; Dascal 2001) or indirectly a great number of enzyme activities (effectors) or ionic channels.

The $\beta \gamma$ subunits released from the G-protein-receptor interaction can direct regulate several voltage-dependent $\mathrm{Ca}^{2+}$ channels and the G-protein-activated $\mathrm{K}^{+}$channels (GIRK). The best established example of this type of mechanism in brain is the coupling of many types of receptors, via subtypes of $\mathrm{G} \alpha_{0}$ and $G \alpha_{i}$ in many types of neurons, to the activation of an inward rectifying $\mathrm{K}^{+}$channel and to the inhibition of a voltage-dependent $\mathrm{Ca}^{2+}$ channel, actions that hyperpolarize cells.

The activation of the $G \alpha$ and $G \beta \gamma$ subunits leads to the activation or inhibition of a variety of second messengers such as cyclic adenosine monophosphate (cAMP), cyclic guanosine monophosphate (cGMP), diacylglycerol (DAG), inositol triphosphate (IP3), arachidonic acid, in addition to changes in intracellular calcium levels as well as opening and closing of a variety of ion channels (Kozasa 2001; Marinissen and Gutkind 2001; Offermanns 2003). Which particular second messenger pathway is activated depends on the receptor $G$ protein coupling and is receptor subtype specific. According to the type of the second messenger, there are five main second messenger pathways:

- $\quad$ cAMP-mediated signaling

- IP3/DAG-mediated signaling and

- $\quad \mathrm{Ca}^{2+}$-mediated signaling

- $\quad$ arachidonic acid-mediated signaling

- $\quad$ NO-cGMP-mediated signaling 


\subsubsection{1 cAMP-mediated signaling}

Cyclic adenosine monophosphate (cAMP) is the first characterized second messenger (Walsh, Perkins et al. 1968; Sutherland 1972). In response to receptor activation, $\mathrm{G}_{\mathrm{s}}$ and $\mathrm{G} \alpha_{\mathrm{i} / \mathrm{o}}$ proteins regulate the stimulation or inhibition of the enzyme adenylyl cyclase respectively, which then synthesise then the second messenger cAMP from cytosolic ATP (Reithmann, Gierschik et al. 1990). The main effector for cAMP remains the cyclic AMP-dependent protein kinase (PKA) but recent reports show that not all effects of cAMP are mediated by PKA (Dremier, Pohl et al. 1997). Other targets of cAMP are the cyclic-nucleotide-gated ion channels and the GTP-exchange protein EPAC which specifically activate the monomeric G protein Rap (de Rooij, Zwartkruis et al. 1998; Kawasaki, Springett et al. 1998). Rap links the $G \alpha_{\mathrm{s}}$ signals to activation of mitogen-activated protein kinase (MAPK) signaling modules. PKA remains as the primary effector of cAMP. Increased level of cAMP activates the PKA which phosphorylates then specific serine or threonine residues on multiple target proteins and activate them. Some of the molecules regulated by PKA are: transcription factors, chromosomal proteins, receptors, ion channels and enzymes.

\subsubsection{Other second messenger signaling pathways}

\section{- IP3/DAG-mediated signaling}

The activation of phospholipase C (PLC) is mediated predominantly by $\mathrm{G} \alpha_{\mathrm{q}}$ proteins in response to receptor activation, although recent reports have show that $G \alpha_{i}$ and $G \alpha_{0}$ may also be involved in some cell types (Murthy, Zhou et al. 2004). PLC hydrolyses a lipid phosphatidylinositol-4,5-bisphosphate (PIP2) in the plasma membrane, producing inositol trisphosphate (IP3) and diacylglycerol (DAG) (see figure 1.3). IP3 and DAG are the second messengers for many growth factors, hormones, and neurotransmitters and they can also act directly on ion channels (Perraud, Fleig et al. 2001; Tesfai, Brereton et al. 2001).

\section{- $\mathrm{Ca}^{2+}$-mediated signaling}

Calcium is involved in the regulation of almost all kinds of pathways. Activation of neurotransmitter receptors can alter the flux of extracellular $\mathrm{Ca}^{2+}$ into neurons or can regulate release of $\mathrm{Ca}^{2+}$ from intracellular stores. 


\section{- Arachidonic acid-mediated signaling}

Arachidonic acid (AA) is involved in synaptic transmission, induction of a variety of signal transduction pathways and stimulation of neuronal damage (Katsuki and Okuda 1995). There are at least three phospholipases which generate free arachidonic acid (AA), through calcium or G-protein-dependent mechanisms (Burch 1989): PLA PLC, and PLD. Recent studies have shown that all of them may be activated by neurotransmitters (Balsinde, Winstead et al. 2002).

\section{- NO/cGMP-mediated signaling}

The NO/cGMP signaling cascade is of importance in the nervous and cardiovascular systems, where it controls modulation of synaptic transmission, and smooth muscle relaxation. The gas nitric oxide (NO) acts as neurotransmitter and has also a neuromodulatory role (Garthwaite and Boulton 1995). It acts mainly through the activation of a soluble guanylate cyclase enzyme, which when activated; produce the second messenger cyclic guanosine monophosphate (cGMP). Studies have shown that NO can also affect directly ion channel activity (Bolotina, Najibi et al. 1994).

\subsubsection{Non second messenger signaling cascades/ MAPK}

There are at least three distinct MAP kinase signal transduction pathways in mammalian cells, each named after the particular MAPK associated with it: ERK, JNK, and p38. MAPK (Mitogen-Activated Protein Kinase) signaling pathways modulate many cellular events including: regulation of embryonic development, cell movement and apoptosis, as well as cell and neuronal differentiation.

\subsubsection{Cross-talk between GPCR pathways}

The term cross-talks refers to the phenomenon that signal components can be shared between different signal pathways and activate multiple responses in the cell. It is known that signaling pathways do not operate in isolation but may regulate and be regulated by one another and so form high complex networks. 


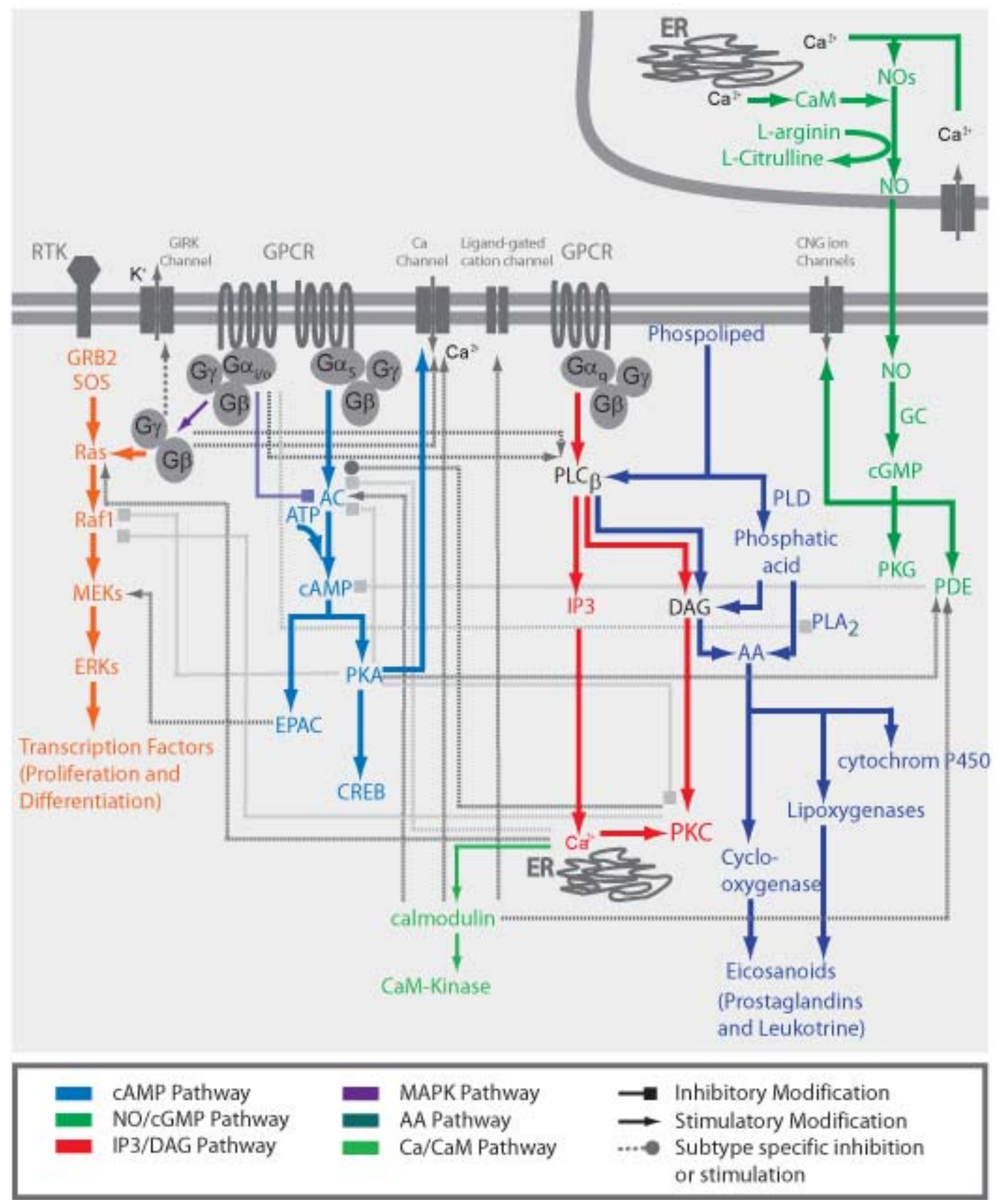

Figure 1.3. G protein-mediated signaling system. This schematic diagram shows the basic pathways and their interactions. This graph is only a first-level representation without many details. The cAMP (blue), IP3/DAG (red), $\mathrm{Ca} / \mathrm{CaM}$ (green), Arachidonic Acid (dark blue), NO/cGMP (dark green), MAPK (orange) pathways are shown together with their interconnections (dark gray for stimulation and gray for inhibition). The possible routes are explained in the text. AC, adenylyl cyclase; PLC, phospholipase C; cAMP, cyclic adenosine monophosphate; IP3, inositol-1,4,5 tris-phoshate; DAG, diacylglycerol; PKC, C kinase; PKA, protein kinase A; ER, endoplasmatic reticulum; cGMP, cyclic guanosine monophosphate; NO, nitric oxide; CaM, calmodulin; PDE, phosphodiesterase; MAPK, MitogenActivated Protein Kinase. 
For example cAMP can act through PKA to produce short-term effects on channel functions, and through Rap and MAPK to regulate gene expression and produce longterm effects (Bos, de Rooij et al. 2001); or the $\beta \gamma$ from the heterotrimeric Gi proteins couples indirectly to the small GTPase Ras and activates the MAPK pathway and through direct interaction regulates the PLC $\beta$ (IP3/DAG Pathway), $\mathrm{K}^{+}$channels, adenylyl cyclase (cAMP pathway) and phosphatidylinositol 3-kinase (Neves, Ram et al. 2002). Figure 1.3 shows the basic pathways and their interactions. Although the map appears quite complex, this is only a first-level representation, where multiple isoforms of the proteins and many more details are not shown.

There are many additional factors which influence the type of the interconnection. Thus, investigations have shown that the subtype of the proteins (e.g. PKC, AC, PLC, $\mathrm{G} \beta, \mathrm{G} \gamma$ ) which take part in the pathways play also an important role. There are about 10 protein kinase $\mathrm{C}(\mathrm{PKC}), 13$ Phospholipase $\mathrm{C}$ (PLC) and nine known adenylate cyclase (AC) isoforms and each of them could lead to a different path (Watts and Neve 2005). For example, in the case of AC; CaM can activate AC1 and AC8; PKC activates AC2 and inhibits AC4 (Nasman, Kukkonen et al. 2002; Sunahara and Taussig 2002). Other factors that influence the cross-talks are the type of the ligand, the type of the tissue, the age, the cell type and many more. In addition there are also differences based on which model system was used for the pathway research. For example in transfected COS and HeLa cell lines the 5HT 1A receptor interacts 100 times more potently through the $G \alpha_{i}$ pathway (AC inhibition) than through the $G \alpha_{q}$ (PLC regulation). In other cell lines, the 5HT 1A receptor interacts equal through the $\mathrm{G \alpha}_{\mathrm{i}^{-}}$and $\mathrm{G} \alpha_{\mathrm{q}^{-}}$pathways and in intact cells interact also through the arachidonic acid pathway (Raymond, Mukhin et al. 1999).

Another example is that the hippocampal corticotropin-releasing factor (CRF) receptors from $\mathrm{BALB} / \mathrm{c}$ mice interact with $\mathrm{G} \alpha_{\mathrm{q} / 11}$, but in $\mathrm{C} 57 \mathrm{BL} / 6 \mathrm{~N}$ mice the CRF receptors are also coupled to $\mathrm{G} \alpha_{\mathrm{s}}, \mathrm{G} \alpha_{\mathrm{q} / 11}$ and $\mathrm{G} \alpha_{\mathrm{i}}$ (Blank, Nijholt et al. 2003).

Thus, the individual signaling mechanisms which are most frequently studied in isolation can show all kind of possible connections, but only the in vivo interactions from certain region and organisms, could give a canonical connection map. 


\subsection{GABA and its receptor system}

$\gamma$-Aminobutyric acid (GABA) is the major inhibitory neurotransmitter in the vertebrate central nervous system, first described in the mammalian brain over 50 years ago (Awapara, Landua et al. 1950; Roberts and Frankel 1950).

GABA regulates, in the immature brain, brain morphogenesis, such as changes in cell proliferation, cell migration, axonal growth, synapse formation, steroid-mediated sexual differentiation and cell death (Belhage, Hansen et al. 1998; Kardos 1999; Varju, Katarova et al. 2001; Ben-Ari 2002; Owens and Kriegstein 2002).

There are two major classes of GABA receptors: metabotropic $\mathrm{GABA}_{B}$ receptors, which produce slow prolonged inhibitory signals and ionotropic $\mathrm{GABA}_{\mathrm{A}}$ (including $\mathrm{GABA}_{\mathrm{C}}$ ) receptors, which produce fast synaptic inhibition (Chebib and Johnston 1999; Bormann 2000).

The ionotropic $\gamma$-Aminobutyric acid type $A\left(\mathrm{GABA}_{\mathrm{A}}\right)$ receptor is a chloride-selective ion channel. Activation of postsynaptic $\mathrm{GABA}_{\mathrm{A}}$ receptor leads to an influx of chloride ions into the postsynaptic cytoplasm and the resulting hyperpolarization of the postsynaptic membrane inhibits the postsynaptic neuron. In contrast to the inhibitory action of $\mathrm{GABA}$ on mature neurons, $\mathrm{GABA}_{\mathrm{A}}$ receptors exert in immature neurons excitatory actions (Ganguly, Schinder et al. 2001; Hubner, Stein et al. 2001). GABA receptors are composed of five subunits in a heteropentameric manner. The most common formation contains two $\alpha$, one or two $\beta$, and one or two $\gamma$ subunits, with potential substitution of $\varepsilon$ or $\delta$ for the $\gamma$ subunit (Benke, Fritschy et al. 1994; Baumann, Baur et al. 2001; Klausberger, Sarto et al. 2001). There are at least 16 different $\mathrm{GABA}_{\mathrm{A}} \mathrm{R}$ subunits grouped together based on their sequence homology, $\alpha$ (1-6), $\beta(1-3), \gamma(1-3), \delta, \varepsilon, \theta$, and $\pi$ (Mehta and Ticku 1999) with a protein size of approximately $55 \mathrm{kDa}$. Specific $\mathrm{GABA}_{\mathrm{A}} \mathrm{R}$ subunit composition has been associated with certain phenotypes such as anxiety, aggression and learning (Delaney and Sah 1999; Rudolph, Crestani et al. 1999; Collinson, Kuenzi et al. 2002).

$\mathrm{GABA}_{\mathrm{A}}$ receptors are targets of a variety of pharmacologically and clinically important drugs, such as benzodiazepines, barbiturates (Ito, Suzuki et al. 1996), ethanol (Celentano, Gibbs et al. 1988), neurosteroids (Harrison and Simmonds 1984), insecticides, and some general anesthetics (Sieghart 2000; Fritschy and Brunig 2003). The pharmacological and biophysical properties of the $\mathrm{GABA}_{\mathrm{A}}$ receptors are 
primarily determined by their subunit composition (Hevers and Luddens 1998; Mohler, Benke et al. 2001; Luscher and Keller 2004; Rudolph and Mohler 2004). Thus, slight variations in $\mathrm{GABA}_{\mathrm{A}}$ receptor subunits composition could contribute to differential behaviour.

The recent identified type of the GABA receptors is the $\mathrm{GABA}_{C}$. Although $\mathrm{GABA}_{\mathrm{A}}$ and $\mathrm{GABA}_{\mathrm{C}}$ receptors are both ionotropic receptors and linked to chloride channels, the $G_{A B A}$ receptors differ from the $G_{A B A}$ and $G_{A B A}$ receptors in their pharmacological and biophysical properties.

They are insensitive to $\mathrm{GABA}_{\mathrm{A}}$-antagonist bicuculline and $\mathrm{GABA}_{\mathrm{B}}$ agonists and antagonist (baclofen and saclofen) (Drew, Johnston et al. 1984), as well as to known $\mathrm{GABA}_{\mathrm{A}}$ modulators like benzodiazepines, barbiturates, and neurosteroids (Bormann and Feigenspan 1995). They lack prominent desensitisation, and they activate and deactivate more slowly than $\mathrm{GABA}_{\mathrm{A}}$ receptors.

$\mathrm{GABA}_{\mathrm{C}}$ receptors are pentamers (Amin and Weiss 1996), composed of GABA $\rho$ subunits (Qian et al., 1997a; Enz et al., 1995, 1996) and they are expressed in many brain regions, with prominent distributions on retinal neurons (Sivilotti and Nistri 1991; Boue-Grabot, Roudbaraki et al. 1998; Wegelius, Pasternack et al. 1998; Enz and Cutting 1999).

\subsection{The GABA $\mathrm{G}_{B}$ receptors}

The metabotropic $\mathrm{GABA}_{\mathrm{B}}$ receptors were first pharmacologically distinguished by Hill and Bowery in 1981 as a bicuculline-insensitive, baclofen ( $\beta$-chlorophenyl GABA)-sensitive GABA receptor widely expressed in the mammalian central nervous system (Hill and Bowery 1981). However the $\mathrm{GABA}_{\mathrm{B}}$ receptor was cloned many years later by Bettler and colleagues (Kaupmann, Huggel et al. 1997), a decade after the $\mathrm{GABA}_{\mathrm{A}}$ receptor (Schofield, Darlison et al. 1987). Since then many agonist and antagonist have been developed for the $\mathrm{GABA}_{\mathrm{B}}$. Phaclofen, saclofen and 2hydroxysaclofen were the first described antagonists (Kerr, Ong et al. 1987; Kerr, Ong et al. 1988), followed by a big variety of antagonists CGP46381, CGP54626, CGP 52432, CGP35348, CGP52432 (Froestl, Bettler et al. 1999). 
$\mathrm{GABA}_{\mathrm{B}}$ exists as heterodimer with the subunits $\mathrm{GABA}_{\mathrm{B}} \mathrm{R} 1$ and $\mathrm{GABA}_{\mathrm{B}} \mathrm{R} 2$ (Jones, Borowsky et al. 1998; Kaupmann, Malitschek et al. 1998; White, Wise et al. 1998; Martin, Russek et al. 1999) which are formed due to alternative splicing (Kuner, Kohr et al. 1999). Both subunits consist of seven transmembrane spanning proteins.

Heterodimer $\mathrm{GABA}_{\mathrm{B}}$ receptors are present at both presynaptic and postsynaptic sites (Chebib and Johnston 1999; Couve, Moss et al. 2000) where they mediate slow synaptic inhibition in the central nervous system. They couple to heterotrimeric $G$ proteins $\left(\mathrm{G}_{\mathrm{i}}\right.$ and $\left.\mathrm{G} \alpha_{\mathrm{o}}\right)$ (Asano, Ui et al. 1985; Hill 1985; Morishita, Kato et al. 1990; Knott, Maguire et al. 1993) and activate second messenger pathways and cause inwardly rectifying $\mathrm{K}^{+}$channels to open and voltage-dependent $\mathrm{Ca}^{2+}$ channels to close (Bettler, Kaupmann et al. 1998; Bowery, Bettler et al. 2002; Calver, Davies et al. 2002; Bettler, Kaupmann et al. 2004). This receptors function as heterodimers. They are composed of a $\mathrm{GABA}_{\mathrm{B} 1}$ and a $\mathrm{GABA}_{\mathrm{B} 2}$ subunits, which are both required for normal receptor functioning (Bettler, Kaupmann et al. 2004).

$\mathrm{GABA}_{\mathrm{B}}$ receptors have been implicated in synaptic inhibition, hippocampal long-term potentiation, short-wave sleep, muscle relaxation, and antinociception (Bettler, Kaupmann et al. 1998; Kaupmann, Malitschek et al. 1998; Bowery and Enna 2000; Cryan and Kaupmann 2005).

\subsubsection{Molecular structure of $\mathrm{GABA}_{\mathrm{B}}$ receptors}

$\mathrm{GABA}_{\mathrm{B}}$ receptors belong to the class $\mathrm{C}$ subfamily of $\mathrm{G}$ protein coupled receptors (Galvez and Pin 2003) together with the vomeronasal (Ryba and Tirindelli 1997), metabotropic glutamate (mGluRs) (Masu, Tanabe et al. 1991), extracellular calciumsensing (CaSR) (Brown, Gamba et al. 1993), and putative taste receptors (Hoon, Adler et al. 1999).

All the members of this subfamily share low sequence similarity and they are composed of seven transmembrane domains with the intracellular loops being responsible for coupling to heterotrimeric $G$ proteins and they are constitutive dimmers.

The distinctive characteristic of this group is the unusually large extracellular domain (ECD), also known as the "venus flytrap domain", that is nearly equal in size to the remaining portion of the protein and it dictates the ligand binding specificity (Galvez, 
Duthey et al. 2001). In contrast to the other class C GPCRs, the $\mathrm{GABA}_{\mathrm{B}}$ receptor is the only one which is a heterodimer composed of two distinct subunits (Marshall, Jones et al. 1999; Mohler and Fritschy 1999; Ng, Clark et al. 1999; Margeta-Mitrovic, Jan et al. 2000; Dean, Higgs et al. 2001; Bowery, Bettler et al. 2002; Calver, Davies et al. 2002; Bettler, Kaupmann et al. 2004; Couve, Restituito et al. 2004) and where the coexpression of both subunits is required for a fully functional $\mathrm{GABA}_{\mathrm{B}}$ receptor (Jones, Borowsky et al. 1998; Kaupmann, Schuler et al. 1998; White, Wise et al. 1998; Kuner, Kohr et al. 1999).

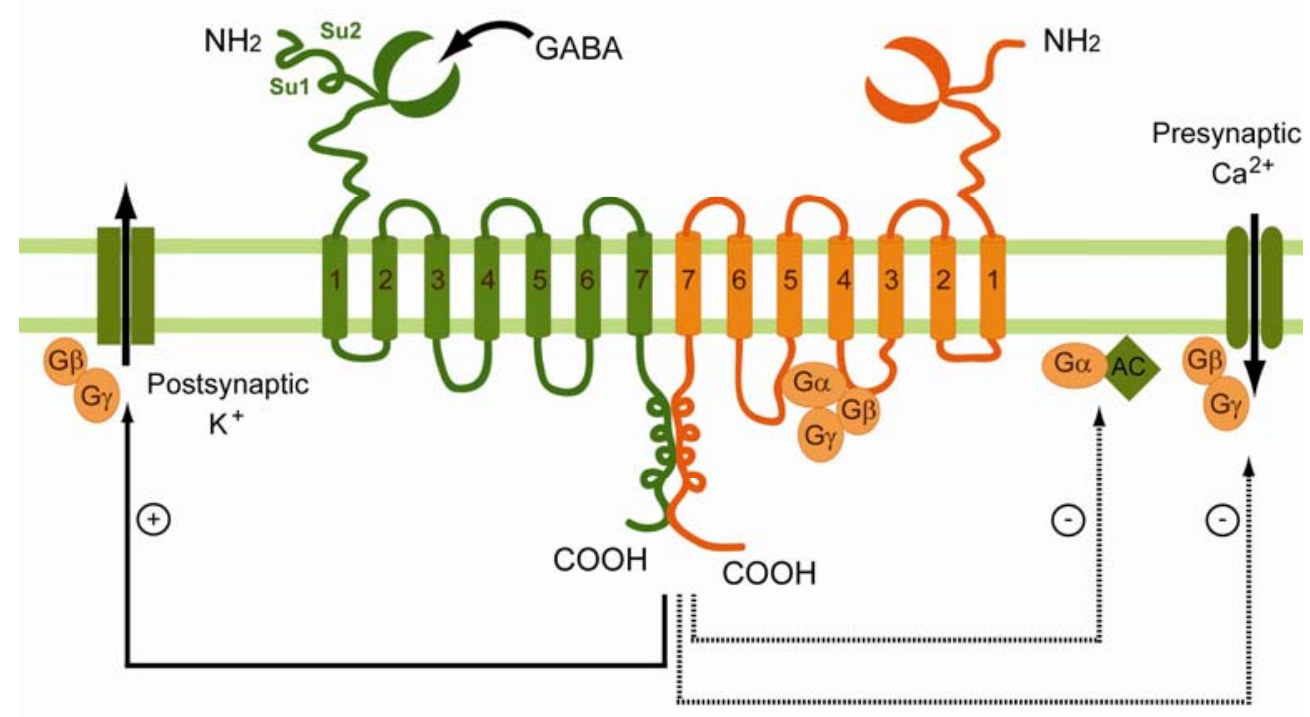

Figure 1.4. Schematic representation of $G_{A B A}$ receptor system indicating the dimeric nature of the structure. The $\mathrm{GABA}_{\mathrm{B} 1 \mathrm{a}}$ subunit contains two Sushi repeats ( $\mathrm{Su} 1$ and $\mathrm{Su} 2$ ) and interact via its $\mathrm{C}$-terminal coiled coil domain with the coiled coil domain of the $\mathrm{GABA}_{\mathrm{B} 2}$ subunit. The $\mathrm{N}$-terminal domain of the $\mathrm{GABA}_{\mathrm{B} 1}$ subunit form two lobes which are able to trap the agonist (Venus Flytrap) (Galvez, Parmentier et al. 1999). Activation of the $\beta \gamma$ subunits leads to activation of postsynaptic $\mathrm{K}^{+}$currents, mediated by inwardly rectifying potassium channels, and to inhibition of presynaptic $\mathrm{Ca}^{2+}$ currents mediated by inactivation of voltage gated calcium channels. Activation of $\mathrm{G} \alpha_{\mathrm{i} / \mathrm{o}}$ subunit results in a negative coupling to adenylate cyclase. $\mathrm{GABA}_{\mathrm{B}} \mathrm{R} 1$, the isoforms $\mathrm{GABA}_{\mathrm{B}} \mathrm{R} 1 \mathrm{a} ; \mathrm{GABA}_{\mathrm{B}} \mathrm{R} 2 ; \alpha, \beta$, and $\gamma$, $\mathrm{G}_{\mathrm{i} / \mathrm{o}}$ protein subunits; AC, adenylate cyclase. Modified from Bettler et al., 1998. 
Although tested $\mathrm{GABA}_{B} \mathrm{R} 1 \mathrm{a}$ and $\mathrm{GABA}_{\mathrm{B}} \mathrm{R} 1 \mathrm{~b}$ were found to be associated with $\mathrm{GABA}_{\mathrm{B}} \mathrm{R} 2$ and the majority of the $\mathrm{GABA}_{\mathrm{B}}$ receptors appear to be heteromers (Benke, Honer et al. 1999; Franek, Pagano et al. 1999).

However, there is evidence that $\mathrm{GABA}_{B} \mathrm{R} 1 \mathrm{a}$ and $\mathrm{GABA}_{\mathrm{B}} \mathrm{R} 1 \mathrm{~b}$ alone are able to couple to $\mathrm{K}^{+}$channels or adenylyl cyclase, although at low efficiency (Kaupmann, Huggel et al. 1997; Kaupmann, Schuler et al. 1998) and that GABA $_{B} R 2$ expressed in HEK 293 cells can inhibit forskolin-stimulated cAMP production in the presence of GABA (Kuner, Kohr et al. 1999; Urwyler, Mosbacher et al. 2001). Thus, GABA $\mathrm{B}$ receptors with monomeric or diverse, yet unknown, heteromeric structures may occur in vivo (Benke, Honer et al. 1999). CGP7930 is described as a positive allosteric regulator of the $\mathrm{GABA}_{\mathrm{B}}$ receptor.

Both subunits, GABA ${ }_{B}$ R1 (Kaupmann, Huggel et al. 1997) and GABA ${ }_{B}$ R2 (Jones, Borowsky et al. 1998; Kaupmann, Malitschek et al. 1998; White, Wise et al. 1998; Kuner, Kohr et al. 1999; Martin, Russek et al. 1999; Ng, Clark et al. 1999) of the $\gamma$ Aminobutyric acid type $\mathrm{B}\left(\mathrm{GABA}_{\mathrm{B}}\right)$ receptor consist of three main regions: an extracellular domain (ECD, N-terminal extracellular domain); a heptahelical domain composed of seven transmembrane $\alpha$-helices (TMD) and loops and the intracellular C-terminal domain (ICD, C-terminal domain) (Kaupmann, Huggel et al. 1997). The $\mathrm{GABA}_{\mathrm{B} 2}$ protein has $54 \%$ similarity and $35 \%$ homology to GABA $\mathrm{B} 1$ (Jones, Borowsky et al. 1998; White, Wise et al. 1998; Kuner, Kohr et al. 1999; Martin, Russek et al. 1999; Ng, Clark et al. 1999).

Whereas $G_{A B A} R 1$ contain the ligand binding site, $G A B A_{B} R 2$ contains all the molecular determinants for $G$ protein coupling. $G_{A B A} R 2$ is also necessary for the $\mathrm{GABA}_{B} \mathrm{R} 1$ transportation to the plasma membrane (White, Wise et al. 1998). Through the interaction between $\mathrm{GABA}_{\mathrm{B}} \mathrm{R} 1$ and $\mathrm{GABA}_{\mathrm{B}} \mathrm{R} 2$ at the $\mathrm{C}$-terminal coiled-coil domain $\mathrm{GABA}_{\mathrm{B}} \mathrm{R} 2$ masks the endoplasmic reticulum (ER) retention signal of the $\mathrm{GABA}_{\mathrm{B}} \mathrm{R} 1$ intracellular tail (Margeta-Mitrovic, Jan et al. 2000; Pagano, Rovelli et al. 2001; Grunewald, Schupp et al. 2002; Bettler, Kaupmann et al. 2004; Couve, Restituito et al. 2004) and helps the $\mathrm{GABA}_{\mathrm{B}} \mathrm{R} 1$ subunit to reach the surface associated with the $\mathrm{GABA}_{\mathrm{B}} \mathrm{R} 2$ and be functional (Margeta-Mitrovic, Jan et al. 2000; Calver, Robbins et al. 2001; Pagano, Rovelli et al. 2001). 
Different studies have confirmed the function of the three main regions of the $\mathrm{GABA}_{\mathrm{B} 1}$ and $\mathrm{GABA}_{\mathrm{B} 2}$ subunits.

The $\mathrm{GABA}_{\mathrm{B} 1}-\mathrm{ECD}$ (extracellular domain) is the only determinant for ligand binding (Malitschek et al., 1999), while the ECD of GABA $_{\mathrm{B} 2}$ does not bind to any known ligands (Kniazeff, Galvez et al. 2002) but it is required for full functionality of the native receptor. The closure of the $\mathrm{GABA}_{\mathrm{B} 1}-\mathrm{ECD}$ lobes after ligand binding is sufficient to keep the receptor in its active state (Kunishima, Shimada et al. 2000; Kniazeff, Saintot et al. 2004). It has been demonstrated that the ECD of GABA $A_{B 2}$ acts allosterically to increase agonist affinity for $\mathrm{GABA}_{\mathrm{B} 1}$ by stabilizing the active state of the receptor (Liu, Maurel et al. 2004) and prevents an inhibitory interaction between the ECD and TMD of GABA B $_{1}$ (Galvez, Duthey et al. 2001; Duthey, Caudron et al. 2002; Liu, Maurel et al. 2004; Uezono, Kanaide et al. 2005).

The $\mathrm{GABA}_{\mathrm{B}}$-TMDs (transmembrane domains) are essential for maximum efficiency of $\mathrm{G}$ protein coupling but only the $\mathrm{GABA}_{\mathrm{B} 2}-\mathrm{TMD}$ is absolutely required (Galvez, Duthey et al. 2001; Margeta-Mitrovic, Jan et al. 2001). Specifically, the GABA $A_{B}$ intracellular loops are not necessary for specific $G$ protein coupling of $\mathrm{GABA}_{B}$ receptors but among the four $\mathrm{GABA}_{\mathrm{B} 2}$ intracellular segments, all three loops were essential for GIRK channel coupling (Calver, Robbins et al. 2001; Margeta-Mitrovic, Jan et al. 2001; Margeta-Mitrovic, Jan et al. 2001; Robbins, Calver et al. 2001; Duthey, Caudron et al. 2002; Havlickova, Prezeau et al. 2002). GABA B1 $_{1}$ intracellular loops might be involved in signaling pathways not involving $G$ proteins or in the regulation of subcellular $\mathrm{GABA}_{\mathrm{B}}$ receptor localization, for example through binding with the transcription factors CREB2 and ATFx or other proteins.

The C-terminus domains of $\mathrm{GABA}_{\mathrm{B} 1}$ and $\mathrm{GABA}_{\mathrm{B} 2}$ subunits are important but not a requirement for proper function (Calver, Robbins et al. 2001; Pagano, Rovelli et al. 2001; Grunewald, Schupp et al. 2002), although there may be differences between G $\alpha$ and G $\beta \gamma$ activated signaling cascades (Margeta-Mitrovic, Jan et al. 2001).

\subsection{2 $\mathrm{GABA}_{\mathrm{B}}$ receptor subtypes and their function}

Many splice variants of the $\mathrm{GABA}_{B} \mathrm{R} 1$ and $\mathrm{GABA}_{\mathrm{B}} \mathrm{R} 2$ have been described (Kaupmann, Huggel et al. 1997; Jones, Borowsky et al. 1998; Kaupmann, Malitschek et al. 1998; White, Wise et al. 1998; Pfaff, Malitschek et al. 1999) and various studies predicted pharmacologically distinct $\mathrm{GABA}_{\mathrm{B}}$ receptor subtypes (Enna 2001). 
Initially, two major isoforms of $\mathrm{GABA}_{B} \mathrm{R} 1, \mathrm{GABA}_{\mathrm{B}} \mathrm{R} 1 \mathrm{a}$ and $\mathrm{GABA}_{\mathrm{B}} \mathrm{R} 1 \mathrm{~b}$, have been identified. Since then further splice variants have been observed: the $G_{A B A} R 1 c$ (Isomoto, Kaibara et al. 1998; Pfaff, Malitschek et al. 1999), GABA $A_{B}$ 1d (Poorkhalkali, Juneblad et al. 2000), GABA ${ }_{B} R 1$ e (Schwarz, Barry et al. 2000), $\mathrm{GABA}_{B}$ R1f (Wei, Jia et al. 2001), and $\mathrm{GABA}_{B} R 1 \mathrm{~g}$ (Wei, Jia et al. 2001). Beside variants $1 \mathrm{a}$ and $1 \mathrm{~b}$, for the rest $\mathrm{GABA}_{\mathrm{B}}(\mathrm{c}-\mathrm{g})$ splice variants could not be demonstrated the existence of a protein in vivo or they do not occur across different species (Bowery, Bettler et al. 2002; Bettler, Kaupmann et al. 2004). For example $\mathrm{GABA}_{\mathrm{B}} \mathrm{R} 1 \mathrm{c}$ appears to act as a functional subunit but is expressed only in humans. Splice variants have also been described for $G_{A B A} R 2$. The two transcripts $\mathrm{GABA}_{\mathrm{B} 2 \mathrm{~b}}$ and $\mathrm{GABA}_{\mathrm{B} 2 \mathrm{c}}$ have been proposed to arise from alternative splicing of the $\mathrm{GABA}_{\mathrm{B}} \mathrm{R} 2$ message (Calver, Medhurst et al. 2000; Clark, Mezey et al. 2000). Although no difference in expression or function has been detected for the reported $\mathrm{GABA}_{\mathrm{B}} \mathrm{R} 2 \mathrm{~b}$ or $\mathrm{GABA}_{\mathrm{B}} \mathrm{R} 2 \mathrm{c}$ variants (Martin, Russek et al. 2001). GABA $\mathrm{B}_{2 b}$ and $\mathrm{GABA}_{\mathrm{B} 2 \mathrm{c}}$ transcripts are likely to represent artefacts arising during cDNA synthesis and/or PCR amplification. Therefore, at the present time, there are no confirmed $\mathrm{GABA}_{\mathrm{B} 2}$ splice variants (Bettler, Kaupmann et al. 2004; Steiger, Bandyopadhyay et al. 2004).

The predominant $G_{A B A} R 1$ receptor subtypes are $G_{B B} R 1 a$ and $G_{B} A B A_{B} R 1 b$, both of which combine with the $\mathrm{GABA}_{\mathrm{B} 2}$ subunit to form heterodimers at mainly different subcellular locations (Benke, Honer et al. 1999; Steiger, Bandyopadhyay et al. 2004). $\mathrm{GABA}_{\mathrm{B}} \mathrm{R} 1 \mathrm{a}$ and $\mathrm{GABA}_{\mathrm{B}} \mathrm{R} 1 \mathrm{~b}$ are expressed in the brain by the presence of alternative transcription sites in the $\mathrm{GABA}_{\mathrm{B} 1}$ gene and differential promoter usage (Kaupmann, Huggel et al. 1997; Steiger, Bandyopadhyay et al. 2004).

The human $\mathrm{GABA}_{\mathrm{B}} \mathrm{R} 1$ gene on chromosome 6p21.3 (Grifa, Totaro et al. 1998) is in the genetic locus for neurobehavioral disorders that include schizophrenia, juvenile myoclonic epilepsy and dyslexia (Cryan and Kaupmann 2005). The human $\mathrm{GABA}_{\mathrm{B}} \mathrm{R} 2$ gene on chromosome $9 \mathrm{q} 22.1$ is a candidate gene for hereditary sensory neuropathy type 1 (Martin, Russek et al. 1999; Ng, Clark et al. 1999; Martin, Russek et al. 2001).

Information about the molecular structure of the $\mathrm{GABA}_{\mathrm{B}}$ receptor is only available from human and rat. $\mathrm{GABA}_{\mathrm{B} 1 \mathrm{a}}$ is a protein of 960 amino acids $(120 \mathrm{kDa})$ and $\mathrm{GABA}_{\mathrm{B} 1 \mathrm{~b}}$ is a protein of 844 amino acids (100 kDa) (Kaupmann, Huggel et al. 1997). 
They share the C-terminal amino acids and they differ solely in their $\mathrm{N}$ terminus, where the first 147 residues of $\mathrm{GABA}_{B} \mathrm{R} 1 \mathrm{a}$ are replaced by a sequence of 18 different amino acids in GABA $_{B}$ R1b (Kaupmann, Huggel et al. 1997; Martin, Russek et al. 2001). The $\mathrm{N}$-terminal sequence of the $\mathrm{GABA}_{\mathrm{B}} \mathrm{R} 1 \mathrm{a}$ protein contains two sushi domains (Hawrot, Xiao et al. 1998). These domains are involved in protein-protein interactions used also for cell-cell adhesion (Bettler, Kaupmann et al. 2004). It is suggested that the $\mathrm{GABA}_{\mathrm{B} 1 \mathrm{a}}$ sushi-repeats interact with the extracellular matrix protein fibulin (Blein, Ginham et al. 2004). The pharmacological profile of the $\mathrm{GABA}_{\mathrm{B} 1 \mathrm{a}}$ and $\mathrm{GABA}_{\mathrm{B} 1 \mathrm{~b}}$ splice variants is similar (Kaupmann, Huggel et al. 1997). To date no convincing pharmacological differences have been described to any of the functional $\mathrm{GABA}_{\mathrm{B}}$ splice variants. Although studies by $\mathrm{Ng}$ and colleagues reported that gabapentin acts as an agonist to $\mathrm{GABA}_{\mathrm{B}} \mathrm{R} 1 \mathrm{a}$ but not to $\mathrm{GABA}_{\mathrm{B}} \mathrm{R} 1 \mathrm{~b}(\mathrm{Ng}$, Bertrand et al. 2001), additional experiments in brain slice preparations (Lanneau, Green et al. 2001) or in vivo could not replicate this findings (Jensen, Mosbacher et al. 2002).

Although the pharmacological profile of the two isoforms seems to be similar, the subcellular distribution and their physiological behaviour is different. Studies with rat and human cerebellum and spinal cord show that $\mathrm{GABA}_{B} \mathrm{R} 1 \mathrm{a}$ isoform is localized preferentially at presynaptic sites and the $\mathrm{GABA}_{\mathrm{B}} \mathrm{R} 1 \mathrm{~b}$ appears to be preferentially located postsynaptically (Kaupmann, Schuler et al. 1998; Billinton, Upton et al. 1999; Bischoff, Leonhard et al. 1999; Ritter, Zschuntsch et al. 2004). In different areas of the brain however, $\mathrm{GABA}_{\mathrm{B} 1 \mathrm{~b}}$ protein is located at presynaptic terminals and the $\mathrm{GABA}_{\mathrm{B} 1 \mathrm{a}}$ at the postsynaptic sites (Benke et al., 1999; Princivalle et al., 2001).

In addition recent studies show that the two $\mathrm{GABA}_{\mathrm{B} 1}$ isoforms have also distinct functions in synaptic physiology and behaviour (Perez-Garci, Gassmann et al. 2006); the $\mathrm{GABA}_{\mathrm{B} 1 \mathrm{a}}$ mainly assembles presynaptic heteroreceptors, while $\mathrm{GABA}_{\mathrm{B} 1 \mathrm{~b}}$ receptor mainly mediates postsynaptic inhibition (Huang 2006).

\subsection{3 $\mathrm{GABA}_{\mathrm{B}}$ receptor-mediated signaling}

Downstream effects of $\mathrm{GABA}_{\mathrm{B}}$ receptor activation are mediated by $\mathrm{G}$ proteins (Hill, Bowery et al. 1984; Asano, Ui et al. 1985) and predominantly through coupling to $\mathrm{G}_{\mathrm{i}}$ and $\mathrm{G} \alpha_{\mathrm{o}}$ types of $\mathrm{G}$ proteins (Asano and Ogasawara 1986; Morishita, Kato et al. 1990; Menon-Johansson, Berrow et al. 1993; Greif, Sodickson et al. 2000), although G 
protein independent effects have been also described (Harrison 1990). Through heterotrimeric $G$ proteins the presynaptic $\mathrm{GABA}_{\mathrm{B}} \mathrm{Rs}$ inhibit neurotransmitter release by down-regulating high-voltage activated $\mathrm{Ca}^{2+}$ channels (Mintz and Bean 1993; Kerr and Ong 1995), whereas postsynaptic $\mathrm{GABA}_{\mathrm{B}} \mathrm{Rs}$ activate inwardly rectifying $\mathrm{K}^{+}$ channels (GIRK) (Andrade, Malenka et al. 1986; Misgeld, Bijak et al. 1995) and inhibit adenylyl cyclase (Nishikawa, Hirouchi et al. 1997).

\section{A. Coupling to $\mathrm{K}^{+}$channels}

Postsynaptic $\mathrm{GABA}_{\mathrm{B}}$ receptors activate inwardly rectifying $\mathrm{K}^{+}$channels (GIRK or Kir3), via the $\beta \gamma$ subunits of the $G \alpha_{\mathrm{i} / \mathrm{o}} \mathrm{G}$ proteins (Newberry and Nicoll 1984; Gahwiler and Brown 1985), which induce a slow inhibitory postsynaptic current (IPSC) (Luscher, Jan et al. 1997; Schuler, Luscher et al. 2001). This baclofen stimulated IPSC can be inhibited by the Kir3 channel blocker, barium (Jarolimek, Bijak et al. 1994). There is evidence that $G_{A B A}$ receptors could act also through voltage-gated $\mathrm{K}^{+}$channels (Blaxter, Carlen et al. 1986; Saint, Thomas et al. 1990) and $\mathrm{Ca}^{2+}$-activated $\mathrm{K}^{+}$channels (SK channels) (Blaxter, Carlen et al. 1986; Gerber and Gahwiler 1994). In addition, $\mathrm{GABA}_{\mathrm{B}}$ receptors also activate presynaptic $\mathrm{Ba}^{2+}$ sensitive $\mathrm{K}^{+}$channels (Thompson and Gahwiler 1992) which are composed of different subunits than the postsynaptic channels (Luscher, Jan et al. 1997).

\section{B. Coupling to $\mathrm{Ca}^{2+}$ channels}

The presynaptic $\mathrm{GABA}_{\mathrm{B}}$ receptors are subdivided in autoreceptors and heteroreceptors. The autoreceptors control the GABA release and the heteroreceptors inhibit all other neurotransmitter release (Calver, Davies et al. 2002; Bettler, Kaupmann et al. 2004), including glutamate (Yamada, Saitow et al. 1999; Hirono, Yoshioka et al. 2001), monoamines and many neuropeptides (Bowery, Hill et al. 1980; Bonanno and Raiteri 1993; Morton, Manuel et al. 2001).

Presynaptic $\mathrm{GABA}_{\mathrm{B}}$ receptors inhibit neurotransmitter release by blocking $\mathrm{Ca}^{2+}$ influx via high-voltage activated $\mathrm{Ca}^{2+}$ channels (Mintz and Bean 1993; Poncer, McKinney et al. 1997) through G $\beta \gamma$ subunits of a pertussis toxin-sensitive G proteins (Dascal 2001; Kajikawa, Saitoh et al. 2001; Zamponi 2001) or through a direct modulation of synaptic vesicle priming (Sakaba and Neher 2003). The presynaptic $G_{A B} A_{B}$ receptor 
effect is associated with high-voltage activated $\mathrm{Ca}^{2+}$ channels (Wu and Saggau 1997) of $\mathrm{N}$ type (Cav2.2) and P/Q type (Cav2.1) (Menon-Johansson, Berrow et al. 1993; Mintz and Bean 1993; Amico, Marchetti et al. 1995; Herlitze, Garcia et al. 1996; Poncer, McKinney et al. 1997; Takahashi, Kajikawa et al. 1998; Ikeda and Dunlap 1999). Both types of $\mathrm{Ca}^{2+}$ channels are expressed in presynaptic terminals and were shown to trigger neurotransmitter release (Wu and Saggau 1997).

In addition, inhibition (Maguire, Maple et al. 1989; Amico, Marchetti et al. 1995) or facilitation (Shen and Slaughter 1999) of L-type $\mathrm{Ca}^{2+}$ channels by $\mathrm{GABA}_{\mathrm{B}}$ receptors are also described. This effect was shown to be indirect and to depend on protein kinase $\mathrm{C}(\mathrm{PKC})$ activity. $\mathrm{GABA}_{\mathrm{B}}$ receptors also inhibit or disinhibit T-type $\mathrm{Ca}^{2+}$ channels (Scott and Dolphin 1986; Crunelli and Leresche 1991; Matsushima, Tegner et al. 1993). A postsynaptic inhibition of $\mathrm{Ca}^{2+}$ channels of $\mathrm{N}$ - and P/Q-type by $\mathrm{GABA}_{\mathrm{B}}$ receptors (Harayama, Shibuya et al. 1998) and $G$ protein-independent $\mathrm{GABA}_{\mathrm{B}}$ effects on neurotransmitter release (Harrison 1990) were also postulated.

\section{Coupling to adenylyl cyclase}

Besides modulation of ion channels through $G \beta \gamma$, pre- and postsynaptic $\mathrm{GABA}_{\mathrm{B}}$ receptors activate and inhibit adenylyl cyclase (Hashimoto and Kuriyama 1997; Olianas and Onali 1999; Bowery, Bettler et al. 2002; Calver, Davies et al. 2002) via the $\mathrm{G \alpha}_{\mathrm{i} / \mathrm{o}}$ and $\mathrm{G} \beta \gamma$ subunits (Bowery 1993; Bettler, Kaupmann et al. 2004).

The inhibitory effect on adenylyl cyclase (AC) through activation of $\mathrm{GABA}_{B}$ receptors (Wojcik and Neff 1984) is mediated by $\mathrm{G} \alpha_{i}$ and $\mathrm{G} \alpha_{0}$ proteins ( $\mathrm{Xu}$ and Wojcik 1986; Morishita, Kato et al. 1990; Kaupmann, Huggel et al. 1997). The pertussis toxin-sensitive $\mathrm{G} \alpha$ proteins inhibit AC types I, III, V, and VI (Bettler, Kaupmann et al. 2004) and thus decrease the cAMP levels and the PKA activity, which results in the inhibition of GABA release.

Activation of the $\mathrm{GABA}_{\mathrm{B}}$ receptor can also stimulate adenylyl cyclase types II, IV, and VII, in response to Gas-coupled GPCRs activated by hormones (Kelly and Wagner 1999) and neurotransmitters, such as noradrenaline, vasoactive intestinal peptide, adenosine and prostaglandins (Karbon, Duman et al. 1984; Karbon and Enna 1985; Schaad, Schorderet et al. 1989; Simonds 1999; Bowery and Enna 2000).

Early studies in brain slices have suggested that facilitation of cyclic AMP formation occurs indirectly, as a consequence of phospholipase A2 stimulation by $\mathrm{GABA}_{\mathrm{B}}$ 
receptors and may be mediated by arachidonate or some other fatty acid (Duman, Karbon et al. 1986).

In addition, it is proposed that $\mathrm{GABA}_{\mathrm{B}}$ receptors enhance adenylyl cyclase II and IV activities by a mechanism involving $\beta \gamma$ subunits of $\mathrm{G}_{\mathrm{i} / \mathrm{o}}$. Adenylyl cyclases II and IV are two $\mathrm{AC}$ isoforms which can be stimulated by $\mathrm{G} \alpha_{\mathrm{i} / \mathrm{o}}$ protein $\beta \gamma$ subunits (Tang and Gilman 1992) and it is proposed that $\mathrm{GABA}_{B}$ receptors, by interacting with $\mathrm{G \alpha}_{\mathrm{i} / \mathrm{o}}$ proteins, may promote the release of a sufficiently high amount of $\beta \gamma$ subunits to stimulate type II/IV adenylyl cyclase activities (Tang and Gilman 1992; Olianas and Onali 1999).

It is shown that in specific layers of rat olfactory bulb, a brain area expressing a high level of type II adenylyl cyclase (Feinstein et al., 1991), other $\mathrm{G} \alpha_{\mathrm{i} / \mathrm{o}_{\mathrm{o}}}$-coupled receptors, such as the acetylcholine muscarinic and opioid receptors, stimulate basal adenylyl cyclase activity and potentiate the responses of $\mathrm{G}_{\mathrm{s}}$-linked neurotransmitter receptors (Olianas and Onali 1993; Olianas and Onali 1999).

\subsubsection{Modulation of $\mathrm{GABA}_{B}$ receptor function}

A number of studies have reported many factors which can lead to modulation of $\mathrm{GABA}_{\mathrm{B}}$ receptors such as cross-talks with other receptors or pathways and interaction with $\mathrm{GABA}_{\mathrm{B}} \mathrm{R}$ associate proteins (Karbon, Duman et al. 1984; Karbon and Enna 1985; Duman, Karbon et al. 1986; Schaad, Schorderet et al. 1989; Olianas and Onali 1999; Simonds 1999; Bowery and Enna 2000; Kubota, Katsurabayashi et al. 2003; Balasubramanian, Teissere et al. 2004)

Cross-talks between PKA and PKC pathways which affect GABA release have also been reported. It has been suggested that the PKC cascade has no direct effects on GABA release, but it is involved in GABA release via cross-talk with the cAMP/PKA (Kubota, Katsurabayashi et al. 2003).

The complexity in the modulation of $\mathrm{GABA}_{\mathrm{B}}$ receptor function rise with a number of $\mathrm{GABA}_{\mathrm{B}}$ receptor associated proteins which produce diverse physiological and pharmacological effects. Different studies have demonstrated that both $\mathrm{GABA}_{\mathrm{B} 1}$ and $\mathrm{GABA}_{\mathrm{B} 2}$ subunits associate with other proteins.

One of this proteins is the transcription factor CREB2/ATF4, which interacts directly with the $\mathrm{GABA}_{B} \mathrm{R} 1$, suggesting a novel $\mathrm{G}$ protein independent mechanism of signal 
transduction (Nehring, Horikawa et al. 2000; White, McIllhinney et al. 2000; Vernon, Meyer et al. 2001). CREB, ATF4 and USF have been shown to regulate expression of the $\mathrm{GABA}_{\mathrm{B} 1 \mathrm{a}}$ and $\mathrm{GABA}_{\mathrm{B} 1 \mathrm{~b}}$ receptors (Steiger, Bandyopadhyay et al. 2004). CREB stimulates expression of both $\mathrm{GABA}_{\mathrm{B} 1 \mathrm{a}}$ and $\mathrm{GABA}_{\mathrm{B} 1 \mathrm{~b}}$, USF inhibits expression of $\mathrm{GABA}_{\mathrm{B} 1 \mathrm{~b}}$, and ATF4 which interact with GABA $\mathrm{B} 1 \mathrm{a}$ and R1b (Ritter, Zschuntsch et al. 2004) and stimulates expression of $\mathrm{GABA}_{\mathrm{B} 1 \mathrm{a}}$ but inhibits expression of $\mathrm{GABA}_{\mathrm{B} 1 \mathrm{~b}}$ (Steiger, Bandyopadhyay et al. 2004).

Further more, $\mathrm{GABA}_{\mathrm{B}} \mathrm{R} 1$ is associated with the 14-3-3 proteins, which compete with $\mathrm{GABA}_{\mathrm{B} 2}$ for binding to $\mathrm{GABA}_{\mathrm{B} 1}$ in vivo, something which may regulate $\mathrm{GABA}_{\mathrm{B}}$ receptor heterodimerization (Couve, Kittler et al. 2001). Marlin-1 was proposed to regulate the cellular levels of $\mathrm{GABA}_{\mathrm{B} 2}$ and thereby to affect the number of functional $\mathrm{GABA}_{\mathrm{B}}$ receptors (Couve, Restituito et al. 2004).

The fact that protein fibulin-2 in vitro binds to the two sushi repeats of the GABA $\mathrm{B} 1 \mathrm{a}$, but not to the $\mathrm{GABA}_{\mathrm{B} 1 \mathrm{~b}}$ which lacks the two sushi repeats, provides evidence for the existence of subtype-selective interacting proteins (Blein, Ginham et al. 2004). Another protein which interacts in a subtype specific manner is the transcription factor CHOP, also known as Gadd153, which interacts selectively with $\mathrm{GABA}_{\mathrm{B} 1 \mathrm{a}} / \mathrm{GABA}_{\mathrm{B} 2}$ receptors and results a reduced cell surface expression of the receptor (Sauter, Grampp et al. 2005). A physical interaction between $G_{B A} A_{A}$ and $\mathrm{GABA}_{\mathrm{B}}$ receptor subunits was also reported (Balasubramanian, Teissere et al. 2004). Association of $\mathrm{GABA}_{\mathrm{B} 1}$ with the $\gamma 2 \mathrm{~S}$ subunit of $\mathrm{GABA}_{\mathrm{A}}$ receptors robustly promotes cell surface expression of $\mathrm{GABA}_{\mathrm{B} 1}$ in the absence of $\mathrm{GABA}_{\mathrm{B} 2}$. The cross-talk between $\mathrm{GABA}_{A}$ and $\mathrm{GABA}_{\mathrm{B}}$ subunits regulates $\mathrm{GABA}_{\mathrm{B}}$ receptor trafficking (Bettler and Tiao 2006).

Another protein that interact with $\mathrm{GABA}_{\mathrm{B}} \mathrm{R} 2$ receptors is MUPP-1 which may serve as an adaptor protein, linking $\mathrm{GABA}_{\mathrm{B} 2}$ to various signaling molecules (Milligan and White 2001; Bettler, Kaupmann et al. 2004). NEM-sensitive factor ,or NSF, has been shown to interact with the C-terminal end of GABA B2 $_{2}$ (Bettler, Kaupmann et al. 2004) but also with $\mathrm{GABA}_{\mathrm{A}}$ receptors and possibly provides a structural link between the ionotropic and metabotropic GABA receptor systems. Tamalin is yet another scaffolding protein that interacts with $\mathrm{GABA}_{\mathrm{B}}$, as well as mGlu receptors (Kitano, Kimura et al. 2002). 


\subsection{Changes in the distribution of the GABAergic system}

GABA and its receptors (ionotropic and metabotropic) show particular ontogenetic distribution in different brain areas. Specific GABA receptors subtypes are highly expressed in the embryonic and/or postnatal brain, whereas others are mainly present in the adult brain. These changes in the distribution and composition of the GABA receptor subunits are crucial for normal development of the brain areas (Lujan, Shigemoto et al. 2005). Extended investigations on the developmental changes of $\mathrm{GABA}_{\mathrm{A}}$ receptors demonstrate the influences of GABA receptor subunit alteration. In the adult CNS, GABA is a predominant inhibitory neurotransmitter, whereas in the immature brain serves as an excitatory transmitter (Ben-Ari 2002; Owens and Kriegstein 2002). This switch is associated with a differential expression of $\mathrm{GABA}_{\mathrm{A}}$ receptor subunits.

Although consequence and effects of this differential expression of subunits is not fully understood, it shows that the ontogenetic change in a subunit composition regulates the function of the receptor (Takayama and Inoue 2004; Lujan, Shigemoto et al. 2005). The expression of $\mathrm{GABA}_{\mathrm{B}} \mathrm{Rs}$ in the adult brain is described in many papers, but the functional significance of these receptor during postnatal development is largely unknown (Zhang, Elsen et al. 1999).

\subsubsection{Distribution of $\mathrm{GABA}_{\mathrm{A}}$ receptor variants during brain development}

Findings in animal models demonstrate that $\mathrm{GABA}_{\mathrm{A}} \mathrm{R}$ subunit expression varies across cell types, structural regions, and over the course of brain developments (Gambarana, Beattie et al. 1991; Killisch, Dotti et al. 1991; Laurie, Seeburg et al. 1992; Laurie, Wisden et al. 1992; Wisden, Laurie et al. 1992; Fritschy, Paysan et al. 1994; Gutierrez, Khan et al. 1994; Fritschy and Mohler 1995; Gutierrez, Khan et al. 1996; Gutierrez, Khan et al. 1997; Brunig, Scotti et al. 2002; Wei, Zhang et al. 2003; Lopez-Tellez, Vela et al. 2004; Yu, Wang et al. 2006). Altering subunit composition changes receptor kinetics, pharmacology and physiology, which impacts behaviour (Pirker, Schwarzer et al. 2000). So that light variations in $\mathrm{GABA}_{\mathrm{A}} \mathrm{R}$ subunit composition could contribute to both normal behaviour, as well as pathologic conditions (Brussaard, Kits et al. 1997; Gao, Newman et al. 1999; Porter, Zhang et al. 2005). 
For example specific $\mathrm{GABA}_{\mathrm{A}} \mathrm{R}$ subunit compositions have been associated with certain phenotypes such as anxiety, aggression, learning and memory deficits (Delaney and Sah 1999; Rudolph, Crestani et al. 1999; Collinson, Kuenzi et al. 2002; Armstrong, Sheffield et al. 2003; Miczek, Fish et al. 2003; Ishikawa, Mizukami et al. 2004; Porter, Zhang et al. 2005).

The aging-related changes in the expression patterns of the $\mathrm{GABA}_{\mathrm{A}}$ receptor subunits lead also to functional differences in $\mathrm{GABA}_{\mathrm{A}}$ receptors during ontogeny (MacLennan, Brecha et al. 1991).

Although the subunit distribution of the $\mathrm{GABA}_{\mathrm{A}}$ receptors varies from region to region, we can generally say that the immature brain expresses several subunits, including $\alpha 1, \alpha 2, \alpha 3, \alpha 5, \beta 2$, and $\gamma 2$. Subunits $\alpha 2, \alpha 3$, and $\alpha 5$ were found to decrease with age and in contrast, $\alpha 1, \beta 2$, and $\gamma 2$ levels are maintained or rise with age (Laurie, Wisden et al. 1992; Brooks-Kayal, Jin et al. 1998). $\alpha 1, \beta 2$, and $\gamma 2$ are the predominant subunits in the adult brain (Fritschy and Mohler 1995; Pirker, Schwarzer et al. 2000) and were found throughout the brain, although differences in their distribution were observed. Subunit $\alpha 2, \alpha 3, \alpha 4, \alpha 5, \alpha 6, \gamma 1$, and $\delta$ are more confined to certain brain areas.

Generally, the $\mathrm{GABA}_{\mathrm{A}} \mathrm{R}$ subunit expression is more significant among $\alpha$ subunits than among the other subunits (Bosman, Rosahl et al. 2002), and in the majority of changes involves a developmental decrease in $\alpha 2$ or $\alpha 3$ expression and an increase in $\alpha 1$ expression (Laurie, Seeburg et al. 1992; Fritschy, Paysan et al. 1994; Bosman, Rosahl et al. 2002).

The alpha 1 expression is low at birth, restricted to a few areas, and increases dramatically during the first postnatal weeks. In contrast, the alpha 2 subunit, has a widespread distribution throughout the brain at birth, and disappears from numerous areas soon after the appearance of the alpha 1-subunit.

During a short time window, many individual neurons show a coexistence of both $(\alpha 1$ and $\alpha 2$ ), which indicates that the alpha 1-subunit gradually replaces receptors containing the alpha 2-subunit (MacLennan, Brecha et al. 1991; Laurie, Wisden et al. 1992; Fritschy, Paysan et al. 1994; Gutierrez, Khan et al. 1996; Lopez-Tellez, Vela et al. 2004). 
The $\beta 2, \beta 3$, and $\gamma 2$ subunits, which are a major constituent of $\mathrm{GABA}_{\mathrm{A}}$ receptors in both immature and adult rat brain, show no significant changes in their expression (Fritschy, Paysan et al. 1994).

In the rat pre-Bötzinger complex (PBC) has been shown an aging-related switch in the expression of $\alpha 1$ and $\alpha 3$ subunits. The $\alpha 3$-subunit is at the age of P0 (postnatal day 0 ) at relatively high levels and it decreases with development, whereas the $\alpha 1$-subunit, which is relative low at $\mathrm{P} 0$, increases with age. The expression of $\alpha 2$-subunit is rather constant throughout the postnatal development.

Although there is no direct evidence, it is postulated that the switch from depolarisation to hyperpolarisation during the early brain development is associated with a switch of $\mathrm{GABA}_{\mathrm{A}}$ receptor $\alpha$ subunit composition, which contributes to functional changes in GABA transmission (Liu and Wong-Riley 2006). This excitation-inhibition switch of $\mathrm{GABA}_{\mathrm{A}}$ receptor function takes place in the early postnatal period and depends on the animal species, the brain regions and the type of neurons. In hypothalamic and spinal cord neurons the switch from depolarisation to hyperpolarisation happens between P8 and P12 (Gao and van den Pol 2001), in hippocampal neurons between P8 and P12 (Ben-Ari, Cherubini et al. 1989; Michelson and Wong 1991; Ruano, Araujo et al. 2000), and in brainstem during the first postnatal week (Ritter and Zhang 2000; Marchetti, Pagnotta et al. 2002).

The combination of the $\alpha$ subunit age depended alteration with the $\mathrm{GABA}_{\mathrm{A}}$ receptor functional switch, means that the $\alpha 2$ (or $\alpha 3$ ) composition would contribute to the depolarizing GABA transmission in the neonate, and the $\alpha 1$ composition could contribute to the synaptic inhibition in the adult (Fritschy, Paysan et al. 1994).

In addition, it has been reported that $\mathrm{GABA}_{\mathrm{A}}$ receptors can depolarize also in adult neurons, such as in the CA1 pyramidal neurons (Isomura, Sugimoto et al. 2003), which expresses predominantly $\alpha 2$ subunit (Laurie, Wisden et al. 1992).

\subsubsection{Neurodevelopmental disorder (MECP2)}

Rett syndrome is an X-linked neurodevelopmental disorder caused by mutations in the gene encoding the transcriptional repressor methyl-CpG-binding protein 2 (MeCP2) (Amir, Van den Veyver et al. 1999).

$\mathrm{MeCP} 2$ is expressed widely, but is increasingly expressed during development (Kishi and Macklis 2004). It binds DNA methylated at CpG sites and once bound to DNA it 
regulates transcriptional repression (Shahbazian and Zoghbi 2002). Thus, loss of $\mathrm{MeCP} 2$ function leads to improper gene expression programs.

Rett syndrome affects almost exclusively girls and is usually fatal for males. After a period of apparently normal development (6-18 months), Rett syndrome patients enter a period of regression, characterized by loss of acquired language, acquired microcephaly, autistic manifestations, loss of purposeful hand skills, stereotypic hand movements, gait ataxia, and breathing abnormalities such as hyperventilation and apnea (Coleman, Brubaker et al. 1988; Amir, Van den Veyver et al. 1999; Hagberg 2002; Zoghbi 2005).

Since the availability of mecp2 mutant mice which provides a very good model system for the research of Rett syndrome (Amir, Van den Veyver et al. 1999), many molecular, anatomical or behavioural studies have been done.

It is known that, Rett syndrome is a disorder of abnormal neuronal maturation (Kaufmann, MacDonald et al. 2000; Kaufmann, Johnston et al. 2005). Studies on the expression of neurotransmitter receptors such as NMDA, AMPA, kainite, metabotropic glutamate receptors and GABA receptors show age related abnormalities in receptor densities in the frontal cortex and basal ganglia (Blue, Naidu et al. 1999; Blue, Naidu et al. 1999); Nevertheless, remains open question as to whether these morphological abnormalities are the cause or consequence of the Rett syndrome phenotype.

In Rett syndrome the balance between excitation and inhibition, that exist in healthy brains, is shifted (Dani, Chang et al. 2005; Moretti, Levenson et al. 2006). Many studies suggest that this synaptic imbalance may cause the Mecp2 observed abnormalities (Dani, Chang et al. 2005; Moretti, Levenson et al. 2006), but it is still unknown which transmitter and receptors are predominantly involved.

\subsubsection{Distribution of $\mathrm{GABA}_{B}$ receptor variants during brain development}

All three $\mathrm{GABA}_{\mathrm{B}}$ receptor proteins, namely $\mathrm{R} 1 \mathrm{a}, \mathrm{R} 1 \mathrm{~b}$ and $\mathrm{R} 2$, display a broad distribution, being present in all brain areas. However, the presence of each splice variant differs among brain regions, age, and cellular distribution.

In situ hybridization and immunohistochemical studies have shown an early and strong $\mathrm{GABA}_{\mathrm{B} 1}$ receptor expression in discrete brain regions during embryonic 
development (Kim, Li et al. 2003; Lopez-Bendito, Lujan et al. 2003; Panzanelli, Lopez-Bendito et al. 2004).

$\mathrm{GABA}_{\mathrm{B} 1}$ receptor mRNA is intensely expressed by $\mathrm{E} 12$ and is detected in hippocampus, cerebral cortex, intermediate and posterior neuroepithelium, and the pontine neuroepithelium (Lopez-Bendito, Shigemoto et al. 2002; Kim, Li et al. 2003). The most studied $\mathrm{GABA}_{\mathrm{B} 1}$ splice variants, $\mathrm{GABA}_{\mathrm{B} 1 \mathrm{a}}$ and $\mathrm{GABA}_{\mathrm{B} 1 \mathrm{~b}}$ are differentially regulated during postnatal maturation (Malitschek, Ruegg et al. 1998; Fritschy, Meskenaite et al. 1999; Liang, Hatanaka et al. 2000).

$\mathrm{GABA}_{\mathrm{B}} \mathrm{R} 1 \mathrm{a}$ is dominant in neonatal brain and increases within the first postnatal days (P0-P5) and then decreases to adult levels, whereas GABA $_{B} \mathrm{R} 1 \mathrm{~b}$ levels rise during the second and third postnatal weeks, i.e. during the peak of synaptogenesis, and is predominant in adulthood (Malitschek, Ruegg et al. 1998; Fritschy, Meskenaite et al. 1999; Calver, Medhurst et al. 2000; Martin, Russek et al. 2001).

In contrast to the immature brain, in the adult rat brain the $\mathrm{GABA}_{\mathrm{B} 1 \mathrm{~b}}$ levels are higher than $\mathrm{GABA}_{\mathrm{B} 1 \mathrm{a}}$ levels in most structures. Exceptions are the olfactory bulb and the striatum where higher levels of $\mathrm{GABA}_{\mathrm{B} 1 \mathrm{a}}$ than $\mathrm{GABA}_{\mathrm{B} 1 \mathrm{~b}}$ protein are detected (Bettler, Kaupmann et al. 2004).

Also sex dependant differences have been shown in combination with developmental changes of $G_{A B A} R 1$ variants. Specifically, in rat hypothalamus $G_{B} A_{B} R 1$ a was much higher expressed in females at birth whereas in males the higher expression of $\mathrm{GABA}_{\mathrm{B}} \mathrm{R} 1 \mathrm{a}$ starts after 38 days. $\mathrm{GABA}_{\mathrm{B}} \mathrm{R} 1 \mathrm{~b}$ showed no sex differences along development (Bianchi, Lux-Lantos et al. 2005).

Another developmental mediated difference is the alteration of the $\mathrm{GABA}_{\mathrm{B}}$ receptor binding affinity to L-baclofen. Although the binding affinity of the $\mathrm{GABA}_{\mathrm{B}}$ receptor to the agonist is the same between GABA $\mathrm{B}_{1 \mathrm{a}}$ and $\mathrm{GABA}_{\mathrm{B} 1 \mathrm{~b}}$ (Kaupmann, Huggel et al. 1997) in early postnatal development the affinity at R1a and R1b is 10-fold lower than in adult brain and gradually increases with aging (Malitschek, Ruegg et al. 1998). 


\subsection{Aim of this thesis}

When starting this study it was well documented that in the Central Nervous System there is a developmental switching in the function of the GABAergic system from early excitation to late mature inhibition. However, little is known about what controls this developmental shift in $\mathrm{GABA}_{\mathrm{A}}$ and $\mathrm{GABA}_{\mathrm{B}}$ receptors.

The aim of the study was to determine which factors are associated with the GABAergic functional differentiation during postnatal development in mouse brainstem. The following main questions were set:

- In order to specify what kind of modifications could influence the $\mathrm{GABA}_{\mathrm{B}}$ receptor function in brainstem during brain maturation, we were interested in understanding the following issues:

- Is there any developmental change in the expression of the $\mathrm{GABA}_{\mathrm{B}} \mathrm{R} 2$ subunit?

- How does the G protein subtyp expression differ in animals according to their developmental stage?

- How does the two factors mentioned above influence the interaction between $G$ proteins and $\mathrm{GABA}_{\mathrm{B}}$ receptors in adult and newborn mice?

- By which mechanism(s) does the age-related irregulation between excitation and inhibition in Mecp2 knockout mice (Rett syndrome) is associated with the $\mathrm{GABA}_{\mathrm{A}}$ receptors? 


\section{MATERIALS AND METHODS}

\subsection{Materials}

\subsubsection{Equipment}

\begin{tabular}{|c|c|}
\hline Equipment & Manufacturer \\
\hline Electroporator & Bio-Rad, Hercules, California, USA \\
\hline Electrophoresis chambers for DNA & Biometra, Göttingen, Germany \\
\hline Elektrophoresis Power supply & $\begin{array}{l}\text { EPS601, Amersham Biosciences, Freiburg, } \\
\text { Germany }\end{array}$ \\
\hline Gel dryer & $\begin{array}{l}\text { Model 583, Bio-Rad Laboratories GmbH, } \\
\text { München, Germany }\end{array}$ \\
\hline Incubators for cell culture & $\begin{array}{l}\text { Forma scientific } 3250 \text {, Water Jacketed Incubator, } \\
\text { Marietta, Ohio, USA }\end{array}$ \\
\hline Light microscopes & Carl Zeiss, Jena, Germany \\
\hline Magnetic stirrer with heating block & IKA RCT basic, North Carolina, USA \\
\hline Minishaker & MS1, IKA, North Carolina, USA \\
\hline PCR-Cycler & Biometra, Göttingen, Germany \\
\hline Plate reader & $\begin{array}{l}\text { GENios Pro, Tecan Deutschland GmbH, } \\
\text { Crailsheim, Germany }\end{array}$ \\
\hline Spectrophotometer & $\begin{array}{l}\text { GeneQuant pro, Amersham Biosciences, Freiburg, } \\
\text { Germany }\end{array}$ \\
\hline Speed Vac Concentrator & Beta, Christ, Osterode am Harz, Germany \\
\hline Thermo-shaker & T5-100, Kisker, Steinfurt, Germany \\
\hline
\end{tabular}

\subsubsection{Chemicals}

\begin{tabular}{ll}
\hline Name & Manufacturer \\
\hline AA30 / Rotiphorese gel 30 & Roth, Karlsruhe, Germany \\
Agarose & $\begin{array}{l}\text { Merck, Darmstadt, Germany } \\
\text { Invitrogen, Groningen, The Netherlands }\end{array}$ \\
Aprotinin A 1153 & Sigma, Taufkirchen, Germany \\
Aprotinin Ct. Nr.A 1153 & Sigma, Taufkirchen, Germany \\
BSA & Amersham Pharmacia Biotech, Little Chalfont, UK
\end{tabular}


Chloroform

Coomassie Brilliant Blue

DEPC-Treated water

(RS) Baclofen

Dimethylsulfate (DMSF)

EGTA

EDTA

Ethanol

D (+) Glucose

DMSO

Glycin

Guanosine 5 '-diphosphate sodium salt

Guanosine 5'-triphosphate sodium salt

HEPES

Jodacetatamide

Klenow enzyme

LB agar

Leupeptin L 9783

Imidazol

NP-40

Nuclease-free water

Oligo(dT) 15

Phenol/Cloroform/Isoamylalcohol

Phenylmethanesulfonyl fluoride

(PMSF)

Ponceau $\mathrm{S}$

Protein A immobilized on

Sepharose CL-4B

Ribonuclease inhibitor (RiboLock)

Sodium Dodecyl Sulphate (SDS)

ultra pure

Sodium Chloride
Merck, Darmstadt, Germany

Merck, Darmstadt, Germany

Ambion, Huntingdon, Cambridgeshire, UK

Tocris, Bristol, UK

Sigma, Taufkirchen, Germany

Sigma, Taufkirchen, Germany

Roth GmbH \& Co., Karlsruhe, Germany

Calbiochem, San Diego, California, USA

Roth, Karlsruhe, Germany

Sigma, Taufkirchen, Germany

Sigma, Taufkirchen, Germany

Sigma, Taufkirchen, Germany

Sigma, Taufkirchen, Germany

Roth, Karlsruhe, Germany

Sigma, Taufkirchen, Germany

Roche, Mannheim, Germany

Invitrogen, Groningen, The Netherlands

Sigma, Taufkirchen, Germany

Roth, Karlsruhe, Germany

Calbiochem, San Diego, California, USA

Ambion, Huntingdon, Cambridgeshire, UK

MWG-Biotech AG, Ebersberg, Germany

Amersham Pharmacia Biotech, Little Chalfont, UK

Calbiochem, San Diego, California, USA

Sigma, Taufkirchen, Germany

Sigma, Taufkirchen, Germany

MBI Fermentas, St. Leon-Rot, Germany

Roth, Karlsruhe, Germany

Roth, Karlsruhe, Germany 
T4 DNA ligase, buffer

TEMED
Roche, Mannheim, Germany

Roth, Karlsruhe, Germany

Tris (hydroxymethyl) aminomethane Roth, Karlsruhe, Germany (TRIS)

$\begin{array}{ll}\text { TritonX100 } & \text { Roth, Karlsruhe, Germany } \\ \text { Tween } 20 & \text { Roth, Karlsruhe, Germany } \\ \beta \text {-Mercaptoethanol } & \text { Sigma, Taufkirchen, Germany }\end{array}$

\subsubsection{Additional materials}

KodakX-O mat AR Film

35S-GTP $\gamma$ S Cat. Nr. KS 302/0925

Membrane hybond ECL

Whatman GB58 blotting-Paper B002Heinemann Labotechnik GmbH, Hainichen, Germany
Kodak, Rochester, USA

Hartmann Analytic GmbH, Braunschweig, Germany

Amersham Biosciences, Freiburg, Germany

\subsubsection{Software}

Image processing

Microscopy

Sequence analysis/ Virtual cloning

Text processing

Graphs and tables

Western analysis
Adobe Photoshop CS, Adobe

Leica confocal software, Leica

DNAstar, Lasergene Navigator

Microsoft Word, Microsoft Corp.

Excel, Microsoft Corp.

Adobe Illustrator CS, Adobe

Prism 4.0, GraphPad Software, Inc.

Instat 3 for Mac, GraphPad Software, Inc

Chemi-Smart 5000, Vilber Lourmat

Bio-1D, Vilber Lourmat

Gel-ProAnalyzer 3.1, Media Cybernetics

\subsubsection{Web pages}

BLAST www.ncbi.nln.nih.gov./BLAST

PubMed www.ncbi.nln.nih.gov 
Protein calculation www.mrc-Imb.cam.ac.uk/rpg/proteincalculator.html.

ClustalW www2.ebi.ac.uk/clustalw

\subsubsection{Molecular markers}

\subsubsection{DNA molecular weight standard}

100 bp DNA Ladder Invitrogen, Groningen, The Netherlands

DNA Ladder N3014S New England Biolabs, Frankfurt am Main, Germany

$1 \mathrm{~Kb}$ DNA Ladder Invitrogen, Groningen, The Netherlands

\subsubsection{Protein molecular weight standard}

The approximate molecular weight of proteins in SDS-polyacrylamide gels was determined according to (Cat. No.: 10748-010) BenchMark Pre-Stained Protein molecular weight marker $(6.0-181.8 \mathrm{kDa})$ from Invitrogen.

Protein molecular weight calculations according to the amino acid sequence were performed using the program at www.mrc-Imb.cam.ac.uk/rpg/proteincalculator.html.

Additional molecular weight markers:

SDS-PAGE standards, Low range (34.3-103 kDa) BioRad, California, USA

SDS-PAGE standards, High range (48-204 kDa) BioRad, California, USA

SDS-PAGE standards, Broad range (7.1-209 kDa) BioRad, California, USA

\subsubsection{Kits}

Gel extraction kit-QIAEX ${ }^{\circledR}$ II $\quad$ Qiagen, Hilden, Germany

Omniscript RT kit (Cat Nr. 205111) Qiagen, Hilden, Germany

ECLTM western blotting detection Amersham Biosciences, Freiburg, Germany reagents

Membrane blocking agent

Amersham Biosciences, Freiburg, Germany

GTP-Eu

PerkinElmer life sciences, Boston, USA 
cAMP Biotrak enzymeimmunoassay (EIA) system

Expand long template PCR system

High fidelity PCR

MBS mammalian transfection kit

Total protein kit
Amersham Biosciences, Freiburg, Germany

Roche, Manheim, Germany

Roche, Manheim, Germany

Stratagene, La Jolla, USA

Sigma, Taufkirchen, Germany

\subsubsection{Antibodies}

\subsubsection{Primary antibodies}

\begin{tabular}{|c|c|c|c|}
\hline Antibodies & Raised in & Clonality & Company \\
\hline $\begin{array}{l}\text { Anti-metabotropic Glutamate } \\
\text { receptor } 2 / 3\end{array}$ & Rabbit & Polyclonal & Chemicon \\
\hline Anti-Glutamate Receptor 1 & Rabbit & Polyclonal & Chemicon \\
\hline $\begin{array}{l}\text { Anti-NMDA NR1 Subunit, } \\
\text { splice Variant C1 }\end{array}$ & Mouse & Polyclonal & Biomol \\
\hline Anti-phospho-NR1 (Ser896) & Rabbit & Polyclonal & Biomol \\
\hline Anti-phospho-NR1 (Ser897) & Rabbit & Polyclonal & Biomol \\
\hline Anti-NMDA Receptor 2A\&B & Rabbit & Polyclonal & Chemicon \\
\hline Anti-NMDA Receptor 3B, & Rabbit & Polyclonal & Biomol \\
\hline Anti-NMDA Receptor 1, (54.1) & )Mouse & Polyclonal & upstate \\
\hline Anti-NMDA Receptor1, (54.2) & Mouse & Polyclonal & SynapticSystems, Göttingen \\
\hline Anti-NMDA Receptor2A & Rabbit & Polyclonal & Chemicon \\
\hline $\begin{array}{l}\text { anti-synaptophysin (Clone } \\
\text { Sy38) }\end{array}$ & Mouse & Monoclonal & Dako, Denmark \\
\hline Actin & Rabbit & Monoclonal & Sigma \\
\hline Hsp70 & Goat & Polyclonal & Santa cruz biotechnology, inc. \\
\hline $\begin{array}{l}\text { Glycine Receptor } \\
\text { (all Subunits) }\end{array}$ & Mouse & Polyclonal & Alexis \\
\hline $\mathrm{GABA}_{\mathrm{A}}$ Receptor alpha 1 & Goat & Polyclonal & Santa cruz biotechnology, inc. \\
\hline GABA $_{A}$ Receptor alpha 2 & Goat & Polyclonal & Santa cruz biotechnology, inc. \\
\hline $\mathrm{GABA}_{\mathrm{A}}$ Receptor alpha 3 & Goat & Polyclonal & Santa cruz biotechnology, inc. \\
\hline $\mathrm{GABA}_{\mathrm{A}}$ Receptor alpha 5 & Goat & Polyclonal & Santa cruz biotechnology, inc. \\
\hline
\end{tabular}




\begin{tabular}{|c|c|c|c|}
\hline $\mathrm{GABA}_{\mathrm{A}}$ Receptor beta 3 & Goat & Polyclonal & Santa cruz biotechnology, inc. \\
\hline GABA $_{\mathrm{A}}$ Receptor alpha 2 & Rabbit & Polyclonal & Abcam \\
\hline $\mathrm{GABA}_{\mathrm{A}}$ Receptor alpha 3 & Rabbit & Polyclonal & Abcam \\
\hline $\mathrm{G} \alpha_{\mathrm{s}}(\mathrm{K}-20) \mathrm{Sc}-823$ & Rabbit & Polyclonal & Santa cruz biotechnology, inc. \\
\hline $\mathrm{G} \alpha_{\mathrm{q} / 11}(\mathrm{C}-19) \mathrm{Sc}-392$ & Rabbit & Polyclonal & Santa cruz biotechnology, inc. \\
\hline $\mathrm{G \alpha}_{\mathrm{i} / \mathrm{o}}(\mathrm{K}-20) \mathrm{Sc}-387$ & Rabbit & Polyclonal & Santa cruz biotechnology, inc. \\
\hline $\mathrm{G \alpha}_{\mathrm{i}-3}(\mathrm{C}-10) \mathrm{Sc}-262$ & Rabbit & Polyclonal & Santa cruz biotechnology, inc. \\
\hline $\mathrm{G}_{13}(\mathrm{~A}-20) \mathrm{Sc}-410$ & Rabbit & Polyclonal & Santa cruz biotechnology, inc. \\
\hline G $\beta(M-14)$ Sc-261 & Rabbit & Polyclonal & Santa cruz biotechnology, inc. \\
\hline $\mathrm{GABA}_{\mathrm{B}} \mathrm{R} 1(\mathrm{H}-300)$ & Rabbit & Polyclonal & Santa cruz biotechnology, inc. \\
\hline Anti-GABA ${ }_{B} R 1$ Receptor & Guinea Pig & Polyclonal & Chemicon \\
\hline Anti-GABA ${ }_{B} R 2$ Receptor & Guinea Pig & Polyclonal & Chemicon \\
\hline
\end{tabular}

\subsubsection{Secondary antibodies}

\begin{tabular}{llll}
\hline $\begin{array}{l}\text { Secondary antibodies } \\
\text { specificity }\end{array}$ & Host & Conjugates & Company \\
\hline ECL Rabbit IgG, & Donkey & HRP & Amersham Bioscience \\
ECL Mouse IgG, & Sheep & HRP & Amersham Bioscience \\
Anti-Goat IgG $(\mathrm{H}+\mathrm{L})$ & Donkey & HRP & Dianova \\
Anti-Mouse IgG & Goat & HRP & Chemicon \\
Guinea pig & Goat & HRP & Dianova \\
Guinea Pig IgG $(\mathrm{H}+\mathrm{L})$ & Donkey & Cy3 (indocarbocyanin) & Dianova \\
Rabbit Cy5 IgG $(\mathrm{H}+\mathrm{L})$ & Goat & Cy5 (indodicarbocyanin) & Dianova \\
\hline
\end{tabular}

\subsubsection{Peptide}

$\mathrm{GABA}_{\mathrm{A}}$ Receptor alpha 2

$\mathrm{GABA}_{\mathrm{A}}$ Receptor alpha 3

$\mathrm{GABA}_{\mathrm{A}}$ Receptor alpha 5

$\mathrm{GABA}_{\mathrm{A}}$ Receptor alpha 6 
$\mathrm{GABA}_{\mathrm{A}}$ Receptor beta 3

$\mathrm{G} \alpha_{\mathrm{s}}$

\subsubsection{Animals}

Adult (between 3-4 weeks) and young (between postnatal day 0 and 3; P0-P3) NMRI mice, were used in the experiments. The mice were purchased from the animal center of the University of Gottingen. Animal experiments were carried out in accordance with the guidelines of the Ethics Committee of the University of Göttingen.

New born mice (P0-P3) were rapidly decapitated at the C3-C4 level; The Adult animals were anesthetized with ether and then decapitated. The skulls were opened and the brains were rapidly removed and placed in ice cold artificial cerebrospinal fluid (ACSF). The solution (ACSF) was gassed continuously and saturated with 95 $\% \mathrm{O}_{2}$ and $5 \% \mathrm{CO}_{2}$. The further procedure depends on the method which is going to follow (see section 2.2.1.1; 2.2.2.1; 2.2.5, 2.2.6.1).

\subsubsection{Cell culture}

- Eukaryotic cell lines: HEK293 Flp-In (Invitrogen, Karlsruhe, Germany)

- cDNA plasmids: pcIneo-GABA $\mathrm{B} 1 \mathrm{a}$ and R2 cDNA of rat, kindly provided by Dr. Klemens Kaupmann, Novartis Pharma AG.

- Bacterial Strains: Escherichia coli XL1-Blue MRF' (Stratagene, La Jolla, California, USA) 


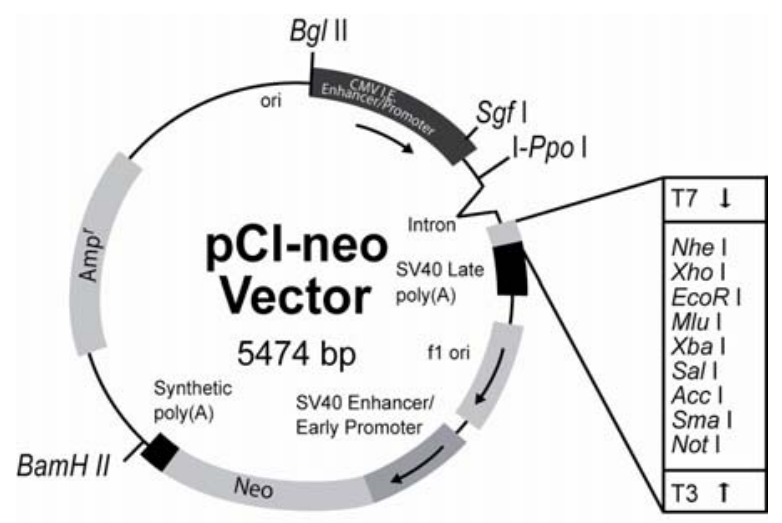

Figure 2.1. pCI-neo vector circle map $(\mathrm{Neo}=$ neomycinphoshotransferase). Amp ${ }^{r}$, gene conferring the ampicillin resistance in E.coli; fl ori, origin of replication derived from filamentous phage; ori, origin of replication. Arrows indicate the direction of transcription.
- Antibiotics: Ampicillin

Hygromycin B

Zeocin

Penicillin-Streptomycin
Amersham Pharmacia Biotech, Little Chalfont, UK

Invitrogen, Karlsruhe, Germany

Invitrogen, Karlsruhe, Germany

Invitrogen, Karlsruhe, Germany

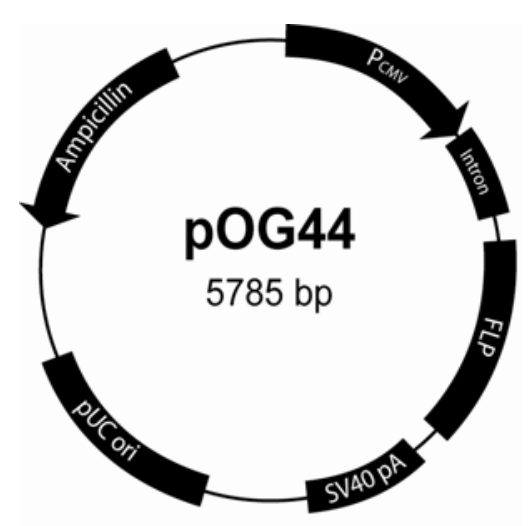

Figure 2.2. pOG44 vector circle map. Ampicillin, Ampicillin resistance gene; pCMV, CMV promoter; FLP, Flp recombinase, synthetic intron, SV40 late polyadenylation signal, pUC origin. Arrows indicate the direction of transcription.

- Vectors:

pcDNA5/FRT
pCI-neo
pOG44

pBudCE4.1
Invitrogen, Karlsruhe, Germany

Invitrogen, Karlsruhe, Germany

Invitrogen, Karlsruhe, Germany

Invitrogen, Karlsruhe, Germany 


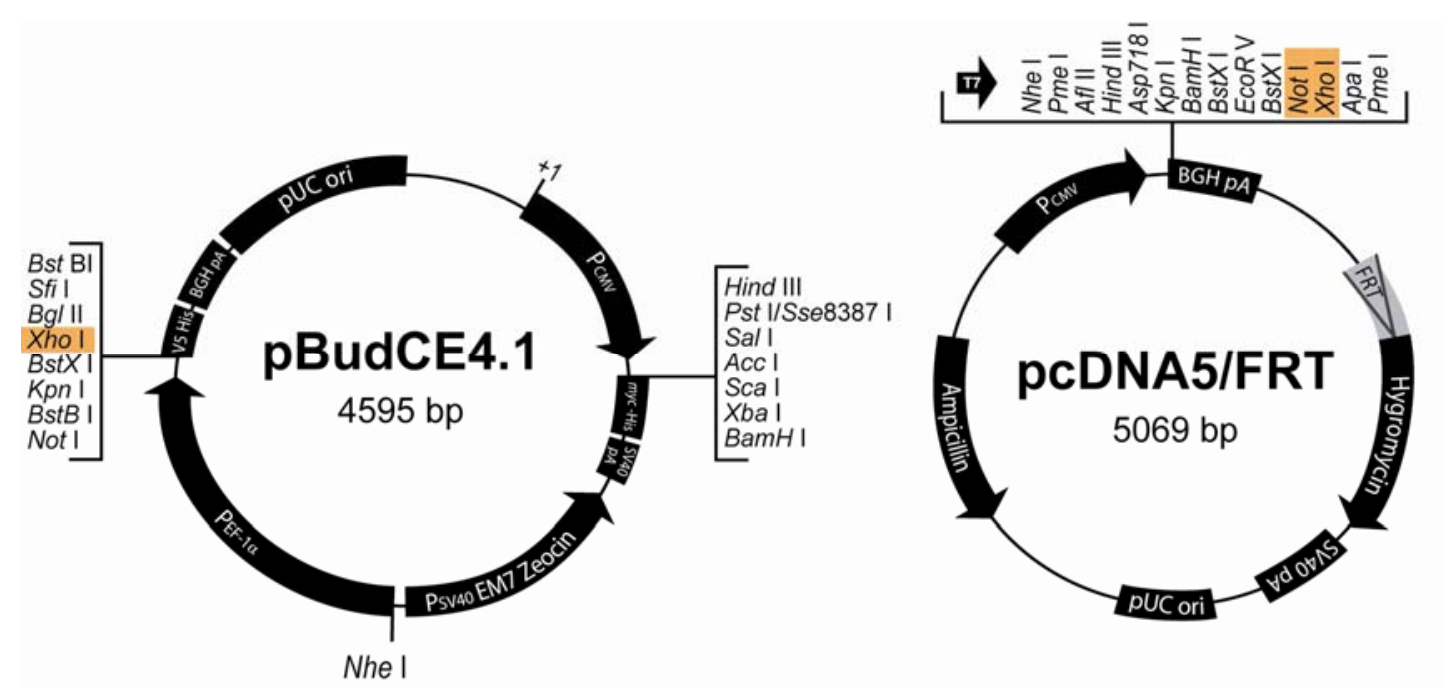

Figure 2.3. Structure of the pBudCE4.1 and pcDNA5/FRT vectors. The

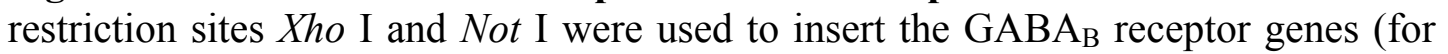
more details see figure 2.5). Arrows indicate functional direction of genes. Ampicillin, Ampicillin resistance gene; Hygromycin, Hygromycin resistance gene (no ATG); Zeocin, Zeocin resistance gene; $\mathrm{P}_{\mathrm{CMV}}$, CMV promoter, myc epitope, 6xHis tag; SV40 polyadenylation sequence, EM7 promoter; $\mathrm{P}_{\mathrm{SV} 40}, \mathrm{SV} 40$ early promoter; pUC origin; V5 epitop; BGH polyadenylation sequence.

\subsubsection{Reagents for cell culture}

$\mathrm{dH} 2 \mathrm{O}$

Dulbecco's Modified Eagle Medium (DMEM)

D-PBS

Trypsin/EDTA
Invitrogen, Groningen, The Netherlands

Invitrogen, Groningen, The Netherlands

Invitrogen, Groningen, The Netherlands

Invitrogen, Groningen, The Netherlands 


\subsection{Methods}

\subsubsection{Molecular biology methods}

\subsubsection{Isolation of total RNA from mice brainstem}

The typical eukaryotic cell contains $\sim 10-5 \mu \mathrm{g}$ of total RNA.

- $80-85 \%$ is rRNA (ribosomal) (mostly $28 \mathrm{~S}, 18 \mathrm{~S}$ and $5 \mathrm{~S}$ )

- $15-20 \%$ is low MW species tRNA(transfer), snRNA (small nuclear) plus others and

- $1-5 \%$ is mRNA (messenger)

The major concern in handling RNA is the control of ribonuclease activity. For preventing RNase contamination it was essential to use RNase-free gloves, sterile Reagents, RNaseZap (Sigma), pre-packed RNase-free pipette tips and autoclaved glass- and plastic ware.

Total RNA was isolated from NMRI mice brainstem using, TRIzol reagent according to manufacturer's protocol (Invitrogen life technologies) (Chomczynski, P., and Sacchi, N., 1987). Briefly, after decapitation (see section 2.1.9), the brainstem were dissected, weighed, and homogenized in TRIzol reagent at a ratio of $1 \mathrm{ml} / 100 \mathrm{mg}$ brainstem wet weight.

TRIzol is a monophase solution of phenol and guanidine isothiocyanate which maintains the integrity of the RNA, while disrupting cells and dissolving cell components. An additional isolation step was required because of the high content of proteins and lipids in the brain compared to other tissues. For this reason the samples were centrifuged at $12.000 \mathrm{x} g$ for $10 \mathrm{~min}$. at $4{ }^{\circ} \mathrm{C}$. The resulting pellet contains extracellular membranes, polysaccharides, and high molecular weight DNA, while the supernatant contains the RNA.

The supernatant was transferred to a new tube and after 5 min incubation at RT, 200 $\mu 1$ chloroform was added, mixed and incubated for 3 min at RT. After centrifugation at $12.000 \mathrm{x} \mathrm{g}$ for $15 \mathrm{~min}$. at $4{ }^{\circ} \mathrm{C}$, three phases were separated: a low phenolchlorophorm phase, an interphase, and a colorless upper RNA containing aqueous phase. For the RNA precipitation the aqueous phase was transferred to a new tube and mixed with $500 \mu$ isopropylalcohol. RNA was precipitated for $10 \mathrm{~min}$ at RT and pelleted by centrifugation at $12.000 \mathrm{x} g$ for $10 \mathrm{~min}$ at $4{ }^{\circ} \mathrm{C}$. 
The RNA pellet was washed twice with $75 \%$ ethanol solution (diluted with DEPCtreated water), air dried and, dissolved in $50 \mu \mathrm{l}$ RNase-free water. After $10 \mathrm{~min}$ incubation at $37^{\circ} \mathrm{C}$, followed:

- Quantification of the RNA concentration (OD $260 \mathrm{~nm}$ ).

- Purity determination of the RNA (OD 260/280 nm).

- Examination of the RNA integrity (18S/28S).

I Quantification of RNA concentration (OD $260 \mathrm{~nm}$ )

Concentration of the total cell RNA was determined by measuring the OD at $260 \mathrm{~nm}$. An $\mathrm{OD}_{260}$ of 1 corresponds to approximately $40 \mu \mathrm{g}$ of RNA per ml.

II Purity determination of the RNA (OD 260/280 nm)

The ratio $\mathrm{A}_{260} / \mathrm{A}_{280}$ is an indication of the purity of the RNA. The ratio (for pure RNA) should be in the range of 1.8-2.0. But even if the ratio is less than 1.8, the RNA quality may be acceptable and this can be confirmed by gel electrophoresis.

III Examination of the RNA integrity (18S/28S)

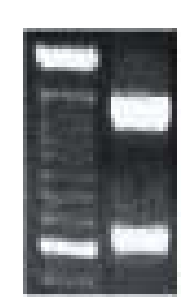

Figure 2.4. Intact RNA. Five $\mu \mathrm{g}$ of total cell RNA were run on a $1.5 \%$ agarose gel. The $18 \mathrm{~S}$ and $28 \mathrm{~S}$ ribosomal RNA bands are clearly visible.
The quality of the RNA was checked by loading $5 \mu \mathrm{g}$ RNA on $1.5 \%$ agarose gel in TBE with $2,5 \mu \mathrm{g} / \mathrm{ml}$ ethidium bromide. The gel was visualised under UV light to evaluate RNA yield.

The 28S rRNA band was approximately twice as intense as the 18S rRNA band. This 2:1 ratio $(28 \mathrm{~S}: 18 \mathrm{~S})$ is a good indication that the RNA is intact. Partially defragged RNA would have a smeared appearance, or would not exhibit a 2:1 ratio.

\subsubsection{Reverse transcription-Polymerase Chain Reaction (RT-PCR)}

The OmniScript kit (Qiagen, Hilden) was used for the reverse transcription of mRNA in a complementary DNA (cDNA). 
Reaction mixture for RT-PCR $(20 \mu 1)$ :

\begin{tabular}{lll}
\hline Component & Volume/reaction & Final concentration \\
\hline Master mix & & \\
10x Buffer RT & $2 \mu \mathrm{x}$ & $1 \mathrm{x}$ \\
dNTP Mix (5 mM each dNTP) & $2 \mu \mathrm{l}$ & $0.5 \mathrm{mM}$ each dNTP \\
Oligo-dT primer $(100 \mathrm{pmol} / \mu \mathrm{l})$ & $0.2 \mu \mathrm{l}$ & $1 \mathrm{mM}$ \\
RNase inhibitor $(40$ units/ $\mu \mathrm{l})$ & $0.25 \mu \mathrm{l}$ & 10 units (per $20 \mu \mathrm{l}$ reaction) \\
Omniscript Reverse Transcriptase & $1 \mu \mathrm{l}$ & 4 units (per $20 \mu \mathrm{l}$ reaction) \\
RNase-free water & Variable & \\
Template RNA (added at the end) & Variable & $10 \mu \mathrm{g}$ (per $20 \mu \mathrm{l}$ reaction) \\
\hline
\end{tabular}

The isolated RNA from 2.2.1.1 was used as a template and the reaction was performed according to the protocol provided by Qiagen.

$10 \mu \mathrm{g}$ of total RNA was used for the PCR reaction with 100 pmol/ $\mu 1$ Oligo (dT) 15Primer (MWG-Biotech AG) in a final volume of $20 \mu 1$.

The mix was prepared (on ice) as listed in the table above. The reaction mixture was incubated for $60 \mathrm{~min}$. at $37^{\circ} \mathrm{C}$. The isolated cDNA was used for following PCRs

\subsubsection{Agarose gel electrophoresis}

Agarose gel electrophoresis was performed for separation, identification and purification of DNA. The concentration of agarose was used for separation of the fragments with different lengths.

DNA fragments were separated according to their molecular weight through electrophoresis in horizontal 0.8-1.5\% agarose gels.

\begin{tabular}{ll}
\hline Agarose [\%] & Fragment length [kb] \\
\hline 0.5 & $1-30$ \\
0.7 & $0.8-12$ \\
1.0 & $0.5-10$ \\
1.2 & $0.4-3$
\end{tabular}


$1.5 \quad 0.2-3$

$2.0 \quad 0.01-1$

Agarose solutions were prepared by dissolving the desired amount of agarose in TAE buffer, in a microwave oven. Ethidium bromide was added to a final concentration of $1 \mu \mathrm{g} / \mu 1$. The samples were loaded onto gels with 0.2 volume loading Buffer. Gels were run horizontally at $60-80 \mathrm{mV}$ in $1 \mathrm{xTAE}$ buffer for minimum of $30 \mathrm{~min}$.

The DNA bands were made visible and photographed under UV light. Size of DNA fragments were determined by comparison with DNA ladders.

$\begin{array}{lll}\text { Stock solution 50xTAE (for 1 1): } & 242 \mathrm{~g} & \text { Tris } \\ & 57.1 \mathrm{ml} & \text { Acetic acid } \\ 100 \mathrm{ml} & 0.5 \mathrm{M} \text { EDTA pH } 8.0 \\ & & \mathrm{H}_{2} \mathrm{O}\end{array}$

Loading buffer:

$\begin{array}{ll}10 \mathrm{mM} & \text { EDTA pH } 8.0 \\ 100 \mathrm{mM} & \text { Tris pH } 8.0 \\ 57 \% & \text { glycerol } \\ & \text { bromphenolblue }\end{array}$

\subsubsection{Extraction of the DNA fragments from agarose gels}

DNA fragments were separated according to their size by Agarose gel electrophoresis. DNA band was cut from the agarose gel with a clean scalpel. DNA Purification was carried out according to the manual of Qiagen Gel Extraction Kit (Qiagen, Germany).

\subsubsection{Biochemical methods}

\subsubsection{Preparation of protein extracts}

Aliquots (see section 2.1.9) of different mice brain areas (cortex, hippocampus and brainstem) were weighted, immediately frozen in liquid nitrogen, and stored at $-80{ }^{\circ} \mathrm{C}$ until homogenization. 
The brain samples were homogenized with a glass teflon homogenisator (homgen ${ }^{\text {plus }}$, Schütt) at setting $2000 \mathrm{rpm}$ and 10 strokes, in a buffer $(40 \mathrm{w} / \mathrm{v})$ containing $1 \mathrm{mM}$ EDTA, $20 \mathrm{mM}$ HEPES pH 7.4, $0.1 \mathrm{mM}$ PMSF, $2 \mu \mathrm{g} / \mathrm{ml}$ aprotinin and $2 \mu \mathrm{g} / \mathrm{ml}$ leupeptin. The homogenates were placed in ice-cold lysis buffer (1:1) (RIPA with $1 \%$ NP 40) and incubated at $4{ }^{\circ} \mathrm{C}$ for $2 \mathrm{~h}$. The supernatant was cleared by centrifugation at $14.000 \mathrm{rmp}$ at $4{ }^{\circ} \mathrm{C}$ for $30 \mathrm{~min}$. The protein measurement was determined by Lowry assay as described in section 2.2.2.2. The samples were combined with $3 x$ loading buffer (62,5 mM Tris-HCl, $20 \%$ glycerol, $6 \%$ SDS, 0,01\% bromphenolblue, $10 \%$ $\beta$-mercaptoethanol) and boiled at $100{ }^{\circ} \mathrm{C}$ for $5 \mathrm{~min}$. Boiling denatures proteins, unfolding them completely. SDS then surrounds the protein with a negative charge and the beta-mercaptoethanol prevents the reformation of disulfide bonds.

\subsubsection{Determination of protein concentration}

The total protein concentration was assessed by the Lowry technique, as modified by Peterson using the total protein kit from Sigma and with bovine serum albumin (BSA) (Sigma) as standard.

Aliquots of samples $(5 \mu \mathrm{l})$ were diluted in water to a final volume of $50 \mu \mathrm{l}$. Each protein concentration determination was carried out in triplicate.

The standard curve was prepared as follows. Bovine serum albumin (BSA) powder was dissolved in distilled water and diluted to a concentration of $400 \mu \mathrm{g} / \mathrm{ml}$. A series of dilutions $(0,50,100,200,300,400 \mu \mathrm{g} / \mathrm{ml})$ were prepared in triplicates with a final volume of $50 \mu \mathrm{l}$. Standards and samples were transferred to a microplate (96 well plate, Newton Inc.), $50 \mu 1$ of Lowry reagent was added to each well and mixed with repeated pipeting. The mixture was then allowed to incubate at RT for 20 min. prior to the addition of $25 \mu 1$ per well of Folin \& Ciocalteu's Phenol reagent. Samples were mixed immediately with repeated pipeting with each addition. Absorbance was measured at a wavelength between 500 and $800 \mathrm{~nm}$. All absorbance determinations were performed using a Microplate Reader (BioRad). Analysis and statistics of the curve were performed using Sigma Plot and Excel software. 


\subsubsection{Sodium Dodecyl Sulfate-Polyacrylamide gel Electrophoresis (SDS-PAGE)}

SDS-PAGE is a qualifying and quantifying method for proteins. With this Method proteins can be separated on the basis of mass by electrophoresis in a polyacrylamide gel according to Laemmli et al. (1970).

SDS is an anionic detergent which binds to the proteins and confers a negative charge to the polypeptides in proportion to there length.

The negative charges of SDS destroy most of the complex structure of proteins which migrate towards the anode in an electric field.

Finally the polyacrylamide gels with there porous structure separate the proteins according to there relative molecular weight.

\begin{tabular}{lll}
\hline Solution & Separation gel (10 \%) & Stacking gel (5 \%) \\
\hline AA30 & $2,5 \mathrm{ml}$ & $0,325 \mathrm{ml}$ \\
4xTris/HCL SDS 8.8 & $1,875 \mathrm{ml}$ & - \\
4xTris/HCL SDS 6.8 & - & $0,787 \mathrm{ml}$ \\
bidest. H2O & $3,125 \mathrm{ml}$ & $1,525 \mathrm{ml}$ \\
Themed & $7,5 \mu \mathrm{l}$ & $3,7 \mu 1$ \\
APS & $40 \mu \mathrm{l}$ & $20 \mu 1$ \\
\hline
\end{tabular}

Protein gel electrophoresis was performed using a minigel vertical apparatus under reducing conditions. The vertical gels were poured between two glass plates $(10,5 \times 10$ $\mathrm{cm}$ ) sealed with a silicone rubber band giving an internal thickness of $0.6 \mathrm{~mm}$ between the two plates. The gels were composed of a separation gel $(10 \%)$ that separates the proteins according to their size and a stacking gel (5\%) that insures the simultaneous entry of the proteins into the separating gel. After pouring the separation gel, the gel was overlaid with isopropanol to straighten the gel surface. When polymerisation was completed the isopropanol was removed, the stacking gel was poured above the separation gel and a ten wells comp of $0.6 \mathrm{~mm}$ was fixed. After polymerisation of the stacking gel, the comp and the silicone rubber were removed and the gel was assembled in the gel electrophoresis apparatus with the electrophoresis buffer. Air bubbles were removed and samples and ladder were loaded into the wells of the stacking gel using a Hamilton Syringe (Hamilton company). 


$\begin{array}{lll}\text { 4xTris/HCl SDS, pH } 8.8(500 \mathrm{ml}): & \begin{array}{l}91 \mathrm{gr} \\ 2 \mathrm{gr}\end{array} & \begin{array}{l}\text { Tris-HCl } \\ \text { SDS }\end{array} \\ \text { 4xTris/HCl SDS, pH } 6.8(500 \mathrm{ml}): & \begin{array}{l}30,25 \mathrm{gr} \\ 2 \mathrm{gr}\end{array} & \begin{array}{l}\text { Tris-HCl } \\ \text { SDS }\end{array} \\ & & \\ \text { 10x Electrophoresis buffer }(11): & 30,2 \mathrm{gr} & \text { Tris-HCl } \\ & 144 \mathrm{gr} & \text { glycine } \\ & 10 \mathrm{gr} & \text { SDS } \\ & \text { Add. H20 } & \end{array}$

Power supply was attached and the gel electrophoresis was carried out in SDS electrophoresis buffer at 80 Volt until the bromphenolblue dye front had passed stacking gel and afterwards at 150 Volt until the end of the electrophoresis. Electrophoresis was terminated, after the bromphenolblue dye front had passed through the majority of the separating gel. For size markers, BenchMark pre-stained protein molecular weight marker $(6.0-181.8 \mathrm{kDa})$ from Invitrogen, and the low range, high range and broad range prestained standards from BioRad were used.

\subsubsection{Coomassie blue staining of SDS gels}

After electrophoresis, stacking gel was removed and the separating gel was stained at RT for $30 \mathrm{~min}$ in a staining solution.

The coomassie solution was then removed and the gel was covered with destain solution under gentle agitation. The destaining solution was changed several times, removing it at each change by aspiration. The gel was completely destained until the protein bands appeared against a clear background. Afterwards the gel was left overnight covered with water. The next day the gel was dried placed onto a sheet of Whatman paper, covered with plastic wrap and dried for $1 \mathrm{~h}$ in a gel dryer (Model 583, BioRad) at $80^{\circ} \mathrm{C}$.

$\begin{array}{lll}\text { Coomassie stain }(300 \mathrm{ml}): & 30 \mathrm{ml} & \text { Acetic acid } \\ & 75 \mathrm{ml} & \text { isopropanol } \\ & 195 \mathrm{ml} & \mathrm{H}_{2} \mathrm{O}\end{array}$


0.2 gr Coomassie Brilliant Blue R250

$\begin{array}{lll}\text { Destaining solution (1 1): } & \begin{array}{ll}100 \mathrm{ml} & \text { Acetic acid } \\ 900 \mathrm{ml} & \mathrm{H}_{2} \mathrm{O}\end{array}\end{array}$

\subsubsection{Western blot analysis}

For the immunological detection of proteins, separated by SDS-PAGE, proteins were transferred onto nitrocellulose membranes (Hybond ECL, Amersham) using a semidry technique

A piece of nitrocellulose membrane and 6 pieces of Whatman papers with the same size as the gel were soaked with transfer buffer for $15 \mathrm{~min}$. The blot was assembled from the cathode to the anode as follow: 3 Whatman papers, gel, nitrocellulose membrane, and 3 Whatman papers. The transfer was performed under a current density of $1 \mathrm{~mA} / \mathrm{cm}^{2}$ for $2 \mathrm{~h}$. To verify transfer efficiency the nitrocellulose membranes were reversibly stained with Ponceau S solution.

10x Transfer Buffer (1 1) 30,2 gr Tris-HCl

144 gr Glyzin

$5 \mathrm{gr} \quad \mathrm{SDS}$

Add. $\quad \mathrm{H}_{2} \mathrm{O}$

Transfer Buffer $(100 \mathrm{ml}): \quad 10 \mathrm{ml} \quad$ 10x Transfer Buffer

$20 \mathrm{ml}$ Methanol

$70 \mathrm{ml} \quad \mathrm{H}_{2} \mathrm{O}$

\subsubsection{Staining membranes with Ponceau $S$}

For control and detection of proteins on a membrane after transfer, the membrane was incubated in Ponceau S solution for $2 \mathrm{~min}$ at RT. The colored membranes were rinsed with water and the position of proteins and weight standard was marked. For further use, the membranes were washed with PBS-Tween, until they became white again. 


$\begin{array}{lll}\text { Ponceau S solution (1 1): } & 2 \mathrm{gr} & \text { Ponceau S } \\ & 50 \mathrm{ml} & \text { Acetic acid } \\ & 950 \mathrm{ml} & \mathrm{H}_{2} \mathrm{O}\end{array}$

\subsubsection{Immunodetection of proteins in western blot using horseradisch- peroxidase-conjugated antibodies.}

After protein transfer the unspecific binding sites were blocked by incubation in $5 \%$ milk powder (blocking agent Amersham) in PBS/Tween for $2 \mathrm{~h}$ at RT. The membranes were then incubated with the primary antibody, diluted to the desired concentration in $5 \%$ milk-PBS/Tween solution overnight at $4{ }^{\circ} \mathrm{C}$ under gentle agitation. The primary antibody (monoclonal or polyclonal) recognises a specific epitop in the protein of interest. The membrane was then washed four times with PBS/Tween $(5,15,30$ and $30 \mathrm{~min})$ to remove the unbound primary antibody. The appropriate horseradish peroxidase (HRP)-conjugated secondary antibody was diluted in PBS/Tween, added to the membrane and incubated at RT for $30 \mathrm{~min}$, and washed as above. The choice of the secondary antibody depends on the species of animal in which the primary antibody was raised (host species) and it binds to the Fc region of the primary antibody.

The immunological detection of the proteins was performed using chemiluminescent detection reagents (ECL western blotting detection Reagent, Amersham Bioscience; AceGlow reagents, peqlab biotechnologie $\mathrm{GmbH}$ ) based on a luminol-HRPchemiluminescence reaction. The HRP reduces the hydrogen peroxide and the resulting oxygen oxidizes the luminol which emits light. The light was then detected either by photographic film or by a CCD camera which capture a digital image of the western blot.

Densiometric analysis of scanned images: blots were developed using the ECL western blotting detection reagent (Amersham Pharmacia Biotech) according to the manufacturer's instructions. Briefly the membrane was incubated for $1 \mathrm{~min}$ at RT with the ECL solutions 1 and 2 (1:1). The membrane was then covered with plastic film and placed in a developing cassette. The membranes were exposed to KodakX films (Kodak) for different time periods and films were developed using the Kodak developer and fixer solutions (GBX Fixer, Kodak; GBX developer, Kodak). The 
densiometric quantitation of the scanned images was performed with the Gel-Pro Analyzer Version 3.1 software (Media Cybernetics).

For the densiometric analysis of the digital images from a CCD camera: the detection was performed with the AceGlow Chemilumineszenzsubstrat (peqlab) in a mixture of solution A and B (1:1) by incubation for $1 \mathrm{~min}$. Quantitation of chemiluminescent signals was performed with the image acquisition system Chemi-Smart 5000 and the Bio-1D software (Vilber Lourmat).

Membrane was washed with PBS-Tween, blocked and incubated with a new primary antibody as described above.

$\begin{array}{lll}\text { 10xPBS (1 1) pH7.4: } & 92,3 \mathrm{gr} & \mathrm{NaCl} \\ & 2 \mathrm{gr} & \mathrm{KCl} \\ & 11,5 \mathrm{gr} & \mathrm{Na}_{2} \mathrm{HPO}_{4} \\ & 2 \mathrm{gr} & \mathrm{KHPO}_{4} \\ & & \\ \text { PBS/Tween (2 1) pH 7.4: } & 200 \mathrm{ml} & 10 x \mathrm{PBS} \\ & 1800 \mathrm{ml} & \mathrm{H}_{2} \mathrm{O} \\ & 1 \mathrm{ml} & \text { Tween }\end{array}$

Membranes were stored after use in plastic bags at $4{ }^{\circ} \mathrm{C}$. To verify the results all experiments were repeated at least four times.

For control staining, membranes were incubated with the same concentration of primary antibody pre-absorbed with blocking peptide. $10 \mu \mathrm{l}$ of primary antibody and $50 \mu 1$ of blocking peptide were mixed in $500 \mu \mathrm{PBS}$ and incubated at $4{ }^{\circ} \mathrm{C}$ overnight. Membranes were than incubated with the antibody-peptide mix, diluted in $5 \%$ milkPBS/Tween solution overnight at $4{ }^{\circ} \mathrm{C}$ under gentle agitation. Membranes were then washed with PBS-Tween, blocked and incubated with the appropriate secondary antibody as described above.

\subsubsection{Recombinant DNA techniques}

The $\mathrm{GABA}_{\mathrm{B}} \mathrm{R} 1 \alpha$ gene fragment was cut out from the pCI-neo vector with Nhe I \& Not I and cloned into the pcDNA5/FRT at the same restriction sites (The new plasmid: pcDNA5/FRT- GABA ${ }_{B} R 1 \alpha$, see figure 2.5). The $\mathrm{GABA}_{\mathrm{B}} \mathrm{R} 2$ gene fragment 
was cut with Xho I and inserted to the pBudCE4.1 at the Xho I site (The new plasmid: npBudCE4.1- GABA $A_{B} R 2$, see figure 2.5). The new plasmid, pBudCE4.1- GABA ${ }_{B} R 2$, was digested with $M l u \mathrm{I}$ and $X b a \mathrm{I}$ and ligated to the pcDNA5/FRT-GABA $\mathrm{B} 1 \alpha$ fragment which was cut with Pme I.

The final vector pcDNA5/FRT- GABA $\mathrm{B} 1 \alpha$-npBudCE4.1- $\mathrm{GABA}_{\mathrm{B}} \mathrm{R} 2$ was used to transfect the HEK293 cells. All enzymatic reactions (ligation, dephosphorylation, blunt-end and restriction) were used in order to obtain the final vector are summarized in figure 2.5 .

\subsubsection{GABA $\mathrm{ABNA}_{\mathrm{B}}$}

The $\mathrm{GABA}_{\mathrm{B}}$ receptor cDNAs were derived from Novartis Pharma AG. The GABA receptor 2 and $\mathrm{GABA}_{\mathrm{B}}$ receptor $1 \alpha$ from rat were used for the cloning.

\subsubsection{DNA maxi preparation}

For the preparation of larger amounts of high copy plasmid DNA Qiagen Plasmid Maxi Kit (Qiagen, Hilden, Germany) was used. The procedure was carried out according to the manufacturer's instructions. DNA was stored in 1xTE buffer $(10 \mathrm{ml}$ $1 \mathrm{M}$ Tris $\mathrm{pH} 8.0,2 \mathrm{ml} 0.5 \mathrm{M}$ EDTA $\mathrm{pH} 8.0$, Up to 1 lit with $\mathrm{H}_{2} \mathrm{O}$ ) at $4{ }^{\circ} \mathrm{C}$.

\subsubsection{DNA sequencing}

The sequencing was performed by Fritz Benseler at the Department of Molecular Neurobiology, Max Planck Institute for Experimental Medicine in Göttingen, using the Applied Biosystems 373 DNA sequencer according to Sanger et. al. (1977). Analyses of the sequences were performed using Lasergene software (DNASTAR, Madison, Wisconsin, USA).

\subsubsection{DNA digestion with restriction enzymes}

Restriction digestion is the process of cutting DNA with special enzymes (Restriction Endonucleases). These enzymes recognize and cut, at specific sequences the DNA. 
Restriction analyses were performed as a control for the composition of the DNA (analytical digest) or for cloning purpose (preparative digest).

Analytical digest were performed for $2-3$ hours at $37^{\circ} \mathrm{C}$ in $15 \mu 1$ reaction volume.

Analytical digest mixture:

$1 \mu 1$ DNA

$1.5 \mu 110 \times$ buffer (enzyme specific)

$0.5 \mu 1$ restriction enzyme

$\mathrm{H}_{2} \mathrm{O}$ up to $15 \mu \mathrm{l}$

Preparative digest were performed at $37^{\circ} \mathrm{C}$ in $60 \mu 1$ reaction volume overnight.

Preparative digest mixture:

$4 \mu 1$ DNA

$6 \mu 110 \times$ buffer (enzyme specific)

$2 \mu 1$ Restriction enzyme $(10 \mathrm{U} / \mu \mathrm{l})$

$\mathrm{H}_{2} \mathrm{O}$ up to $60 \mu \mathrm{l}$

DNA fragments obtained from the restriction digestions were directly analyzed by agarose gel electrophoresis.

\subsubsection{Purification of DNA}

DNA fragments were purified by phenol-chloroform extraction or separated on an agarose gel and the fragments of interest were purified using the QIAquick Gel extraction Kit (Qiagen).

- Purification of DNA from agarose gel (see section 2.2.1.4).

- DNA purification (phenol-chloroform extraction) and DNA precipitation 
DNA can be purified by phenol-chloroform extraction to remove proteins from DNA solutions. After restriction digestion or blunting the DNA fragments were purified by phenol-chloroform extraction and then precipitated.

The DNA solution was mixed with 0.1 xvolume $3 \mathrm{M}$ sodium acetate and 1xvolume phenol-chloroform-isoamyl alcohol $(25: 24: 1)$ followed by centrifugation at 13.000 rpm for $10 \mathrm{~min}$. The top aqueous phase (supernatant) was collected and 1xvolume of isopropanol was added followed by brief mixing and incubation for $5 \mathrm{~min}$ on ice. After centrifugation for $15 \mathrm{~min}$ at $13.000 \mathrm{rpm}$ the supernatant was removed and the pellet was washed with $70 \%$ ethanol. The pellet was dried in air and then resuspended in $10 \mu \mathrm{l} \mathrm{dH}_{2} \mathrm{O}$.

\subsubsection{Dephosphorylation of DNA fragments}

To prevent the self-ligation of a vector in ligation reactions (e.g. when a plasmid was cut with only one enzyme or blunt-ended), 5' phosphate groups were removed by hydrolysis. The dephosphorylation was performed using alkaline phosphatase (AP) in $10 \mathrm{x}$ AP dephosphorylation buffer (Boehringer Ingelheim, Germany) for $30 \mathrm{~min}$ at $37^{\circ} \mathrm{C}$.

The following reaction mixture was used:

$60 \mu 1$ vector DNA (after preparative digestion)

$20 \mu 1$ 10xAP dephosphorylation buffer

$2 \mu \mathrm{l}$ AP (alkaline phosphatase)

$120 \mu 1 \mathrm{H}_{2} \mathrm{O}$

\subsubsection{Blunt-end cloning}

Blunt end cloning was performed when no compatible restriction sites were present. After restriction digestion, dephosphorylation and DNA purification from agarose gel slices, blunting was done using Kleenow Polymerase (Boehringer Mannheim GmbH, Germany). 


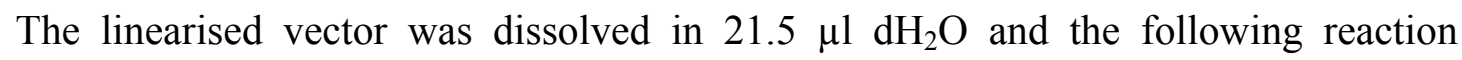
mixture was set up:

$21.5 \mu 1 \mathrm{DNA}$

$2.5 \mu 1$ Kleenow Buffer

$0.5 \mu \mathrm{dNTP} 10 \mathrm{mM}$

$0.5 \mu 1$ Kleenow Polymerase $2 \mathrm{U} / \mu 1$

The reaction was carried out at $37{ }^{\circ} \mathrm{C}$ for $30 \mathrm{~min}$ and the DNA fragments were purified by phenol-chloroform extraction and ethanol precipitation. The blunt-ended Vector and fragment were then used for the ligation reaction.

\subsubsection{Ligation of DNA fragments}

DNA ligations were performed by incubating appropriately treated DNA fragments with an appropriately treated vector and T4 DNA ligase in buffer.

The molar ratio of linear vector to insert fragments was ca 1:10. The components in the table below were mixed in a $1.5 \mathrm{ml}$ tube. The mixture was then incubated at $12{ }^{\circ} \mathrm{C}$ overnight for ligating reaction. A parallel ligation in the absence of insert DNA was performed as a control.

Composition of the ligating reaction:

$1 \mu 1$ vector DNA

$3.5 \mu 1$ insert DNA

$2.5 \mu 1$ 10x ligase buffer

$1 \mu 1 \mathrm{~T} 4$ ligase $(400 \mathrm{U} / \mu \mathrm{l})$

$17 \mu 1 \mathrm{H}_{2} \mathrm{O}$

The ligation mixture was used then for the transformation of E. coli competent cells by electroporation (see section 2.2.3.9). 


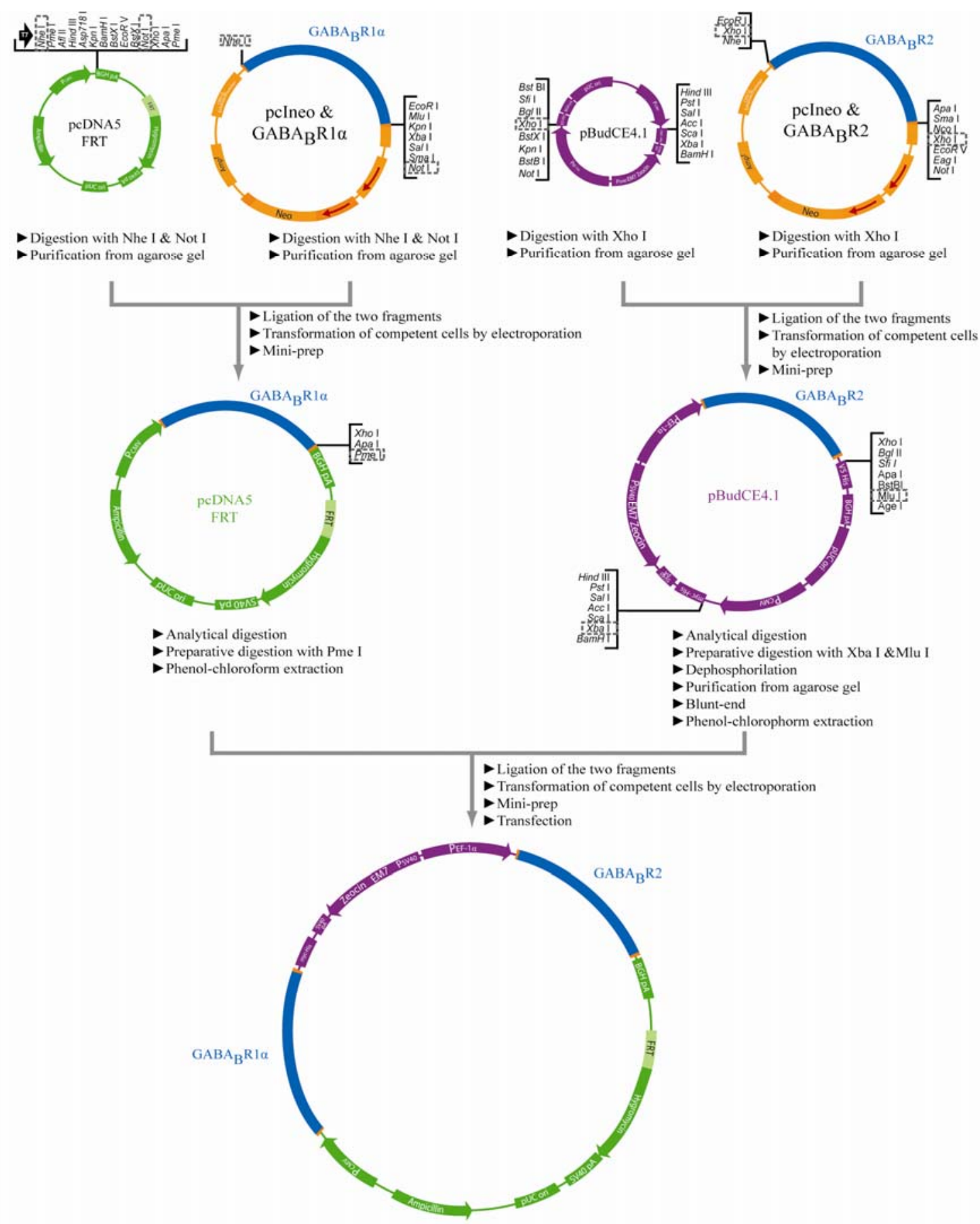

Figure 2.5. The Cloning of the $\mathbf{G A B A}_{\mathbf{B}} \mathbf{R} 1 \alpha$ and $\mathbf{R} 2$ genes. $G A B A_{B} R 1 \alpha$ was cut out from with Nhe I \& Not I and cloned into the pcDNA5/FRT. The GABA $\mathrm{B} 2$ gene fragment was cut with $X$ ho I and inserted to the pBudCE4.1. The new plasmids, pBudCE4.1- $\mathrm{GABA}_{\mathrm{B}} \mathrm{R} 2$, was digested with $M l u$ I and $X b a$ I and ligated to the pcDNA5/FRT-GABA $A_{B}$ R1 $\alpha$ fragment which was cut with Pme I. The final vector was used to transfect the HEK293 cells. 


\subsubsection{Transformation of competent cells by electroporation}

DNA is introduced into competent E. coli cells (Escherichia coli XL1-Blue MRF') by exposing them to a short-high-voltage electrical discharge. $4 \mu 1$ of plasmid DNA (from ligation mixture diluted 1:4 with $\mathrm{dH}_{2} \mathrm{O}$ for Mini-prep, or $4 \mu$ plasmid DNA for Maxiprep) was mixed with $40 \mu 1$ of electro-competent cells in pre-chilled electroporation cuvette and kept on ice for $1 \mathrm{~min}$. The mixture was pulsed at $2.5 \mathrm{kV}$ in a E. coli pulser (BioRad). The transformed cells were then incubated with $1 \mathrm{ml} \mathrm{LB}$ medium at $37{ }^{\circ} \mathrm{C}$ for $1 \mathrm{~h}$ (shaking at $250 \mathrm{rpm}$ ).

For Maxi-prep DNA, $4 \mathrm{ml}$ LB medium with the appropriate antibiotic was added to the cell suspension and incubated for further $4 \mathrm{~h} .100 \mu \mathrm{l}$ of the cells were then added to $500 \mathrm{ml} \mathrm{LB}$ medium with the appropriate antibiotic and incubated overnight at $37^{\circ} \mathrm{C}$.

For the mini-Prep DNA, the cell suspension was plated onto LB agar plates containing the appropriate antibiotic and grown overnight at $37^{\circ} \mathrm{C}$.

\subsubsection{DNA mini preparation}

White colonies were isolated from plates using sterile toothpicks and suspended in 5 $\mathrm{ml}$ of LB medium with the appropriate antibiotic. The colonies were allowed to grow overnight at $37^{\circ} \mathrm{C}$ and $400 \mathrm{rpm}$. The plasmid DNA was isolated from the cells using the QIAprep Spin Miniprep Kit (Qiagen). Briefly, the mini prep DNA was resuspended in $50 \mu$ l of EB buffer $(10 \mathrm{mM}$ Tris- $\mathrm{HCl} \mathrm{pH} 8.5)$ at $4{ }^{\circ} \mathrm{C}$. Purified DNA was analysed by restriction digestion.

\subsubsection{Estimation of DNA concentration}

The concentration of nucleic acids was determined using a spectrophotometer (Eppendorf) by measuring the absorption at $260 \mathrm{~nm}$ of 10 -fold diluted samples in a quartzcuvette. An $\mathrm{OD}_{260}=1$ in a case of $1 \mathrm{~cm}$ cuvette corresponds to $50 \mu \mathrm{g} / \mathrm{ml}$ doublestranded DNA, $33 \mu \mathrm{g} / \mathrm{ml}$ single-stranded DNA and $30 \mu \mathrm{g} / \mathrm{ml}$ oligonucleotides (Sambrook et al., 1989). 


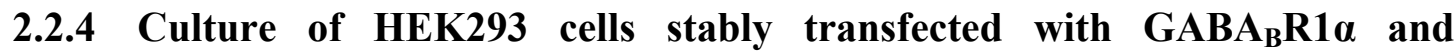 GABA $_{B} R 2$ from rat}

\subsubsection{The Flp-In system}

The Flp-In system was used to generate stable expression cell lines. This System creates isogenic cell lines that means, all transfected clones produce equivalent levels of the protein of interest.

The major components of the Flp-In system are:

- A host cell line, Flp-In HEK 293 cell. The host cell line was generated by stable transfection of the pFRT/lacZeo Vector. The vector contains a lacZ-Zeocin gene whose expression is controlled by the SV40 early promoter. The FRT site is located downstream of the ATG initiation codon of the lacZ-Zeocin gene.

- A plasmid containing a FRT site linked to the hygromycin resistance gene, pcDNA5/FRT, into which the gene of interest can be inserted and expressed under the control of the human cytomegalovirus (CMV). The expression vector was constructed as shown in section 2.2.3 and used in this study.

- A Flp recombinase expression Vector, pOG44, for expression of the Flp recombinase under the control of the human CMV promoter.

The pOG44 plasmid and the pcDNA5/FRT vector containing the gene of interest were cotransfected into the Flp-In host cell line.

Upon cotransfection, the Flp recombinase expressed from pOG44 mediates a homologous recombination event between the Recombination Target (FRT) sites (on host cell line genome and on pcDNA5/FRT-constract) so that the pcDNA5/FRT construct is inserted into the host cell genome, at the integrated FRT site. 


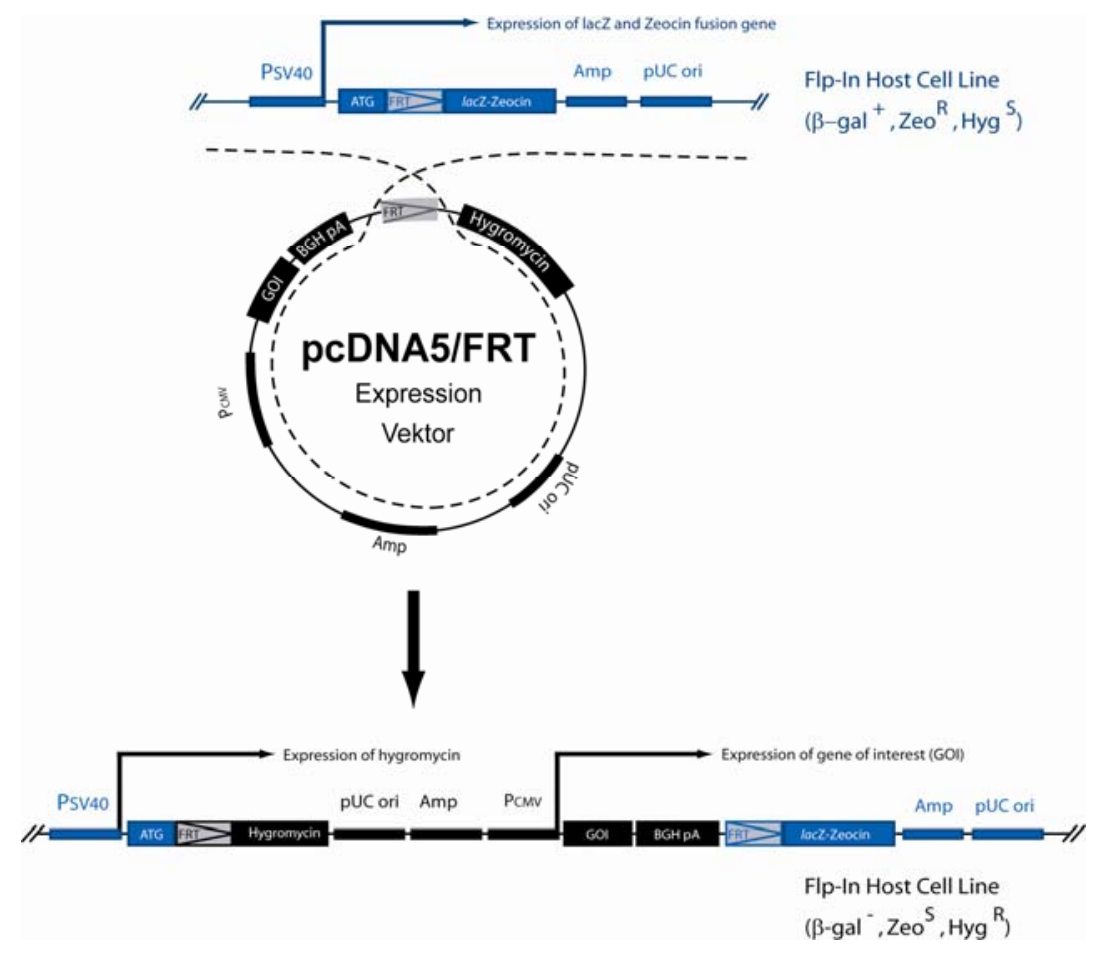

Figure 2.6. Scheme of FLP-In system. (Adapted from the Flp-In system manual, Invitrogen Co.)

Insertion of pcDNA5/FRT into the genome at the FRT site brings the SV40 promoter and the ATG initiation codon (from pFRT/lacZeo) into proximity and frame with the hygromycin resistance gene, and inactivates the lacZ-Zeocin fusion gene. Thus, stable Flp-In expression cell lines can be selected for hygromycin resistance, Zeocin sensitivity, lack of $\beta$-galactosidase activity, and expression of the recombinant protein of interest (see figure 3.1).

\subsubsection{Cell culture and transfection of HEK293 cells}

Flp-In HEK293 cells were maintained in Dulbecco Modified Eagle's Medium (DMEM) containing $2 \mathrm{mM}$ L-Glutamine, $100 \mu \mathrm{g} / \mathrm{ml}$ penicillin-streptomycin and $10 \%$ heat inactivated fetal bovine serum (FBS).

Cells were plated one day before transfection onto $60 \mathrm{~mm} \varnothing$ Petri-dishes to allow attachment of the cells under normal conditions $\left(37^{\circ} \mathrm{C}, 5 \% \mathrm{CO}_{2}\right.$, in DMEM medium 
described above). Cells were cotransfected with pOG44 and the final vector (pcDNA5/FRT-GABA ${ }_{B}$ R1 $\alpha-$ pBudCE4.1-GABA ${ }_{B}$ R2) at a ratio of $1: 1(w / w)$ by means of calcium phosphate precipitation method (MBS mammalian transfection kit). The Flp-In HEK293 cells were grown to 50-80 \% confluence, the medium was changed with a transfection medium (solution 3: Modified Bovine Serum-MBS) and the mixture was drop wise added to the cells.

Transfection mixture for one dish $(60 \mathrm{~mm})$ :

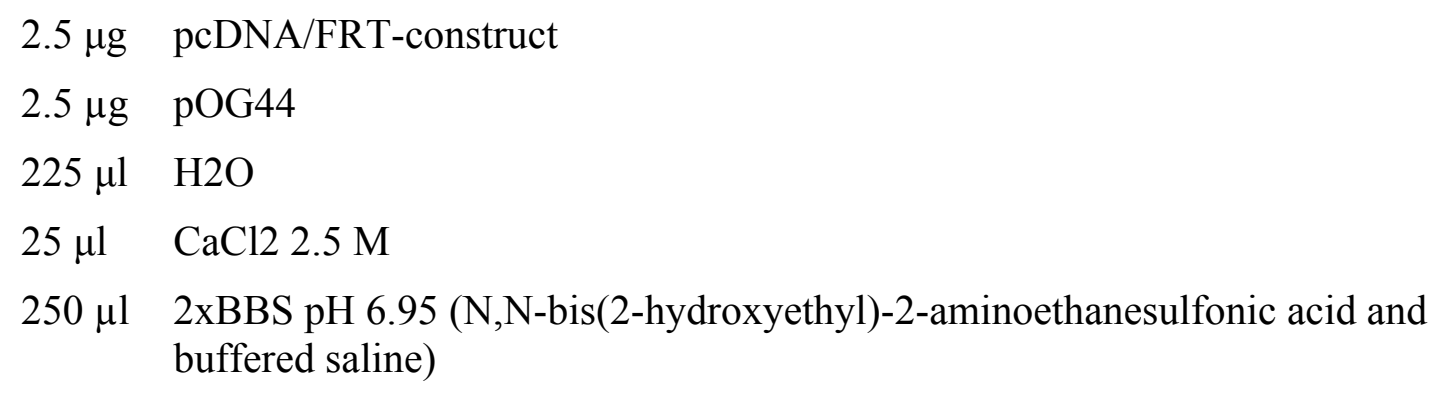

After $3 \mathrm{~h}$ incubation $\left(37^{\circ} \mathrm{C}, 5 \% \mathrm{CO} 2\right)$ the transfection medium was discarded. The cells were further incubated overnight, in fresh culture medium $(2.5 \mathrm{ml}$ per plate: DMEM, $2 \mathrm{mM}$ L-Glutamine, $100 \mu \mathrm{g} / \mathrm{ml}$ penicillin-streptomycin and $10 \% \mathrm{FBS}$ ), at $37^{\circ} \mathrm{C}$ in a $\mathrm{CO}_{2}$ incubator.

The cells were further incubated in culture medium with hygromycin till the foci were formed on the petri-dish. The hygromycin resistance Foci were picked up and analysed for $\beta$-galactosidase expression.

For purposes of further analysis, cells were frozen. The cells were grown to 80-90 \% confluence. The dish was washed with D-PBS and $4 \mathrm{ml}$ culture medium and $2 \mathrm{ml}$ trypsin was applied to detach the cells. Then, cells were transferred to $15 \mathrm{ml}$ Falcon tubes and harvested by centrifugation (1000 rpm for $1 \mathrm{~min})$. The pellet was resuspended in $2 \mathrm{ml}$ of culture medium and $0.5 \mathrm{ml}$ of the resuspended cells were mixed with $0.5 \mathrm{ml}$ freezing medium. The cells were kept in a cryo-freezing box at $-80^{\circ} \mathrm{C}$ for 48 hours before transferred to the liquid nitrogen $\left(-180^{\circ} \mathrm{C}\right)$.

For X-Gal cell staining, cells were grown onto $16 \mathrm{~mm}$ glass cover-slips. For cell lysate preparation, cells were washed with D-PBS, scraped in $1 \mathrm{ml}$ lysis buffer (1h 
incubation at $4{ }^{\circ} \mathrm{C}$ ), centrifuged at $7000 \times \mathrm{g}$ for $10 \mathrm{~min}$ and the supernatant was collected and used for western blotting.

\subsubsection{X-Gal staining}

$\beta$-galactosidase hydrolyzes X-gal (5-bromo-4-chloro-3-indolyl- $\beta$-D-galactoside) to an insoluble dense blue compound 5-bromo-4-chloro-indigo (Horwitz et al., 1964; Davies and Jacob, 1968). Thus, cells expressing ß-galactosidase are stained in blue and can be easily distinguished from those without lacZ expression.

The X-gal staining of the HEK293 cells used in this study was performed in coverslips. Briefly, cells were washed three times with $1 \mathrm{X}$ PBS, and then fixed with $3 \%$ formaldehyde for $5 \mathrm{~min}$ on ice. After fixation, cells were washed three times with 1X PBS and incubated in X-gal staining solution ( $1 \mathrm{ml} \mathrm{DMF,} 40 \mathrm{mg} \mathrm{X-Gal,} 50 \mu 11 \mathrm{M}$ $\mathrm{MgCl}_{2}, 41 \mathrm{mg}$ potassium hexacyanoferrate III, $53 \mathrm{mg}$ potassium hexacyanoferrate II and in $25 \mathrm{ml}$ PBS) for $1 \mathrm{~h}$ at $37^{\circ} \mathrm{C}$.

Stable Flp-In expression cell lines with the $\mathrm{GABA}_{\mathrm{B}}$ receptors can be selected for lack of $\beta$-galactosidase activity. Insertion of pcDNA5/FRT-construct into the genome at the FRT site (see figure 2.6) results in loss of $\beta$-galactosidase activity. Cell lines with inactive $\beta$-galactosidase $\left(\mathrm{lac}^{-}\right)$will remain white and not appropriate transfected clones (lac ${ }^{+}$) will forme blue colonies (see figure 3.1).

\subsection{5 cAMP immunoassay}

The cAMP Biotrak Enzymeimmunoassay (EIA) kit from Amersham Biosciences was used for the cyclic AMP measurements. The assay is based on competition between unlabelled cAMP and a fixed quantity of peroxidase-labelled cAMP, for a limited number of binding sites on a cAMP specific antibody (see figure 2.7).

The assay was performed followed the acetylation EIA procedure (protocol 2), which allows cAMP measurements in tissue extracts where higher sensitivity is required. 
The acetylation assay, the cAMP Biotrak (EIA) includes:

- 96 well plate coated with donkey anti-rabbit IgG

- Assay buffer: $0.05 \mathrm{M}$ sodium acetate buffer, pH 5.8 containing $0.02 \%$ Bovine Serum Albumin and $0.01 \%$ preservative.

- Standard: cAMP standard 10.24 pmol, for acetylation assays in the range 2-128 fmol/well, lyophilised. On reconstitution this bottle contains $2.56 \mathrm{pmol} \mathrm{cAMP} / \mathrm{ml}$.

- Antibody: Rabbit anti-cAMP, lyophilised.

- Peroxidase conjugate: cAMP- Horseradish Peroxidase, lyophilised.

- Wash buffer concentrate: $0.01 \mathrm{M}$ phosphate buffer, pH 7.5 containing $0.05 \%$ Tween ${ }^{\mathrm{TM}} 20$.

- TMB substrate: enzyme substrate containing 3,3',5,5'-Tetramethylbenzidine (TMB)/Hydrogen Peroxide.

- Acetic Anhydride and Triethylamine

Brainstem from neonatal or adult mice was minced and incubated in physiological solution $\left(118 \mathrm{mM} \mathrm{NaCl}, 3 \mathrm{mM} \mathrm{KCl}, 1.5 \mathrm{CaCl}_{2}, 1 \mathrm{mM} \mathrm{MgCl}, 25 \mathrm{NaHCO}_{3}, 1 \mathrm{mM}\right.$ $\mathrm{NaH}_{2} \mathrm{PO}_{4}, 5 \mathrm{mM}$ glucose, equilibrated with carbogen at $25-27{ }^{\circ} \mathrm{C}$ p.H 7.4 in the presence or absence of agonist or antagonist (100 $\mu \mathrm{M}$ baclofen, $50 \mu \mathrm{M}$ CGP 55845A). Samples were stored at $-40{ }^{\circ} \mathrm{C}$.

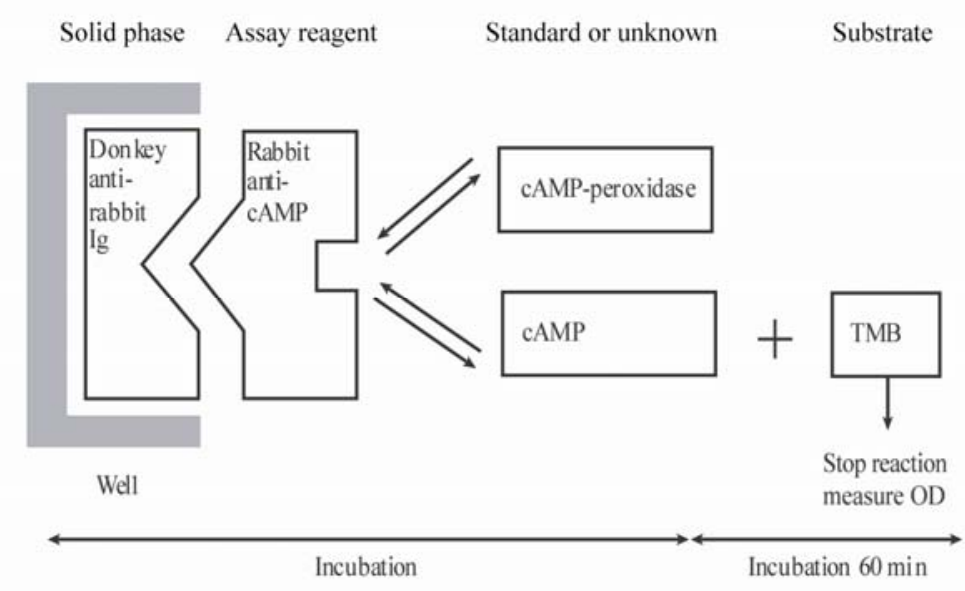

Figure 2.7. Enzyme-immunoassay principle. (Adapted from the cAMP Biotrak EIA System manual, Amersham Biosciences). 
The frozen tissues were homogenized in cold $6 \%(\mathrm{w} / \mathrm{v})$ Trichloroacetic acid at $2-8{ }^{\circ} \mathrm{C}(10 \%(\mathrm{w} / \mathrm{v})$ homogenate). $200 \mu \mathrm{l}$ of the homogenates were centrifuged at $2000 \mathrm{~g}$ for 15 minutes at $4{ }^{\circ} \mathrm{C}$. The supernatant was washed 4 times with 5 volumes of water saturated diethyl ether. The aqueous extract was dried in a dry speedvac ( -80 ${ }^{\circ} \mathrm{C}$ ) and stored at $-40{ }^{\circ} \mathrm{C}$ until use.

The rest of the assay was performed, as described in the kit protocol. Briefly the actual amount of cAMP was determined for each sample in comparison to a standard curve of known amounts of cAMP provided in the cAMP kit.

\subsubsection{GTP binding assay}

\subsubsection{Immunoprecipitation of $\left[{ }^{35} \mathrm{~S}\right] \mathrm{GTP} \gamma \mathrm{S}$-labelled G proteins.}

Mice were decapitated and brainstems were rapidly excised at $4{ }^{\circ} \mathrm{C}$ (see section 2.1.9). The tissue was homogenized using a glass teflon homogenisator in 20 volumes (w/v) of ice-cold Tris- $\mathrm{HCl}$ buffer containing $50 \mathrm{mM}$ Tris- $\mathrm{HCl}(\mathrm{pH} 7.4), 5 \mathrm{mM} \mathrm{MgCl}$ and $1 \mathrm{mM}$ EGTA. The homogenate was centrifuged at $4{ }^{\circ} \mathrm{C}$ for $30 \mathrm{~min}$ at $16000 \mathrm{~g}$. The pellet was resuspended in assay buffer containing $50 \mathrm{mM}$ Tris- $\mathrm{HCl}(\mathrm{pH} 7.4), 5$ $\mathrm{mM} \mathrm{MgCl} 2,1 \mathrm{mM}$ EGTA and $100 \mathrm{mM} \mathrm{NaCl}$ and centrifuged for $30 \mathrm{~min}$ at $16000 \mathrm{~g}$ at $4{ }^{\circ} \mathrm{C}$. The final pellet was resuspended in assay buffer and stored at $-80{ }^{\circ} \mathrm{C}$.

The membrane homogenate (10 $\mu \mathrm{g}$ protein/assay) was resuspended in $70 \mu \mathrm{l}$ of assay buffer with $10 \mu \mathrm{M}$ guanosine-5'-diphosphate (GDP). Reaction mixtures additionally contained $\mathrm{GABA}_{\mathrm{B}} \mathrm{R}$ agonist $\left(100 \mu \mathrm{M}\right.$ baclofen) or $\mathrm{GABA}_{\mathrm{B}} \mathrm{R}$ agonist $(100 \mu \mathrm{M}$ baclofen) preincubated with $\mathrm{GABA}_{\mathrm{B}} \mathrm{R}$ antagonist (10 $\mu \mathrm{M}$ CGP 55845A) or assay buffer as contro).

Incubation was performed at $27{ }^{\circ} \mathrm{C}$ for $1 \mathrm{~h}$ shaking, after adding $\left[{ }^{35} \mathrm{~S}\right] \mathrm{GTP} \gamma \mathrm{S}(1300$ $\mathrm{Ci} / \mathrm{mmol}$ ) to a final concentration of $30 \mathrm{nM}$. The reaction was terminated by adding $140 \mu \mathrm{l}$ of $50 \mathrm{mM}$ Tris- $\mathrm{HCl} \mathrm{pH} 7.4$, containing $20 \mathrm{mM} \mathrm{MgCl}, 150 \mathrm{mM} \mathrm{NaCl}, 0.5 \%$ Nonidet P-40, $200 \mu \mathrm{g} / \mathrm{ml}$ Aprotinin, $100 \mu \mathrm{M}$ GDP and $100 \mu \mathrm{M}$ GTP and incubating on ice for $15 \mathrm{~min}$.

The samples were agitated for $1 \mathrm{~h}$ at $4{ }^{\circ} \mathrm{C}$ with $10 \mu \mathrm{l}$ of appropriate $\mathrm{G} \alpha$ subunitsdirected antibody with $100 \mu \mathrm{l}$ of $10 \%$ suspension of protein A-Sepharose. 
Immunoprecipitates were washed three times, boiled in $0.5 \mathrm{ml}$ of $0.5 \%$ SDS and radioactivity was measured by scintillation spectrometry.

\subsubsection{Immunoprecipitation of Eu-GTP-labelled G proteins.}

The europium-labelled GTP binding assay was performed according to some modifications of the $\left[{ }^{35} \mathrm{~S}\right] \mathrm{GTP} \gamma \mathrm{S}$ binding assay described previously (see section 2.2.6.1).

The membranes were prepared as described above and the homogenate $(10 \mu \mathrm{g}$ protein/assay) was resuspended in $70 \mu \mathrm{l}$ of assay buffer with $10 \mu \mathrm{M}$ GDP. The membrane aliquots contained $100 \mu \mathrm{M}$ baclofen or $100 \mu \mathrm{M}$ baclofen preincubated with $10 \mu \mathrm{M}$ CGP 55845A or assay buffer as control. After a 10 min preincubation at $27{ }^{\circ} \mathrm{C}$ on a plate shaker, $100 \mathrm{nM}$ Eu-GTP was added. Incubation was continued for another $50 \mathrm{~min}$, and the reaction was terminated by adding $140 \mu \mathrm{l}$ of $50 \mathrm{mM}$ Tris- $\mathrm{HCl}$ pH 7.4, containing $20 \mathrm{mM} \mathrm{MgCl}_{2}, 150 \mathrm{mM} \mathrm{NaCl}, 0.5 \%$ Nonidet P-40, $200 \mu \mathrm{g} / \mathrm{ml}$ Aprotinin, $100 \mu \mathrm{M}$ GDP and $100 \mu \mathrm{M}$ GTP and incubating on ice for $10 \mathrm{~min}$.

The samples were agitated for $1 \mathrm{~h}$ at $4{ }^{\circ} \mathrm{C}$ with $10 \mu \mathrm{l}$ of appropriate $\mathrm{G} \alpha$ subunitsdirected antibody with $100 \mu \mathrm{l}$ of $10 \%$ suspension of protein A-Sepharose. Immunoprecipitates were washed three times $(50 \mathrm{mM}$ Tris- $\mathrm{HCl}, \mathrm{pH} 7.4)$ and the pellet was boiled in $0.5 \mathrm{ml}$ of $0.5 \% \mathrm{SDS}$ at $99^{\circ} \mathrm{C}$ for $4 \mathrm{~min}$.

The protein A-Sepharose beads were then pelleted and the supernatant was transferred to a 96 well plate.

The bound Eu-GTP was measured using the factory-set protocol for europium measurements (340 nm excitation/ $615 \mathrm{~nm}$ emission) with the GENios Pro plate reader (Tecan Deutschland $\mathrm{GmbH}$ ). 


\section{RESULTS}

\subsection{Cloning and expression of $G A B A_{B} R 1 a$ and $G A B A_{B} R 2$ from rat in HEK 293 cells}

The first $\mathrm{GABA}_{\mathrm{B}}$ receptor $\mathrm{cDNA}, \mathrm{GABA}_{\mathrm{B}} \mathrm{R} 1 \mathrm{a}$ from rat, was cut out from pcIneo by NheI and NotI endonuclease and subcloned in pcDNA5. Respectively rat GABA ${ }_{B}$ R2 cDNA was cut out from pcIneo by XhoI and subcloned in pBudCE4.1.

The new $\mathrm{GABA}_{\mathrm{B}} \mathrm{R} 1 \mathrm{a}$ and part of the new $\mathrm{GABA}_{\mathrm{B}} \mathrm{R} 2$ constructs were ligated to a pcDNA5-FRT/GABA ${ }_{B} R 1 a \_p B u d C E 4.1 / G A B A_{B} R 2$ final vector (see figure 2.5).

This final construct contained the two $\mathrm{GABA}_{\mathrm{B}}$ receptor subunits which are under the control of the CMV promoter from pcDNA5 (with the $\mathrm{GABA}_{\mathrm{B}} \mathrm{R} 1 \mathrm{a}$ ) and EF-1 $\alpha$ promoter from pBudCE4.1 (with the $\mathrm{GABA}_{\mathrm{B}} \mathrm{R} 2$ ). This construct had in addition an FRT (recombination target) site, which in combination with the pOG44-FLP site, insert into the final construct (with the two $\mathrm{GABA}_{\mathrm{B}}$ subunits) into the integrated FRT site of the Flp-In HEK293 host cell genome. Thus the Flp-In HEK 293 cells were stably expressing the $\mathrm{GABA}_{\mathrm{B}} \mathrm{R} 1 \mathrm{a}$ and $\mathrm{GABA}_{\mathrm{B}} \mathrm{R} 2$ subunits. To detect cell lines that express the receptor, i.e cells with the $\mathrm{GABA}_{\mathrm{B}} \mathrm{R}$ subunit-construct in the proper position (FRT site) of the HEK293 cells, we used X-gal staining. Thus HEK 293 cells stably transfected with $\mathrm{GABA}_{B} \mathrm{R}$ subunits, showed lack of $\beta$-galactosidase activity and they appeared white (see figure 3.1).
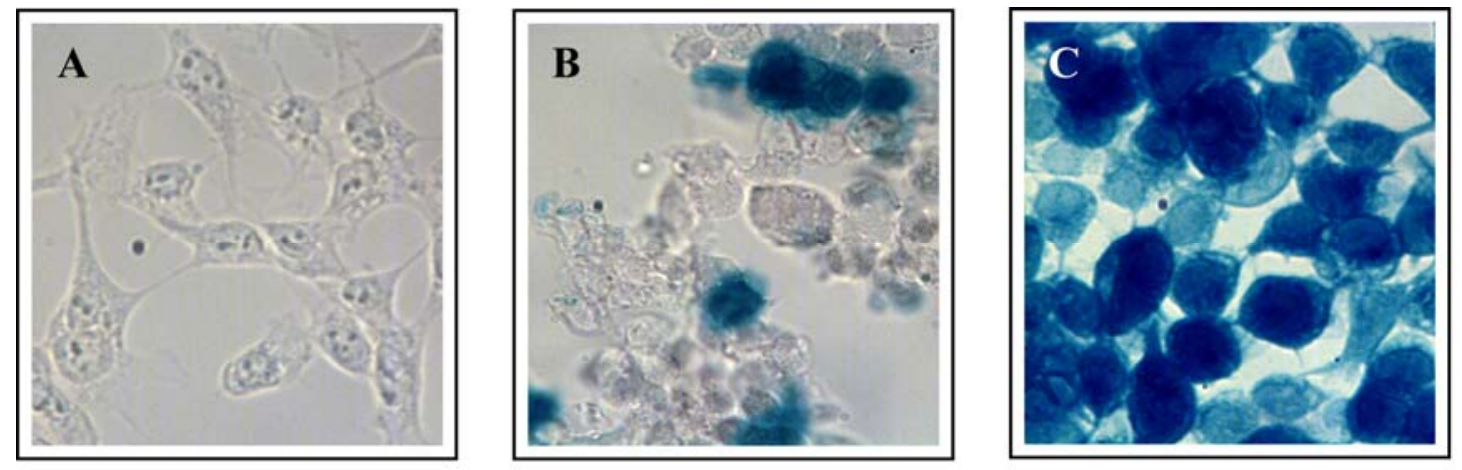

Figure 3.1. X-gal staining of HEK 293 cells stably transfected with $G_{A B} A_{B} R 1 \alpha$ and $\mathrm{GABA}_{\mathrm{B}} \mathrm{R} 2$. Cells expressing $\beta$-galactosidase $\left(\mathrm{lac}^{+}\right)$are stained in blue $(\mathrm{C})$, lac cells that do not express $\beta$-galactosidase remain white. $\mathrm{B}$ shows mixed colonies with $\mathrm{lac}^{+}$ and lac cells. 
To detect co-expression of $\mathrm{GABA}_{B} \mathrm{R} 1 \mathrm{a}$ and $\mathrm{GABA}_{\mathrm{B}} \mathrm{R} 2$, the $\beta$-galactosidase negative cell lines where stained with primary antibodies directed against the $\mathrm{GABA}_{\mathrm{B} 1 \mathrm{a}}$ and $\mathrm{GABA}_{\mathrm{B} 2}$ subunits, and secondary antibodies marked with Cy3 and Cy5. The cells were then analysed by confocal laser scan microscopy, as shown in Figure 3.2.

This immunofluorescence staining showed a proper expression of the $\mathrm{GABA}_{\mathrm{B}} \mathrm{R} 1 \mathrm{a}$ protein mainly on the cell surface of the transfected HEK293 cells.
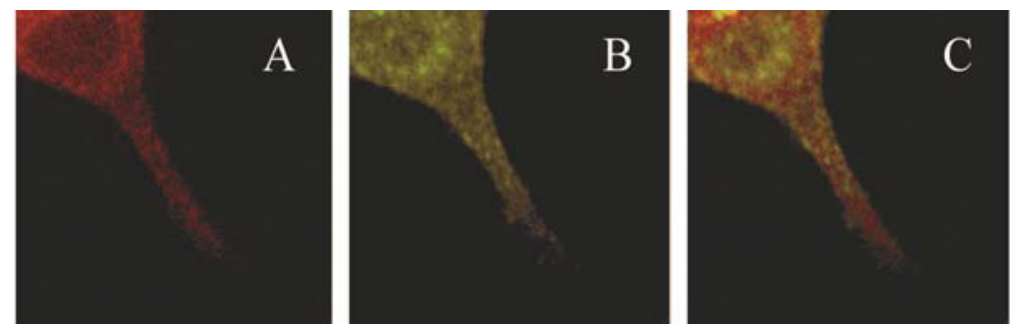

Figure 3.2. Double-labelling of $\mathrm{GABA}_{\mathrm{B}} \mathrm{R} 1 \mathrm{a}$ and $\mathrm{GABA}_{\mathrm{B}} \mathrm{R} 2$ subunits. HEK293 cells stably transfected with $\mathrm{GABA}_{\mathrm{B}} \mathrm{R} 1 \mathrm{a}\left(\mathrm{A}\right.$, red; Cy5) and $\mathrm{GABA}_{\mathrm{B}} \mathrm{R} 2$ (B, green; $\mathrm{Cy} 3$ ). (C) Overlay of panels $\mathrm{A}$ and $\mathrm{B}$ shows that $\mathrm{GABA}_{\mathrm{B}} \mathrm{R} 1 \mathrm{a}$ and $\mathrm{R} 2$ are not co-localized.

In contrast, the $\mathrm{GABA}_{\mathrm{B}} \mathrm{R} 2$ showed an irregular distribution; big spots and mainly intracellular. GABA ${ }_{B} R 1 a$ and $G_{A B A} R 2$ showed no co-localization (Figure 3.2/C). A $3 \mathrm{D}$ picture showed that the $\mathrm{GABA}_{\mathrm{B}} \mathrm{R} 2$ subunit can not reach the surface.

\subsection{Ontogenetic development of the $\mathrm{GABA}_{B}$ receptor in mouse brain}

To examine whether $\mathrm{GABA}_{\mathrm{B}} \mathrm{R}$ shows any age dependant molecular changes, brains from NMRI mice (P0-2 and adult) were analyzed by molecular biological methods. Information about the molecular structure of the $\mathrm{GABA}_{\mathrm{B}}$ receptor was untill recentlly only available from human and rat. To identify the mouse $\mathrm{GABA}_{\mathrm{B} 2}$ receptor $\mathrm{cDNA}$ sequences we performed a BLAST search of the GenBank expressed sequence tag (EST) database using the amino acid sequence of the rat $\mathrm{GABA}_{\mathrm{B}} \mathrm{R} 2$ as the query. $\mathrm{GABA}_{\mathrm{B}} \mathrm{R} 2$ was our subunit of interest, thus this subunit contains all the molecular determinants for $\mathrm{G}$ protein coupling. A mouse $\mathrm{GABA}_{\mathrm{B} 2}$ receptor cDNA was detected (GenBank Accession No. NP_001074610) and in addition a second mouse EST from a new born mouse with a Accession No. XM_143750, predicted as GABA ${ }_{B} R 2$ (http://www.ncbi.nlm.nih.gov/entrez/viewer.fcgi?val=XM_143750.4). An alignment 
of the two detected $\mathrm{GABA}_{\mathrm{B}} \mathrm{R} 2$ sequences the NP_001074610 and the predicted XM_143750.4 shows that the latter one has 35 additional amino acids at the end of the fifth transmembrane region in the intracellular part of the receptor. As our main interest was age related differences at the protein levels of $G_{A B A} R 2$ in the $G$ protein coupling regions (heptahelical domains, intracellular loops and intracellular Cterminal domain) this was a promising difference, which had to be further investigated.

To analyze the eventually altered expression of $\mathrm{GABA}_{\mathrm{B}} \mathrm{R} 2$ between $\mathrm{P} 0$ and adult animals, total RNA was isolated from brainstems and the resulting $\mathrm{GABA}_{\mathrm{B}} \mathrm{R} 2 \mathrm{cDNA}$ was analyzed by sequencing. In detail, RNA from brainstems was isolated with trizol reagent and analyzed by spectrophotometry and reverse transcriptase-PCR (RT-PCR).

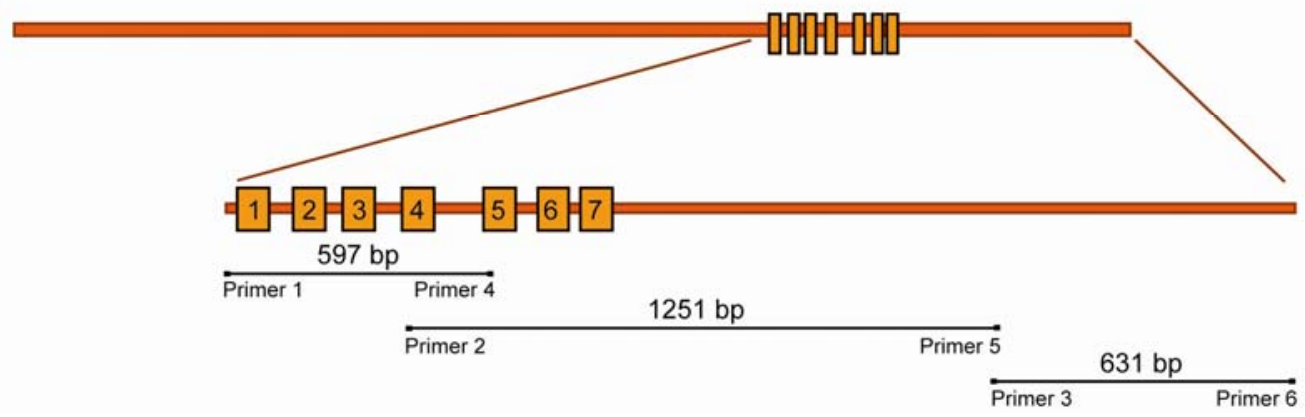

Figure 3.3. Diagram of polymerase chain reaction (PCR) products and relative primer positions on $\mathrm{GABA}_{\mathrm{B}} \mathrm{R} 2 \mathrm{cDNA}$. The upper part illustrates the $\mathrm{GABA}_{\mathrm{B}} \mathrm{R} 2$ protein structure; boxes represent the $7 \mathrm{TMD}$; the line joining them illustrates the $\mathrm{NH}_{2}$, $\mathrm{COOH}$-terminal domains and the inter- and extracellular loops. The mid part is an enlargement of the region of interest 7 TMD and $\mathrm{COOH}$-terminal domain) and the last part shows the PCR primer design regions.

Primer 1: TTCGGAAGATCTCGCTTCCACTGT Primer 4: AACAACCGAACAACATGAGGAGCC

Primer 2: TGCTGATCGATCTGTGCATCCTGA Primer 5: CGCCAAGGAGAAGTCATTGCCATT

Primer 3: TCCTTGGCGTCTGCAAACAAAGAG Primer 6: CCATGGGAGAGGTTAAAGTGCACAA

For the reverse transcription of the mRNA to a complementary DNA (cDNA) we used Omnoscript (Qiagen, Hilden) with $10 \mu \mathrm{g}$ of mRNA as template and the resulting first-strand cDNA was then amplified by PCR. Three primer pairs were designed to amplify three DNA fragments, which screen the receptor $\mathrm{GABA}_{\mathrm{B} 2}$ G-protein coupling regions. The first primer pair 5'-TTCGGAAGATCTCGCTTCCACTGT-3' and 5'- 
AACAACCGAACAACATGAGGAGCC-3', amplifies the GABA B2 $_{2}$ cDNA from the first transmembrane region untill part of the fifth transmembrane region, yielding a fragment of $597 \mathrm{bp}$ after 30 cycles (see figure 3.3). Analog, the second primer pair 5'TGCTGATCGATCTGTGCATCCTGA-3' and 5'-CGCCAAGGAGAAGTCATTGCCATT-3' amplifies the forth transmembrane region till half of the C-terminal region, yielding a fragment of $1251 \mathrm{bp}$ and the third primer pair 5'-TCCTTGGCGTCTGCAAACAAAGAG-3' and 5'-CCATGGGAGAGGTTAAAGTGCACAA-3' yields a fragment of $631 \mathrm{bp}$ which encodes the second half of the C-terminal region till the end of it (see figure 3.3). After amplification the products $(6 \mu \mathrm{l})$ were analyzed on a $1.5 \%$ agarose gel (see figure 3.6). PCR products from adult $\mathrm{GABA}_{\mathrm{B}} \mathrm{R} 2$ with the desired size were identified, as shown in figure 3.6. The three bands with the expected size of 597, 1251 and $631 \mathrm{bp}$ are present in the last three bags of the gel.

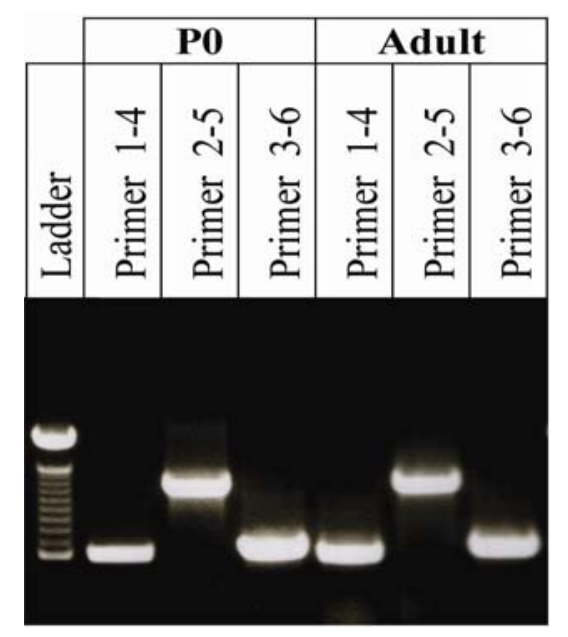

Figure 3.6. Agarose gel showing PCR amplified products obtained using the primer pairs 1-4, 2-5, and 3-6 from newborn and adult mouse brainstem $\mathrm{GABA}_{\mathrm{B}} \mathrm{R} 2$ cDNA. Line 2 to 4 are PCR products from newborn cDNA (597, 1251, and 631 bp respectively); line 5 to 7 are PCR products from adult cDNA (597, 1251, and 631 bp respectively), along with marker DNA (line 1).

In case of the existence of a 35-extra amino acid fragment in the $\mathrm{GABA}_{\mathrm{B}} \mathrm{R} 2$ at the fifth transmembrane region of new born mice, the second PCR product should have a size of $1356 \mathrm{bp}$, but as shown in figure 3.6., the three PCR fragments from new born have the same size as the adult mouse $(597,1251$ and $631 \mathrm{bp})$. Thus, the predicted $\mathrm{GABA}_{\mathrm{B}} \mathrm{R} 2$ protein with the accession No. XM_143750 is not expressed at any of the investigated ages and there is no difference in the expression of the $\mathrm{GABA}_{\mathrm{B} 2}$ receptors between adult and young mice.

In addition, the isolated three cDNA $\mathrm{GABA}_{\mathrm{B}} \mathrm{R} 2$ fragments from both ages were analyzed by sequencing to examine the existence of potential point mutations or any 
other substitute, which can have influence on the expression and eventually the function of $\mathrm{GABA}_{\mathrm{B} 2}$ receptors.

\section{Transmembrane helices 7}

(bp 5602-5664)

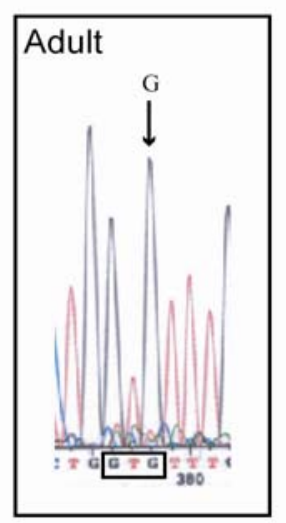

Figure 3.4. Electropherograms showing part of the transmembrane helices 7 sequence in adult and newborn mice. A G to $\mathrm{A} / \mathrm{G}$ substitution at nucleotide position 5658 is marked with an arrow. The marked codon GTG in adult encodes a valine $(\mathrm{V})$. The mixed $\mathrm{A} / \mathrm{G}$ signal at the same position in the P0 mouse does not modify the amino acid. Both triplets GTG and GTA encode valine.

For this reason we isolated and sequenced the six PCR fragments. Sequence analysis revealed differences between adult and newborn mouse genome of $\mathrm{GABA}_{\mathrm{B} 2}$ receptor at the positions 5658 and 5790. The electropherograms (see figure 3.4 and 3.5) show at those positions the two mixed signals in the cDNA of the newborn mice.

\section{C-terminal domain}

(bp 5665-6264)

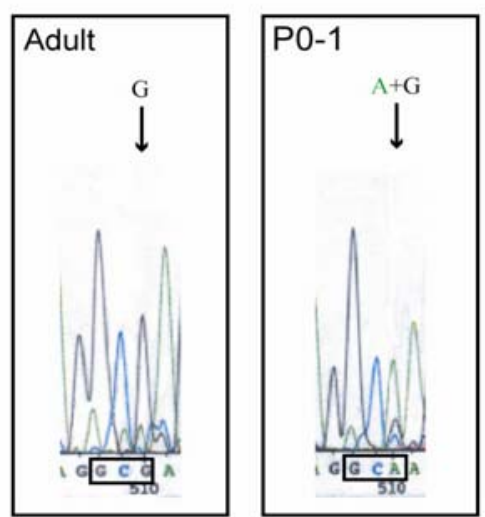

Figure 3.5. Electropherograms showing part of the C-terminal domain sequence in adult and newborn mice. A G to $\mathrm{A} / \mathrm{G}$ substitution at nucleotide position 5790 is marked with an arrow. The marked codon GCG in adult encodes alanin (A). The mixed $\mathrm{A} / \mathrm{G}$ signal at the same position in the P0 mouse does not modify the amino acid. Both triplets GCG and GCA encode alanin.

At the position 5658, which is part of the seventh transmembrane region, the cDNA of the younger mice shows a double peak of adenin and guanin. In contrast to the adult cDNA, shows a single G-peak. The same switch takes place at the position 5790. 
In both cases the G/A switch to $G$ leads to silent mutations. Both codon GTG and GAA (position 5658) encode the amino acid valine and at the position 5790, GCG and GCA encode the amino acid alanin.

Therefore, it can be concluded that there is no change in the expression of $\mathrm{GABA}_{\mathrm{B}}$ receptor 2 in the developing mouse brainsteam.

\subsection{Changes in the $\mathrm{GABA}_{B}$ receptor signaling in the developing mouse brainstem}

$\mathrm{GABA}_{B}$ receptor functionality and selectivity to diverse $G$ proteins subtypes was studied by baclofen stimulated $\left[{ }^{35} \mathrm{~S}\right]-\mathrm{GTP} \gamma \mathrm{S}$ (Harrison and Traynor 2003) and GTPEu binding assay.

The $\left[{ }^{35} \mathrm{~S}\right]-\mathrm{GTP} \gamma \mathrm{S}$-binding assay measures the level of the $\mathrm{G}$ protein activation, following agonist occupation of a GPCR, by determining the binding of $\left[{ }^{35} \mathrm{~S}\right]-\mathrm{GTP} \gamma \mathrm{S}$ to the $\mathrm{G} \alpha$ subunits. In general, the assay is experimentally more feasible for receptors coupled to the abundant $\mathrm{G \alpha}_{\mathrm{i} / \mathrm{o}}$ proteins. Nevertheless, $\left[{ }^{35} \mathrm{~S}\right]-\mathrm{GTP} \gamma \mathrm{S}$ binding assays are used also with GPCRs that couple to the $G \alpha_{s}$ and $G \alpha_{q}$ families of $G$ proteins. For the measurement of the labeled $\mathrm{G} \alpha$ the labeled-G $\alpha$ subunits are immunoprecipitation with $\mathrm{G} \alpha$-antibodies which are cross-linked with protein A-Sepharose.

$\left[{ }^{35} \mathrm{~S}\right]-\mathrm{GTP} \gamma \mathrm{S}$ binding to $\mathrm{GABA}_{\mathrm{B}}$ receptor was performed in young and adult mouse brainstem homogenates. To evaluate whether receptor activation could increase GTP $\gamma \mathrm{S}$ binding, cells were incubated in the presence of a $\mathrm{GABA}_{\mathrm{B}}$ receptor agonist and receptor antagonist. The following immunoprecipitation was then performed with antibodies against $\mathrm{G} \alpha_{\mathrm{i} / \mathrm{o}}, \mathrm{G} \alpha_{\mathrm{i} 3}, \mathrm{G} \alpha_{\mathrm{s}}, \mathrm{G} \alpha_{\mathrm{q} / 11}, \mathrm{G} \alpha_{12}$ and $\mathrm{G} \alpha_{13}$ as described under chapter 2.2.6.1. Fused proteins were then isolated on protein A-Sepharose, and bound $\left[{ }^{35} \mathrm{~S}\right]$ GTP $\gamma$ S was eluted and quantified by scintillation counting.

The experiments were done in duplicate. The figure 3.7 shows the results as the percentage of mean control values. The $\mathrm{G}_{\mathrm{i} / \mathrm{o}}$ subunit showed increase of the bounded $\left[{ }^{35} \mathrm{~S}\right]-\mathrm{GTP} \gamma \mathrm{S}$ after treatment with baclofen and a decrease after the addition of an antagonist, compared to the control (inactivated $\mathrm{GABA}_{\mathrm{B}}$ receptor). It is known that $\mathrm{GABA}_{\mathrm{B}}$ receptors interact with $\mathrm{G} \alpha_{\mathrm{i} / \mathrm{o}}$ proteins, but in addition was observed an increase of $\mathrm{GABA}_{\mathrm{B}}$ receptors binding to $\mathrm{G \alpha}_{\mathrm{i} / \mathrm{o}}$ in newborn mouse brainstem. $\mathrm{GABA}_{\mathrm{B}}$ 
receptors binding affinity to $\mathrm{G} \alpha_{\mathrm{i} 3}, \mathrm{G} \alpha_{12}$ and $\mathrm{G} \alpha_{13}$ shows no interactions between the receptor and those $\mathrm{G} \alpha$ proteins.

A $\mathrm{GABA}_{\mathrm{B}}$-promoted binding of $\mathrm{GTPY}^{35} \mathrm{~S}$ to $\mathrm{G} \alpha_{0}$
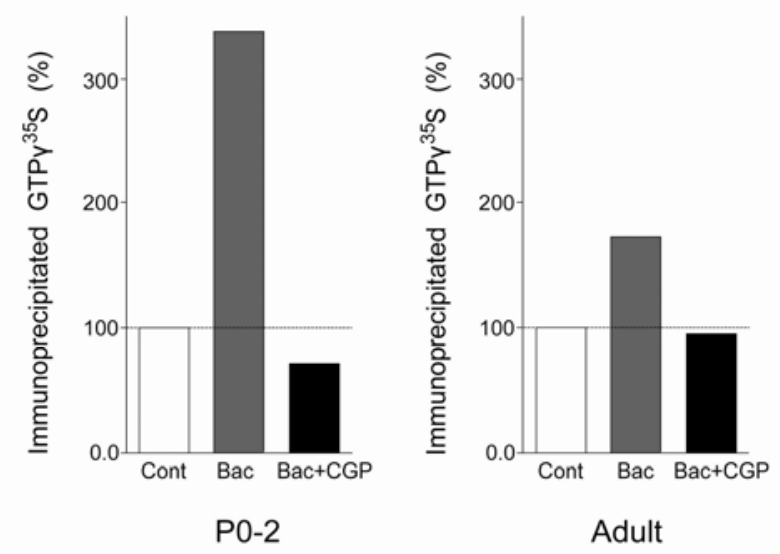

B $\mathrm{GABA}_{\mathrm{B}}$-promoted binding of $\mathrm{GTPY}^{35} \mathrm{~S}$ to $\mathrm{G} \alpha \mathrm{s}$

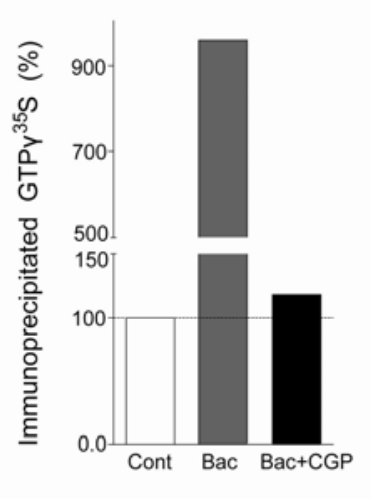

PO

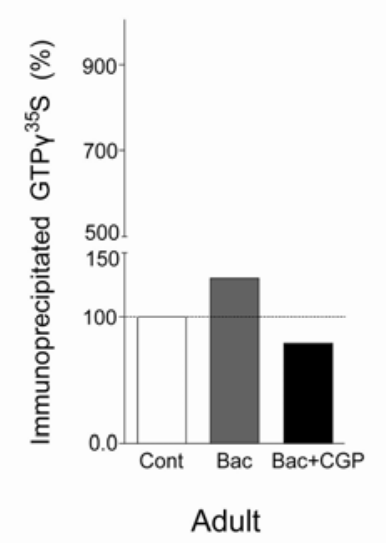

Figure 3.7. The diagram shows $\mathrm{GABA}_{\mathrm{B}}$ receptor agoniststimulated $\left[{ }^{35} \mathrm{~S}\right]-\mathrm{GTP} \gamma \mathrm{S}$ binding to specific $\mathrm{G} \alpha$ protein subtypes in brainstem.

Membranes prepared from brainstem of $\mathrm{P} 0$ and adult mice were incubated with $\left[{ }^{35} \mathrm{~S}\right]-$ GTP $\gamma \mathrm{S}$ in presence of buffer, $100 \mu \mathrm{M}$ baclofen and $10 \mu \mathrm{M}$ CGP 55845A.

Immunoprecipitation was performed with appropriate antibodies against different $\mathrm{G} \alpha$ subunits and bounded $\left[{ }^{35} \mathrm{~S}\right]-$ GTP $\gamma$ S was quantified by scintillation counting. Results were calculated as the percentage of mean control values and represent two independent experiments.

A) Shows, as expected, an increase of the immunoprecipitated $\mathrm{G \alpha}_{\mathrm{i} / \mathrm{o}}$ at both ages after stimulation with baclofen. B) Shows an unexpected dramatical increase of the immunoprecipitated $G \alpha_{s}$ in young animals, which hardly appears at adult mouse brainstem after activation with baclofen.

The figure 3.7.B shows the $\mathrm{GABA}_{\mathrm{B}}$ receptors interaction to $\mathrm{G} \alpha_{\mathrm{s}}$. In this case an unexpected dramatical increase of the immunoprecipitated $\mathrm{G} \alpha_{\mathrm{s}}$ in young animals was observed in contrast to the near negligble shift at adult mouse brainstem after activation with baclofen. As the results showed an unexpected difference of $\mathrm{GABA}_{B}$ receptor interaction to the $\mathrm{G} \alpha_{\mathrm{s}}$ protein subtypes between the two ages ( $\mathrm{P} 0$ and adult), additional experiments were necessary.

Further experiments for the $\mathrm{GABA}_{\mathrm{B}}$ receptor functionality and selectivity to diverse $\mathrm{G}$ proteins subtypes were done with a non-radioactive, non-hydrolyzable, europium 
labeled GTP analogue, the GTP-Eu. The GTP-Eu binding assay yielded similar values to the traditional $\left[{ }^{35} \mathrm{~S}\right]-\mathrm{GTP} \gamma \mathrm{S}$ assay (Frang, Mukkala et al. 2003; Labrecque, Anastassov et al. 2005) but with less intensity. We developed Eu-GTP-binding assay with immunoprecipitation in order to avoid problems involved in working with radioactivity and to help us to increase the number of experiments.

The assay was optimized as described under 'Material and methods'. The young and adult mouse brainstem homogenates were incubated in the presence of a GABA receptor agonist and antagonist together with the europium-labeled GTP.

$\mathrm{GABA}_{\mathrm{B}}$-promoted binding of GTP-Eu to Goio

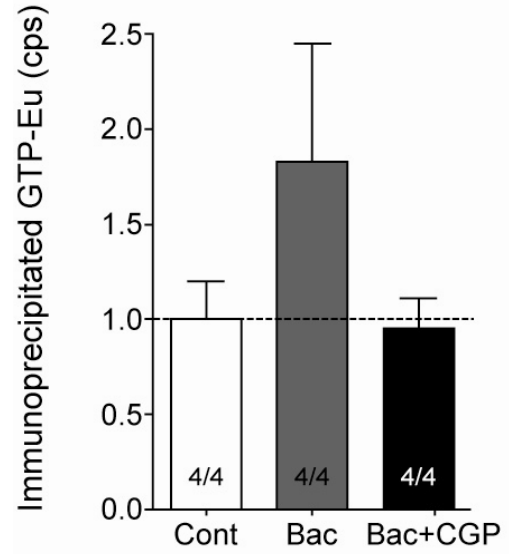

PO

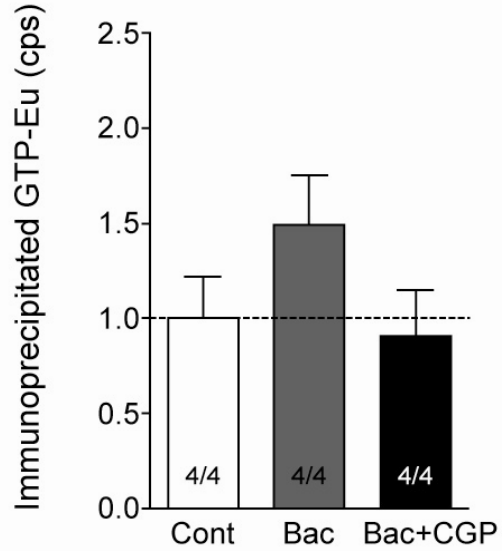

Adult

Figure 3.8. The diagram shows $\mathrm{GABA}_{\mathrm{B}}$ receptor agonist-stimulated Eu-GTP binding to specific $\mathrm{G \alpha}_{\mathrm{i} / \mathrm{o}}$ protein subtypes in brainstem. Membranes prepared from brainstem of P0 and adult mice were incubated with Eu-GTP in presence of buffer, $100 \mu \mathrm{M}$ baclofen and $10 \mu \mathrm{M}$ CGP 55845A. Immunoprecipitation was performed with an antibody against $\mathrm{G \alpha}_{\mathrm{i} / \mathrm{o}}$ subunits and bounded Eu-GTP was quantifie using the autofluorescent properties of $\mathrm{Eu}(340 \mathrm{~nm}$ excitation $/ 615 \mathrm{~nm}$ emission) by using the GENios pro plate reader. The experiments were done in fourplicate and the figure shows the means \pm standard deviation.

The samples were further incubated with antibodies against $\mathrm{G} \alpha_{\mathrm{i} / \mathrm{o}}, \mathrm{G} \alpha_{\mathrm{i} 3}, \mathrm{G} \alpha_{\mathrm{s}}, \mathrm{G} \alpha_{\mathrm{q} / 11}$, $\mathrm{G} \alpha_{12}$ and $\mathrm{G} \alpha_{13}$. The fused proteins were isolated on protein A-Sepharose, and bound Eu-GTP was washed, eluted and quantifie by using the autofluorescent properties of europium (340 $\mathrm{nm}$ excitation and $615 \mathrm{~nm}$ emission). 
The experiments were done in fourplicate. The figures 3.8, 3.9 and 3.10 show the means \pm standard deviation.

The $\mathrm{G}$ protein subunits alpha i3, alpha 12 and alpha 13 did not bind appreciable levels of Eu-GTP, at both ages (P0 and adult), consistent with a minimal level of GDP/EuGTP exchange. In contrast, the subunits alpha i/o (see figure 3.8) and alpha s (see figure 3.9) bound measurable levels at the age of $\mathrm{P} 0$.

\section{$\mathrm{GABA}_{\mathrm{B}}$-promoted binding of GTP-Eu to Gas}

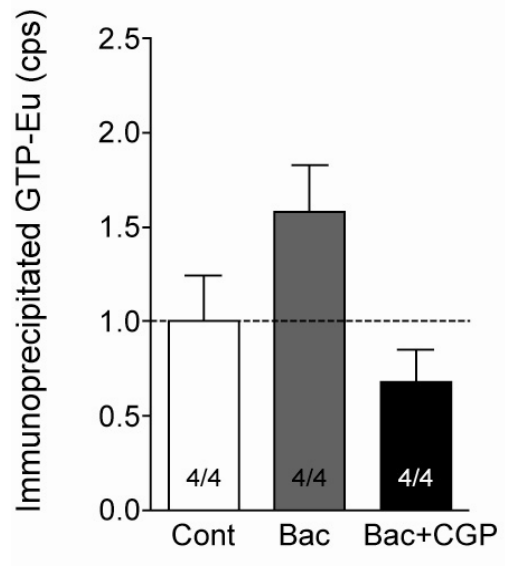

P0

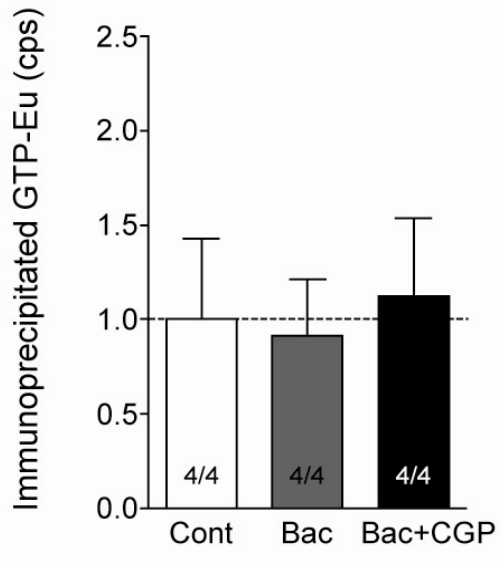

Adult

Figure 3.9. The diagram shows $G_{A B A}$ receptor agonist-stimulated Eu-GTP binding to specific $G \alpha_{s}$ protein subtypes in brainstem. Membranes prepared from brainstem of P0 and adult mice were incubated with Eu-GTP in presence of buffer, $100 \mu \mathrm{M}$ baclofen and $10 \mu \mathrm{M}$ CGP 55845A. Immunoprecipitation was performed with an antibody against $\mathrm{G} \alpha_{\mathrm{s}}$ subunits and bounded Eu-GTP was quantifie using the autofluorescent properties of $\mathrm{Eu}(340 \mathrm{~nm}$ excitation/615 nm emission) by using the GENios pro plate reader. The experiments were done in fourplicate and the figure shows the means \pm standard deviation.

In mature brainstems only the $\mathrm{G}_{\mathrm{i} / \mathrm{o}}$ shows measurable levels of Eu-GTP, the $\mathrm{G} \alpha_{\mathrm{s}}$ binding in adult brainstems was not different compare to control. Binding to $G \alpha_{\mathrm{q} / 11}$ was weak and not significant.

In summary, the results of the Eu-GTP-binding and $\left[{ }^{35} \mathrm{~S}\right]-\mathrm{GTP} \gamma \mathrm{S}$ binding assays with immunoprecipitation confirm the coupling of the $\mathrm{GABA}_{\mathrm{B}}$ receptor to $G \alpha_{\mathrm{i} / \mathrm{o}}$ at both ages in brainstem with more robust increases at younger ages. The $\mathrm{G} \alpha_{\mathrm{i} 3}, \mathrm{G} \alpha_{12}$ and 
$\mathrm{G} \alpha_{13}$ did not show any interaction to $\mathrm{GABA}_{\mathrm{B}}$ receptor. The $\mathrm{G} \alpha_{\mathrm{q} / 11}$ was in both cases not significant (Eu-GTP and $\left[{ }^{35} \mathrm{~S}\right]-\mathrm{GTP} \gamma \mathrm{S}$ ), although there was a weak signal after activation with baclofen. The surprisingly result was the $G \alpha_{\mathrm{s}}$ interaction with the $\mathrm{GABA}_{\mathrm{B}}$ receptors only in new born mice, something which disappears in adult animals.

\subsection{Maturation of the mouse brain is associated with a differential expression of variants of $G$ protein alpha subunits}

To investigate and analyze the expression of the Ga-protein subtypes we had to identify which subtypes exist in mouse. Nineteen $\mathrm{G} \alpha$ protein sequences were collected from Genbank at NCBI by keyword search and sequence similarity using BLAST.

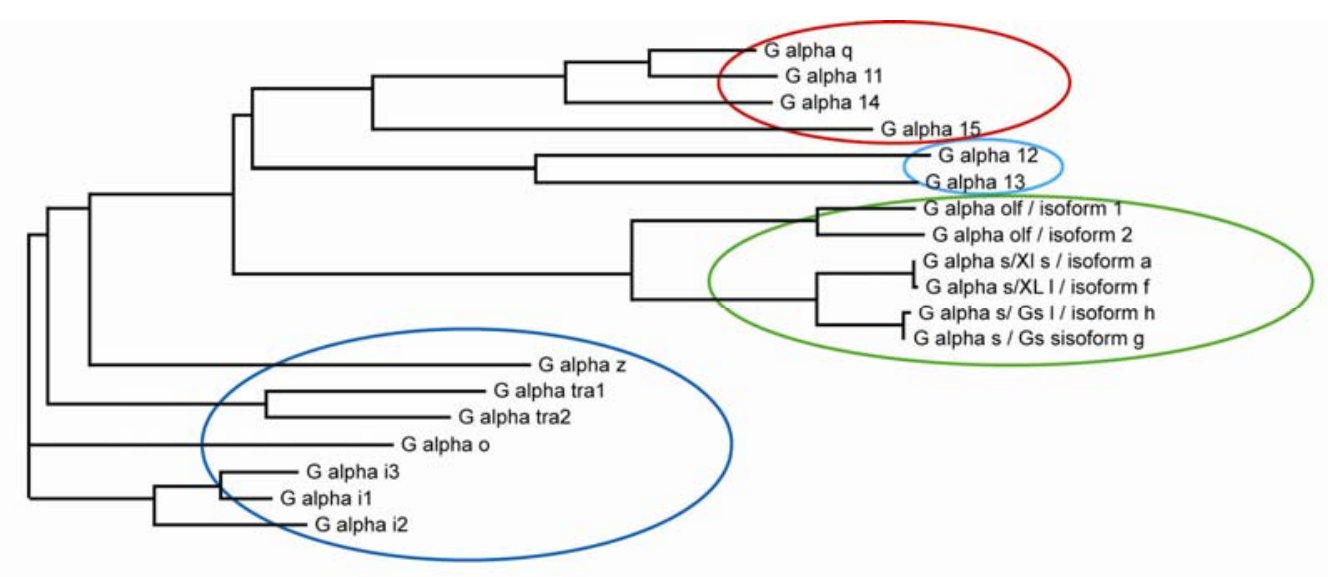

\begin{tabular}{|l|c|}
\hline$G \alpha_{s-f}$ & NP 001070975 \\
\hline$G \alpha_{s-a}$ & NP 034439 \\
\hline$G \alpha_{s-h}$ & NP 963910 \\
\hline$G \alpha_{s-g}$ & NP 001070978 \\
\hline$G \alpha_{\text {i- }-2}$ & NP 032164 \\
\hline
\end{tabular}

\begin{tabular}{|l|l|}
\hline$G \alpha_{o}$ & NP 034438 \\
\hline$G \alpha_{q}$ & NP 032165 \\
\hline$G \alpha_{t 1}$ & NP 032166 \\
\hline$G \alpha_{12}$ & NP 034432 \\
\hline$G \alpha_{z}$ & NP 034441 \\
\hline
\end{tabular}

\begin{tabular}{|l|l|}
\hline$G \alpha_{13}$ & NP 034433 \\
\hline$G \alpha_{15}$ & NP 034434 \\
\hline$G \alpha_{11}$ & NP 034431 \\
\hline$G \alpha_{i 1}$ & NP 034435 \\
\hline$G \alpha_{12}$ & NP 032167 \\
\hline
\end{tabular}

\begin{tabular}{|l|l|}
\hline$G \alpha_{\text {olf-1 }}$ & NP 034437 \\
\hline$G \alpha_{i-3}$ & NP 034436 \\
\hline$G \alpha 14$ & NP 032163 \\
\hline G $\alpha_{\text {olf-2 }}$ & NP 796111 \\
\hline & \\
\hline
\end{tabular}

Figure 3.10. Phylogenetic tree of the mouse Ga subtypes. The phylogenetic tree was constructed from ClustalW multiple sequence alignment of the amino acid sequences of the $\mathrm{G} \alpha$ family members derived from mouse. The $\mathrm{G} \alpha$ amino acid sequences were collected from the National Center of Biotechnology Information (NCBI) database.

The encircled areas represent the four $\mathrm{G} \alpha$ families: $\mathrm{G} \alpha_{\mathrm{s}}, \mathrm{G} \alpha_{12}, \mathrm{G} \alpha_{\mathrm{q}}, \mathrm{G} \alpha_{\mathrm{i}}$. The $\mathrm{G} \alpha_{\mathrm{s}}$ major branch has two main sub branches. One of these contains the $\mathrm{G} \alpha_{\mathrm{s}}$ isoforms olf1 and olf- 2 and the second consists of the $G \alpha_{s}$ isoforms $g, h$ and a, f. In addition, it is not clear if all the $\mathrm{G} \alpha_{\mathrm{s}}$ mouse subtypes are known. 
The sequences were analyzed by multisequence alignments and phylogenetic analysis (see figure 3.10). The phylogenetic tree produced by CLUSTALW organises the proteins by sequence similarity by using the program PHYLIP.

All $\mathrm{G} \alpha$ proteins could be assigned to four known families: $\mathrm{G} \alpha_{\mathrm{s}}, \mathrm{G} \alpha_{12}, \mathrm{G} \alpha_{\mathrm{q}}, \mathrm{G} \alpha_{\mathrm{i}}$. The six primary antibodies that were used in this work represent one or two variants from each family group: $G \alpha_{\mathrm{s}}$ antibody for the $\mathrm{G} \alpha_{\mathrm{s}}$ family; $\mathrm{G} \alpha_{12}$ and $\mathrm{G} \alpha_{13}$ for the $G \alpha_{12}$ family; $\mathrm{G} \alpha_{\mathrm{q} / 11}$ for the $\mathrm{G} \alpha_{\mathrm{q}}$ group; and $\mathrm{G} \alpha_{\mathrm{i}-\mathrm{o}}$ and $\mathrm{G} \alpha_{\mathrm{i} 3}$ representatives for the $\mathrm{G} \alpha_{\mathrm{i}}$ family.

Multisequence alignments from the $\mathrm{G} \alpha$ family members were generated for checking the binding sites recognised by the antibodies, and for the size calculation of the Ga protein subtype variants. This was especially necessary for the $\mathrm{G} \alpha_{\mathrm{s}}$. Thus the GNAS locus encodes many $\mathrm{G} \alpha_{\mathrm{s}}$ variants. In our case the $\mathrm{G} \alpha_{\mathrm{s}}$ (Santa cruz biotechnology, sc823) antibody binds the fourth and part of the fifth exon (see figure 3.11). The third exon which is spliced in almost each second Gnas product is not included in the sequence recognized by the $\mathrm{G} \alpha_{\mathrm{s}}$ antibody. That means that this antibody is able to bind to almost all known splice variants of the $\mathrm{G} \alpha_{\mathrm{s}}$ proteins (see figure 1.2). For example the G $\alpha_{\mathrm{s}}$ short (GenBank Acc. Nr. NP_001070978) and long (GenBank Acc. Nr. NP_963910) isoforms differ in the existence or not of exon 3. The same applies to the GasXL short (GenBank Acc. Nr. NP_001070975) and long (GenBank Acc. Nr. NP_034439) isoforms, they also differ in exon 3. In addition, the antibody should not disturb the interaction between the $G \alpha_{s}$ subunit and $\mathrm{GABA}_{\mathrm{B}}$ receptors. Like other GPCRs, $\mathrm{GABA}_{\mathrm{B}}$ receptors recognize the very $\mathrm{COOH}$ terminus of $\mathrm{G} \alpha$ subunits, encoded by exon 12 in mouse and 13 in human, exons 4 and 5 are in the N-terminus.

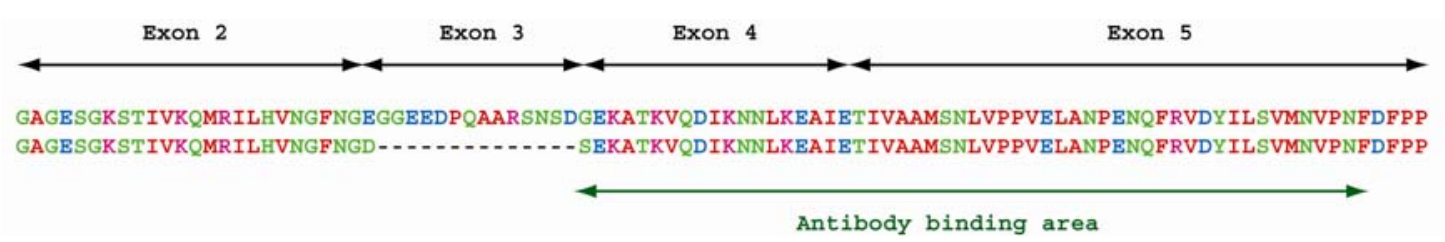

Figure 3.11. Alignment of the $\mathrm{G} \alpha_{\mathrm{s}}$ (short and long subtypes). The alignment of protein sequences was perfomed using ClustalW algorithm. Web Site: www.ebi.ac.uk/clustalw. Residues are colored as follows: red, small and hydrophobic amino acids; blue, acidic; magenta, basic; green, hydroxyl and amine amino acids, including Gln and Tyr. The green line shows the area where the $G \alpha_{\mathrm{s}}$ antibody from Santa cruz (sc-823) binds. 


\subsubsection{Distribution of the $G \alpha_{i / o}$ and $G \alpha_{q / 11}$ proteins in adult and P0 mouse brain areas}

Western blot analyses were performed in order to examine the developmental changes in the distribution of the G $\alpha$ subunits in brainstem. Using SDS PAGE and specific polyclonal antibodies oriented against $\mathrm{G} \alpha_{\mathrm{s}}, \mathrm{G} \alpha_{12}, \mathrm{G} \alpha_{13}, \mathrm{G} \alpha_{\mathrm{q} / 11}, \mathrm{G} \alpha_{\mathrm{i} / \mathrm{o}}$ and $\mathrm{G} \alpha_{\mathrm{i} 3}$, all these proteins were determined by quantitative immunoblotting in homogenates prepared from cortex, cerebellum, and brainstem of P0 and adult animals (see chapter 2.2.2.1-7). The levels of all $\mathrm{G}$ protein $\alpha$ subunits, namely $\mathrm{G} \alpha_{12}, \mathrm{G \alpha}_{13}, \mathrm{G} \alpha_{\mathrm{q} / 11}, \mathrm{G} \alpha_{\mathrm{i} / \mathrm{o}}$ and $\mathrm{G} \alpha_{\mathrm{i} 3}$, were already at birth high. Because of the $\mathrm{G} \alpha_{\mathrm{i} / \mathrm{o}}, \mathrm{G} \alpha_{\mathrm{s}}$ and eventual $\mathrm{G} \alpha_{\mathrm{q} / 11}$ interaction with the $\mathrm{GABA}_{\mathrm{B}}$ receptors, our main interest was focused on these three G $\alpha$ subunits.
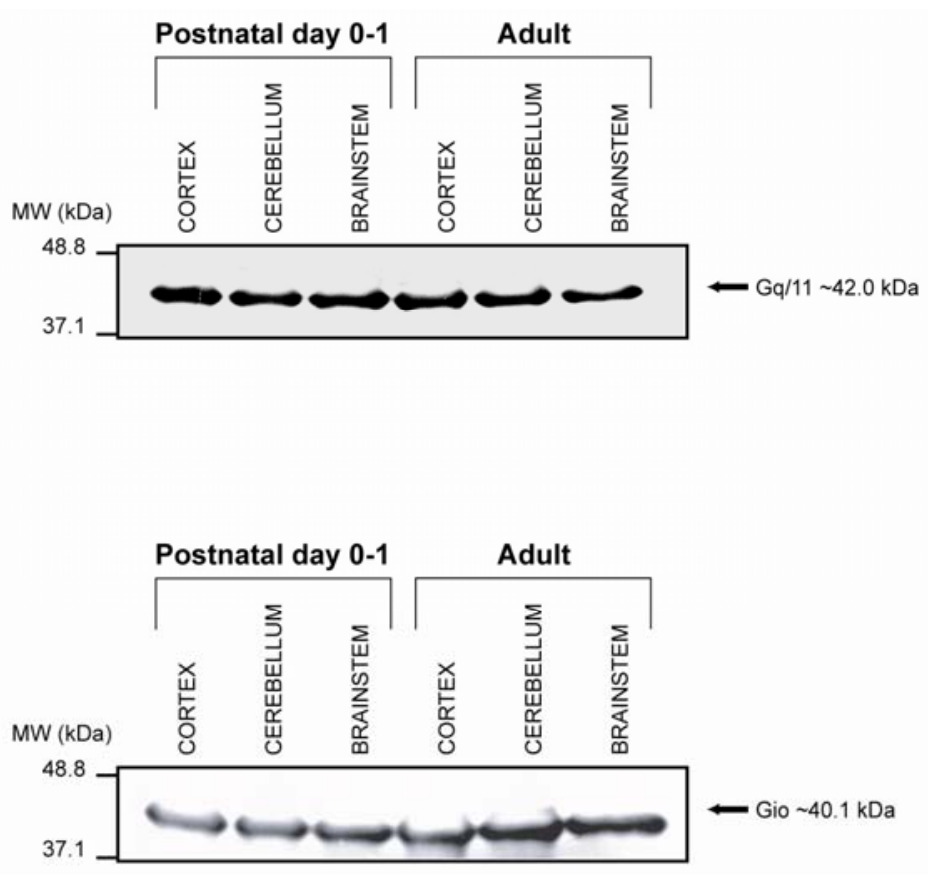

Figure 3.12. The unchanged $\mathrm{G} \alpha_{\mathrm{i}-\mathrm{o}}$ and $\mathrm{G} \alpha_{\mathrm{q} / 11}$ protein levels between different mouse brain areas of adult and newborn mouse. Representative immunoblots showing the distribution of $\mathrm{G \alpha}_{\mathrm{i}-\mathrm{o}}$ and $\mathrm{G} \alpha_{\mathrm{q} / 11}$ in the developing mouse brain areas. Whole cell homogenates $(100 \mu \mathrm{g}$ per lane) were prepared from mouse Cortex, cerebellum and brainstem, resolved by SDS-PAGE and immunobloted with $\mathrm{G} \alpha_{\mathrm{i}-\mathrm{o}}$ or $\mathrm{G} \alpha_{\mathrm{q} / 11}$ antibody (Santa cruz), as described in "Material and Methods". 
A representative immunoblot (figure 3.12) shows that expression of $G \alpha_{\mathrm{i}-\mathrm{o}}$ and $\mathrm{G} \alpha_{\mathrm{q} / 11}$ in cortex, cerebellum and brainstem was basically unchanged during postnatal development. The graph (figure 3.13) summarises densitometry measurements from four independent immunoblots.
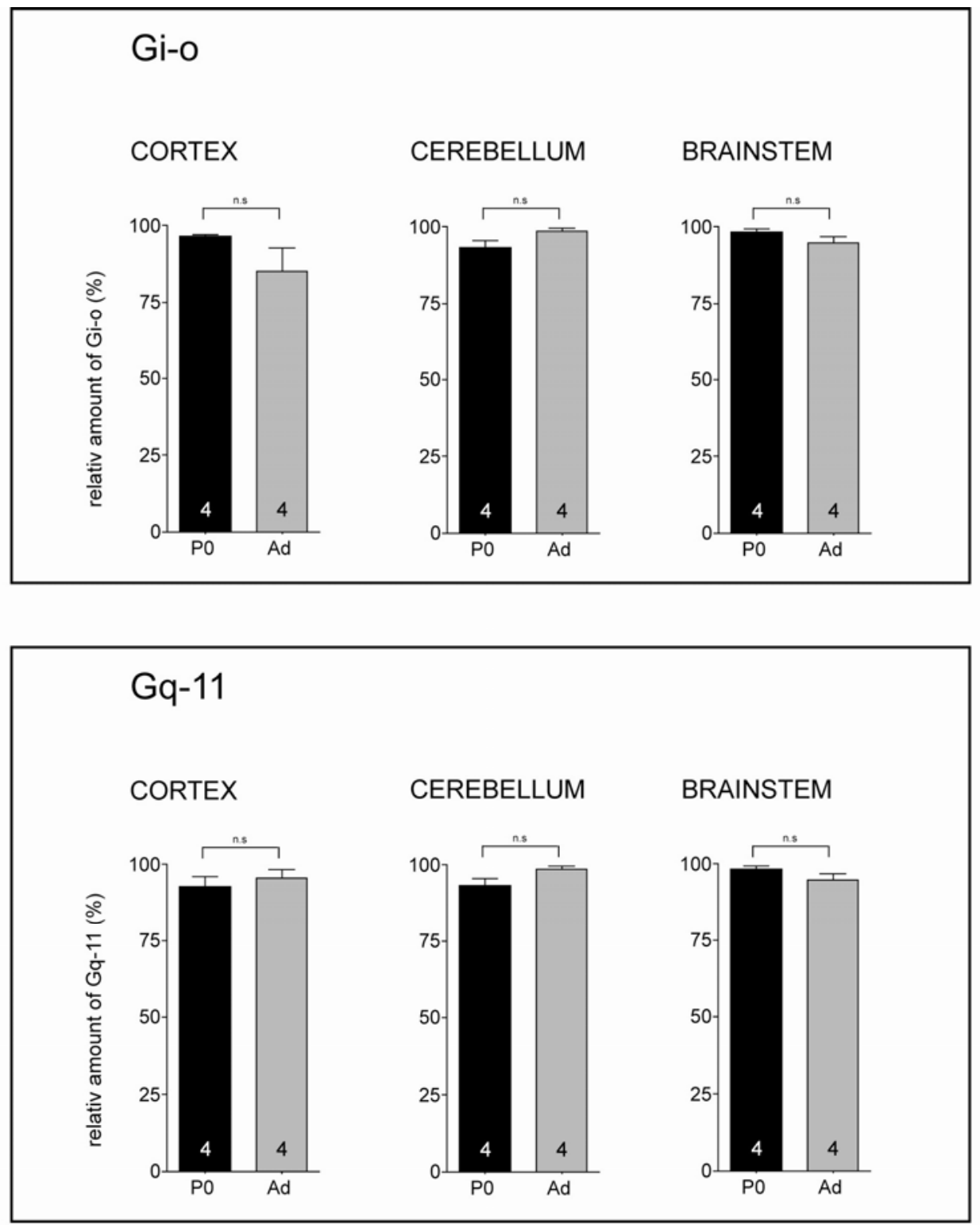

Figure 3.13. No significant changes were observed in the expression of $G \alpha_{i-0}$ and $\mathrm{G} \alpha_{\mathrm{q} / 11}$ proteins between P0 and Adult mouse cortex, cerebellum and brainstem. The graph summarises the densitometry measurements of the immunoblots (Figure 3.13 for $\mathrm{G} \alpha_{\mathrm{i}-\mathrm{o}}$ and $\left.\mathrm{G} \alpha_{\mathrm{q} / 11}\right)$. The proteins $\left(\mathrm{G} \alpha_{\mathrm{i}-\mathrm{o}}\right.$ and $\left.\mathrm{G} \alpha_{\mathrm{q} / 11}\right)$ were quantified by scanning densitometry and then expressed as mean percentages of the maximal values. Data are from four independent immunoblots and represent mean \pm S.E.M (two-tailed). 
In case of the $\mathrm{G} \alpha_{\mathrm{q} / 11}$ antibody the western blot analysis revealed both $\mathrm{G} \alpha_{\mathrm{q}}$ and $\mathrm{G} \alpha_{11}$ subunits. For this reason RT-PCR was performed to examine the expression levels of the two Ga subunits in brainarea-specific and age-dependent manner.

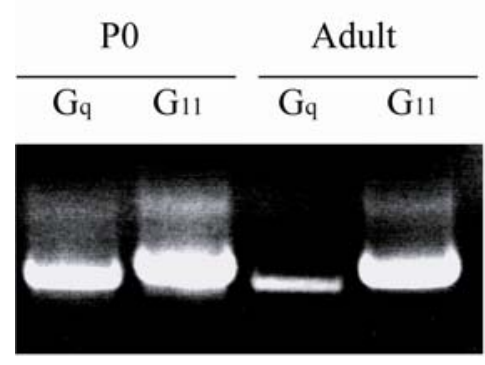

Figure 3.14. Agarose gel electrophoresis of PCR products obtained using the primer pair $\mathrm{G} \alpha_{\mathrm{q}}$ forw-rev and $\mathrm{G} \alpha_{11}$ forw-rev. $\mathrm{G} \alpha_{11}$ showes no age-dependent differences while $\mathrm{G} \alpha_{\mathrm{q}}$ shows a reduce of the mouse brainstem RNA during maturation.

Primer Gq forw: GCCAAGGAAGCCCGGAGGAT

Primer Gq rev: TCAGGATGAATTCTCGAGCTGCCT

Primer G11 forw: CATCAACGCGGAGATCGAGAAAC

Primer G11 rev: CTGCGAACACAAAGCGGATGTTC

RNA was isolated from brainstems of P0 and adult mice and analyzed by RT-PCR. For the following PCR two primer pairs were designed to amplify the $\mathrm{G} \alpha_{\mathrm{q}}$ (primer forw. GCCAAGGAAGCCCGGAGGAT; rev. TCAGGATGAATTCTCGAGCTGCCT) and $\mathrm{G}_{11}$ DNA fragments (primer forw. CATCAACGCGGAGATCGAGAAAC; rev. CTGCGAACACAAAGCGGATGTTC). After amplification, the products were analyzed on a $1.5 \%$ agarose gel (see figure 3.14). Although no difference was observed in the G11 RNA a significant decrease of the Gq RNA was observed in brain stem during aging.

\subsubsection{Distribution of the $\mathrm{G \alpha}_{\mathrm{s}}$ protein subtypes in adult and P0 mouse brain areas}

Developmental changes in the distribution of $\mathrm{G} \alpha_{\mathrm{s}}$ were investigated in the mouse brainstem during postnatal development (P0 and adult) by western blot analyses and densitometry measurements of four independent immunoblots showing above (see chapter 3.4.1).

We screened for $\alpha$ subunit splice variants of the stimulatory G protein family in whole cell homogenate of cortex, cerebellum, and brainstem from mouse and examined the expression of these splice variants during the course of postnatal development. The western blots revealed six bands with a totally different expression pattern during the 
development of the mouse brainstem (see figure 3.15). All six bands disappear in control blots containing the blocking peptide for the $\mathrm{G} \alpha_{\mathrm{s}}$ antibody.

The protein size of these bands was calculated with the help of molecular weight markers, which were run simultaneously with the samples. In addition, the Bio-1D (Vilber Lourmet) software was used to calculate the fragment sizes of the bands with reference to molecular size markers.
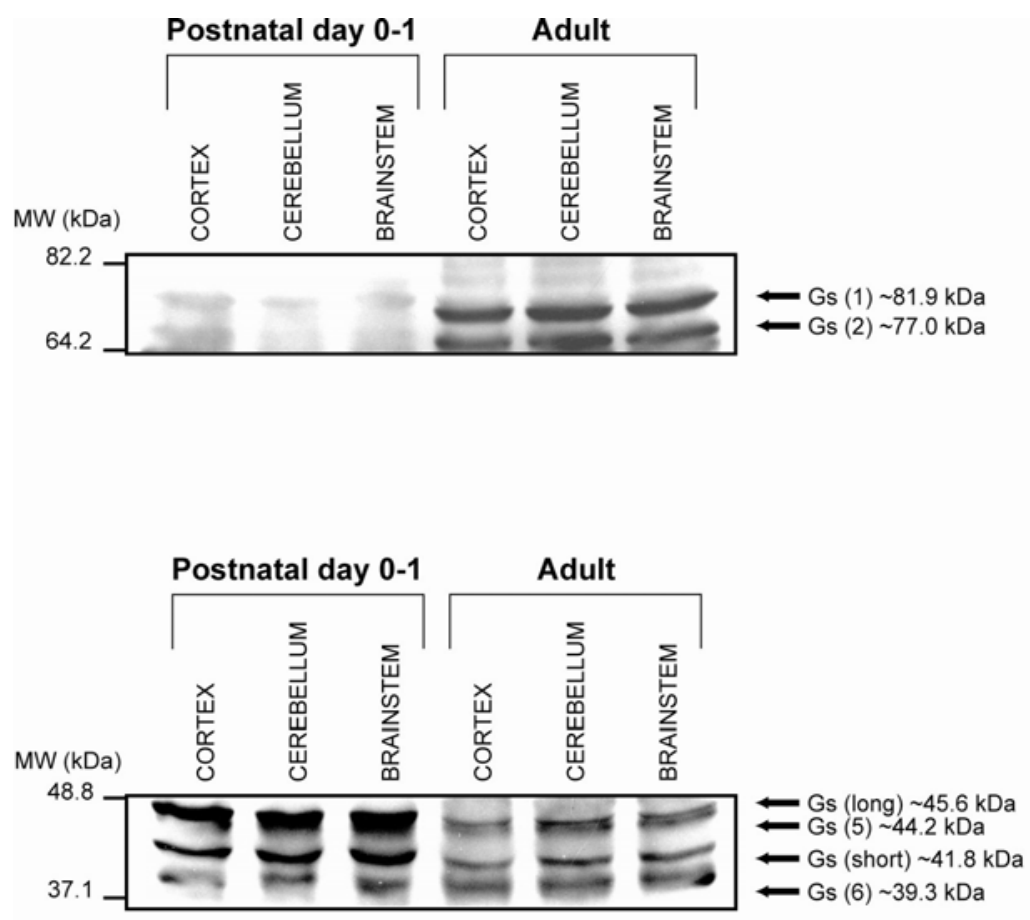

Figure 3.15. There is an age dependent $\mathrm{G} \alpha_{\mathrm{s}}$ subtypes expression in mouse brain areas. Representative immunoblots show the distribution of the $\mathrm{G} \alpha_{\mathrm{s}}$ isoforms in the developing mouse brain areas. Whole cell homogenates (100 $\mu \mathrm{g}$ per lane) were prepared from mouse cortex, cerebellum and brainstem, followed by immunoblotting for a commercial $\mathrm{G} \alpha_{\mathrm{s}}$ antibody (Santa cruz), as described in "Material and Methods". Immunoblots are representative of four experiments.

The band intensity on the immunoblots was quantified using a scanning densitometer and is expressed as a percentage of the highest value (see figure 3.16).

The complexity of the GNAS locus, the number of alternative splice $G \alpha_{s}$ variants in combination with the conflicting reports and the continuously new data made it difficult to identify which band size represents which $\mathrm{G} \alpha_{\mathrm{s}}$ variant. 
The long (GasS) and short (GasL) variants of $G \alpha_{s}$ with a molecular mass of 42 and 45 kDa respectively (see chapter 1.3.1.1), were relativelly easy to identify. Thus, the 41.8 and $45.6 \mathrm{kDa}$ immunoreactive bands were interpreted as being the small (GasS) and large (GasL) forms of $\mathrm{G} \alpha_{\mathrm{s}}$ respectively. Both splice variants show an increase of the total amount during postnatal development in all three brain areas.

An additional minor band of $44.2 \mathrm{kDa}$ (called Gs 5), between the short and long variant of $G \alpha_{\mathrm{s}}$ was observed. This band has a similar expression pattern to the short and long $G \alpha_{s}$ variants, with an increase of the total amount during postnatal development. Nevertheless, the size of this band does not correlate to any known $\mathrm{G} \alpha_{\mathrm{s}}$ variant.

An other $G \alpha_{\mathrm{s}}$ variant (called 6 in figure 3.15), which size does not represent any till now identified $\mathrm{G} \alpha_{\mathrm{s}}$ variant has the size of $39.3 \mathrm{kDa}$ and shows an insignificant slightly increase, during development, in brainstem and a significant increase in cerebellum and cortex.

The two bands $\left(G \alpha_{s} 1 \& 2\right)$ with a size between the marker-lines of 64 and $82 \mathrm{kDa}$ were observed mainly in adult brains. Based on band size (approx. 81.9 and $77 \mathrm{kDa}$ ) and the binding properties of the G $\alpha_{\mathrm{s}}$ antibody (see figure 3.11) we interpreted them as XLas isoforms. The exact size as well as the number of the XLas isoforms is still variate between different reports and data from the GenBank.

There are reports describing the XLas as a $78 \mathrm{kDa}$ (Klemke, Pasolli et al. 2000; Pasolli, Klemke et al. 2000), 92kDa (Kehlenbach, Matthey et al. 1994), 94 kDa (Bastepe, Gunes et al. 2002), and $98 \mathrm{kDa}$ (Freson, Jaeken et al. 2003) protein. Research done on the GenBank showed that there are at least three different XLas isoforms:

$\begin{array}{llll}\text { Name } & \text { GenBank Accession No } & \text { Size (bp) } & \text { Size (kDa) } \\ \text { isoform f } & \text { NP_001070975 } & 1119 & 120.1 \\ \text { Isoforms a } & \text { NP_034439 } & 1133 & 121.5 \\ \text { G protein XL } \alpha & \text { AF116268 } & 756 & 82.3\end{array}$

The size of these proteins was measured with protein calculations software.

In summary, these results demonstrate that expression levels of G $\alpha$ subtypes in whole cell membrane homogenate in cortex, cerebellum and brainstem do not vary in a region specific manner, although alteration in the expression of the $G \alpha_{\mathrm{s}}$ splice variants 
and $\mathrm{G} \alpha_{\mathrm{q}}$ is observed. The rest of the investigated $\mathrm{G} \alpha(\mathrm{i} / \mathrm{o}, 11,12,13, \mathrm{i} 3)$ proteins remains constant also in an age- specific manner.
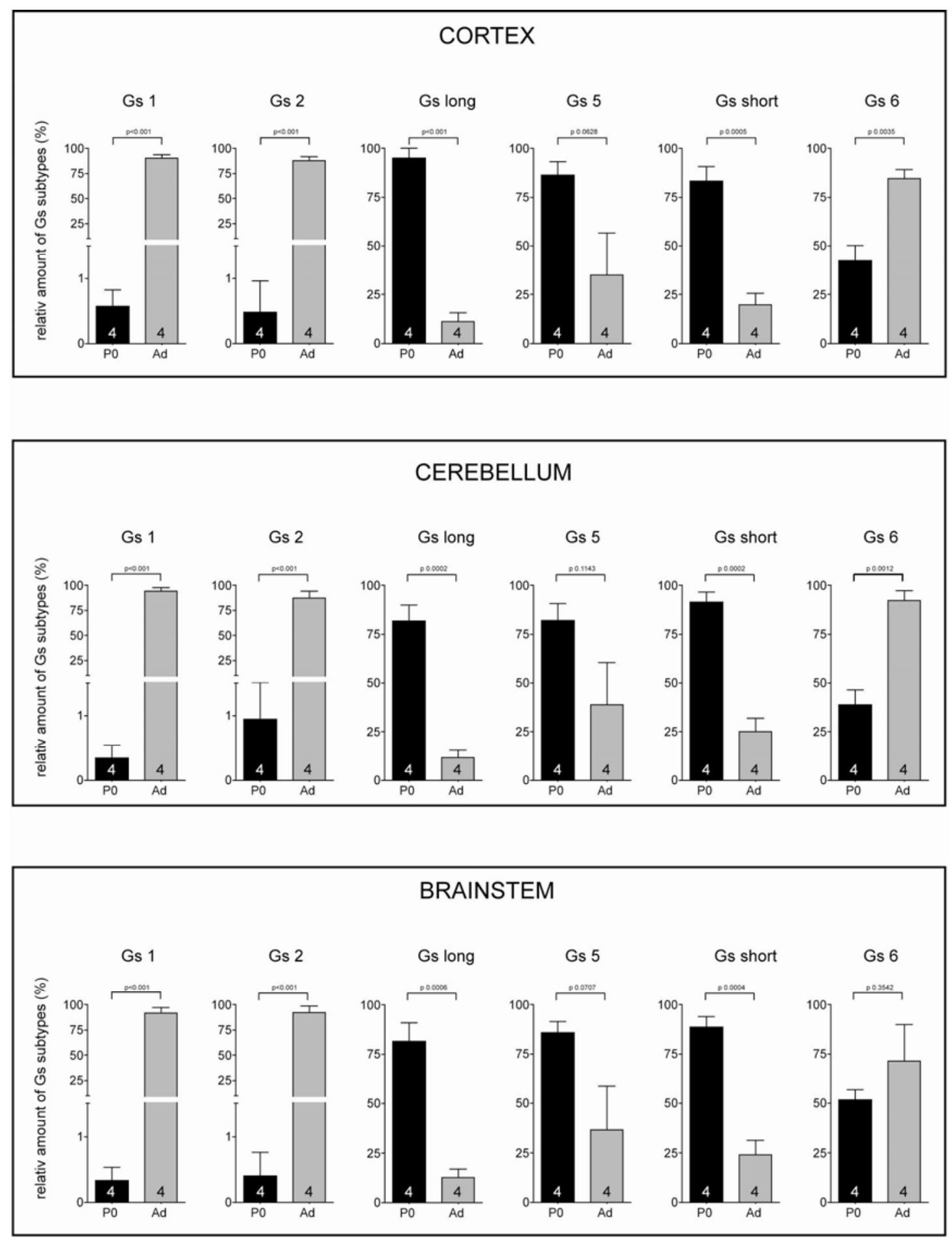

Figure 3.16. The differential distribution of $\mathrm{G}_{\mathrm{s}}$ subtypes between adult and newborn mice, in different brain areas. Immunoblot data (see figure 3.15) were quantified using scanning densitometry, and expressed as mean percentages of the maximal value of each isoform. The data are from four independent experiments and represent mean \pm S.E.M (two-tailed). 
Although the complexity of the GNAS locus and its products did not permit us to distinguish which band exactly correlates with which certain $G \alpha_{\mathrm{s}}$ variant, we show an increase of the short $\mathrm{G} \alpha_{\mathrm{s}}$ subtype variants and a sharp elevation in the expression of the long $G \alpha_{s}$ subtype in newborn animals comparing to adults. The most intense alteration in the expression of $\mathrm{G} \alpha_{\mathrm{s}}$ isoforms during maturation was observed in two bands, which were interpreted as XLas subtypes.

\section{5 cAMP levels in mouse brainstem after activation with baclofen}

Activation of $\mathrm{G} \alpha_{\mathrm{s}}$-protein-coupled receptors is associated with activation of adenylate cyclase, which in turn promotes a cAMP production. Thus, the cAMP levels were measured by enzymeimmunoassay, as described in chapter 2.2.5.
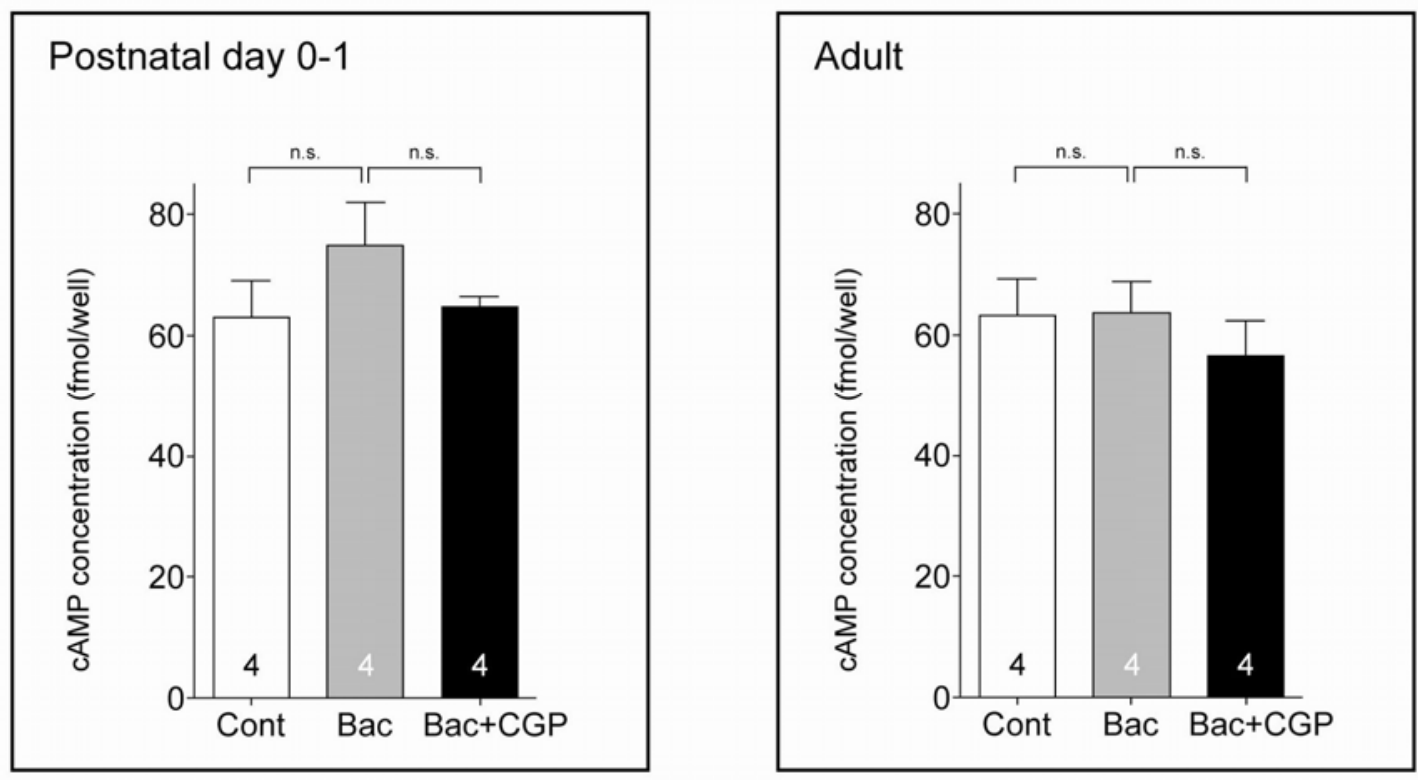

Figure 3.17. Measurement of cyclic AMP (cAMP) in the brainstem of mouse. No significant $\mathrm{cAMP}$ production in adult and neonatal mice brainstems after activation of $\mathrm{GABA}_{\mathrm{B}}$ receptors was observed. Activation of $\mathrm{GABA}_{\mathrm{B}}$ receptors has no influence on the cAMP levels in adult mice brainstems. The new born mice brainstems, after stimulation of $\mathrm{GABA}_{B}$ receptors, show a slight increase of the cAMP levels that was not statistically significant. The cAMP measurement procedure from tissue (mouse brainstem) was determinate as described at "Material and Methods". Tissue from mouse brainstem, were preincubated with baclofen $(100 \mu \mathrm{M})$ and as second control with CGP55845 $(50 \mu \mathrm{M})$ and baclofen. The cAMP levels were determined by enzyme immunoassay (cAMP Biotrak; Amersham Biosciences). The average values of four independent experiments are expressed as the mean \pm S.E.M (two-tailed; unpaired ttest). 
As shown in figure 3.17, the increase of cAMP concentration observed between agonist (baclofen), and the absence of agonist, induced stimulation of $\mathrm{GABA}_{B}$ receptors was not statistically significant. Although the effect on $\mathrm{GABA}_{\mathrm{B}}$-dependent cAMP production was not significant, there was a slightly increase of baclofen induced stimulation on the $\mathrm{GABA}_{\mathrm{B}}$ receptors in neonatal brainstems, and a differential pattern of response between the neonatal and adult mice brainstem.

\subsection{Developmental changes of the GABAergig system}

Until now, all results were related to the developmental changes mediated by $\mathrm{GABA}_{B}$ receptors. Additional experiments associated with another receptor of the GABAergic system, the $\mathrm{GABA}_{\mathrm{A}}$ were performed on the example of Rett syndrome, a disorder of abnormal neuronal maturation which is connected with a synaptic imbalance.

\subsubsection{A disruption in the balance between excitatory and inhibitory receptors: neurodevelopmental disorder (MECP2)}

One of the symptoms of Rett syndrome patients and mecp2 mutant mice is the breathing abnormalities, like hyperventilation and apnea. For this reason we employed the pre-Bötzinger complex (PBC), an area in the medulla which is important for the generation of inspiratory activity, for further experiments. The mecp2 mutant mice that were used as a model system to study the disease mechanism, were at the age of P7, an age at which the Rett syndrome symptoms are not manifested yet.

Electrophysiological experiments indicate that mecp2 $\mathrm{KO}$ mice show, in comparison to the WT mice, a marked depression of inhibitory activity at the cellular level (in press L. Medrihan et al. 2007). In the network of respiratory neurons in the brainstem, GABA and glycin are the two major inhibitory neurotransmitters. Thus, we investigated the expression levels of the $\mathrm{GABA}_{\mathrm{A}}$ receptor subtypes as well as those of glycin, at normal (wild type 'WT') and knockout (KO) mice of the same age. To this purpose we performed western blot analyses and densitometry measurements(see figure 3.18). 
No change was observed in the expression of the glycin receptors. The electrophysiological experiments also showed no alteration in the glycin-mediated activity (in press L. Medrihan et al. 2007).

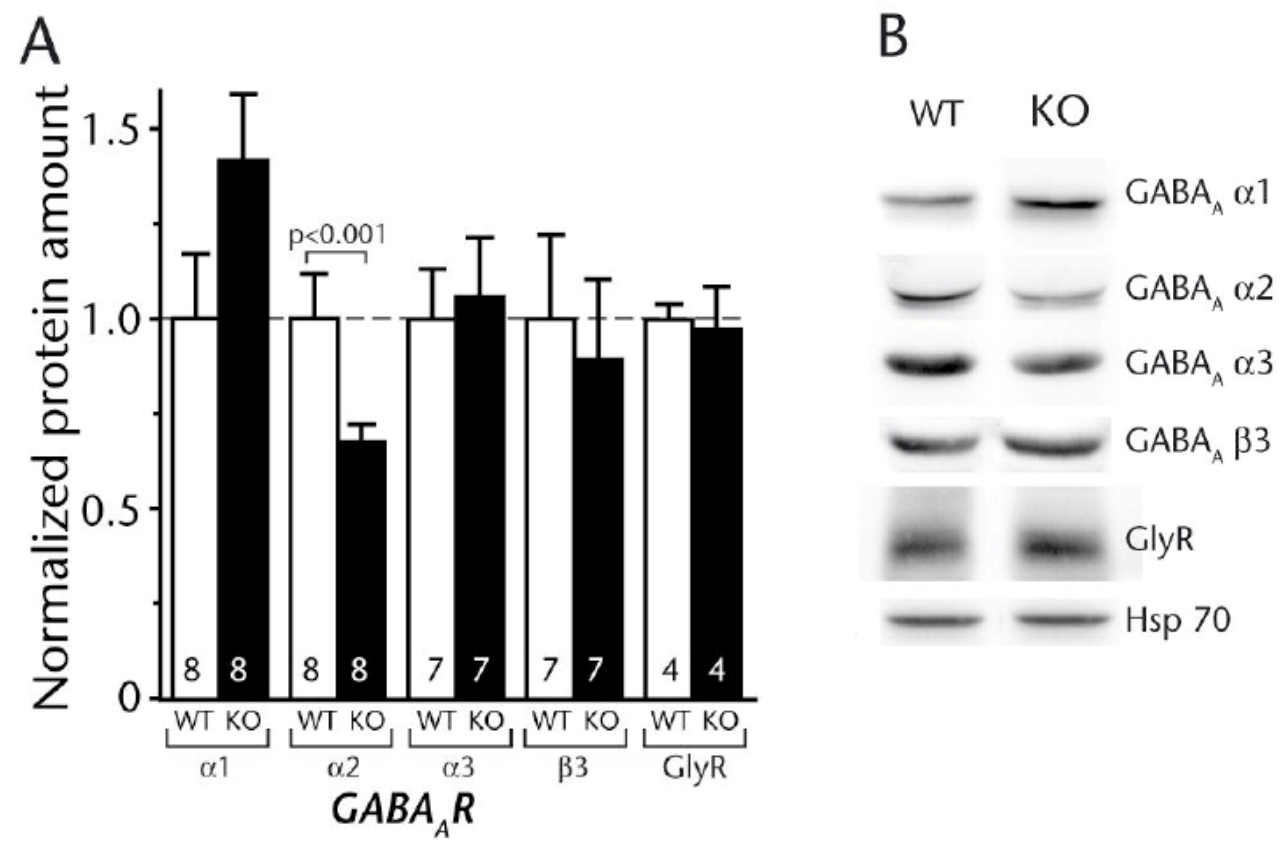

Figure 3.18. Protein levels of postsynaptic $\mathrm{GABA}_{\mathrm{A}}$ receptor subunits are changed in early postnatal MeCP2 knockout mice. A) Quantification of protein levels of $\mathrm{GABA}_{\mathrm{A}}$ and glycine receptor subunits in brainstem lysates of littermate control (white bars, WT) and MeCP2 deficient mice (black bars, KO) at postnatal days P7. B) Representative immunoblots of $\mathrm{GABA}_{\mathrm{A}} \mathrm{R} \alpha 1, \alpha 2, \alpha 3$, and $\beta 3$ subunits, glycine receptor GlyR, and heat shock protein Hsp70 as input control.

The $\mathrm{GABA}_{A} \alpha 3$ and $\mathrm{GABA}_{A} \beta 3$ subunits showed relatively similar expression levels between the $\mathrm{KO}$ and WT mouse brainstem. In contrast the $\mathrm{GABA}_{\mathrm{A}} \alpha 2$-subunit is expressed at higher levels at WT compared to KO mice. Exactly the opposite becomes visible, in case of the $\mathrm{GABA}_{\mathrm{A}} \alpha 1$ subunit, which shows an increase of the expressed levels of the $\alpha 1$-subunit in $\mathrm{KO}$ mice compared to the lower levels of the protein in WT. 


\section{DISCUSSION}

\subsection{Developmental changes of the GABAergic system}

In the central nervous system, $\gamma$-aminobutyric acid (GABA) is known to act as an inhibitory neurotransmitter, via ligand-gated $\mathrm{GABA}_{\mathrm{A}}$ receptor channels and $\mathrm{G}$ protein-coupled $\mathrm{GABA}_{\mathrm{B}}$ receptors. Although GABA is best known for his inhibitory effect, more and more data suggest that GABA may be 'inhibitory' to mature neurons, but 'excitatory' to immature neurons which indicates an age-dependent regulation of his function. The majority of available data is from studies of $\mathrm{GABA}_{\mathrm{A}}$ receptors (BenAri, Cherubini et al. 1989; Michelson and Wong 1991; Owens, Boyce et al. 1996; Rivera, Voipio et al. 1999; Ruano, Araujo et al. 2000; Ganguly, Schinder et al. 2001; Hubner, Stein et al. 2001; Ben-Ari 2002; Owens and Kriegstein 2002; Leitch, Coaker et al. 2005), while less is known about the developmental inhibitory-excitatory switching in the function of the $\mathrm{GABA}_{\mathrm{B}}$ receptors (Harrison, Lange et al. 1988; Gaiarsa, Tseeb et al. 1995; Zhang, Elsen et al. 1999).

In this study, our main interest is the developmental changes of GABA receptor signaling in mice. The brain area of our interest is the brainstem and in some experiments the pre-Bötzinger complex (PBC), a brainstem region. The PBC has been postulated as the centre of respiratory rhythmogenesis (Smith, Ellenberger et al. 1991; Funk and Feldman 1995; Ramirez and Richter 1996; Rekling and Feldman 1998) and it is one region in which the $\mathrm{GABA}_{\mathrm{B}}$ mediated signaling shows postnatal developmental changes (Zhang, Elsen et al. 1999). In addition, this brain area, in combination with Rett syndrome, a neurodevelopmental disorder where breathing abnormalities such as hyperventilation and apnea appear and where an indication of an age related depression of the inhibitory activity exist, offers an advantageous model for the investigation of the developmental changes in the $\mathrm{GABA}_{\mathrm{A}}$ receptor function.

In this study we investigated MeCP2 knockout mice, an irregular switching from excitation to inhibition. Signaling and subunit expression of the $\mathrm{GABA}_{\mathrm{A}}$ receptors were examined in the PBC of mice lacking the transcriptional repressor MeCP2 and compared to normal mice, of the same age (P7). 
In case of the developmental switch caused by the $\mathrm{GABA}_{\mathrm{B}}$ receptors, almost nothing is known. In this study we investigated which factors could control or influence the developmental shift in the function of the $\mathrm{GABA}_{\mathrm{B}}$ receptor during brainstem maturation of newborn and adult mice.

\subsubsection{Differential GABA $_{\mathrm{B}}$-receptor-mediated modulation during brainstem maturation}

Like all other GPCR (see chapter 1.2), GABA $\mathrm{B}_{\mathrm{B}}$ receptor signaling diversity may arise from numerous factors, among them the expression of different $\mathrm{GABA}_{\mathrm{B}}$-receptor subtypes and the expression of different $G$ protein subtypes which are able to interact with the receptor.

In the present study we investigated two factors that might be responsible for the developmental alteration in the function of the $\mathrm{GABA}_{B}$ receptors: First, we analysed the existence of a distinct $\mathrm{GABA}_{\mathrm{B}} \mathrm{R} 2$ subtype or any additional change in the molecular structure of this subunit which contains the $G$ protein coupling site(s). Although, various isoforms of the $\mathrm{GABA}_{\mathrm{B}} \mathrm{R} 1$ and $\mathrm{GABA}_{\mathrm{B}} \mathrm{R} 2$ have been described (Kaupmann, Huggel et al. 1997; Jones, Borowsky et al. 1998; Kaupmann, Malitschek et al. 1998; Pfaff, Malitschek et al. 1999; Calver, Medhurst et al. 2000; Clark, Mezey et al. 2000), only the expression of the $G_{A B A} R 1$ splice variants, $\mathrm{GABA}_{\mathrm{B}} \mathrm{R} 1 \mathrm{a}$ and $\mathrm{GABA}_{\mathrm{B}} \mathrm{R} 1 \mathrm{~b}$, is proven. Thus, we scanned for the expression of different $\mathrm{GABA}_{\mathrm{B}} \mathrm{R} 2$ variants during brain maturation. Investigation of the $\mathrm{G}$ protein coupling sites of the $\mathrm{GABA}_{\mathrm{B} 2}$ receptor at different ages revealed no diversity in the expression of the receptor subunit between the mature and immature NMRI mouse brainstems. We demonstrate that at protein level the G protein coupling sites of the $\mathrm{GABA}_{\mathrm{B} 2}$ receptor in brainstem between the newborn and adult mouse are identical.

Second, we considered an alternate explanation for the developmental changes of $\mathrm{GABA}_{\mathrm{B}}$ receptor signaling is that the functional coupling between $\mathrm{GABA}_{\mathrm{B}}$ receptors to $\mathrm{G}$ proteins alters during development. Nowadays, it is general accepted that the downstream effects of $\mathrm{GABA}_{\mathrm{B}}$ receptor activation is mediated via the activation of $\mathrm{G}$ proteins, and predominantly by $\mathrm{G}$ proteins of the $\mathrm{G} \alpha_{\mathrm{i} / \mathrm{o}}$ class (Asano and Ogasawara 
1986; Morishita, Kato et al. 1990). So far, it is not known whether the GABA receptors are also able to interact with other $\mathrm{G}$ proteins, such as $\mathrm{G} \alpha_{\mathrm{s}}, \mathrm{G} \alpha_{\mathrm{q}}, \mathrm{G} \alpha_{11}$ etc., and activate other signaling pathway. To investigate activation and selective binding of $\mathrm{GABA}_{\mathrm{B}}$ receptors to different $\mathrm{G}$ alpha proteins in mouse brainstem at different ages we used $\left[{ }^{35} \mathrm{~S}\right]-\mathrm{GTP} \gamma \mathrm{S}$ - and Eu-GTP- binding assays in combination with immunoprecipitation. The results (see chapter 3.3) reveal that the $\mathrm{GABA}_{\mathrm{B}}$ agonist baclofen stimulates GTP $\gamma \mathrm{S}$ - and Eu-GTP-binding in the case of Gai/o at both ages (P0 and adult) and this response is blocked by the $\mathrm{GABA}_{\mathrm{B}}$ receptor antagonist CGP 55845A. In contrast neither baclofen-stimulated GTP $\gamma \mathrm{S}$ - nor Eu-GTP-binding was observed in adult brainstem tissue in case of the $\mathrm{G} \alpha_{\mathrm{s}}$ under similar incubation conditions. However, there was an unexpectedly dramatic increase of the immunoprecipitated $\mathrm{G} \alpha_{\mathrm{S}}$ in newborn brainstem homogenates. Stimulation of brainstem $\mathrm{GABA}_{\mathrm{B}}$ receptors resulted no GTP-binding to the $\mathrm{G \alpha}_{\mathrm{i} 3}, \mathrm{G \alpha i}_{12}$ and $\mathrm{G} \alpha_{13}$ proteins at both ages. The amount of the immunoprecipitated $\mathrm{G}_{\mathrm{q} / 11}$ after $\mathrm{GABA}_{\mathrm{B}}$ receptors activation in newborn and adult mice was not indicative. Although the results of the GTP $\gamma \mathrm{S}$-binding assay were more intense compared to the new Eu-GTPbinding assay, we developed the Eu-GTP-binding assay, in combination with immunoprecipitation, to increase the number of experiments and to avoid working with radioactivity.

Taken together, these results indicate that in addition to the expected interaction of the $\mathrm{GABA}_{\mathrm{B}}$ receptors with the $\mathrm{G \alpha}_{\mathrm{i} / \mathrm{o}}$ proteins in adults we were able to demonstrate that $\mathrm{GABA}_{\mathrm{B}}$ receptors interact with the $\mathrm{G} \alpha_{\mathrm{i} / \mathrm{o}}$ proteins in newborn mice brainstem. The most distinct finding was the observation that activated $\mathrm{GABA}_{\mathrm{B}}$ receptors couple to $\mathrm{G} \alpha_{\mathrm{s}}$ proteins but only in the immature brainstem. In adult mouse brainstem this interaction was non-existant. This developmental regulated interaction between the activated $G A B A_{B} R$ and the $G \alpha_{s}$ proteins, lead us to investigate the developmental expression of the $\mathrm{G}$ alpha s protein subtypes.

\subsubsection{Diversity of $G A B A_{B}$ receptor signaling through $G$ protein variability}

The heterotrimeric $G$ proteins composed of $\alpha, \beta$, and $\gamma$ subunits with their subunit combinations and their multiple splice variants control diverse signal transduction pathways. The expression of the G protein subtypes in the developing brain is age- 
dependent and characteristic for a specific brain region. Qualitative and quantitative analysis of the $\mathrm{G} \alpha$ protein subtypes in mouse brainstem revealed diverse expression patterns for the $\mathrm{G} \alpha$ protein subtypes of our interest. The expression levels of the $G \alpha_{\mathrm{i} / \mathrm{o}}$ are equal in all three investigated brain areas (cortex, cerebellum and brainstem) at both developmental stages (newborn and adult). The same result was revealed from the analysis of the $\mathrm{G} \alpha_{\mathrm{q} / 11}$. The examination of the $\mathrm{G} \alpha_{\mathrm{s}}$ proteins was more complicate because of the numerous isoforms produced by the rather complex genomic locus of GNAS. Western blot analysis with $\mathrm{G \alpha}_{\mathrm{s}}$ antibody showed up six bands with a developmental regulated expressions pattern. Two of them, clearly identified as the short and long isoforms of the $\mathrm{G} \alpha_{\mathrm{s}}$, showed strong expression levels in the immature brainstem that were decreased during maturation. On the other side, the two isoforms Gs1 and Gs2, which are almost missing in the newborn give a strong signal in adult brainstem, and represent two XLas isoforms of the $\mathrm{G} \alpha_{\mathrm{s}}$. The other two variants Gs5 and Gs6, was not possible to be distinguished. Thus, although the complexity of the GNAS locus and the continuously new data did not permit us to identify all six $G \alpha_{\text {s }}$ isoforms, we could distinguish between the two Gas (short and long) which show a decreas in expression, and the two extra long $G \alpha_{\mathrm{s}}$ which show an increase in expression during mouse brainstem maturation. Although it is known, like in the case of $\beta 2$-adrenoreceptor, that the $G \alpha_{\mathrm{s}}$ short and long variants, which differ in only 15 amino acids, have different consequences for the functional properties of a G-proteincoupled receptor (Seifert, Wenzel-Seifert et al. 1998), it is not known how the interaction between the XLas isoforms and the $\mathrm{GABA}_{\mathrm{B}}$ receptor influences the function of the receptor. The paternal expressed XLas contains all structural domains of $\mathrm{G} \alpha_{\mathrm{s}}$, except the long amino-terminal extension encoded within its specific first exon. Even though in vitro studies have shown that XLas forms a heterotrimer with $\beta \gamma$ subunits, binds GTP and mediates receptor-stimulated cAMP production, the biological role(s) of XLas within the cell remains obscure. There are also some conflict reports, based on the ability of XLas to activate a receptor. Moreover, recent findings indicate that the GNAS products are capable of modulating the activity/expression of each other, something that makes more difficult to predict which influence will have these interactions in the $\mathrm{GABA}_{\mathrm{B}}$ receptors signaling. For example, it is known that XLas and $G \alpha_{\mathrm{s}}$ exert antagonistic functions and that the maternal expressed Nesp enhances the expression of XLas and represses the expression of $\mathrm{Ga}_{\mathrm{s}}$. Even the paternal expressed protein called Alex, which is a 
structurally unrelated protein to the G proteins, and is also encoded in the GNAS locus, has the ability to interact with XLas, and inhibits its adenylyl cyclasestimulating function.

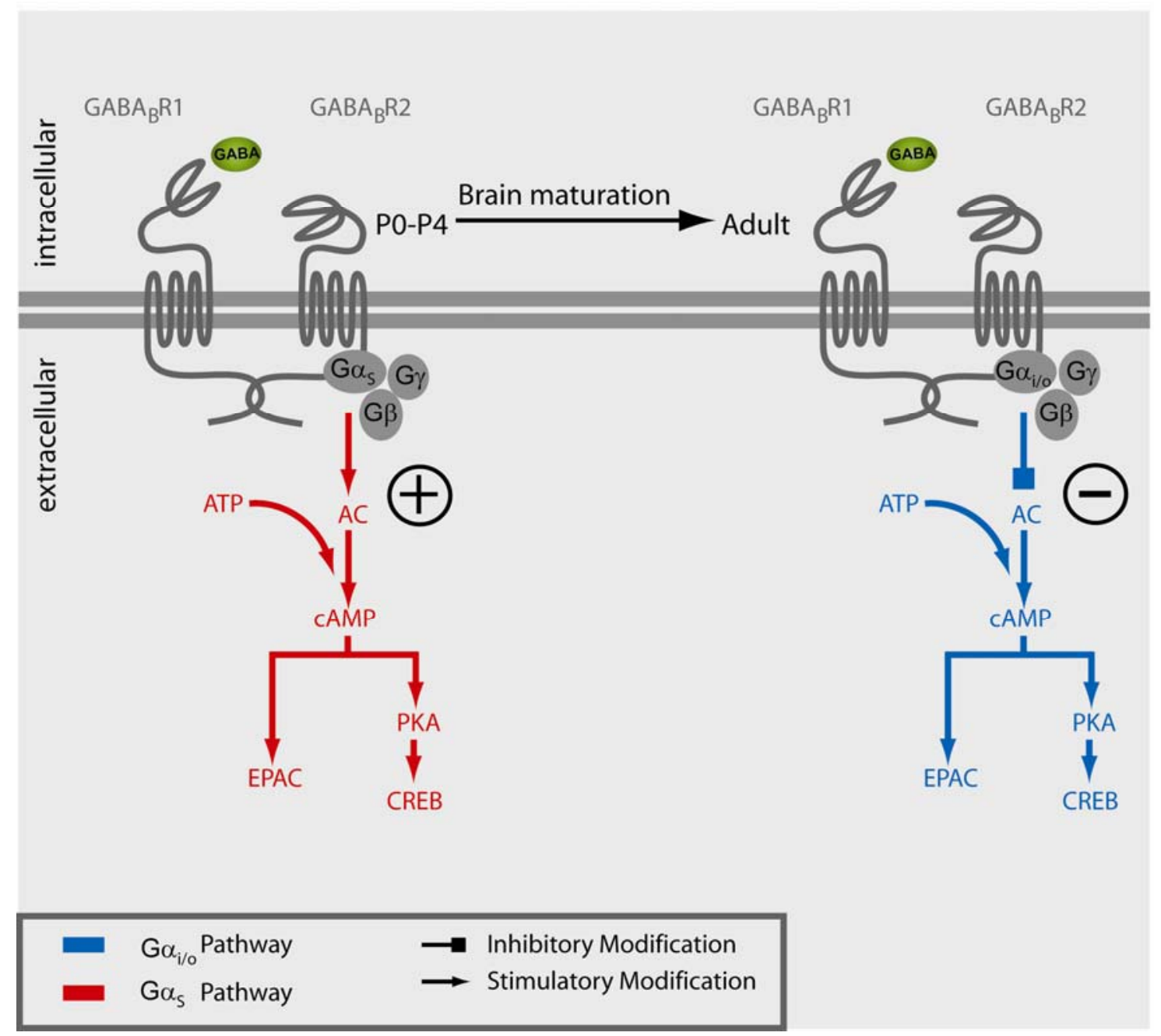

Figure 4.1. Schematic representation of the activation of different signaling pathways through the $\mathrm{GABA}_{\mathrm{B}}$ receptors in immature and adult mouse brainstem.

The brainstem cAMP measurement at newborn and adult mice after activation with baclofen, revealed no significant values that could possibly be explained through the antagonistic effect of the GNAS locus products (e.g. Nesp, Alex, XLN1), or the antagonistic function of the $\mathrm{G} \alpha$ and $\mathrm{G} \beta \gamma$ subunits, or even through cross-talk with other pathways.

We can only speculate on the $\mathrm{GABA}_{\mathrm{B}}$ receptor-mediated signaling through the GNAS locus products. One explanation could be that the $\mathrm{GABA}_{\mathrm{B}} \mathrm{R}-\mathrm{G} \alpha_{\mathrm{s}}$ (short and long) 
interaction in the immature brainstem is hindered in the adult brainstems through a sterical interference or general an antagonistic function of the XLas variants (or other by other proteins expressed in the GNAS locus).

The distinctive characteristic of $\mathrm{GABA}_{\mathrm{B}} \mathrm{R}$, the formation of a heterodimers, could influence additional receptor signaling. $\mathrm{GABA}_{\mathrm{B} 1}$ with the two isoforms $\mathrm{GABA}_{\mathrm{B} 1 \mathrm{a}}$ and $\mathrm{GABA}_{\mathrm{B} 1 \mathrm{~b}}$ which contain the ligand binding site and $\mathrm{GABA}_{\mathrm{B}} \mathrm{R} 2$ with the $\mathrm{G}$ protein coupling site(s), regulate the function of the receptor based on the organism, the age, the brain region, the microdomain organisation and the receptor composition. Although it is generally accepted that coexpression of the two $\mathrm{GABA}_{B}$ receptors subunits $\left(\mathrm{GABA}_{B} \mathrm{R} 1\right.$ and $\left.\mathrm{GABA}_{B} \mathrm{R} 2\right)$ is required for a fully functional receptor, thus $\mathrm{GABA}_{\mathrm{B}} \mathrm{R} 2$ is necessary for the $\mathrm{GABA}_{\mathrm{B}} \mathrm{R} 1$ transportation, there is evidence that also $\mathrm{GABA}_{\mathrm{B}} \mathrm{R} 1$ (1a and $1 \mathrm{~b}$ ) and $\mathrm{GABA}_{\mathrm{B}} \mathrm{R} 2$ alone are able to couple to $\mathrm{K}^{+}$channels or adenylyl cyclase, although at low efficiency (Kaupmann, Huggel et al. 1997; Kaupmann, Schuler et al. 1998; Kuner, Kohr et al. 1999; Urwyler, Mosbacher et al. 2001). Thus, in our cloning experiments $\left(G_{A B} A_{B} R 1 a\right.$ and $G_{A B} A_{B} R 2$ expression in HEK 293 cells) because of the weak signal observed in the cells and the GABA $R 2$ expresion in the intracellular areas of the cell, we can conclude it concerns monomeric $\mathrm{GABA}_{\mathrm{B}} \mathrm{R} 1 \mathrm{a}$ receptors.

Additionally, although the $\mathrm{GABA}_{\mathrm{B} 1}$ intracellular loops are not necessary for $\mathrm{G}$ protein coupling they may be involved in signaling pathways not involving $G$ proteins or in the regulation of subcellular $\mathrm{GABA}_{\mathrm{B}}$ receptor localization. For example $\mathrm{GABA}_{\mathrm{B} 1}$ subtypes interact directly with CREB2/ATF4, USF, 14-3-3 and through subtypeselective interacting proteins for the $\mathrm{GABA}_{\mathrm{B} 1 \mathrm{a}}$ and $\mathrm{GABA}_{\mathrm{B} 2}$ (see chapter 1.6.3.1). These associated proteins are able to regulate subtype-specific expression of the $\mathrm{GABA}_{\mathrm{B} 1 \mathrm{a} \& \mathrm{~b}}$ subunits, receptor heterodimerization and cross-talks between different systems, such as Tamalin and NSF.

The distinct subcellular distribution and behaviour of the $\mathrm{GABA}_{\mathrm{B} 1}$ subunits with $\mathrm{GABA}_{\mathrm{B} 1 \mathrm{a}}$ dominant in neonatal brain and $\mathrm{GABA}_{\mathrm{B} 1 \mathrm{~b}}$ predominant in adults could play an additional role to the $\mathrm{GABA}_{\mathrm{B}}$ receptor mediated signaling diversity.

Another layer of complexity arises from the ability of the GPCRs to activate simultaneously multiple $G$ protein pools. Dual coupling to $G \alpha_{\mathrm{s}}$ and $G \alpha_{\mathrm{i} / \mathrm{o}}$ has been reported, as in the case of the $\beta 2$-adrenoceptor (Daaka, Luttrell et al. 1997), where the receptor phosphorylation, via PKA, controls the switching from the $G \alpha_{\mathrm{s}}$ to the $G \alpha_{\mathrm{i} / \mathrm{o}}$ 
pathway. In some cases, a single receptor has been found to simultaneously activate members of three or even four unrelated classes of $\mathrm{G}$ protein $\left(\mathrm{G} \alpha_{\mathrm{s}}, \mathrm{G} \alpha_{\mathrm{i} / \mathrm{O}}, \mathrm{G} \alpha_{\mathrm{q} / 11}\right.$, and $\mathrm{G}_{12}$ ) (Laugwitz, Allgeier et al. 1996). The interaction of these receptors with multiple $\mathrm{G}$ protein classes produces additional interference between the products of each pathway, through the generation of different $G \alpha$ and $G \beta \gamma$ subunits.

Thus, although we do not know if the interaction of the $\mathrm{GABA}_{\mathrm{B}}$ receptors in the immature brainstem to the $\mathrm{G} \alpha_{\mathrm{s}}$ and $\mathrm{G} \alpha_{\mathrm{i} / \mathrm{o}}$ proteins is a simultaneous coupling of the two $G$ proteins or if there is a factor that controls a $G \alpha_{s}-G \alpha_{i / o}$ switching, we can conclude that in general the $\mathrm{GABA}_{\mathrm{B}}$-receptor binding to $\mathrm{G} \alpha_{\mathrm{s}}$ proteins will initiates a new set of signaling events.

These observations together lead us to the conclusion that the interaction of $\mathrm{GABA}_{\mathrm{B}}$ receptor to the $G \alpha_{\mathrm{s}}$ and $\mathrm{G} \alpha_{\mathrm{i} / \mathrm{o}}$ proteins in the immature brainstem and only to the $\mathrm{G} \alpha_{\mathrm{i} / \mathrm{o}}$ proteins in the mature brainstem, are probably regulated by additional factors e.g. the $\mathrm{GABA}_{\mathrm{B}} \mathrm{R} 1$ subunit, the way of interaction with the $\mathrm{G}$ proteins (simultaneously or switching) and via the organization of all these proteins (e.g. receptors, G proteins, associated proteins) within specialized microdomains.

\subsection{Changes in the $\mathrm{GABA}_{A}$ receptor signaling in the developing mouse brainstem in the model of Rett syndrome}

The switching of the $\mathrm{GABA}_{\mathrm{A}}$ receptor from an excitatory action in immature CNS neurons to the well-established inhibitory action of the adult neurons was recognized in some of the very early studies (Eccles, Schmidt et al. 1963; Obata, Oide et al. 1978).

Since then, the depolarization induced by GABAergic neurotransmission has been observed in immature neural systems, such as the spinal cord (Wu, Ziskind-Conhaim et al. 1992; Reichling, Kyrozis et al. 1994; Nishimaru, Iizuka et al. 1996; Gao and van den Pol 2001), brainstem (Ritter and Zhang 2000; Marchetti, Pagnotta et al. 2002), retina (Huang and Redburn 1996), olfactory bulb (Serafini, Valeyev et al. 1995), hippocampus (Ben-Ari, Cherubini et al. 1989; Cherubini, Rovira et al. 1990; Michelson and Wong 1991; Cherubini, Martina et al. 1998; Ruano, Araujo et al. 
2000; Ben-Ari 2002), hypothalamus (Chen, Trombley et al. 1996; Gao and van den Pol 2001), and the neocortex (Luhmann and Prince 1991; Owens, Boyce et al. 1996). Activation of $\mathrm{GABA}_{\mathrm{A}}$ receptors during embryonic life produces depolarization because of a high concentration of intracellular chloride ions. The intracellular accumulation of chloride seems to be generated by a delay in the expression of the chloride exporter KCC2 and through accumulate $\mathrm{Cl}^{-}$, probably through the $\mathrm{Na}^{+}-\mathrm{K}^{+}-\mathrm{Cl}^{-}$ cotransporter (NKCC1) (Vardi, Zhang et al. 2000). The inhibitory action of the $\mathrm{GABA}_{\mathrm{A}}$ receptors in mature neurons is associated with a hyperpolarisation (Rivera, Voipio et al. 1999). Activation of $\mathrm{GABA}_{\mathrm{A}}$ receptors leads to an influx of chloride ions but the intracellular concentration of $\mathrm{Cl}^{-}$decreases with development, probably through the upregulation of a $\mathrm{Cl}^{-}$extrusion mechanism; the $\mathrm{K}^{+}-\mathrm{Cl}^{-}$cotransporter (KCC2) (Rivera, Voipio et al. 1999; Payne, Rivera et al. 2003).

The depolarizing action of $\mathrm{GABA}_{\mathrm{A}}$ receptors during early development induces an increase in intracellular calcium (Lin, Takahashi et al. 1994; Ben-Ari 2002), in contrast to the decreased intracellular calcium levels in mature neurons. This $\mathrm{Ca}^{2+}$ enhancment in immature neurons may control several developmental phenomena, including synapse formation (Ben-Ari, Khazipov et al. 1997; Cherubini, Martina et al. 1998; Owens and Kriegstein 2002), rate regulation of neurone outgrowth (Maric, Liu et al. 2001), promotion of morphological differentiation (Ben-Ari, Tseeb et al. 1994; Marty, Berninger et al. 1996) and/or neuronal migration (Barker, Behar et al. 1998).

Although, the exact mechanism underlying this shift remains unknown, it has been suggested that the transition from depolarization to hyperpolarisation is associated with $\mathrm{GABA}_{A}$ receptor subunit switching. Developmental changes in the subunit composition modulate the function of the $\mathrm{GABA}_{\mathrm{A}}$ receptor (Takayama and Inoue 2004; Lujan, Shigemoto et al. 2005). It has been postulated that the subunit composition with alpha 2 (or alpha 3), which are mainly expressed in immature brain areas, would contribute to the depolarizing $\mathrm{GABA}_{\mathrm{A}}$ effect (Hornung and Fritschy 1996), whereas the expression of the alpha1-subunit which is low at birth increase dramatically during brain maturation is involved in synaptic inhibition (Fritschy, Paysan et al. 1994). This $\mathrm{GABA}_{\mathrm{A}} \mathrm{R}$ subunit switch is conserved across species.

There is only a short time window where many individual neurons show a coexistence of both $\alpha 1$ and $\alpha 2$, which indicates that the alpha 1-subunit gradually replace receptors containing the alpha 2-subunit (MacLennan, Brecha et al. 1991; Fritschy, Paysan et al. 1994; Hornung and Fritschy 1996; Lopez-Tellez, Vela et al. 2004). The time line of 
switch from depolarizing to hyperpolarizing GABA transmission and the timing of the replacement of $\mathrm{GABA}_{\mathrm{A}}$ receptor alpha 2-subunits by alpha1-subunits take place, in the case of the rat PBC, simultaneously, during the first postnatal week. In addition, the observed increase of intracellular calcium from the $\mathrm{GABA}_{\mathrm{A}}$ receptor action in immature neurons disappears when the $\mathrm{GABA}_{\mathrm{A}}$ receptor alpha2-subunit is replaced by alpha1-subunit (Lin, Takahashi et al. 1994).

In this study we investigated the imbalance between excitation and inhibition in MeCP2 knockout mice, a model system that allowed us to examine the Rett syndrome. $\mathrm{MeCP} 2$ is a protein which binds to DNA and regulates transcriptional repression. It is widely and increasingly expressed during development (Kishi and Macklis 2004). Thus, loss of MeCP2 function leads to improper gene expression programs.

Although many studies suggest that this synaptic imbalance (Dani, Chang et al. 2005; Moretti, Levenson et al. 2006) may cause the Mecp2 observed abnormalities, it is still unknown which transmitter and receptors are predominantly involved.

Electrophysiological experiments in mouse PBC at the age of P7 indicate that mecp2 KO mice show, compared to the WT mice, a marked depression of inhibitory activity which is regulated by the $\mathrm{GABA}_{\mathrm{A}}$ receptor (in press L. Medrihan et al. 2007). The investigated age of $\mathrm{P} 7$ is a critical period where the symptoms of the syndromes are not manifested.

We investigated the expression levels of the $\mathrm{GABA}_{\mathrm{A}}$ subunits and glycin of the mecp2 in the KO mice brainstem at the age of $\mathrm{P} 7$ in comparison to the expression levels of the $\mathrm{GABA}_{\mathrm{A}}$ receptor subunits at the same age in normal mice brainstem. The results of the experiments demonstrate no difference in the expression levels of glycin, an increase of the $\alpha 1$-subunit and a decrease of the $\alpha 2$-subunit in brainstem of the mecp $2 \mathrm{KO}$ mice in comparison to the healthy mice. This expression pattern normally appears in further stages of brain maturation where the $\mathrm{GABA}_{\mathrm{A}}$ receptors contribute more to an inhibitory that to an excitatory tone. Collectively the data supports the view that the synaptic imbalance observed in the mouse model of Rett syndrome is related to an irregular time switching of the $\mathrm{GABA}_{\mathrm{A}}$ receptor alpha subunits. But it is still and open question as to whether the $\mathrm{GABA}_{\mathrm{A}}$ receptor's abnormal switching is the cause or the result of the syndrome. 


\section{SUMMARY AND CONCLUSIONS}

Although, in the adult central nervous system, GABA is known to act as an inhibitory neurotransmitter, recent studies have revealed that the role of the GABAergic system changes developmentally, so that in the immature CNS serves as an excitatory neurotransmitter. In this study, we examined factors that influence the developmental changes of the ionotropic $\mathrm{GABA}_{\mathrm{A}}$ and metabotropic $\mathrm{GABA}_{\mathrm{B}}$ receptor signaling in mouse brainstem.

We examined the signaling modulation of a GPCR receptor, the $\mathrm{GABA}_{\mathrm{B}}$ receptor, in the developing mouse brainstem as function of $\mathrm{GABA}_{\mathrm{B}}$ receptor subtype variants, binding properties of $\mathrm{GABA}_{\mathrm{B}}$ receptor to different $\mathrm{G}$ proteins, and $\mathrm{G}$ protein expression variability.

We demonstrated that the developmental alteration of the $\mathrm{GABA}_{\mathrm{B}}$ receptor signaling between neonatal and adult mouse brainstem is not associated with expression difference in the $G$ protein coupling sites of the $G_{A B A} R 2$. The investigation of the $\mathrm{GABA}_{\mathrm{B}}$ signaling pathways in newborn and adult mouse brainstem revealed that $\mathrm{GABA}_{\mathrm{B}}$ receptors couple to $\mathrm{G \alpha}_{\mathrm{i} / \mathrm{o}}$ proteins at both ages. Furthermore, we found that $\mathrm{GABA}_{\mathrm{B}}$ receptors interact also with $\mathrm{G} \alpha_{\mathrm{s}}$ proteins, and that this coupling disappears with further maturation. Additional experiments demonstrated equal amounts of whole cell $\mathrm{G} \alpha_{\mathrm{i} / \mathrm{o}}$ proteins between neonatal and adult mouse brainstem, whereas the $\mathrm{G} \alpha_{\mathrm{s}}$ variants showed an age-dependent alteration in their expression. Analysis of the $G \alpha_{s}$ variants showed a decrease in the expression of the $G \alpha_{\mathrm{s}}$ short and long variants during maturation of the brainstem whereas the XLas variants were almost absent in the immature brainstem. The complexity and variability of the $G \alpha_{\mathrm{s}}$ variants as well as their ability to modulate each other, makes it difficult to predict their influence to the $\mathrm{GABA}_{\mathrm{B}}$ receptor signaling.

In addition, we investigated the $\mathrm{GABA}_{\mathrm{A}}$ receptors in brainstem of $\mathrm{MeCP} 2$ knockout mice, a model system which allowed us to examine Rett syndrome. A neurodevelopmental disorder where the balance between excitation and inhibition, which exist in healthy brains and is essential for nearly all functions, is shifted. $\mathrm{GABA}_{\mathrm{A}}$ receptors are known to switch from an excitatory action in immature CNS neurons to an inhibitory action in the adult neurons. Although there is no direct 
evidence the developmental regulated shift in the function of the $\mathrm{GABA}_{\mathrm{A}}$ receptors is correlated with the switching of the alpha $\mathrm{GABA}_{\mathrm{A}}$ receptor subunits.

We demonstrated a time shifted switch in the expression of the $\mathrm{GABA}_{\mathrm{A}}$ alpha1 and alpha2 subunit in the rat pre-Botzinger complex (PBC) on postnatal day (P) 7 between the knockout and healthy mice, a critical period where the symptoms of the syndromes are not manifested. Brainstem analysis of knockout mice revealed decreased levels of $\mathrm{GABA}_{\mathrm{A}}$ alpha1 and increased levels of $\mathrm{GABA}_{\mathrm{A}}$ alpha 2 comparing to normal mice of the same age (P7). The two subunits have an exceptional role in the regulation of the $\mathrm{GABA}_{\mathrm{A}}$ receptor, thus it is proposed that the $\mathrm{GABA}_{\mathrm{A}}$ alphal subunits which are mainly expressed in the mature brain, are involved in synaptic inhibition, whereas the $\mathrm{GABA}_{\mathrm{A}}$ alpha2 subunits which are mainly expressed in immature brain areas, contribute to the depolarizing $\mathrm{GABA}_{\mathrm{A}}$ effect. Our data from the $\mathrm{GABA}_{\mathrm{A}} \mathrm{R}$ subunits expression levels, agree with the observations from electrophysiological experiments (in press L. Medrihan et al. 2007) in mouse PBC at the age of P7, which indicate that mecp2 $\mathrm{KO}$ mice show, in comparison to the WT mice, a marked depression of inhibitory activity.

Collectively, our data supports the view that the synaptic imbalance observed in the mouse model of Rett syndrome is related to an irregular time switching of $\mathrm{GABA}_{\mathrm{A}}$ receptors alpha subunits. 


\section{REFERENCES}

Abramowitz, J., D. Grenet, et al. (2004). "XLalphas, the extra-long form of the alphasubunit of the Gs G protein, is significantly longer than suspected, and so is its companion Alex." Proc Natl Acad Sci U S A 101(22): 8366-71.

Amico, C., C. Marchetti, et al. (1995). "Pharmacological types of calcium channels and their modulation by baclofen in cerebellar granules." J Neurosci 15(4): 2839-48.

Amin, J. and D. S. Weiss (1996). "Insights into the activation mechanism of rho1 GABA receptors obtained by coexpression of wild type and activationimpaired subunits." Proc Biol Sci 263(1368): 273-82.

Amir, R. E., I. B. Van den Veyver, et al. (1999). "Rett syndrome is caused by mutations in X-linked MECP2, encoding methyl-CpG-binding protein 2." Nat Genet 23(2): 185-8.

Andrade, R., R. C. Malenka, et al. (1986). "A G protein couples serotonin and GABAB receptors to the same channels in hippocampus." Science 234(4781): 1261-5.

Armstrong, D. M., R. Sheffield, et al. (2003). "Plasticity of glutamate and GABAA receptors in the hippocampus of patients with Alzheimer's disease." Cell Mol Neurobiol 23(4-5): 491-505.

Asano, T. and N. Ogasawara (1986). "Uncoupling of gamma-aminobutyric acid B receptors from GTP-binding proteins by N-ethylmaleimide: effect of $\mathrm{N}$ ethylmaleimide on purified GTP-binding proteins." Mol Pharmacol 29(3): 244-9.

Asano, T., M. Ui, et al. (1985). "Prevention of the agonist binding to gammaaminobutyric acid B receptors by guanine nucleotides and islet-activating protein, pertussis toxin, in bovine cerebral cortex. Possible coupling of the toxin-sensitive GTP-binding proteins to receptors." J Biol Chem 260(23): 12653-8.

Awapara, J., A. J. Landua, et al. (1950). "Free gamma-aminobutyric acid in brain." J Biol Chem 187(1): 35-9.

Balasubramanian, S., J. A. Teissere, et al. (2004). "Hetero-oligomerization between GABAA and GABAB receptors regulates GABAB receptor trafficking." Biol Chem 279(18): 18840-50.

Baldwin, J. M. (1993). "The probable arrangement of the helices in G protein-coupled receptors." Embo J 12(4): 1693-703. 
Balsinde, J., M. V. Winstead, et al. (2002). "Phospholipase A(2) regulation of arachidonic acid mobilization." FEBS Lett 531(1): 2-6.

Barker, J. L., T. Behar, et al. (1998). "GABAergic cells and signals in CNS development." Perspect Dev Neurobiol 5(2-3): 305-22.

Bastepe, M., Y. Gunes, et al. (2002). "Receptor-mediated adenylyl cyclase activation through XLalpha(s), the extra-large variant of the stimulatory G protein alphasubunit." Mol Endocrinol 16(8): 1912-9.

Baumann, S. W., R. Baur, et al. (2001). "Subunit arrangement of gammaaminobutyric acid type A receptors." J Biol Chem 276(39): 36275-80.

Belhage, B., G. H. Hansen, et al. (1998). "Effects of gamma-aminobutyric acid (GABA) on synaptogenesis and synaptic function." Perspect Dev Neurobiol 5(2-3): 235-46.

Ben-Ari, Y. (2002). "Excitatory actions of gaba during development: the nature of the nurture." Nat Rev Neurosci 3(9): 728-39.

Ben-Ari, Y., E. Cherubini, et al. (1989). "Giant synaptic potentials in immature rat CA3 hippocampal neurones." J Physiol 416: 303-25.

Ben-Ari, Y., R. Khazipov, et al. (1997). "GABAA, NMDA and AMPA receptors: a developmentally regulated 'menage a trois'." Trends Neurosci 20(11): 523-9.

Ben-Ari, Y., V. Tseeb, et al. (1994). "gamma-Aminobutyric acid (GABA): a fast excitatory transmitter which may regulate the development of hippocampal neurones in early postnatal life." Prog Brain Res 102: 261-73.

Benke, D., J. M. Fritschy, et al. (1994). "Distribution, prevalence, and drug binding profile of gamma-aminobutyric acid type A receptor subtypes differing in the beta-subunit variant." J Biol Chem 269(43): 27100-7.

Benke, D., M. Honer, et al. (1999). "gamma-aminobutyric acid type B receptor splice variant proteins GBR1a and GBR1b are both associated with GBR2 in situ and display differential regional and subcellular distribution." J Biol Chem 274(38): 27323-30.

Bettler, B., K. Kaupmann, et al. (1998). "GABAB receptors: drugs meet clones." Curr Opin Neurobiol 8(3): 345-50.

Bettler, B., K. Kaupmann, et al. (2004). "Molecular structure and physiological functions of GABA(B) receptors." Physiol Rev 84(3): 835-67.

Bettler, B. and J. Y. Tiao (2006). "Molecular diversity, trafficking and subcellular localization of GABAB receptors." Pharmacol Ther 110(3): 533-43. 
Bianchi, M. S., V. A. Lux-Lantos, et al. (2005). "Expression of gamma-aminobutyric acid B receptor subunits in hypothalamus of male and female developing rats." Brain Res Dev Brain Res 160(2): 124-9.

Billinton, A., N. Upton, et al. (1999). "GABA(B) receptor isoforms GBR1a and GBR1b, appear to be associated with pre- and post-synaptic elements respectively in rat and human cerebellum." Br J Pharmacol 126(6): 1387-92.

Bischoff, S., S. Leonhard, et al. (1999). "Spatial distribution of GABA(B)R1 receptor mRNA and binding sites in the rat brain." J Comp Neurol 412(1): 1-16.

Blaxter, T. J., P. L. Carlen, et al. (1986). "gamma-Aminobutyric acid hyperpolarizes rat hippocampal pyramidal cells through a calcium-dependent potassium conductance." J Physiol 373: 181-94.

Blein, S., R. Ginham, et al. (2004). "Structural analysis of the complement control protein $(\mathrm{CCP})$ modules of GABA(B) receptor 1a: only one of the two CCP modules is compactly folded." J Biol Chem 279(46): 48292-306.

Blue, M. E., S. Naidu, et al. (1999). "Altered development of glutamate and GABA receptors in the basal ganglia of girls with Rett syndrome." Exp Neurol 156(2): 345-52.

Blue, M. E., S. Naidu, et al. (1999). "Development of amino acid receptors in frontal cortex from girls with Rett syndrome." Ann Neurol 45(4): 541-5.

Bockaert, J., L. Fagni, et al. (2004). "GPCR interacting proteins (GIP)." Ther 103(3): 203-21.

Bockaert, J. and J. P. Pin (1999). "Molecular tinkering of G protein-coupled receptors: an evolutionary success." Embo J 18(7): 1723-9.

Bolotina, V. M., S. Najibi, et al. (1994). "Nitric oxide directly activates calciumdependent potassium channels in vascular smooth muscle." Nature 368(6474): 850-3.

Bonanno, G. and M. Raiteri (1993). "Multiple GABAB receptors." Trends Pharmacol Sci 14(7): 259-61.

Bormann, J. (2000). "The 'ABC' of GABA receptors." Trends Pharmacol Sci 21(1): $16-9$.

Bormann, J. and A. Feigenspan (1995). "GABAC receptors." Trends Neurosci 18(12): 515-9.

Bos, J. L., J. de Rooij, et al. (2001). "Rap1 signalling: adhering to new models." Nat Rev Mol Cell Biol 2(5): 369-77. 
Bosman, L. W., T. W. Rosahl, et al. (2002). "Neonatal development of the rat visual cortex: synaptic function of GABAA receptor alpha subunits." J Physiol 545(Pt 1): 169-81.

Boue-Grabot, E., M. Roudbaraki, et al. (1998). "Expression of GABA receptor rho subunits in rat brain." J Neurochem 70(3): 899-907.

Bourne, H. R., D. A. Sanders, et al. (1991). "The GTPase superfamily: conserved structure and molecular mechanism." Nature 349(6305): 117-27.

Bowery, N. G. (1993). "GABAB receptor pharmacology." Annu Rev Pharmacol Toxicol 33: 109-47.

Bowery, N. G., B. Bettler, et al. (2002). "International Union of Pharmacology. XXXIII. Mammalian gamma-aminobutyric acid(B) receptors: structure and function." Pharmacol Rev 54(2): 247-64.

Bowery, N. G. and S. J. Enna (2000). "gamma-aminobutyric acid(B) receptors: first of the functional metabotropic heterodimers." J Pharmacol Exp Ther 292(1): $2-7$.

Bowery, N. G., D. R. Hill, et al. (1980). "(-)Baclofen decreases neurotransmitter release in the mammalian CNS by an action at a novel GABA receptor." Nature 283(5742): 92-4.

Brooks-Kayal, A. R., H. Jin, et al. (1998). "Developmental expression of GABA(A) receptor subunit mRNAs in individual hippocampal neurons in vitro and in vivo." J Neurochem 70(3): 1017-28.

Brown, E. M., G. Gamba, et al. (1993). "Cloning and characterization of an extracellular $\mathrm{Ca}(2+)$-sensing receptor from bovine parathyroid." Nature 366(6455): 575-80.

Brunig, I., E. Scotti, et al. (2002). "Intact sorting, targeting, and clustering of gammaaminobutyric acid A receptor subtypes in hippocampal neurons in vitro." $\underline{\mathrm{J}}$ Comp Neurol 443(1): 43-55.

Brussaard, A. B., K. S. Kits, et al. (1997). "Plasticity in fast synaptic inhibition of adult oxytocin neurons caused by switch in $\operatorname{GABA}(\mathrm{A})$ receptor subunit expression." Neuron 19(5): 1103-14.

Burch, R. M. (1989). "G protein regulation of phospholipase A2." Mol Neurobiol 3(3): 155-71.

Burstein, E. S., T. A. Spalding, et al. (1998). "The second intracellular loop of the m5 muscarinic receptor is the switch which enables G-protein coupling." J Biol Chem 273(38): 24322-7.

Cabrera-Vera, T. M., J. Vanhauwe, et al. (2003). "Insights into G protein structure, function, and regulation." Endocr Rev 24(6): 765-81. 
Calver, A. R., C. H. Davies, et al. (2002). "GABA(B) receptors: from monogamy to promiscuity." Neurosignals 11(6): 299-314.

Calver, A. R., A. D. Medhurst, et al. (2000). "The expression of GABA(B1) and $\mathrm{GABA}(\mathrm{B} 2)$ receptor subunits in the cNS differs from that in peripheral tissues." Neuroscience 100(1): 155-70.

Calver, A. R., M. J. Robbins, et al. (2001). "The C-terminal domains of the GABA(b) receptor subunits mediate intracellular trafficking but are not required for receptor signaling." J Neurosci 21(4): 1203-10.

Celentano, J. J., T. T. Gibbs, et al. (1988). "Ethanol potentiates GABA- and glycineinduced chloride currents in chick spinal cord neurons." Brain Res 455(2): 377-80.

Chebib, M. and G. A. Johnston (1999). "The 'ABC' of GABA receptors: a brief review." Clin Exp Pharmacol Physiol 26(11): 937-40.

Chen, G., P. Q. Trombley, et al. (1996). "Excitatory actions of GABA in developing rat hypothalamic neurones." J Physiol 494 (Pt 2): 451-64.

Cherubini, E., M. Martina, et al. (1998). "GABA excites immature CA3 pyramidal cells through bicuculline-sensitive and -insensitive chloride-dependent receptors." Perspect Dev Neurobiol 5(2-3): 289-304.

Cherubini, E., C. Rovira, et al. (1990). "GABA mediated excitation in immature rat CA3 hippocampal neurons." Int J Dev Neurosci 8(4): 481-90.

Chidiac, P., T. E. Hebert, et al. (1994). "Inverse agonist activity of beta-adrenergic antagonists." Mol Pharmacol 45(3): 490-9.

Clapham, D. E. and E. J. Neer (1997). "G protein beta gamma subunits." Annu Rev Pharmacol Toxicol 37: 167-203.

Clark, J. A., E. Mezey, et al. (2000). "Distribution of the GABA(B) receptor subunit gb2 in rat CNS." Brain Res 860(1-2): 41-52.

Coleman, M., J. Brubaker, et al. (1988). "Rett syndrome: a survey of North American patients." J Ment Defic Res 32 (Pt 2): 117-24.

Collinson, N., F. M. Kuenzi, et al. (2002). "Enhanced learning and memory and altered GABAergic synaptic transmission in mice lacking the alpha 5 subunit of the GABAA receptor." J Neurosci 22(13): 5572-80.

Costa, T. and A. Herz (1989). "Antagonists with negative intrinsic activity at delta opioid receptors coupled to GTP-binding proteins." Proc Natl Acad Sci U S A 86(19): 7321-5. 
Coughlin, S. R. (1994). "Expanding horizons for receptors coupled to G proteins: diversity and disease." Curr Opin Cell Biol 6(2): 191-7.

Couve, A., J. T. Kittler, et al. (2001). "Association of GABA(B) receptors and members of the 14-3-3 family of signaling proteins." Mol Cell Neurosci 17(2): 317-28.

Couve, A., S. Restituito, et al. (2004). "Marlin-1, a novel RNA-binding protein associates with GABA receptors." J Biol Chem 279(14): 13934-43.

Crunelli, V. and N. Leresche (1991). "A role for GABAB receptors in excitation and inhibition of thalamocortical cells." Trends Neurosci 14(1): 16-21.

Cryan, J. F. and K. Kaupmann (2005). "Don't worry 'B' happy! a role for GABA(B) receptors in anxiety and depression." Trends Pharmacol Sci 26(1): 36-43.

Daaka, Y., L. M. Luttrell, et al. (1997). "Switching of the coupling of the beta2adrenergic receptor to different $\mathrm{G}$ proteins by protein kinase A." Nature 390(6655): 88-91.

Dani, V. S., Q. Chang, et al. (2005). "Reduced cortical activity due to a shift in the balance between excitation and inhibition in a mouse model of Rett syndrome." Proc Natl Acad Sci U S A 102(35): 12560-5.

Dascal, N. (2001). "Ion-channel regulation by G proteins." Trends Endocrinol Metab 12(9): 391-8.

Dean, M. K., C. Higgs, et al. (2001). "Dimerization of G-protein-coupled receptors." J Med Chem 44(26): 4595-614.

Delaney, A. J. and P. Sah (1999). "GABA receptors inhibited by benzodiazepines mediate fast inhibitory transmission in the central amygdala." J Neurosci 19(22): 9698-704.

Devreotes, P. N. (1994). "G protein-linked signaling pathways control the developmental program of Dictyostelium." Neuron 12(2): 235-41.

Dohlman, H. G., J. Thorner, et al. (1991). "Model systems for the study of seventransmembrane-segment receptors." Annu Rev Biochem 60: 653-88.

Downes, G. B. and N. Gautam (1999). "The G protein subunit gene families." Genomics 62(3): 544-52.

Drew, C. A., G. A. Johnston, et al. (1984). "Bicuculline-insensitive GABA receptors: studies on the binding of (-)-baclofen to rat cerebellar membranes." Neurosci Lett 52(3): 317-21.

Duman, R. S., E. W. Karbon, et al. (1986). "An examination of the involvement of phospholipases $\mathrm{A} 2$ and $\mathrm{C}$ in the alpha-adrenergic and gamma-aminobutyric 
acid receptor modulation of cyclic AMP accumulation in rat brain slices." $\underline{\mathrm{J}}$ Neurochem 47(3): 800-10.

Duthey, B., S. Caudron, et al. (2002). "A single subunit (GB2) is required for Gprotein activation by the heterodimeric GABA(B) receptor." J Biol Chem 277(5): 3236-41.

Eccles, J. C., R. Schmidt, et al. (1963). "Pharmacological Studies On Presynaptic Inhibition." J Physiol 168: 500-30.

Enna, S. J. (2001). "A GABA(B) mystery: the search for pharmacologically distinct GABA(B) receptors." Mol Interv 1(4): 208-18.

Enz, R. and G. R. Cutting (1999). "GABAC receptor rho subunits are heterogeneously expressed in the human CNS and form homo- and heterooligomers with distinct physical properties." Eur J Neurosci 11(1): 41-50.

Exton, J. H. (1996). "Regulation of phosphoinositide phospholipases by hormones, neurotransmitters, and other agonists linked to G proteins." Annu Rev Pharmacol Toxicol 36: 481-509.

Felder, C. B., R. C. Graul, et al. (1999). "The Venus flytrap of periplasmic binding proteins: an ancient protein module present in multiple drug receptors." $\underline{\text { AAPS }}$ PharmSci 1(2): E2.

Firestein, S. (2000). "The good taste of genomics." Nature 404(6778): 552-3.

Fong, H. K., T. T. Amatruda, 3rd, et al. (1987). "Distinct forms of the beta subunit of GTP-binding regulatory proteins identified by molecular cloning." Proc Natl Acad Sci U S A 84(11): 3792-6.

Franek, M., A. Pagano, et al. (1999). "The heteromeric GABA-B receptor recognizes G-protein alpha subunit C-termini." Neuropharmacology 38(11): 1657-66.

Frang, H., V. M. Mukkala, et al. (2003). "Nonradioactive GTP binding assay to monitor activation of g protein-coupled receptors." Assay Drug Dev Technol 1(2): 275-80.

Fredriksson, R., P. J. Hoglund, et al. (2003). "Seven evolutionarily conserved human rhodopsin G protein-coupled receptors lacking close relatives." FEBS Lett 554(3): 381-8.

Fredriksson, R., M. C. Lagerstrom, et al. (2003). "The G-protein-coupled receptors in the human genome form five main families. Phylogenetic analysis, paralogon groups, and fingerprints." Mol Pharmacol 63(6): 1256-72.

Freson, K., J. Jaeken, et al. (2003). "Functional polymorphisms in the paternally expressed XLalphas and its cofactor ALEX decrease their mutual interaction and enhance receptor-mediated cAMP formation." Hum Mol Genet 12(10): 1121-30. 
Fritschy, J. M. and I. Brunig (2003). "Formation and plasticity of GABAergic synapses: physiological mechanisms and pathophysiological implications." Pharmacol Ther 98(3): 299-323.

Fritschy, J. M., V. Meskenaite, et al. (1999). "GABAB-receptor splice variants GB1a and GB1b in rat brain: developmental regulation, cellular distribution and extrasynaptic localization." Eur J Neurosci 11(3): 761-8.

Fritschy, J. M. and H. Mohler (1995). "GABAA-receptor heterogeneity in the adult rat brain: differential regional and cellular distribution of seven major subunits." J Comp Neurol 359(1): 154-94.

Fritschy, J. M., J. Paysan, et al. (1994). "Switch in the expression of rat GABAAreceptor subtypes during postnatal development: an immunohistochemical study." J Neurosci 14(9): 5302-24.

Froestl, W., B. Bettler, et al. (1999). "Ligands for the isolation of GABA(B) receptors [corrected]." Neuropharmacology 38(11): 1641-6.

Funk, G. D. and J. L. Feldman (1995). "Generation of respiratory rhythm and pattern in mammals: insights from developmental studies." Curr Opin Neurobiol 5(6): 778-85.

Gahwiler, B. H. and D. A. Brown (1985). "GABAB-receptor-activated K+ current in voltage-clamped CA3 pyramidal cells in hippocampal cultures." Proc Natl Acad Sci U S A 82(5): 1558-62.

Gaiarsa, J. L., V. Tseeb, et al. (1995). "Postnatal development of pre- and postsynaptic GABAB-mediated inhibitions in the CA3 hippocampal region of the rat." J Neurophysiol 73(1): 246-55.

Galbiati, F., B. Razani, et al. (2001). "Caveolae and caveolin-3 in muscular dystrophy." Trends Mol Med 7(10): 435-41.

Galvez, T., B. Duthey, et al. (2001). "Allosteric interactions between GB1 and GB2 subunits are required for optimal GABA(B) receptor function." Embo J 20(9): 2152-9.

Galvez, T., M. L. Parmentier, et al. (1999). "Mutagenesis and modeling of the GABAB receptor extracellular domain support a venus flytrap mechanism for ligand binding." J Biol Chem 274(19): 13362-9.

Galvez, T. and J. P. Pin (2003). "[How do G-protein-coupled receptors work? The case of metabotropic glutamate and GABA receptors]." Med Sci (Paris) 19(5): 559-65.

Gambarana, C., C. E. Beattie, et al. (1991). "Region-specific expression of messenger RNAs encoding GABAA receptor subunits in the developing rat brain." Neuroscience 45(2): 423-32. 
Ganguly, K., A. F. Schinder, et al. (2001). "GABA itself promotes the developmental switch of neuronal GABAergic responses from excitation to inhibition." Cell 105(4): 521-32.

Gao, W. J., D. E. Newman, et al. (1999). "Development of inhibitory circuitry in visual and auditory cortex of postnatal ferrets: immunocytochemical localization of GABAergic neurons." J Comp Neurol 409(2): 261-73.

Gao, X. B. and A. N. van den Pol (2001). "GABA, not glutamate, a primary transmitter driving action potentials in developing hypothalamic neurons." $\underline{\mathrm{J}}$ Neurophysiol 85(1): 425-34.

Garthwaite, J. and C. L. Boulton (1995). "Nitric oxide signaling in the central nervous system." Annu Rev Physiol 57: 683-706.

Gautam, N., G. B. Downes, et al. (1998). "The G-protein betagamma complex." $\underline{\text { Cell }}$ Signal 10(7): 447-55.

Gerber, U. and B. H. Gahwiler (1994). "GABAB and adenosine receptors mediate enhancement of the $\mathrm{K}+$ current, IAHP, by reducing adenylyl cyclase activity in rat CA3 hippocampal neurons." J Neurophysiol 72(5): 2360-7.

Gether, U. (2000). "Uncovering molecular mechanisms involved in activation of $\mathrm{G}$ protein-coupled receptors." Endocr Rev 21(1): 90-113.

Gilman, A. G. (1987). "G proteins: transducers of receptor-generated signals." $\underline{\text { Annu }}$ Rev Biochem 56: 615-49.

Greif, G. J., D. L. Sodickson, et al. (2000). "Altered regulation of potassium and calcium channels by GABA(B) and adenosine receptors in hippocampal neurons from mice lacking Galpha(o)." J Neurophysiol 83(2): 1010-8.

Grifa, A., A. Totaro, et al. (1998). "GABA (gamma-amino-butyric acid) neurotransmission: identification and fine mapping of the human GABAB receptor gene." Biochem Biophys Res Commun 250(2): 240-5.

Grunewald, S., B. J. Schupp, et al. (2002). "Importance of the gamma-aminobutyric acid(B) receptor C-termini for G-protein coupling." Mol Pharmacol 61(5): 1070-80.

Gutierrez, A., Z. U. Khan, et al. (1997). "GABAA receptor subunit expression changes in the rat cerebellum and cerebral cortex during aging." Brain Res Mol Brain Res 45(1): 59-70.

Gutierrez, A., Z. U. Khan, et al. (1994). "Age-related decrease of GABAA receptor subunits and glutamic acid decarboxylase in the rat inferior colliculus." J Neurosci 14(12): 7469-77. 
Gutierrez, A., Z. U. Khan, et al. (1996). "Aging-related subunit expression changes of the GABAA receptor in the rat hippocampus." Neuroscience 74(2): 341-8.

Hagberg, B. (2002). "Clinical manifestations and stages of Rett syndrome." Ment Retard Dev Disabil Res Rev 8(2): 61-5.

Hamm, H. E. (1998). "The many faces of G protein signaling." J Biol Chem 273(2): 669-72.

Harayama, N., I. Shibuya, et al. (1998). "Inhibition of N- and P/Q-type calcium channels by postsynaptic $\mathrm{GABAB}$ receptor activation in rat supraoptic neurones." J Physiol 509 (Pt 2): 371-83.

Harrison, C. and J. R. Traynor (2003). "The [35S]GTPgammaS binding assay: approaches and applications in pharmacology." Life Sci 74(4): 489-508.

Harrison, N. L. (1990). "On the presynaptic action of baclofen at inhibitory synapses between cultured rat hippocampal neurones." J Physiol 422: 433-46.

Harrison, N. L., G. D. Lange, et al. (1988). "(-)-Baclofen activates presynaptic GABAB receptors on GABAergic inhibitory neurons from embryonic rat hippocampus." Neurosci Lett 85(1): 105-9.

Harrison, N. L. and M. A. Simmonds (1984). "Modulation of the GABA receptor complex by a steroid anaesthetic." Brain Res 323(2): 287-92.

Hashimoto, T. and K. Kuriyama (1997). "In vivo evidence that GABA(B) receptors are negatively coupled to adenylate cyclase in rat striatum." J Neurochem 69(1): $365-70$.

Havlickova, M., L. Prezeau, et al. (2002). "The intracellular loops of the GB2 subunit are crucial for G-protein coupling of the heteromeric gamma-aminobutyrate B receptor." Mol Pharmacol 62(2): 343-50.

Hawrot, E., Y. Xiao, et al. (1998). "Demonstration of a tandem pair of complement protein modules in GABA(B) receptor 1a." FEBS Lett 432(3): 103-8.

Hayward, B. E. and D. T. Bonthron (2000). "An imprinted antisense transcript at the human GNAS1 locus." Hum Mol Genet 9(5): 835-41.

Herlitze, S., D. E. Garcia, et al. (1996). "Modulation of Ca2+ channels by G-protein beta gamma subunits." Nature 380(6571): 258-62.

Heubach, J. F., U. Ravens, et al. (2004). "Epinephrine activates both Gs and Gi pathways, but norepinephrine activates only the Gs pathway through human beta2-adrenoceptors overexpressed in mouse heart." Mol Pharmacol 65(5): 1313-22.

Heuss, C. and U. Gerber (2000). "G-protein-independent signaling by G-proteincoupled receptors." Trends Neurosci 23(10): 469-75. 
Hevers, W. and H. Luddens (1998). "The diversity of GABAA receptors. Pharmacological and electrophysiological properties of GABAA channel subtypes." Mol Neurobiol 18(1): 35-86.

Hill, D. R. (1985). "GABAB receptor modulation of adenylate cyclase activity in rat brain slices." Br J Pharmacol 84(1): 249-57.

Hill, D. R. and N. G. Bowery (1981). "3H-baclofen and 3H-GABA bind to bicuculline-insensitive GABA B sites in rat brain." Nature 290(5802): 149-52.

Hill, D. R., N. G. Bowery, et al. (1984). "Inhibition of GABAB receptor binding by guanyl nucleotides." J Neurochem 42(3): 652-7.

Hirono, M., T. Yoshioka, et al. (2001). "GABA(B) receptor activation enhances mGluR-mediated responses at cerebellar excitatory synapses." Nat Neurosci 4(12): 1207-16.

Hoon, M. A., E. Adler, et al. (1999). "Putative mammalian taste receptors: a class of taste-specific GPCRs with distinct topographic selectivity." Cell 96(4): 54151.

Horn, F., J. Weare, et al. (1998). "GPCRDB: an information system for G proteincoupled receptors." Nucleic Acids Res 26(1): 275-9.

Hornung, J. P. and J. M. Fritschy (1996). "Developmental profile of GABAAreceptors in the marmoset monkey: expression of distinct subtypes in pre- and postnatal brain." J Comp Neurol 367(3): 413-30.

Houston, D. B. and A. C. Howlett (1998). "Differential receptor-G-protein coupling evoked by dissimilar cannabinoid receptor agonists." Cell Signal 10(9): 66774.

Howard, A. D., G. McAllister, et al. (2001). "Orphan G-protein-coupled receptors and natural ligand discovery." Trends Pharmacol Sci 22(3): 132-40.

Huang, B. O. and D. A. Redburn (1996). "GABA-induced increases in [Ca2+]i in retinal neurons of postnatal rabbits." Vis Neurosci 13(3): 441-7.

Huang, Z. J. (2006). "GABAB receptor isoforms caught in action at the scene." Neuron 50(4): 521-4.

Hubner, C. A., V. Stein, et al. (2001). "Disruption of KCC2 reveals an essential role of K-Cl cotransport already in early synaptic inhibition." Neuron 30(2): 51524.

Ikeda, S. R. and K. Dunlap (1999). "Voltage-dependent modulation of N-type calcium channels: role of G protein subunits." Adv Second Messenger Phosphoprotein Res 33: $131-51$. 
Ishikawa, M., K. Mizukami, et al. (2004). "Immunohistochemical and immunoblot study of $\operatorname{GABA}(\mathrm{A})$ alpha 1 and beta $2 / 3$ subunits in the prefrontal cortex of subjects with schizophrenia and bipolar disorder." Neurosci Res 50(1): 77-84.

Isomoto, S., M. Kaibara, et al. (1998). "Cloning and tissue distribution of novel splice variants of the rat GABAB receptor." Biochem Biophys Res Commun 253(1): $10-5$.

Isomura, Y., M. Sugimoto, et al. (2003). "Synaptically activated Cl- accumulation responsible for depolarizing GABAergic responses in mature hippocampal neurons." J Neurophysiol 90(4): 2752-6.

Ito, T., T. Suzuki, et al. (1996). "Pharmacology of barbiturate tolerance/dependence: GABAA receptors and molecular aspects." Life Sci 59(3): 169-95.

Jakubik, J., L. Bacakova, et al. (1995). "Constitutive activity of the M1-M4 subtypes of muscarinic receptors in transfected CHO cells and of muscarinic receptors in the heart cells revealed by negative antagonists." FEBS Lett 377(2): 275-9.

Jarolimek, W., M. Bijak, et al. (1994). "Differences in the Cs block of baclofen and 4aminopyridine induced potassium currents of guinea pig CA3 neurons in vitro." Synapse 18(3): 169-77.

Jensen, A. A., J. Mosbacher, et al. (2002). "The anticonvulsant gabapentin (neurontin) does not act through gamma-aminobutyric acid-B receptors." Mol Pharmacol 61(6): 1377-84.

Jones, D. T. and R. R. Reed (1987). "Molecular cloning of five GTP-binding protein cDNA species from rat olfactory neuroepithelium." J Biol Chem 262(29): 14241-9.

Jones, K. A., B. Borowsky, et al. (1998). "GABA(B) receptors function as a heteromeric assembly of the subunits GABA(B)R1 and GABA(B)R2." Nature 396(6712): 674-9.

Kajikawa, Y., N. Saitoh, et al. (2001). "GTP-binding protein beta gamma subunits mediate presynaptic calcium current inhibition by GABA(B) receptor." Proc Natl Acad Sci U S A 98(14): 8054-8.

Karbon, E. W., R. S. Duman, et al. (1984). "GABAB receptors and norepinephrinestimulated cAMP production in rat brain cortex." Brain Res 306(1-2): 327-32.

Karbon, E. W. and S. J. Enna (1985). "Characterization of the relationship between gamma-aminobutyric acid B agonists and transmitter-coupled cyclic nucleotide-generating systems in rat brain." Mol Pharmacol 27(1): 53-9.

Kardos, J. (1999). "Recent advances in GABA research." Neurochem Int 34(5): 353 8. 
Katsuki, H. and S. Okuda (1995). "Arachidonic acid as a neurotoxic and neurotrophic substance." Prog Neurobiol 46(6): 607-36.

Kaufmann, W. E., M. V. Johnston, et al. (2005). "MeCP2 expression and function during brain development: implications for Rett syndrome's pathogenesis and clinical evolution." Brain Dev 27 Suppl 1: S77-S87.

Kaufmann, W. E., S. M. MacDonald, et al. (2000). "Dendritic cytoskeletal protein expression in mental retardation: an immunohistochemical study of the neocortex in Rett syndrome." Cereb Cortex 10(10): 992-1004.

Kaupmann, K., K. Huggel, et al. (1997). "Expression cloning of GABA(B) receptors uncovers similarity to metabotropic glutamate receptors." Nature 386(6622): 239-46.

Kaupmann, K., B. Malitschek, et al. (1998). "GABA(B)-receptor subtypes assemble into functional heteromeric complexes." Nature 396(6712): 683-7.

Kaupmann, K., V. Schuler, et al. (1998). "Human gamma-aminobutyric acid type B receptors are differentially expressed and regulate inwardly rectifying $\mathrm{K}+$ channels." Proc Natl Acad Sci U S A 95(25): 14991-6.

Kehlenbach, R. H., J. Matthey, et al. (1994). "XL alpha s is a new type of G protein." Nature 372(6508): 804-9.

Kelly, M. J. and E. J. Wagner (1999). "Estrogen Modulation of G-protein-coupled Receptors." Trends Endocrinol Metab 10(9): 369-374.

Kerr, D. I. and J. Ong (1995). "GABAB receptors." Pharmacol Ther 67(2): 187-246.

Kerr, D. I., J. Ong, et al. (1988). "2-Hydroxy-saclofen: an improved antagonist at central and peripheral GABAB receptors." Neurosci Lett 92(1): 92-6.

Kerr, D. I., J. Ong, et al. (1987). "Phaclofen: a peripheral and central baclofen antagonist." Brain Res 405(1): 150-4.

Killisch, I., C. G. Dotti, et al. (1991). "Expression patterns of GABAA receptor subtypes in developing hippocampal neurons." Neuron 7(6): 927-36.

Kim, M. O., S. Li, et al. (2003). "Early fetal expression of GABA(B1) and $\mathrm{GABA}(\mathrm{B} 2)$ receptor $\mathrm{mRNAs}$ on the development of the rat central nervous system." Brain Res Dev Brain Res 143(1): 47-55.

Kishi, N. and J. D. Macklis (2004). "MECP2 is progressively expressed in postmigratory neurons and is involved in neuronal maturation rather than cell fate decisions." Mol Cell Neurosci 27(3): 306-21.

Kitano, J., K. Kimura, et al. (2002). "Tamalin, a PDZ domain-containing protein, links a protein complex formation of group 1 metabotropic glutamate 
receptors and the guanine nucleotide exchange factor cytohesins." J Neurosci 22(4): 1280-9.

Klausberger, T., I. Sarto, et al. (2001). "Alternate use of distinct intersubunit contacts controls GABAA receptor assembly and stoichiometry." J Neurosci 21(23): 9124-33.

Klemke, M., H. A. Pasolli, et al. (2000). "Characterization of the extra-large G protein alpha-subunit XLalphas. II. Signal transduction properties." J Biol Chem 275(43): 33633-40.

Kniazeff, J., P. P. Saintot, et al. (2004). "Locking the dimeric GABA(B) G-proteincoupled receptor in its active state." J Neurosci 24(2): 370-7.

Knott, C., J. J. Maguire, et al. (1993). "Regional effects of pertussis toxin in vivo and in vitro on GABAB receptor binding in rat brain." Neuroscience 52(1): 73-81.

Kozasa, T., H. Itoh, et al. (1988). "Isolation and characterization of the human Gs alpha gene." Proc Natl Acad Sci U S A 85(7): 2081-5.

Kroeze, W. K., D. J. Sheffler, et al. (2003). "G-protein-coupled receptors at a glance." J Cell Sci 116(Pt 24): 4867-9.

Kubota, H., S. Katsurabayashi, et al. (2003). "GABAB receptor transduction mechanisms, and cross-talk between protein kinases A and C, in GABAergic terminals synapsing onto neurons of the rat nucleus basalis of Meynert." $\underline{\mathrm{J}}$ Physiol 551(Pt 1): 263-76.

Kuner, R., G. Kohr, et al. (1999). "Role of heteromer formation in GABAB receptor function." Science 283(5398): 74-7.

Kunishima, N., Y. Shimada, et al. (2000). "Structural basis of glutamate recognition by a dimeric metabotropic glutamate receptor." Nature 407(6807): 971-7.

Kurose, H. (2003). "Galpha12 and Galpha13 as key regulatory mediator in signal transduction." Life Sci 74(2-3): 155-61.

Labrecque, J., V. Anastassov, et al. (2005). "The development of an europium-GTP assay to quantitate chemokine antagonist interactions for CXCR4 and CCR5." Assay Drug Dev Technol 3(6): 637-48.

Lambright, D. G., J. Sondek, et al. (1996). "The 2.0 A crystal structure of a heterotrimeric G protein." Nature 379(6563): 311-9.

Lanneau, C., A. Green, et al. (2001). "Gabapentin is not a GABAB receptor agonist." Neuropharmacology 41(8): 965-75.

Laugwitz, K. L., A. Allgeier, et al. (1996). "The human thyrotropin receptor: a heptahelical receptor capable of stimulating members of all four $\mathrm{G}$ protein families." Proc Natl Acad Sci U S A 93(1): 116-20. 
Laurie, D. J., P. H. Seeburg, et al. (1992). "The distribution of 13 GABAA receptor subunit mRNAs in the rat brain. II. Olfactory bulb and cerebellum." J Neurosci 12(3): 1063-76.

Laurie, D. J., W. Wisden, et al. (1992). "The distribution of thirteen GABAA receptor subunit mRNAs in the rat brain. III. Embryonic and postnatal development." J Neurosci 12(11): 4151-72.

Lee, D. K., S. R. George, et al. (2001). "Orphan G protein-coupled receptors in the CNS." Curr Opin Pharmacol 1(1): 31-9.

Leeb-Lundberg, L. M., S. A. Mathis, et al. (1994). "Antagonists of bradykinin that stabilize a G-protein-uncoupled state of the B2 receptor act as inverse agonists in rat myometrial cells." J Biol Chem 269(42): 25970-3.

Lefkowitz, R. J., S. Cotecchia, et al. (1993). "Constitutive activity of receptors coupled to guanine nucleotide regulatory proteins." Trends Pharmacol Sci 14(8): 303-7.

Leitch, E., J. Coaker, et al. (2005). "GABA type-A activity controls its own developmental polarity switch in the maturing retina." J Neurosci 25(19): 4801-5.

Liang, F., Y. Hatanaka, et al. (2000). "Differential expression of gamma-aminobutyric acid type B receptor- $1 \mathrm{a}$ and $-1 \mathrm{~b}$ mRNA variants in GABA and nonGABAergic neurons of the rat brain." J Comp Neurol 416(4): 475-95.

Liebmann, C. and F. D. Bohmer (2000). "Signal transduction pathways of G proteincoupled receptors and their cross-talk with receptor tyrosine kinases: lessons from bradykinin signaling." Curr Med Chem 7(9): 911-43.

Liebmann, C., A. Graness, et al. (1995). "The adenylate cyclase-inhibiting bradykinin receptor in guinea pig ileum membranes exhibits an unique antagonist profile." Eur J Pharmacol 289(2): 403-7.

Lin, M. H., M. P. Takahashi, et al. (1994). "Intracellular calcium increase induced by GABA in visual cortex of fetal and neonatal rats and its disappearance with development." Neurosci Res 20(1): 85-94.

Liu, J., D. Maurel, et al. (2004). "Molecular determinants involved in the allosteric control of agonist affinity in the GABAB receptor by the GABAB2 subunit." $\mathrm{J}$ Biol Chem 279(16): 15824-30.

Liu, J., S. Yu, et al. (2000). "Identification of a methylation imprint mark within the mouse Gnas locus." Mol Cell Biol 20(16): 5808-17.

Liu, Q. and M. T. Wong-Riley (2006). "Developmental changes in the expression of GABAA receptor subunits alpha1, alpha2, and alpha3 in brain stem nuclei of rats." Brain Res 1098(1): 129-38. 
Lopez-Bendito, G., R. Lujan, et al. (2003). "Blockade of GABA(B) receptors alters the tangential migration of cortical neurons." Cereb Cortex 13(9): 932-42.

Lopez-Bendito, G., R. Shigemoto, et al. (2002). "Expression and distribution of metabotropic GABA receptor subtypes GABABR1 and GABABR2 during rat neocortical development." Eur J Neurosci 15(11): 1766-78.

Lopez-Tellez, J. F., J. Vela, et al. (2004). "Postnatal development of the alpha1 containing GABAA receptor subunit in rat hippocampus." Brain Res Dev Brain Res 148(1): 129-41.

Luhmann, H. J. and D. A. Prince (1991). "Postnatal maturation of the GABAergic system in rat neocortex." J Neurophysiol 65(2): 247-63.

Lujan, R., R. Shigemoto, et al. (2005). "Glutamate and GABA receptor signalling in the developing brain." Neuroscience 130(3): 567-80.

Luscher, B. and C. A. Keller (2004). "Regulation of GABAA receptor trafficking, channel activity, and functional plasticity of inhibitory synapses." Pharmacol Ther 102(3): 195-221.

Luscher, C., L. Y. Jan, et al. (1997). "G protein-coupled inwardly rectifying K+ channels (GIRKs) mediate postsynaptic but not presynaptic transmitter actions in hippocampal neurons." Neuron 19(3): 687-95.

MacLennan, A. J., N. Brecha, et al. (1991). "Independent cellular and ontogenetic expression of mRNAs encoding three alpha polypeptides of the rat GABAA receptor." Neuroscience 43(2-3): 369-80.

Maguire, G., B. Maple, et al. (1989). "Gamma-aminobutyrate type B receptor modulation of L-type calcium channel current at bipolar cell terminals in the retina of the tiger salamander." Proc Natl Acad Sci U S A 86(24): 10144-7.

Malitschek, B., D. Ruegg, et al. (1998). "Developmental changes of agonist affinity at GABABR1 receptor variants in rat brain." Mol Cell Neurosci 12(1-2): 56-64.

Marchetti, C., S. Pagnotta, et al. (2002). "Inhibition of spinal or hypoglossal motoneurons of the newborn rat by glycine or GABA." Eur J Neurosci 15(6): 975-83.

Margeta-Mitrovic, M., Y. N. Jan, et al. (2000). "A trafficking checkpoint controls GABA(B) receptor heterodimerization." Neuron 27(1): 97-106.

Margeta-Mitrovic, M., Y. N. Jan, et al. (2001). "Function of GB1 and GB2 subunits in G protein coupling of GABA(B) receptors." Proc Natl Acad Sci U S A 98(25): 14649-54. 
Margeta-Mitrovic, M., Y. N. Jan, et al. (2001). "Ligand-induced signal transduction within heterodimeric GABA(B) receptor." Proc Natl Acad Sci U S A 98(25): 14643-8.

Maric, D., Q. Y. Liu, et al. (2001). "GABA expression dominates neuronal lineage progression in the embryonic rat neocortex and facilitates neurite outgrowth via GABA(A) autoreceptor/Cl- channels." J Neurosci 21(7): 2343-60.

Markby, D. W., R. Onrust, et al. (1993). "Separate GTP binding and GTPase activating domains of a G alpha subunit." Science 262(5141): 1895-901.

Marshall, F. H., K. A. Jones, et al. (1999). "GABAB receptors - the first 7TM heterodimers." Trends Pharmacol Sci 20(10): 396-9.

Martin, S. C., S. J. Russek, et al. (1999). "Molecular identification of the human GABABR2: cell surface expression and coupling to adenylyl cyclase in the absence of GABABR1." Mol Cell Neurosci 13(3): 180-91.

Martin, S. C., S. J. Russek, et al. (2001). "Human GABA(B)R genomic structure: evidence for splice variants in GABA(B)R1 but not GABA(B)R2." Gene 278(1-2): 63-79.

Marty, S., B. Berninger, et al. (1996). "GABAergic stimulation regulates the phenotype of hippocampal interneurons through the regulation of brainderived neurotrophic factor." Neuron 16(3): 565-70.

Masu, M., Y. Tanabe, et al. (1991). "Sequence and expression of a metabotropic glutamate receptor." Nature 349(6312): 760-5.

Matsushima, T., J. Tegner, et al. (1993). "GABAB receptor activation causes a depression of low- and high-voltage-activated $\mathrm{Ca} 2+$ currents, postinhibitory rebound, and postspike afterhyperpolarization in lamprey neurons." J Neurophysiol 70(6): 2606-19.

McFarlane-Anderson, N., J. Bailly, et al. (1992). "Levels of G-proteins in liver and brain of lean and obese (ob/ob) mice." Biochem J 282 (Pt 1): 15-23.

Mehta, A. K. and M. K. Ticku (1999). "An update on GABAA receptors." Brain Res Brain Res Rev 29(2-3): 196-217.

Menon-Johansson, A. S., N. Berrow, et al. (1993). "G(o) transduces GABAB-receptor modulation of $\mathrm{N}$-type calcium channels in cultured dorsal root ganglion neurons." Pflugers Arch 425(3-4): 335-43.

Michelson, H. B. and R. K. Wong (1991). "Excitatory synaptic responses mediated by GABAA receptors in the hippocampus." Science 253(5026): 1420-3.

Miczek, K. A., E. W. Fish, et al. (2003). "Neurosteroids, GABAA receptors, and escalated aggressive behavior." Horm Behav 44(3): 242-57. 
Milligan, G., F. M. Mitchell, et al. (1990). "The role and specificity of guanine nucleotide binding proteins in receptor-effector coupling." Symp Soc Exp Biol 44: 157-72.

Milligan, G. and J. H. White (2001). "Protein-protein interactions at G-proteincoupled receptors." Trends Pharmacol Sci 22(10): 513-8.

Mintz, I. M. and B. P. Bean (1993). "GABAB receptor inhibition of P-type Ca2+ channels in central neurons." Neuron 10(5): 889-98.

Misgeld, U., M. Bijak, et al. (1995). "A physiological role for GABAB receptors and the effects of baclofen in the mammalian central nervous system." Prog Neurobiol 46(4): 423-62.

Mohler, H., D. Benke, et al. (2001). "GABA(B)-receptor isoforms molecular architecture and distribution." Life Sci 68(19-20): 2297-300.

Mohler, H. and J. M. Fritschy (1999). "GABAB receptors make it to the top--as dimers." Trends Pharmacol Sci 20(3): 87-9.

Moretti, P., J. M. Levenson, et al. (2006). "Learning and memory and synaptic plasticity are impaired in a mouse model of Rett syndrome." J Neurosci 26(1): 319-27.

Morishita, R., K. Kato, et al. (1990). "GABAB receptors couple to G proteins Go, Go* and Gi1 but not to Gi2." FEBS Lett 271(1-2): 231-5.

Morton, R. A., N. A. Manuel, et al. (2001). "Regulation of muscarinic acetylcholine receptor-mediated synaptic responses by GABA(B) receptors in the rat hippocampus." J Physiol 535(Pt 3): 757-66.

Murthy, K. S., H. Zhou, et al. (2004). "Activation of PLC-delta1 by Gi/o-coupled receptor agonists." Am J Physiol Cell Physiol 287(6): C1679-87.

Namba, T., Y. Sugimoto, et al. (1993). "Alternative splicing of C-terminal tail of prostaglandin E receptor subtype EP3 determines G-protein specificity." Nature 365(6442): 166-70.

Nehring, R. B., H. P. Horikawa, et al. (2000). "The metabotropic GABAB receptor directly interacts with the activating transcription factor 4." J Biol Chem 275(45): 35185-91.

Neves, S. R., P. T. Ram, et al. (2002). "G protein pathways." Science 296(5573): 1636-9.

New, D. C. and J. T. Wong (1998). "The evidence for G-protein-coupled receptors and heterotrimeric $\mathrm{G}$ proteins in protozoa and ancestral metazoa." Biol Signals Recept 7(2): 98-108. 
Newberry, N. R. and R. A. Nicoll (1984). "Direct hyperpolarizing action of baclofen on hippocampal pyramidal cells." Nature 308(5958): 450-2.

Ng, G. Y., S. Bertrand, et al. (2001). "Gamma-aminobutyric acid type B receptors with specific heterodimer composition and postsynaptic actions in hippocampal neurons are targets of anticonvulsant gabapentin action." $\underline{\mathrm{Mol}}$ Pharmacol 59(1): 144-52.

Ng, G. Y., J. Clark, et al. (1999). "Identification of a GABAB receptor subunit, gb2, required for functional GABAB receptor activity." J Biol Chem 274(12): 7607-10.

Nishikawa, M., M. Hirouchi, et al. (1997). "Functional coupling of Gi subtype with GABAB receptor/adenylyl cyclase system: analysis using a reconstituted system with purified GTP-binding protein from bovine cerebral cortex." Neurochem Int 31(1): 21-5.

Nishimaru, H., M. Iizuka, et al. (1996). "Spontaneous motoneuronal activity mediated by glycine and GABA in the spinal cord of rat fetuses in vitro." J Physiol 497 (Pt 1): 131-43.

Novotny, J. and P. Svoboda (1998). "The long (Gs(alpha)-L) and short (Gs(alpha)-S) variants of the stimulatory guanine nucleotide-binding protein. Do they behave in an identical way?" J Mol Endocrinol 20(2): 163-73.

Obata, K., M. Oide, et al. (1978). "Excitatory and inhibitory actions of GABA and glycine on embryonic chick spinal neurons in culture." Brain Res 144(1): 17984.

Offermanns, S., E. Heiler, et al. (1994). "Gq and G11 are concurrently activated by bombesin and vasopressin in Swiss 3 T3 cells." FEBS Lett 349(2): 201-4.

Olianas, M. C. and P. Onali (1993). "Synergistic interaction of muscarinic and opioid receptors with GS-linked neurotransmitter receptors to stimulate adenylyl cyclase activity of rat olfactory bulb." J Neurochem 61(6): 2183-90.

Olianas, M. C. and P. Onali (1999). "GABA(B) receptor-mediated stimulation of adenylyl cyclase activity in membranes of rat olfactory bulb." $\mathrm{Br}$ J Pharmacol 126(3): 657-64.

Orry, A. J. and B. A. Wallace (2000). "Modeling and docking the endothelin Gprotein-coupled receptor." Biophys J 79(6): 3083-94.

Owens, D. F., L. H. Boyce, et al. (1996). "Excitatory GABA responses in embryonic and neonatal cortical slices demonstrated by gramicidin perforated-patch recordings and calcium imaging." J Neurosci 16(20): 6414-23.

Owens, D. F. and A. R. Kriegstein (2002). "Is there more to GABA than synaptic inhibition?" Nat Rev Neurosci 3(9): 715-27. 
Pagano, A., G. Rovelli, et al. (2001). "C-terminal interaction is essential for surface trafficking but not for heteromeric assembly of GABA(b) receptors." $\underline{\mathrm{J}}$ Neurosci 21(4): 1189-202.

Palczewski, K., T. Kumasaka, et al. (2000). "Crystal structure of rhodopsin: A G protein-coupled receptor." Science 289(5480): 739-45.

Panzanelli, P., G. Lopez-Bendito, et al. (2004). "Localization and developmental expression of GABA(B) receptors in the rat olfactory bulb." J Neurocytol 33(1): 87-99.

Pasolli, H. A. and W. B. Huttner (2001). "Expression of the extra-large G protein alpha-subunit XLalphas in neuroepithelial cells and young neurons during development of the rat nervous system." Neurosci Lett 301(2): 119-22.

Pasolli, H. A., M. Klemke, et al. (2000). "Characterization of the extra-large G protein alpha-subunit XLalphas. I. Tissue distribution and subcellular localization." J Biol Chem 275(43): 33622-32.

Payne, J. A., C. Rivera, et al. (2003). "Cation-chloride co-transporters in neuronal communication, development and trauma." Trends Neurosci 26(4): 199-206.

Perez-Garci, E., M. Gassmann, et al. (2006). "The GABAB1b isoform mediates longlasting inhibition of dendritic $\mathrm{Ca} 2+$ spikes in layer 5 somatosensory pyramidal neurons." Neuron 50(4): 603-16.

Pfaff, T., B. Malitschek, et al. (1999). "Alternative splicing generates a novel isoform of the rat metabotropic GABA(B)R1 receptor." Eur J Neurosci 11(8): 287482.

Pin, J. P. (1998). "Synaptic transmission. The two faces of glutamate." Nature 394(6688): 19-21.

Pirker, S., C. Schwarzer, et al. (2000). "GABA(A) receptors: immunocytochemical distribution of 13 subunits in the adult rat brain." Neuroscience 101(4): 81550.

Plagge, A., E. Gordon, et al. (2004). "The imprinted signaling protein XL alpha s is required for postnatal adaptation to feeding." Nat Genet 36(8): 818-26.

Plakidou-Dymock, S., D. Dymock, et al. (1998). "A higher plant seventransmembrane receptor that influences sensitivity to cytokinins." Curr Biol 8(6): 315-24.

Poncer, J. C., R. A. McKinney, et al. (1997). "Either N- or P-type calcium channels mediate GABA release at distinct hippocampal inhibitory synapses." 18(3): 463-72. 
Poorkhalkali, N., K. Juneblad, et al. (2000). "Immunocytochemical distribution of the $\mathrm{GABA}(\mathrm{B})$ receptor splice variants $\mathrm{GABA}(\mathrm{B}) \mathrm{R} 1 \mathrm{a}$ and $\mathrm{R} 1 \mathrm{~b}$ in the rat $\mathrm{CNS}$ and dorsal root ganglia." Anat Embryol (Berl) 201(1): 1-13.

Porter, B. E., G. Zhang, et al. (2005). "Heterogeneous GABAA receptor subunit expression in pediatric epilepsy patients." Neurobiol Dis 18(3): 484-91.

Pronin, A. N. and N. Gautam (1992). "Interaction between G-protein beta and gamma subunit types is selective." Proc Natl Acad Sci U S A 89(13): 6220-4.

Ramirez, J. M. and D. W. Richter (1996). "The neuronal mechanisms of respiratory rhythm generation." Curr Opin Neurobiol 6(6): 817-25.

Raymond, J. R., Y. V. Mukhin, et al. (1999). "The recombinant 5-HT1A receptor: G protein coupling and signalling pathways." Br J Pharmacol 127(8): 1751-64.

Reichling, D. B., A. Kyrozis, et al. (1994). "Mechanisms of GABA and glycine depolarization-induced calcium transients in rat dorsal horn neurons." J Physiol 476(3): 411-21.

Reithmann, C., P. Gierschik, et al. (1990). "Stimulation and inhibition of adenylyl cyclase." Symp Soc Exp Biol 44: 207-24.

Rekling, J. C. and J. L. Feldman (1998). "PreBotzinger complex and pacemaker neurons: hypothesized site and kernel for respiratory rhythm generation." Annu Rev Physiol 60: 385-405.

Remmers, A. E., C. Engel, et al. (1999). "Interdomain interactions regulate GDP release from heterotrimeric G proteins." Biochemistry 38(42): 13795-800.

Ritter, B. and W. Zhang (2000). "Early postnatal maturation of GABAA-mediated inhibition in the brainstem respiratory rhythm-generating network of the mouse." Eur J Neurosci 12(8): 2975-84.

Ritter, B., J. Zschuntsch, et al. (2004). "The GABA(B) receptor subunits R1 and R2 interact differentially with the activation transcription factor ATF4 in mouse brain during the postnatal development." Brain Res Dev Brain Res 149(1): 737.

Rivera, C., J. Voipio, et al. (1999). "The K+/Cl- co-transporter KCC2 renders GABA hyperpolarizing during neuronal maturation." Nature 397(6716): 251-5.

Robbins, M. J., A. R. Calver, et al. (2001). "GABA(B2) is essential for g-protein coupling of the GABA(B) receptor heterodimer." J Neurosci 21(20): 8043-52.

Roberts, E. and S. Frankel (1950). "gamma-Aminobutyric acid in brain: its formation from glutamic acid." J Biol Chem 187(1): 55-63. 
Ruano, D., F. Araujo, et al. (2000). "GABAA and alpha-amino-3-hydroxy-5methylsoxazole-4-propionate receptors are differentially affected by aging in the rat hippocampus." J Biol Chem 275(26): 19585-93.

Rudolph, U., F. Crestani, et al. (1999). "Benzodiazepine actions mediated by specific gamma-aminobutyric acid(A) receptor subtypes." Nature 401(6755): 796-800.

Rudolph, U. and H. Mohler (2004). "Analysis of GABAA receptor function and dissection of the pharmacology of benzodiazepines and general anesthetics through mouse genetics." Annu Rev Pharmacol Toxicol 44: 475-98.

Ryba, N. J. and R. Tirindelli (1997). "A new multigene family of putative pheromone receptors." Neuron 19(2): 371-9.

Saint, D. A., T. Thomas, et al. (1990). "GABAB agonists modulate a transient potassium current in cultured mammalian hippocampal neurons." Neurosci Lett 118(1): 9-13.

Sakaba, T. and E. Neher (2003). "Direct modulation of synaptic vesicle priming by GABA(B) receptor activation at a glutamatergic synapse." Nature 424(6950): $775-8$.

Sauter, K., T. Grampp, et al. (2005). "Subtype-selective interaction with the transcription factor CCAAT/enhancer-binding protein (C/EBP) homologous protein (CHOP) regulates cell surface expression of GABA(B) receptors." $\underline{\mathrm{J}}$ Biol Chem 280(39): 33566-72.

Schaad, N. C., M. Schorderet, et al. (1989). "Accumulation of cyclic AMP elicited by vasoactive intestinal peptide is potentiated by noradrenaline, histamine, adenosine, baclofen, phorbol esters, and ouabain in mouse cerebral cortical slices: studies on the role of arachidonic acid metabolites and protein kinase C." J Neurochem 53(6): 1941-51.

Schofield, P. R., M. G. Darlison, et al. (1987). "Sequence and functional expression of the GABA A receptor shows a ligand-gated receptor super-family." Nature 328(6127): 221-7.

Schuler, V., C. Luscher, et al. (2001). "Epilepsy, hyperalgesia, impaired memory, and loss of pre- and postsynaptic GABA(B) responses in mice lacking GABA(B(1))." Neuron 31(1): 47-58.

Schwartz, T. W. and M. M. Rosenkilde (1996). "Is there a 'lock' for all agonist 'keys' in 7TM receptors?" Trends Pharmacol Sci 17(6): 213-6.

Schwarz, D. A., G. Barry, et al. (2000). "Characterization of gamma-aminobutyric acid receptor GABAB(1e), a GABAB(1) splice variant encoding a truncated receptor." J Biol Chem 275(41): 32174-81. 
Scott, R. H. and A. C. Dolphin (1986). "Regulation of calcium currents by a GTP analogue: potentiation of (-)-baclofen-mediated inhibition." Neurosci Lett 69(1): 59-64.

Seifert, R., K. Wenzel-Seifert, et al. (1998). "Different effects of Gsalpha splice variants on beta2-adrenoreceptor-mediated signaling. The Beta2adrenoreceptor coupled to the long splice variant of Gsalpha has properties of a constitutively active receptor." J Biol Chem 273(18): 5109-16.

Serafini, R., A. Y. Valeyev, et al. (1995). "Depolarizing GABA-activated Clchannels in embryonic rat spinal and olfactory bulb cells." J Physiol 488 (Pt 2): $371-86$.

Shahbazian, M. D. and H. Y. Zoghbi (2002). "Rett syndrome and MeCP2: linking epigenetics and neuronal function." Am J Hum Genet 71(6): 1259-72.

Shen, W. and M. M. Slaughter (1999). "Metabotropic GABA receptors facilitate Ltype and inhibit N-type calcium channels in single salamander retinal neurons." J Physiol 516 (Pt 3): 711-8.

Sieghart, W. (2000). "Unraveling the function of GABA(A) receptor subtypes." Trends Pharmacol Sci 21(11): 411-3.

Simonds, W. F. (1999). "G protein regulation of adenylate cyclase." Trends Pharmacol Sci 20(2): 66-73.

Sivilotti, L. and A. Nistri (1991). "GABA receptor mechanisms in the central nervous system." Prog Neurobiol 36(1): 35-92.

Smith, J. C., H. H. Ellenberger, et al. (1991). "Pre-Botzinger complex: a brainstem region that may generate respiratory rhythm in mammals." Science 254(5032): 726-9.

Sondek, J., A. Bohm, et al. (1996). "Crystal structure of a G-protein beta gamma dimer at 2.1A resolution." Nature 379(6563): 369-74.

Sprang, S. R. (1997). "G protein mechanisms: insights from structural analysis." Annu Rev Biochem 66: 639-78.

Steiger, J. L., S. Bandyopadhyay, et al. (2004). "cAMP response element-binding protein, activating transcription factor- 4 , and upstream stimulatory factor differentially control hippocampal GABABR1a and GABABR1b subunit gene expression through alternative promoters." J Neurosci 24(27): 6115-26.

Strathmann, M. and M. I. Simon (1990). "G protein diversity: a distinct class of alpha subunits is present in vertebrates and invertebrates." Proc Natl Acad Sci U S A 87(23): 9113-7. 
Takahashi, T., Y. Kajikawa, et al. (1998). "G-Protein-coupled modulation of presynaptic calcium currents and transmitter release by a GABAB receptor." $\underline{\mathrm{J}}$ Neurosci 18(9): 3138-46.

Takayama, C. and Y. Inoue (2004). "GABAergic signaling in the developing cerebellum." Anat Sci Int 79(3): 124-36.

Tang, W. J. and A. G. Gilman (1992). "Adenylyl cyclases." Cell 70(6): 869-72.

Thompson, S. M. and B. H. Gahwiler (1992). "Comparison of the actions of baclofen at pre- and postsynaptic receptors in the rat hippocampus in vitro." J Physiol 451: 329-45.

Tilly, B. C., P. A. van Paridon, et al. (1987). "Inositol phosphate metabolism in bradykinin-stimulated human A431 carcinoma cells. Relationship to calcium signalling." Biochem J 244(1): 129-35.

Tropea, M. M., C. M. Munoz, et al. (1992). "Bradykinin binding to B2 kinin receptors and stimulation of phosphoinositide turnover and arachidonic acid release in primary cultures of cells from late pregnant rat myometrium." Can J Physiol Pharmacol 70(10): 1360-71.

Uezono, Y., M. Kanaide, et al. (2005). "Coupling of the GABAB receptor GABAB2 subunit to $G$ proteins: Evidence from the Xenopus oocyte and baby kidney hamster cell expression system." Am J Physiol Cell Physiol.

Ulloa-Aguirre, A., D. Stanislaus, et al. (1999). "Structure-activity relationships of G protein-coupled receptors." Arch Med Res 30(6): 420-35.

Urwyler, S., J. Mosbacher, et al. (2001). "Positive allosteric modulation of native and recombinant gamma-aminobutyric acid(B) receptors by 2,6-Di-tert-butyl-4-(3hydroxy-2,2-dimethyl-propyl)-phenol (CGP7930) and its aldehyde analog CGP13501." Mol Pharmacol 60(5): 963-71.

Vardi, N., L. L. Zhang, et al. (2000). "Evidence that different cation chloride cotransporters in retinal neurons allow opposite responses to GABA." $\underline{\mathrm{J}}$ Neurosci 20(20): 7657-63.

Varju, P., Z. Katarova, et al. (2001). "GABA signalling during development: new data and old questions." Cell Tissue Res 305(2): 239-46.

Vernier, P., B. Cardinaud, et al. (1995). "An evolutionary view of drug-receptor interaction: the bioamine receptor family." Trends Pharmacol Sci 16(11): 37581.

Vernon, E., G. Meyer, et al. (2001). "GABA(B) receptors couple directly to the transcription factor ATF4." Mol Cell Neurosci 17(4): 637-45.

Watts, V. J. and K. A. Neve (2005). "Sensitization of adenylate cyclase by Galpha i/ocoupled receptors." Pharmacol Ther 106(3): 405-21. 
Wegelius, K., M. Pasternack, et al. (1998). "Distribution of GABA receptor rho subunit transcripts in the rat brain." Eur J Neurosci 10(1): 350-7.

Wei, K., Z. Jia, et al. (2001). "Cloning and characterization of a novel variant of rat GABA(B)R1 with a truncated C-terminus." Brain Res Mol Brain Res 89(1-2): 103-10.

Wei, W., N. Zhang, et al. (2003). "Perisynaptic localization of delta subunitcontaining $\mathrm{GABA}(\mathrm{A})$ receptors and their activation by GABA spillover in the mouse dentate gyrus." J Neurosci 23(33): 10650-61.

Weinstein, L. S., S. Yu, et al. (2001). "Endocrine manifestations of stimulatory G protein alpha-subunit mutations and the role of genomic imprinting." Endocr Rev 22(5): 675-705.

Wess, J. (1997). "G-protein-coupled receptors: molecular mechanisms involved in receptor activation and selectivity of G-protein recognition." Faseb J 11(5): 346-54.

White, J. H., R. A. McIllhinney, et al. (2000). "The GABAB receptor interacts directly with the related transcription factors CREB2 and ATFx." Proc Natl Acad Sci U S A 97(25): 13967-72.

White, J. H., A. Wise, et al. (1998). "Heterodimerization is required for the formation of a functional GABA(B) receptor." Nature 396(6712): 679-82.

Williamson, C. M., M. D. Turner, et al. (2006). "Identification of an imprinting control region affecting the expression of all transcripts in the Gnas cluster." Nat Genet 38(3): 350-5.

Wisden, W., D. J. Laurie, et al. (1992). "The distribution of 13 GABAA receptor subunit mRNAs in the rat brain. I. Telencephalon, diencephalon, mesencephalon." J Neurosci 12(3): 1040-62.

Wojcik, W. J. and N. H. Neff (1984). "gamma-aminobutyric acid B receptors are negatively coupled to adenylate cyclase in brain, and in the cerebellum these receptors may be associated with granule cells." Mol Pharmacol 25(1): 24-8.

Wu, L. G. and P. Saggau (1997). "Presynaptic inhibition of elicited neurotransmitter release." Trends Neurosci 20(5): 204-12.

Wu, W. L., L. Ziskind-Conhaim, et al. (1992). "Early development of glycine- and GABA-mediated synapses in rat spinal cord." J Neurosci 12(10): 3935-45.

Xie, T., A. Plagge, et al. (2006). "The alternative stimulatory G protein alpha-subunit XLalphas is a critical regulator of energy and glucose metabolism and sympathetic nerve activity in adult mice." J Biol Chem 281(28): 18989-99. 
Xu, J. and W. J. Wojcik (1986). "Gamma aminobutyric acid B receptor-mediated inhibition of adenylate cyclase in cultured cerebellar granule cells: blockade by islet-activating protein." J Pharmacol Exp Ther 239(2): 568-73.

Yamada, J., F. Saitow, et al. (1999). "GABA(B) receptor-mediated presynaptic inhibition of glutamatergic and GABAergic transmission in the basolateral amygdala." Neuropharmacology 38(11): 1743-53.

Yu, Z. Y., W. Wang, et al. (2006). "Changes in neocortical and hippocampal GABAA receptor subunit distribution during brain maturation and aging." Brain Res 1099(1): 73-81.

Zamponi, G. W. (2001). "Determinants of G protein inhibition of presynaptic calcium channels." Cell Biochem Biophys 34(1): 79-94.

Zhang, W., F. Elsen, et al. (1999). "Postnatal development of GABAB receptormediated modulation of voltage-activated $\mathrm{Ca} 2+$ currents in mouse brain-stem neurons." Eur J Neurosci 11(7): 2332-42.

Zoghbi, H. Y. (2005). "MeCP2 dysfunction in humans and mice." J Child Neurol 20(9): 736-40. 